MARYJA JEST PIĘKNA 
ANDRZEJ A. NAPIÓRKOWSKI OSPPE

\section{MARYJA JEST PIĘKNA ZARYS MARIOLOGII I MARYJNOŚCI}


Recenzja wydawnicza:

ks. dr hab. Janusz Lekan, prof. KUL

Korekta

Agnieszka Caba, Anna Niklewicz

Skład i łamanie

Pracownia Wydawnicza AD verbum

Okładka

Artur Falkowski

Publikacja finansowana $\mathrm{z}$ dotacji na utrzymanie potencjału badawczego Uniwersytetu Papieskiego Jana Pawła II w Krakowie przyznanej przez Ministra Nauki i Szkolnictwa Wyższego w roku 2016.

Copyright (C 2016 by Uniwersytet Papieski Jana Pawła II w Krakowie

ISBN 978-83-7438-537-4 (wersja drukowana)

ISBN 978-83-7438-538-1 (wersja online)

DOI: http://dx.doi.org/10.15633/9788374385381

Uniwersytet Papieski Jana Pawła II w Krakowie

Wydawnictwo Naukowe

30-348 Kraków, ul. Bobrzyńskiego 10

tel./faks: 124226040

e-mail: wydawnictwo@upjp2.edu.pl 


\section{$\mathrm{Ku}$ integralnej mariologii}

\subsection{Kim jest Maryja?}

„Kimże jest ta, która świeci z wysoka jak zorza, piękna jak księżyc, jaśniejąca jak słońce, groźna jak zbrojne zastępy?” (Pnp 6, 10). Wbrew pozorom trudno odpowiedzieć na to pytanie. Oczywiście jako chrześcijanie mamy do dyspozycji treści objawienia, zawarte w Piśmie Świętym i Tradycji, oraz ponad dwa tysiące lat modlitwy, intelektualnej refleksji i asystencji Ducha Świętego w zgłębianiu tych przekazów w rzeczywistości Kościoła. Wiemy, że Maryja jest Matką Jezusa z Nazaretu, który okazał się Mesjaszem, czyli prawdziwym i jedynym Odkupicielem wszystkich ludzi i całego świata. Wierzymy, że ukazuje nam Ona wciąż na nowo Chrystusa, przewodzi nam we wspólnocie wiary, prowadzi nas do Niego i jako Wniebowzięta za nami się wstawia i oręduje.

W Liście do Rzymian odnajdujemy zachętę: „A zwłaszcza rozumiejcie chwilę obecną: teraz nadeszła dla was godzina powstania ze snu. Teraz bowiem zbawienie jest bliżej nas niż wtedy, gdyśmy uwierzyli. Noc się posunęła, a przybliżył się dzień. Odrzućmy więc uczynki ciemności, a przyobleczmy się w zbroję światła!” (Rz 13, 11-12). Rzeczywistość zbawienia, wysłużona przez śmierć i zmartwychwstanie Jezusa Chrystusa, jest nam udzielana w Kościele, gdzie skutecznie w mocy Ducha Świętego pomaga nam Maryja, jako Matka naszego Pana, Matka Kościoła i Matka nasza zgodnie z testamentem Jezusa z krzyża (por. J 19, 25-27).

„Potem wielki znak się ukazał na niebie: Niewiasta obleczona w słońce i księżyc pod jej stopami, a na jej głowie wieniec z gwiazd dwunastu. A jest brzemienna. I woła, cierpiąc bóle i męki rodzenia. I inny znak się ukazał 
na niebie: Oto wielki Smok barwy ognia, mający siedem głów i dziesięć rogów - a na głowach jego siedem diademów. I ogon jego zmiata trzecią część gwiazd nieba: i rzucił je na ziemię. I stanął Smok przed mającą rodzić Niewiastą, ażeby skoro porodzi, pożreć jej dziecię. I porodziła Syna - Mężczyznę [...]. I zostało porwane jej Dziecię do Boga i do Jego tronu” (Ap 12, 1-5). W tym zrodzonym mężczyźnie w sposób symboliczny możemy się odnaleźć i my. Maryja bowiem jako Matka Kościoła rodzi nas dla Chrystusa w Jego Kościele. Dlatego medytujmy nad Maryją i z Maryją, aby zbawienie stało się naszym udziałem!

\subsubsection{Czas i środowisko Jej życia}

Spróbujmy zestawić kilka danych z różnych źródeł historycznych, które przybliżą czas i środowisko życia Maryi. Historycy starożytni nie zajmowali się postacią i życiem Jezusa z Nazaretu, a tym bardziej Maryją. Nie mamy do dyspozycji żadnych dokumentów ówczesnej rzymskiej administracji państwowej czy żydowskiej religijnej. Datę narodzin i śmierci (wniebowzięcia) Maryi możemy ustalić jedynie w przybliżeniu, przez odniesienie do danych historycznych dotyczących Jezusa z Nazaretu, Jej Syna ${ }^{1}$.

Objawienie chrześcijańskie ma charakter historyczny, to znaczy dokonało się poprzez fakty i wydarzenia historyczne, tworzące razem jedną ekonomię zbawienia. Centralnym wydarzeniem owej ekonomii jest Jezus Chrystus, prawdziwy historycznie Człowiek, a zarazem prawdziwy Bóg. Kiedy urodził się Jezus? „Kiedy tam [w Betlejem] przebywali, nadszedł dla Maryi czas rozwiązania. Powiła swego pierworodnego Syna, owinęła Go w pieluszki i położyła w żłobie, gdyż nie było dla nich miejsca w gospodzie” (Łk 2, 6n). Jako ramy czasowe życia Jezusa podaje się najczęściej okres panowania rzymskich cesarzy z dynastii julijsko-klaudyjskiej: Augusta I (lata 31 przed Chrystusem - 14 po Chrystusie) i Tyberiusza (lata 14-37 naszej ery). Datę narodzin Jezusa ustalono pierwotnie błędnie, gdyż mnich Dionizy Mniejszy (ok. 470 - ok. 550) pomylił się o kilka lat.

Według współczesnych obliczeń życie Jezusa przypada pomiędzy 7-6 rokiem przed naszą erą a 30 rokiem naszej ery, która właśnie od Niego bierze swoją nazwę i początek. W Nowym Testamencie nie ma żadnych konkretnych wskazówek co do daty narodzenia Jezusa. Pierwszym, który jednoznacznie stwierdził, że narodził się On 25 grudnia, był Hipolit

Por. J. Jezierski, Maryja początkiem nowego świata. Zarys mariologii katolickiej, Olsztyn 2011, s. 7 . 
Rzymski (ok. 170-235). Wyczytujemy to z jego komentarza do Księgi Daniela z roku 204. Uważna lektura Ewangelii św. Łukasza pozwala powiązać narodziny Jana Chrzciciela z narodzinami Jezusa i w konsekwencji także wyprowadzić dzień 25 grudnia jako datę narodzin Jezusa w Betlejem. W tym dniu obchodzono w Izraelu święto konsekracji świątyni, ustanowione przez Judę Machabeusza w 164 roku przed narodzeniem Chrystusa. Uzasadniona jest zatem teza, zgodnie z którą data narodzin Jezusa oznacza, że wraz z Nim urzeczywistniła się konsekracja świątyni, czyli że Bóg realnie i osobowo wszedł w ziemski i ludzki wymiar egzystencji. Jednakże swoje liturgiczne kształty uroczystość Narodzenia Pańskiego przybrała ostatecznie dopiero w IV wieku, kiedy to chrześcijanie w miejsce pogańskiego święta niezwyciężonego słońca (sol invictus) zaczęli świętować narodziny Chrystusa jako zwycięstwo prawdziwej światłości.

Potwierdzeniem wcześniejszej daty narodzin Jezusa niż, jak dotąd przyjmowano, przełom lat 1 przed naszą erą / 1 naszej ery jest pojawienie się Gwiazdy Betlejemskiej oraz przybycie trzech magów (por. Mt 2, 1-2). Co to była za gwiazda? Astronomowie (Johannes Kepler, Konradin Ferrari d’Occhieppo, Friedrich Wiesler) przyjmują, iż pojawiła się ona w latach 7-6 przed naszą erą i była wynikiem koniunkcji Jowisza i Saturna w gwiazdozbiorze Ryb. To ustawienie ciał niebieskich wyzwoliło znaczną ilość energii i wytworzyło potężną wiązkę dodatkowego światła. A zatem ta wielka koniunkcja planet mająca miejsce w latach 7-6 przed Chrystusem została obliczona przez biblijnych magów ${ }^{2}$.

Dlatego uzasadnione jest przyjęcie, iż Jezus narodził się w Betlejem 25 grudnia 7 roku przed naszą erą, a w piątek 7 kwietnia 30 roku naszej ery (14 nissan), o godzinie dziewiątej, licząc od wschodu słońca, czyli o godzinie piętnastej według współczesnej rachuby czasu, został zamordowany, ponosząc tragiczną śmierć na drzewie krzyżaª

W oparciu o te historyczne wyznaczniki można określić datę narodzin i śmierci Maryi. W tamtym czasie praktyką powszechnie przyjętą w Izraelu i w krajach sąsiednich było wczesne wydawanie dziewcząt za mąż. Do zamążpójścia przeznaczano dziewczynę w wieku 12-16 lat. Stąd też można wnioskować, że Maryja w rodzinie Joachima i Anny przyszła na świat

\footnotetext{
2 Por. J. Ratzinger - Benedykt xvi, Jezus z Nazaretu. Dzieciństwo, przeł. W. Szymona, Kraków 2012, s. 121-127.

3 Por. A. A. Napiórkowski, Jezus Chrystus Objawiony i Objawiający. Chrystologia fundamentalna, wyd. 2, Kraków 2016, s. 45-47 (Myśl Teologiczna, 61).
} 
między 23 i 19 rokiem przed naszą erą. Według apokryfów Jej rodzice byli bogaci i pobożni, ale bezdzietni. Wspólnota żydowska interpretowała to jako znak dezaprobaty ze strony Jahwe. $Z$ tego powodu Joachim i Anna cierpieli, jednak przez modlitwę i post nie ustawali w błaganiach do Najwyższego o potomstwo. Ostatecznie Anna urodziła córkę, której Joachim nadał imię Miriam. Było to ich jedyne dziecko.

W chwili śmierci Jezusa Maryja mogła liczyć od 49 do 53 lat. Zgodnie $\mathrm{z}$ tradycją (Jezusowym testamentem z krzyża) po tym wydarzeniu towarzyszyła Janowi Ewangeliście i zamieszkała u niego w Efezie (na terenie dzisiejszej Turcji). Wolno przyjąć, że żyła jeszcze kilkanaście lub nawet kilkadziesiąt lat. Jeśliby umarła w 50 roku, miałaby wówczas około 69-73 lat ${ }^{4}$.

\subsection{2. „Jest piękna” - imię Miriam}

Żadne świadectwo nie mówi jednoznacznie, że Maryja wywodziła się z domu Dawida. Włączenie Jezusa do pokolenia Dawidowego dokonało się dzięki Józefowi, i to przez adopcję (por. Mt 1, 16. 19-25; Łk 1, 27; 2, 4. 48; 3, 23; Ewangelia Markowa milczy o Józefie). Z kolei o pewnym pokrewieństwie Maryi z matką Jana Chrzciciela nie informuje nas żaden Ewangelista poza św. Łukaszem.

Joachim i Anna nadali swojej córce hebrajskie imię Miriam (aramejskie: Mariam), co oznacza „piękna”, „przynosząca radość”, „pani”. Biblia uczy, że Maryja byłą piękna, gdyż była „pełna łaski”. Grecki termin charis oznacza piękno, wdzięk. Odpowiednikiem greckiego charis jest łaciński termin gratia, który również można tłumaczyć jako piękno. Refleksję nad tak rozumianym "pięknem” w sensie nie tyle wizualnym, ile psychicznym i duchowym, można poszerzyć o takie określenia jak „dbanie o rozwój”, „trwanie w uwielbieniu”, „otwarcie na innych”, „słuchanie słowa”, „zjednoczenie z Bogiem w cierpieniu”, „Piękna - Oblubienica”, „Piękna - Królowa”.

Warto zauważyć, iż w większości objawień prywatnych sama Maryja ukazywała się jako niewymownie piękna w swojej kobiecości. Tak było w Lourdes, w Gietrzwałdzie czy w Fatimie. Wizjonerka z Gietrzwałdu, Justyna Szafryńska, opisywała Maryję jako „śliczną Panią”, która z uśmiechem zachęcała do odmawiania różańca. Ta Pani, otoczona niezwykłą jasnością, ubrana na biało, z długimi włosami opadającymi na ramiona,

\footnotetext{
4 Por. J. Jezierski, Maryja początkiem nowego świata..., dz. cyt., s. 7.

5 Por. M. Rosik, Biblijna ikona piękna Maryi, „Salvatoris Mater. Kwartalnik Mariologiczny” [dalej: SM] 15 (2013) nr 1-4, s. 11-22.
} 
siedziała na złocistym tronie, udekorowanym perłami ${ }^{6}$. Podobnie opisywano Najświętszą Pannę w trakcie objawień na ziemi belgijskiej, w wiejskich parafiach Beauraing i Banneux. Maryja objawiała się tam od 29 listopada 1932 roku aż do 3 stycznia 1933 roku i była nazywana właśnie „Piękną Panią”.

Zgodnie ze zwyczajem w modlitwie i liturgii posługujemy się staropolską formą imienia Matki Jezusa - Maryja. Tę formę znajdujemy w polskim przekładzie Pisma Świętego z języków oryginalnych. Tym samym podkreślamy wyjątkowość Matki Jezusa, odróżniając ją od wielu kobiet o imieniu Maria.

Natchniony autor Księgi Mądrości wyznaje:

Ją to pokochałem, jej od młodości szukałem:

pragnąłem ją sobie wziąć za oblubienicę

i stałem się miłośnikiem jej piękna.

Sławi ona swe szlachetne pochodzenie, gdyż obcuje z Bogiem

i miłuje ją Władca wszechrzeczy,

bo jest wtajemniczona w wiedzę Boga

i w Jego dziełach dokonuje wyboru $($ Mdr 8, 2).

Nie będzie nadużyciem interpretacyjnym, jeśli te słowa ze Starego Testamentu odniesiemy do Maryi i utożsamimy Ją z mądrością. Tym samym wpiszemy się w poczet miłośników Jej piękna. Przez niniejszą książkę pragnę głosić Jej piękno. Według tradycji z Nazaretu pochodziły szczególne ładne dziewczęta. Chodzi mi jednak o coś więcej. Piękno Maryi było bowiem nie tylko Jej zewnętrzną cechą, dotyczyło nie tylko wyglądu - ono wręcz Ją konstytuowało. Choć nie znamy rysów Jej twarzy, to Ją rozpoznajemy. Jej piękno oznacza świętość, gdyż Bóg Ojciec, wybierając Ją na Matkę swego odwiecznego Syna, obdarzył Ją samym pięknem duchowym ${ }^{7}$ Maryja była piękna nie tylko dlatego, że otrzymała takie imię. Była urzekająco piękna nade wszystko duchowo. Jej wewnętrzna subtelność i doskonałość promieniowały z nieprawdopodobnej jedności z Bogiem - jak nigdy i u nikogo z ludzi, dlatego też to Ona zrodziła Jezusa Chrystusa, odwiecznego Bożego Syna, który z Niej przyjął ludzkie ciało.

Via pulchritudinis nie jest jedynym sposobem mówienia o Matce Bożej. Jednak ukazywanie Maryi na drodze piękna i prawdy - jak zauważa Bruno

${ }^{6}$ Por. C. Ryszka, Łaska objawień. Barbara Samulowska z Gietrzwałdu, Gietrzwałd 2004, s. 36 .

7 Por. J. Królikowski, Piękno manifestacją świętości Maryi, sM 15 (2013) nr 1-4, s. 62-77. 
Forte - daje gwarancję większego przyciągania uwagi słuchacza, ponieważ będzie w tym przekazie więcej narracji i symboliki ${ }^{8}$.

\subsection{Kontekst współczesny}

Teologia jako nauka powinna wyraźnie odnosić się do życia współczesnego jej człowieka, dla którego przecież jest uprawiana - ma służyć mu na jego drodze zarówno do przemiany doczesności, jak i osiągnięcia życia wiecznego. Ciągłe nadmierne izolowanie się Kościoła od świata jest wielkim nieporozumieniem i zaprzeczeniem misji, jaką Jezus zlecił swoim naśladowcom. Dlatego teologia, aby kompetentnie przekazywała orędzie o Bogu, musi być zorientowana antropologicznie. Najpierw i ostatecznie jest ona nauką dla człowieka i o człowieku, jego istocie, powołaniu i spełnieniu. Determinowana jest przez wyznaczniki życia społecznego, kulturowego, gospodarczego i politycznego, choć w wielu wymiarach znacznie je przekracza. Niemniej mając na względzie granice własnej komunikatywności (problem języka, treści i przekazu), teologia pragnie wypowiadać się zrozumiale dla swojego odbiorcy.

Dlatego w uprawianiu refleksji teologicznej, i to szczególnie w obszarze mariologii, nie można pominąć nowych prądów i zjawisk, jak choćby dokonującej się współcześnie rewaloryzacji kobiecości, prężnie rozwijającej się teologii feministycznej, teologii wyzwolenia, postulatów teologii narracyjnej, teologii doświadczenia, teologii nadziei, ekoteologii papieża Franciszka, teologii kultury i piękna lub też maryjnej pobożności ludowej, która tak często przez teologię uniwersytecką jest zbywana milczeniem. Ubogaceniem mariologii okazują się z pewnością osiągnięcia dialogu ekumenicznego i międzyreligijnego. W zakresie polskiej teologii kontekstualnej należałoby natomiast oczekiwać także większego uwzględnienia jasnogórskiej mariologii i maryjności czy sugestii personalizmu i polskiej teologii wolności, zaproponowanej przez ks. Franciszka Blachnickiego, jak również polskiej teologii narodu (Hieronim Kajsiewicz, August Hlond, Stefan Wyszyński, Jan Paweł II, Czesław Stanisław Bartnik)9.

8 Por. B. Forte, Maryja, ikona tajemnicy. Zarys mariologii symboliczno-narracyjnej, przeł. B. Widła, Warszawa 1999, s. 21 (Theotokos, 8).

9 Por. A. A. Napiórkowski, Teologie Xx $i$ XXI wieku, Kraków 2016. 


\subsubsection{Nowa mariologia}

Ubiegłe stulecie było dość interesującym okresem przeobrażeń w mariologii. Mariologia maksymalistyczna w pierwszej połowie xx wieku - zwieńczona ogłoszeniem przez Piusa XII w 1950 roku dogmatu o wniebowzięciu Maryi - charakteryzowała się nadmiarem i przesadą. Niektórzy teolodzy nie wahali się włączać do maryjnych przywilejów nawet wszechpośrednictwa czy współodkupienia. Doprowadziło to ostatecznie do swoistego kryzysu i krytyki takich niewłaściwych postaw w okresie przygotowań do Soboru Watykańskiego II (1962-1965). Aby uniknąć skrajności, postulowano złączenie mariologii z chrystologią i eklezjologią. Uwzględnienie badań biblijnych, patrystycznych, liturgicznych i historycznych zaowocowało trwałym wpisaniem mariologii w nurt chrystologiczno-eklezjologiczny i ogłoszeniem powstania nowej mariologii przez Vaticanum II w VIII rozdziale Konstytucji dogmatycznej o Kościele Lumen gentium.

Jednakże po Soborze nastąpił wśród teologów czas milczenia w kwestiach maryjnych. Niemal w ogóle nie pojawiały się publikacje na ten temat, a jeśli już, to z rzadka, w kluczu soteriologicznym lub eklezjotypicznym. Jednym $\mathrm{z}$ tych, którzy w latach osiemdziesiątych $\mathrm{xx}$ wieku przełamali posoborowe milczenie na temat Maryi, był Edward Schillebeeckx. Flamandzki teolog stwierdził: „Autentyczny kult maryjny należy do istoty chrześcijaństwa, w którym tylko Jezus Chrystus, odsyłający wszystkich ludzi do jedynego Boga [...], może być nazwany punktem centralnym i ogniskowym" ${ }^{\prime \prime}$. Z kolei na gruncie niemieckim pierwsze mariologiczne publikacje wyszły spod pióra Heinricha Petriego i Wolfganga Beinerta.

W polskim Kościele sytuacja mariologii i maryjności przedstawiała się o wiele lepiej niż w krajach Europy Zachodniej - udało się tutaj uniknąć wspomnianego wyżej kryzysu. Biskupi, jak kardynał Stefan Wyszyński czy kardynał Karol Wojtyła, cenili i chronili wartości, które niosła ze sobą tradycyjna pobożność maryjna. Odnowa mariologii postępowała stopniowo. Ten ewolucyjny, a nie rewolucyjny, system zmian przyniósł właściwe skutki. Rozwinęła się w Polsce nowa mariologia, która jednak ani nie skompromitowała, ani nie zniszczyła mariologii poprzedniej ${ }^{11}$.

W perspektywie globalnej, ale także europejskiej i polskiej, teologia nadal dziś się przeobraża. Wynika to nie tylko z tego, że chrześcijaństwo

${ }^{10}$ Cytuję za: B. Ferdek, Duch Boży nad wodami Renu. Refleksje nad ścieżkami nadreńskiej pneumatologii, Wrocław 2010, s. 230.

${ }^{11}$ Por. J. Jezierski, Maryja początkiem nowego świata..., dz. cyt., s. 88. 
stopniowo przestaje być religią europejską, staje się bardziej globalne, lecz także jest skutkiem potężnych procesów sekularyzmu i sekularyzacji zachodzących w cywilizacji euroatlantyckiej. Odzwierciedleniem zmian w teologii jest chociażby wielość różnych nowych kierunków ${ }^{12}$. W cały ten ciąg przeobrażeń wpisuje się potrzeba nowej teologii, a jeszcze bardziej uwspółcześnionej mariologii. Posoborowa teologia - opuszczająca gmach eklezjologii instytucjonalnej i nadmiernego dogmatyzmu, a kierująca się w stronę większego uwzględnienia źródeł biblijnych, wskazań antropologicznych i personalistycznych - budzi nadzieję na nowe podejście i ożywienie nauki o Maryi, Matce Jezusa. Teologowie rozważają aktualnie kwestię nowej mariologii. Zadają pytanie o relacje Maryi do Kościoła i do świata dziś. Jak mają one wyglądać? ${ }^{13}$

Naturalnie nie chodzi tutaj o negację czy krytykę zastanej mariologii, ale o wprowadzenie w nią - w sposób odpowiedzialny - nowych teologicznych dokonań, osiągnięć i tendencji. W mariologii krzyżują się zagadnienia chrystologiczne, antropologiczne, soteriologiczne, eklezjologiczne, liturgiczne i eschatologiczne. Nowa mariologia winna określić teologiczne związki Maryi z Jezusem Chrystusem, wyznaczyć właściwe Jej miejsce i rolę w życiu Kościoła oraz formy Jej kultu. Analiza treści objawionych pod kątem mariologii i maryjności musi nie tylko być metodologicznie uporządkowana, lecz także prezentować je $\mathrm{w}$ ścisłym związku z pozostałymi prawdami wiary chrześcijańskiej. Obecnie w mariologii funkcjonuje dość sztywny schemat chrystotypiczny lub eklezjotypiczny. Nie wydaje się on jednak rozwiązaniem najwłaściwszym. Odnowiona mariologia powinna mieć raczej charakter integralny. Podobne tendencje istnieją zresztą w obszarze eklezjologii, gdzie zakorzenił się już wzorzec nauki o Kościele w świetle teologii fundamentalnej lub w ujęciu teologii dogmatycznej. Także i tutaj należy postulować i wypracowywać eklezjologię holistyczną ${ }^{14}$.

Trzeba także pamiętać, że doktryna maryjna swoje ubogacenie znajduje w bezpośrednim kontakcie z pobożnością czy duchowością. Nauka o Maryi musi być otwarta na inspiracje wypływające $z$ modlitwy, kontemplacji,

${ }^{12}$ Zob. A. A. Napiórkowski, Teologie Xx i XXI wieku, dz. cyt., s. 448. Prezentuję w tej monografii 30 najważniejszych kierunków teologicznych, które zmieniły oblicze Kościoła w ostatnich dziesięcioleciach; oczywiście nie są to wszystkie prądy teologiczne ostatniego stulecia.

${ }^{13}$ Por. W. Siwak, Jaka Maryja dla XxI wieku? Maryja w korelacjach $z$ Bogiem, Kościołem i człowiekiem, SM 11 (2009) nr 4, s. 195-248.

${ }^{14}$ Dałem temu zresztą szerszy wyraz w swojej książce Bosko-ludzka wspólnota. Podstawy katolickiej eklezjologii integralnej, Kraków 2010, s. 435 (Myśl Teologiczna, 65). 
ascezy, praktyk postu, jałmużny, służby bliźniemu czy mistycznych doświadczeń. Tak pobudzona i ożywiana nauka o Matce Jezusa będzie też z pewnością pomocna w zasypywaniu głębokiej przepaści między dogmatyką a maryjną pobożnością. To wezwanie do duchowości opartej na solidnej teologii staje się tym bardziej konkretne, że w Kościele pojawiło się wiele nieformalnych grup, które mocno czczą Maryję i definiują Ją jako normatywną regułę życia i pomoc w naśladowaniu Chrystusa.

\subsubsection{Początki teologii feministycznej}

Powstanie i rozwój teologii feministycznej w połowie lat sześćdziesiątych $\mathrm{xx}$ wieku łączy się z ruchem na rzecz odnowy Kościoła i teologii, tak na gruncie amerykańskim, jak i europejskim. Wpisuje się on w teologię wyzwolenia, w kreowanie nowej świadomości wiernych świeckich w Kościele czy też rewolucję moralną 1968 roku. Teologia feministyczna ma być uprawiana ze szczególnym uwzględnieniem perspektywy kobiecej i nieść ze sobą wątki duchowości, społeczne, socjalne, a przy tym mocno osobowe, a także brać pod uwagę dialog ekumeniczny i międzyreligijny. Jeśli feminizm rozumieć jako uzasadnioną kobiecą emancypację, ta forma teologii jest teologią kontekstualną, stronniczą, gdyż wynika z krytyki dominacji męskiego obrazu Boga w świadomości społeczno-religijnej.

Jako znaczącą datę w kształtowaniu się teologii feministycznej rozumianej jako teologia wyzwolenia kobiet niektórzy wskazują rok 1958, kiedy pierwsza kobieta została ordynowana na urząd pastora w Kościele Ewangelickim w Niemczech. Temat obecności i zadań kobiet w Kościele z pewnością wzmocniło także powołanie do życia w 1948 roku w Amsterdamie Światowej Rady Kościołów. W 1994 roku na wydziale teologii ewangelickiej Uniwersytetu w Marburgu kobieta po raz pierwszy otrzymała katedrę profesorską.

W teologii katolickiej pojawienie się prądu feministycznego na pewno należy natomiast powiązać z ekumenicznym otwarciem Kościoła. Nie dziwi zatem, że pierwsze inspiracje znalazły się w encyklice Pacem in terris św. Jana XXIII (1963), który otwierając Sobór Watykański II, zastrzegł, że soborowa odnowa nie może pominąć działania na rzecz jedności chrześcijan. Dlatego o kobietach czytamy w Konstytucji duszpasterskiej o Kościele w świecie współczesnym tegoż Soboru: „Z pewnością nie wszyscy ludzie stoją na równym poziomie pod względem sprawności fizycznej oraz zdolności intelektualnych i moralnych. Wszelka jednak dyskryminacja w zakresie fundamentalnych praw osobowych, czy to społeczna, czy kulturalna, 
z powodu płci, rasy, koloru skóry, pozycji społecznej, języka czy religii, powinna być przezwyciężona i zlikwidowana jako sprzeczna $\mathrm{z}$ zamysłem Bożym. Godny ubolewania jest fakt, że te fundamentalne prawa osoby dotąd nie wszędzie w pełni są zagwarantowane. Dzieje się tak, jeżeli odmawia się kobiecie możliwości wolnego wyboru małżonka i obierania stanu życia lub dostępu do takiego samego wykształcenia i rozwoju kulturalnego, jaki zapewnia się mężczyźnie" ${ }^{15}$. Ojcowie soborowi dopuścili kobiety do studiowania teologii, a także do jej nauczania.

Odtąd zaczęly się pojawiać watykańskie dokumenty poświęcone kobietom, m.in. deklaracja Inter insigniores Kongregacji Nauki Wiary (1976) czy list apostolski św. Jana Pawła II Mulieris dignitatem o godności i powołaniu kobiety (1988). Ojciec Święty z Polski był też pierwszym papieżem, który użył terminu "nowy feminizm” w pozytywnym znaczeniu. W swojej encyklice Evangelium vitae (1995) wezwał kobiety do współtworzenia nowej kultury opartej na szacunku dla życia. Zaznaczył konieczność obecności kobiet w każdej dziedzinie życia społecznego, gdyż ich talenty są zbyt cenne, aby trzymać je w ukryciu.

Mają stawać się promotorkami „nowego feminizmu”, który nie ulega pokusie naśladowania modeli „maskulinizmu”, ale umie rozpoznać i wyrazić autentyczny geniusz kobiecy we wszystkich przejawach życia społecznego, działając na rzecz przezwyciężania wszelkich form dyskryminacji, przemocy i wyzysku [...]. I ja zwracam się do kobiet $z$ naglącym wezwaniem: Poje dnajcie ludzi z życiem. Jesteście powołane, aby dawać świadectwo prawdziwej miłości - tego daru z siebie i tego przyjęcia drugiego człowieka, które dokonują się w sposób szczególny we wspólnocie małżeńskiej, ale które muszą stanowić istotę każdej innej więzi między osobami ${ }^{16}$.

Według niektórych początki akademickiej teologii feministycznej wyznaczają dwie publikacje katolickich teolożek: Amerykanki Mary Daly Beyond God the Father: Toward a philosophy of women's liberation (1973) oraz Holenderki Cathariny J. M. Halkes Gott hat nicht nur stärke Söhne. Grundzüge einer feministischen Theologie (1980). Tak zapoczątkowaną działalność podjęły teologiczne zrzeszenia kobiet, jak Ekumeniczne Forum Kobiet

${ }^{15}$ Sobór Watykański II, Konstytucja duszpasterska o Kościele w świecie współczesnym Gaudium et spes, 29.

${ }^{16}$ Jan Paweł II, Encyklika Evangelium vitae o wartości i nienaruszalności życia ludzkiego, 99. 
Chrześcijańskich działające od 1980 roku czy Europejskie Towarzystwo Kobiet do Badań Teologicznych (European Society of Women in Theological Research, ESWTR) istniejące od 1985 roku. Oficjalna refleksja teologiczna była dotąd niemal wyłącznie dziełem mężczyzn.

Ujęcie feministyczne z pewnością może wzbogacić dotychczasową hermeneutykę teologiczną. Przedstawicielki teologii feministycznej widzą w niej szansę na odnowienie Kościoła i pogłębienie hermeneutyki Bożego objawienia. Według nich istotne przesłanie feminizmu jako krytyki nieobiektywnych męskiej kultury i społeczeństwa ma korzenie chrześcijańskie - dlatego Kościół potrzebuje dziś oczyszczenia z grzechu seksizmu ${ }^{17}$, który niszczy nie tylko kobietę, lecz także mężczyznę. Teologię feministyczną należy postrzegać jako sprzeciw wobec androgenicznego chrakteru społeczeństwa. Należy wypracować nowe zasady interpretacji objawienia, aby oczyścić je z nadmiernych męskich wpływów, co będzie skutkować nowym rozumieniem Boga, inną interpretacją wcielenia Jezusa, nową chrześcijańską antropologią, poszerzoną nauką o Kościele, aż po zmiany we wszystkich dyscyplinach teologicznych.

\subsubsection{Między feminizmem a emancypacją}

Przewartościowania, które dokonują się w wielu wymiarach życia społecznego, mają z pewnością ambiwalentny charakter. Są zbyt szerokie, aby można było ocenić je jednoznacznie pozytywnie lub negatywnie. Pomijając negatywne skutki, które dosięgają nas jako społeczeństwa (post)modernistycznego i owładniętego mirażem globalizacji, spróbujmy wymienić kilka pozytywnych.

Z pewnością do pozytywnych następstw cywilizacyjnego postępu należą osiągnięcia techniczne, żywieniowe, higieniczne, medyczne oraz oświatowe. Do tego kręgu zaliczyć też trzeba dowartościowywanie kobiety. Jej emancypacja polega m.in. na większym uczestnictwie i kreatywności w życiu społecznym. Obszary obecności i czynnego udziału kobiet w rozmaitych przejawach życia kulturowego, społecznego, technicznego i politycznego znacząco się poszerzyły. Zainicjowany został proces pogłębiania świadomości istniejącego ucisku płci pięknej i konieczności jej wyzwolenia. Kobieta potrzebuje dziś przede wszystkim duchowości ${ }^{18}$. Dlatego należy dziś odczytać na nowo historię kobiety. Kwestia kobieca musi zostać na nowo

\footnotetext{
${ }^{17}$ Por. E. Adamiak, O co chodzi w teologii feministycznej?, „Więź” 1993 nr 1, s. 68-77.

${ }_{18}$ Por. D. Mastalska, Jaka duchowość maryjna dla kobiet?, SM 12 (2010) nr 1-2, s. 122-168.
} 
rozważona zarówno na polu myśli świeckiej, jak i chrześcijańskiej. W obrębie oficjalnej historii i poza nią - pisaną zawsze przez zwycięzców (czytaj: mężczyzn) ze szkodą dla pokonanych (kobiet) - na nowo odkrywa się niedostrzeganą i stłumioną obecność tego, co kobiece. Systemy społeczno-kulturalne i ekonomiczne automatycznie skazywały kobietę na zależność od mężczyzny i wyzysk z jego strony; podporządkowywały ją planom i potrzebom silniejszej fizycznie płci. Zarówno dla wielkich geniuszy, np. Arystotelesa, jak i dla przeciętnych kobieta była „nieudanym mężczyzną” (mas occasionatus). Powołując się właśnie na Arystotelesa, Tomasz z Akwinu (ok. 1225-1274) w swojej Sumie teologicznej również napisze, że jest ona „mężczyzną niewydarzonym”. W zagadnieniu 92 swojego dzieła, kontynuując tę myśl, stwierdzi, że „kobieta z natury ustępuje mężczyźnie pod względem siły i dostojeństwa". Akwinata głosił, że kobieta potrzebuje mężczyzny nie tylko po to, by rodzić, jak to czynią zwierzęta, lecz także po to, aby być kierowana, gdyż mężczyzna jest doskonalszy przez swój rozum i silniejszy przez męstwo ${ }^{19}$.

Tego typu argumenty miały uzasadniać i wspierać średniowieczny porządek społeczny, który był układem patriarchalnym. Jednak stały przecież w oczywistej sprzeczności z postępowaniem Jezusa wobec kobiet ${ }^{20}$.

Świadomość emancypacyjna, odrzucając historyczne antynomie przeciwstawiające kobietę mężczyźnie, woli dziś mówić o wzajemności, o relacji. Oznacza ona eliminację wszelkiego przeciwstawnego naturze podporządkowania między mężczyzną a kobietą. Niebezpieczeństwem może tu być przesadny feminizm, prowadzący do podporządkowania mężczyzny kobiecie. W ostateczności także dla samych kobiet staje się on zagrożeniem i prowadzi do destrukcji. Kobieta odkrywa swoją prawdziwą kobiecość w odniesieniu do mężczyzny, a mężczyzna realizuje w pełni swoją męskość dopiero w relacji do kobiety. Bóg bowiem stworzył człowieka jako mężczyznę i kobietę. To właśnie dlatego wyzwolenie kobiet jest jednocześnie procesem niosącym wyzwolenie człowiekowi w ogóle.

Kiedy odnowiona świadomość kobiecości zaczyna poszukiwać swoich historycznych uwarunkowań i własnych podstaw teologicznych, jakie stworzył męski obraz Boga na niekorzyść kobiety, wówczas pojawia się teologia feministyczna w swoich wielu różnych przejawach. Wyróżnić w niej można

19 Tomasz z Akwinu, Suma teologiczna, tłum. P. Bełch, t. 7, Londyn 1980, z. 92. a. 1, odp. 1 (s. 103-104). Łaciński odpowiednik: Thomas de Aquino, Summa theologica, I, q. 92, a. 1, ad 1.

${ }^{20}$ Por. B. Forte, Maryja, ikona tajemnicy, dz. cyt., s. 23-24. 
wiele opcji: od pozytywnego feminizmu do agresywnej i rewolucyjnej emancypacji, która szerzy ateizm, antykoncepcję, ekologizm, niszczy tradycyjne normy społeczne, prowadzi walkę z małżeństwem, dąży do feminizacji mężczyzn, propaguje nienawiść do macierzyństwa, upolitycznia język.

Dostrzegając pozytywne elementy feminizmu i odnosząc się krytycznie do patologicznych form emancypacji, współczesna mariologia może znaleźć inspirację w tym pierwszym i przeżyć swoisty renesans. I odwrotnie, po okresie względnej ciszy tematyka mariologiczna pojawia się coraz częściej w teologicznych dyskusjach orientacji feministycznej. Jednak nie wszystkie bodźce pochodzące z teologii feministycznej, która przeradza się często w radykalną teologię wyzwolenia, zasługują na większą uwagę. Już na wstępie należy większość z nich ocenić dość krytycznie, natomiast odpowiedzialne propozycje przeanalizować i ubogacić nimi świat maryjnej wiedzy i pobożności.

Radykalna teologia feministyczna nadmiernie podążyła w kierunku postulatów wyzwolenia, które niestety mają zbyt mało wspólnego $\mathrm{z}$ autentyczną teologią feministyczną, albowiem przesadnie koncentrują się na doświadczonych przez kobiety w historii cierpieniach, ich ucisku psychicznym i seksualnym, ich socjalnej degradacji. Krytyka feministyczna kwestionuje nawet autorytet biblijnych podstaw, domagając się nowej postaci objawienia, a zwłaszcza jego nowej interpretacji. Pod adresem klasycznej teologii wysuwa zarzut, że zignorowała ona całkowicie doświadczenie połowy rodzaju ludzkiego, że przemawiała językiem płci, przedstawiając najczęściej Boga w postaci męskiej jako dzierżącego hegemoniczną władzę. W tak ukierunkowanej teologii feministycznej trudno się wystrzec podobnych błędów ${ }^{21}$.

Natomiast bardziej rzetelne i racjonalne przyczynki do teologii feministycznej zasługują na należny im szacunek, choćby z racji tego, że przyczyniają się do osiągnięcia pełniejszego obrazu Boga. Skorygowanie obrazu Stwórcy jako wyłącznie Ojca może pomóc mężczyźnie zaakceptować kobiece elementy własnej istoty, kobiecie zaś - znaleźć swój pełniejszy wyraz w wolności, gdyż oboje są w autentyczny sposób ludźmi stworzonymi na obraz Boga. Urzeczywistnia się On w jedności i w zróżnicowaniu. Jest głębią tajemniczą i nieprzystępną (cecha kobieca) i jednocześnie darem i wyjściem $\mathrm{z}$ siebie (cecha męska). W tym sensie Boga trinum et unum, tajemniczego i znanego, bliskiego i odległego, fascinosum et tremendum, można wzywać jako Ojca i Matkę, naszego Ojca i naszą Matkę.

\footnotetext{
${ }^{21}$ Por. tamże, s. 27-28.
} 


\subsubsection{Dowartościować kobiecość Maryi}

Podwójna tendencja, krytyczna i propozycjonalna, widoczna jest także w nastawieniu teologii feministycznej wobec Matki Jezusa. Przede wszystkim należy tu uwzględnić niepodlegający zakwestionowaniu element historyczno-kulturowy. Niezależnie od tego, czy postrzegamy w Świętej Dziewicy najsubtelniejszy i najpiękniejszy obraz dążenia człowieka do dobra i piękna, czy mało ważny twór przesądu i niewiedzy, Jej postać jest w Europie głównym elementem kształtującym koncepcję kobiety. Jest Ona jedną z niewielu postaci kobiecych, które zyskały status mityczny - i to szczególny, który od ponad dwóch tysięcy lat głęboko przenika całą naszą kulturę ${ }^{22}$.

Ambiwalentny charakter postulatów feministycznych widać w podejściu np. do sprawy dziewictwa. Ten rodzaj teologii wtedy tylko dziewictwo kobiet ujmuje jako rzeczywistość pozytywną, gdy jest ono rozumiane jako autonomia, jako pewien stopień niezależności społecznej kobiety, jako forma jej emancypacji. W tym świetle teologia feministyczna pozytywnie kwalifikuje dziewictwo Maryi. Takie podejście naznaczone jest równocześnie poważnym brakiem, a mianowicie nie ma tu odniesienia chrystologicznego. Zarówno dziewictwo Maryi, jak i Jej macierzyństwo należy interpretować chrystologicznie i eklezjologicznie. Poprawne chrześcijańskie pojmowanie dziewictwa ujmuje je nie jako wartość samą w sobie, ale jako sposób życia zupełnie poświęconego Trójjedynemu Bogu. Chrześcijańskie dziewictwo oznacza ofiarowanie się w całości Bogu. Takie nastawienie winno w konsekwencji prowadzić do ofiarności i bezinteresowności na rzecz bliźnich ${ }^{23}$.

W tym kontekście spojrzenie na Maryję może być bogatsze i pełniejsze - może dokonać się rewaloryzacja jej kobiecości, sprowadzanej nieraz wyłącznie do wymiaru „cichej i pokornej służebnicy”. Wymiar kobiecości Matki naszego Pana - ciągle bowiem niepotrzebnie pomijany i okrywany wstydliwym milczeniem - był przecież podstawą Jej wspaniałego i głębokiego życia duchowego. Ponadto postać kobiety osiągającej spełnienie w macierzyństwie Bożym przesłoniła inne możliwości kobiecej kreatywności.

W okresie poprzedzającym Sobór Watykański II wskutek pruderii i wrogości wobec seksualizmu doszło do swoistej tabuizacji w zakresie przenoszenia seksualnych obrazów na wewnętrzne boskie relacje w Trójcy Świętej. Bóg uchodził za absolutnie świętego i czystego. Dziś w teologii mówi się coraz śmielej o Jego słabości, niemocy, cierpieniu. Już w latach trzydziestych

${ }^{22}$ Por. M. Warner, Sola fra le donne. Mito e culto di Maria Vergine, Palermo 198o, s. 19.

${ }^{23}$ Por. J. Jezierski, Maryja początkiem nowego świata..., dz. cyt., s. 39-40. 
xx wieku protestancki męczennik Dietrich Bonhoeffer twierdził, że prawdziwy Bóg objawienia chrześcijańskiego nie jest Bogiem potężnym i silnym. Z pojawieniem się feminizmu w latach sześćdziesiątych zaczęto polemicznie i agresywnie akcentować kobiecość Boga przeciwko panującemu patriarchalnemu Jego obrazowi. Teologia feministyczna nie mówiła już „Ojcze nasz”, lecz „Matko nasza”, a zamiast „Jezus Chrystus”, wprowadzono pojęcie "Duchowa” (Geistin). Stało się to przyczyną poważnych zawirowań w obrębie tej problematyki, która zabrnęła w ślepą uliczkę. Jednakże później wiele światła w tę naukę wniosło kilku odważnych katolickich uczonych. Warto zatrzymać się na interesujących propozycjach francuskiego teologa Yves'a Congara, zawartych w trylogii o Duchu Świętym ${ }^{24}$, gdzie pisze on o „macierzyństwie w Bogu” i o „kobiecości Ducha Świętego”. Drogę do dalszej refleksji otworzyli niemieccy teologowie, jak Albrecht von Raab-Straube i Dorothee Sölle (1929-2003). Ponownie ożywiona ezoteryka i mistyka - jak zauważa Sölle - akcentują powiązanie Boga z ziemią i Jego potrzebę, by pomógł Mu człowiek. Jak podkreśla ta ewangelicka teolożka i pacyfistka, Bóg potrzebuje każdego człowieka. Boga i człowieka łączy kosmiczna solidarność. Stąd właśnie wypływa istotna dla kobiety funkcja pomocy (die Rolle der Helferin), zyskuje ona Boskie natchnienie (die göttliche Inspiration). Sölle twierdzi nawet, że należy wierzyć w boskość Maryi.

Rewaloryzacja kobiecości może mieć także pozytywne znaczenie dla dowartościowania zasady Maryjnej w eklezjologii. Zwraca na to uwagę Benedykt Xvi, stwierdzając, że zasada Maryjna symbolizuje wnętrze Kościoła i oznacza miłość, posłuszeństwo, łagodność, cierpliwość, miłosierdzie i spontaniczność. Jest także uzupełnieniem zasady Piotrowej odnoszącej się do zewnętrza Kościoła, a niosącej ze sobą apostolskość, strukturę, urząd, hierarchiczność, instytucjonalność i porządek. Obie zasady - Maryjną (kobiecość) i Piotrową (męskość) - należy naturalnie postrzegać jako konstytutywne i kongruentne, w żadnym natomiast wypadku jako przeciwstawne. Piotr i Maryja pozostają $\mathrm{w}$ przestrzeni eklezjalnej w relacji równowagi i przystawalności - jednak zasada Maryjna jest bardziej pierwotna i podstawowa $^{25}$. W swojej eklezjologii Hans Urs von Balthasar opisywał ponadto jeszcze zasadę Janową. Według szwajcarskiego teologa zarówno charyzmatyczno-posłuszna „maryjność” Kościoła, jak i hierarchiczno-sakramentalna „piotrowość” okazują się bezskuteczne, jeśli nie są wzmocnione „janowością”,

${ }^{24}$ Zob. Y. Congar, Je crois en l'Esprit Saint, 3 vols, Paris 1979-1980.

${ }_{25}$ Por. A. A. Napiórkowski, Bosko-ludzka wspólnota..., dz. cyt., s. 361-362. 
która poprzez miłość i odniesienie do eschatologii prowadzi do rozwoju Kościoła $^{26}$.

Teologia feministyczna dostrzega w Maryi także naszą siostrę i widzi w niej kogoś sympatyzującego z ludźmi w indywidualnej i społecznej walce o wyzwolenie. Dorothee Sölle, wspomniana przedstawicielka teologii feministycznej, uważa, że w liturgii, w formowaniu się dogmatu i w klerykalnie zabarwionym piśmiennictwie o Maryi aż po średniowiecze nie darzono Jej szczególną miłością. Należała do ubogich i niewykształconych, do żebrzących mnichów i ludu. I tak pozostało właściwie do dzisiaj. Maryja $\mathrm{z}$ racji swej sympatii dla ubogich i uciśnionych, jak sama daje temu wyraz w Magnificat, jest zawsze „wywrotowa”, „strącająca władców z tronu”. Dlatego Sölle dostrzega w Maryi niezastąpiony wzorzec dzisiejszych ruchów wyzwoleńczych ${ }^{27}$.

Amerykańska teolożka Rosemary Radford Ruether, kompetentna reprezentantka teologii feministycznej, uważa mariologię za traktat ważny $\mathrm{z}$ jednej strony unaocznia on religijno-patriarchalną represyjność w walce o autonomię kobiety, z drugiej zaś historia kultu maryjnego mówi nam coś o autentycznej kobiecej mocy, której w tej walce nigdy nie udało się całkowicie zdusić ${ }^{28}$. Obraz Królowej Niebios pomagałby przezwyciężyć patriarchalny obraz Boga i „na szerszej płaszczyźnie umieścić zmartwychwstanie religijne dojrzałej kobiety"29.

Na płaszczyźnie teologicznej warto także odwołać się do chrystologii i eklezjologii. Mariologia musi zawsze być uprawiana w ich kontekście, gdyż łączność Matki z Synem w dziele zbawczym uwidacznia się od chwili dziewiczego poczęcia Chrystusa i trwa po dzień dzisiejszy ${ }^{30}$. Boskiej tajemnicy zbawienia, która utrzymuje się i objawia w Kościele, nie da się pojąć bez chwalebnej Dziewicy, a zasada Piotrowa zyskuje swoje właściwe uzupełnienie i zrozumienie dopiero w zasadzie Maryjnej. Kierunek ten został wprawdzie zainicjowany przez Sobór Watykański II, lecz nie do końca uwzględniono go w myśli teologicznej. Ojcowie soborowi stwierdzili: „Sobór święty, wykładając naukę o Kościele, w którym Boski Odkupiciel

${ }^{26}$ Por. I. Moga, Hans Urs von Balthasar, [w:] Zeitgenössische Kirchenverständnisse. Acht ekklesiologische Porträts, Hrsg. C. Keppler, J. C. Pech, Heiligenkreuz 2013, s. 45-46.

27 Por. D. Sölle, Sympathie, Stuttgart 1978, s. 60.

${ }^{28}$ Por. R. Radford-Ruether, Maria - Kirche in weiblicher Gestalt, München 1980, s. 4.

${ }^{29}$ C. Mulack, Maria. Die geheime Göttin im Christentum, Stuttgart 1985, s. 238.

${ }^{30}$ Por. Sobór Watykański II, Konstytucja dogmatyczna o Kościele Lumen gentium [dalej: $\mathrm{KK}], 57$. 
dokonuje zbawienia, pragnie starannie wyjaśnić zarówno rolę Błogosławionej Dziewicy w misterium Słowa Wcielonego i Ciała Mistycznego, jak i obowiązki odkupionych ludzi względem Bogarodzicy, Matki Chrystusa i Matki ludzi, zwłaszcza wierzących w Chrystusa" ${ }^{31}$.

\subsubsection{Pobożność ludowa}

Współczesne mówienie o Maryi może także z pewnością zostać wzbogacone o wątki ludowej pobożności. Ta forma pobożności, szczególnie w obszarze maryjnej czci, zabezpiecza teologię przed nadmierną racjonalnością, a całemu Kościołowi przypomina o niezbędności modlitwy i uwielbieniu Boga. Wydaje się nawet, że mariologia w swoich akademickich rozważaniach nie tylko nazbyt łatwo pozbywa się tych inspiracji, lecz także wręcz do przesady ich unika. Amerykański baptysta Harvey Cox zauważa, że mówienie o Bogu nastręcza w dzisiejszych czasach trudności, ale jeśli chodzi o Maryję, jest to temat żywotny i zasługujący na uwagę. W religii prostego ludu postać Maryi jest obecna i jaśnieje pełnym blaskiem. W pobożności ludowej Jej imię - według Coxa - skupia w sobie prastare doświadczenie przedchrześcijańskich, pierwotnych religii, wyrażające się w tajemnicy prostego życia, w zgodzie z innymi ludźmi, w harmonii z naturą ${ }^{32}$.

Ponieważ w pobożności maryjnej ta pierwotna wiedza religijna jest jeszcze żywotna, mogłaby dopomóc współczesnym zachować wrażliwość na naturę i jej tajemniczość - bo przecież z Maryją, bardziej niż z Jahwe czy Jezusem, związane były „takie, wyciszane co prawda, pozaczasowe, ale decydujące elementy życia religijnego, jak płodność, płciowość, łono, ziemia i księżyc". Religijna dusza ludu ukazuje skupienie tych pierwotnych elementów w obrazie Maryi. Kult Jej oddawany jest bowiem także wyrazem tęsknoty kobiety za wolnością 33 .

Maryjność w swojej ludowej formie często także stwarza nierozerwalną więź, pozwalającą grupom pozbawionym należytej opieki duszpasterskiej dochować wierności Kościołowi. Ujawniają to zarówno teksty Synodu Biskupów Ameryki Łacińskiej z Puebla (1986), jak i Instrukcja o chrześcijańskiej wolności i wyzwoleniu Liberatis conscientia Kongregacji Nauki Wiary (1986), które usiłują znaleźć dla Maryi należne Jej miejsce w procesie

\footnotetext{
${ }^{31}$ KK 54.

$3^{2}$ Por. H. Cox, Verführung des Geistes, Stuttgart-Berlin 1974, s. 176-178.

33 Por. tamże, s. 179-181.
} 
odnowy Kościoła w Ameryce Południowej ${ }^{34}$. W Instrukcji czytamy, że „Maryja, całkowicie oddana Bogu i zupełnie zwrócona ku Niemu, u boku swojego Syna, jest najdoskonalszą Ikoną wolności oraz wyzwolenia ludzkości i wszechświata. To ku Niej Kościół, którego jest Matką i Wzorem, powinien zwracać wzrok, by zrozumieć w pełni sens swojego posłannictwa" ${ }^{35}$. Watykańska Instrukcja pozytywnie ocenia pobożność ludową, gdyż stwierdza, iż ,jest rzeczą charakterystyczną, że zmysł wiary ubogich, idący w parze z jednoznacznym zrozumieniem tajemnicy zbawczego krzyża, prowadzi do miłości i niezachwianej ufności do Matki Syna Bożego czczonej w licznych sanktuariach"36.

Można tutaj z satysfakcją stwierdzić, iż mimo posoborowych wstrząsów i licznych, często nierozważnych i nieprzemyślanych prób deprecjacji mariologii i maryjności w tym okresie różne formy maryjnej pobożności cieszą się nadal uznaniem szerokich mas wiernych. Świadczy to o tym, jak bardzo Maryja nieustannie porusza serca i umysły wiernych. Zwolennicy archetypiczno-symbolicznej interpretacji wiary mówią o głębokim zakorzenieniu wiary maryjnej w sercu człowieka. Matka Jezusa jest dla nich symbolem Boskiego; w Niej miałyby znajdować się konkretny kształt archetypicznej tęsknoty i struktury duszy ludzkiej. Kierowanie oczu na Maryję dopomaga człowiekowi przy akceptacji tych pierwotnych tęsknot i doświadczeń religijnych $^{37}$. Dlatego z wielkim uznaniem należy przyjąć dokument wydany przez Kongregację ds. Kultu Bożego i Dyscypliny Sakramentów, który podaje zasady i wskazania odnośnie do pobożności ludowej i liturgii, pragnąc tym samym zharmonizować pobożność ludową z liturgią.

Autorzy dokumentu, omawiając język pobożności ludowej, wyliczają obecne w nim następujące elementy: gesty, teksty i formuły, śpiew i muzykę, obrazy, miejsca oraz świątynie ${ }^{38}$. Dyrektorium nie tylko nie ignoruje

${ }^{34}$ Por. Kongregacja Nauki Wiary, Instrukcja o chrześcijańskiej wolności i wyzwoleniu Liberatis conscientia, „Acta Apstolicae Sedis” [dalej: AAs] 79 (1987); zob. także w: W trosce o petnię wiary. Dokumenty Kongregacji Nauki Wiary 1966-1994, tłum. i oprac. Z. Zimowski, J. Królikowski, Tarnów 1995, s. 244-282.

${ }^{35}$ Tamże, 97, s. 281.

${ }^{36}$ Tamże, 98, s. 281.

${ }^{37}$ Por. F. Courth, Mariologia. Maryja, Matka Chrystusa, tłum. W. Szymona, [w:] Podręcznik teologii dogmatycznej [traktat 6-7], red. nauk. i wprow. do pol. wyd. Z. Kijas, Kraków 1999, s. $49-50$.

${ }^{38}$ Por. Congregazione per il Culto Divino e la Disciplina Dei Sacramenti, Direttorio su pietà popolare e liturgia. Principi e orientamenti, Città del Vaticano 2002, s. 25-29. 
pobożności ludowej, lecz także, doceniając bogactwo jej różnych walorów ${ }^{39}$, wymienia m.in. święte wizerunki. Dostrzega ich wartość i pomoc w przeżywaniu tajemnic wiary chrześcijańskiej. Obrazy, cieszące się dużym znaczeniem w obszarze pobożności ludowej, są znakiem zarówno wielkiego dziedzictwa artystycznego, jak i duchowej czci, którą są przez wiernych otaczane w kościołach i sanktuariach ${ }^{40}$. W tym kontekście Kongregacja przytacza uchwały II Soboru Nicejskiego, głoszące, że składanie hołdu obrazowi jest uczczeniem przede wszystkim Istoty, którą ten obraz przedstawia ${ }^{41}$.

Dokument Kongregacji ds. Kultu Bożego i Dyscypliny Sakramentów jest z pewnością próbą przyznania właściwego miejsca tak liturgii, jak i pobożności ludowej w Kościele doby posoborowej, w której dokonano niestety wielu niewłaściwych interpretacji reformacyjnych linii wytyczonych przez Konstytucję o liturgii świętej Sacrosanctum concilium. Wiele nadużyć (jak np. w Kościele w Holandii czy we Francji) wyniknęło z oszałamiającej samowoli. W trakcie nierozważnych prób reformy doszło do oderwania od zmysłu wiary całej wspólnoty Kościoła, kiedy bardziej słuchano podszeptów ducha tego świata niż Ducha Bożego. Prawie zawsze wiązało się to $\mathrm{z}$ dewastacją wszelkich form pobożności ludowej, nie tylko przez jej deprecjonowanie, ale wprost fizyczne niszczenie. Dlatego należy tylko żałować, że ten skądinąd pożyteczny dokument, który może stać się zachętą do wielu prac teologicznych, rewaloryzujących i synchronizujących ludową pobożność z liturgią, został opublikowany z takim wielkim opóźnieniem.

Podsumowując inspiracje i nowe idee, jakie wnosi ze sobą feminizacja myśli teologicznej, należy najpierw zauważyć - i jeszcze raz podkreślić ich znaczną różnorodność oraz trudność ich jednoznacznej oceny. Dlatego muszą one zostać poddane krytycznej ocenie. W rezultacie - odrzucając ekstremizm mariologiczny przejawiający się w przedstawionych powyżej niektórych stanowiskach - należy też uwydatnić głęboko wyzwalające aspekty historii Matki Jezusowej, zwłaszcza zaś Jej czynną i odpowiedzialną zgodę na plan Bożej miłości, odważny wybór dokonany przez Nią i pełne wierności oddanie się Bogu w Jego Synu, Chrystusie. Maryja z Nazaretu nie była ani kobietą biernie przyjmującą sprawy i poszczególne wydarzenia,

${ }^{39}$ Por. tamże, s. 16.

${ }^{40}$ Por. tamże, s. 27.

${ }^{41}$ H. Denzinger, A. Schönmetzer, Enchiridion symbolorum, definitionum et declarationum de rebus fidei et morum [dalej: Ds], 36. Aufl., Barcelona - Freiburg im Br. - Rom 1976, 600; Breviarium fidei. Wybór doktrynalnych wypowiedzi Kościoła [dalej: BF], oprac. S. Głowa, I. Bieda, Poznań 1988, VII, 637. 
które przynosił każdy kolejny dzień Jej życia, ani kobietą ulegającą jakiejś wyobcowanej religijności. Była raczej Tą, która odważnie obwieściła, że Bóg jest obrońcą ludzi słabych i uciskanych, że „strąca władców z tronu” (por. Łk 1, 51-53). Ta niezwykła i dzielna kobieta, sama doświadczając zarówno pewnego dostatku i radości, jak i ubóstwa i cierpień, stała się nie tylko Matką Boga, lecz także wszystkich wierzących w Jego Syna, Jezusa Chrystusa, gdyż nawet na Górze Kalwarii zachowała wiarę rodzącego się w krzyżu Kościoła (por. Iz 19, 25-27).

W Maryi ukazuje się spełniony wzór uczennicy i ucznia, w którym osoba ludzka uzyskała pełną realizację i wyraz w swojej kobiecości otwartej na Przedwiecznego oraz w żywej i płodnej relacji wzajemności z męskim bohaterem historii zbawienia - Jezusem. W kontekście mariologii profetycznej Maryja ukazuje się jako istota ludzka przed Bogiem, niewiasta, wierząca, która mówi Mu swoje „tak” i wypowiada się w wielkiej pieśni wyzwolenia, jaką jest Magnificat. Maryja to kobieta, która pozwala napełnić się łaską. Przyzwala, aby Duch Święty objął Ją swoim tchnieniem, by zajaśniała w Niej na nowo głębia tego, co ludzkie, tego, co kobiece, i głębia wiary wiążącej człowieka z tajemnicą Przedwiecznego ${ }^{42}$.

\subsubsection{Polska maryjność - fenomen nie tylko Jasnej Góry}

$\mathrm{W}$ ten interesujący kontekst rewaloryzacji kobiecości wpisuje się paradoksalnie pewien fenomen religijny. Otóż zaskakuje fakt, iż mimo postępującego zeświecczenia chrześcijańskich społeczeństw Europy Zachodniej ludowa pobożność maryjna nie słabnie. Wręcz przeciwnie, w wymiarze kultu maryjnego, jakim jest pielgrzymowanie do sanktuariów maryjnych, nasila się. Ma na to wpływ z pewnością wiele czynników różnej natury. Szacuje się, że w pielgrzymkach na świecie uczestniczy około 250 milionów osób rocznie, z tego około 150 milionów to chrześcijanie. Ocenia się, że w samej Europie około 30 milionów chrześcijan - głównie katolików poświęca swe wakacje lub urlopy na odbywanie pielgrzymek. Nie trzeba tu dodawać, że zdecydowana większość tych pielgrzymek to odwiedziny któregoś z maryjnych sanktuariów Kościoła katolickiego ${ }^{43}$.

W myśl założeń teologii kontekstualnej należy wymienić tutaj wiele niezwykłych polskich sanktuariów maryjnych. Wśród wielu pięknych i żywych

${ }^{42}$ Por. B. Forte, Maryja, ikona tajemnicy, dz. cyt., s. 30-31.

${ }^{43}$ Por. D. Ptaszycka-Jackowska, A. Jackowski, Jasnogórskie pielgrzymki w przestrzeni miasta i regionu Częstochowy, Kraków 1998, s. 7. 
miejsc kultu, takich jak np. Kalwaria Zebrzydowska, Ludźmierz, Kraków, Zakopane, Limanowa, Pasierbiec, Piotrków Trybunalski, Piekary Śląskie, Góra św. Anny, Bardo Śląskie, Gostyń, Rokitno, Obra, Biechowo, Brdów, Licheń, Leśna Podlaska, Kodeń, Leśniów, Gietrzwałd, Święta Lipka, Kalwaria Pacławska, Niepokalanów, Warszawa, Lublin, Rzeszów, Błotnica, Kałków-Godów, Sulisławice, na czoło wysuwa się Jasna Góra. Istotę i centrum tego sanktuarium stanowi przesławna ikona Świętej Bożej Rodzicielki. To w kaplicy cudownego obrazu, gdzie odczuwalna jest niezwykła i prawdziwa obecność Matki Bożej i naszej, koncentruje się żywa, niesłabnąca do Niej modlitwa, która przez Jej wszechpotężne pośrednictwo kierowana jest ona do dobrego Boga w Trzech Osobach. Tu pielgrzym doświadcza szczególnego pośrednictwa Najświętszej Maryi Panny na swojej drodze ku Ojcu Niebieskiemu. Krótko mówiąc, maryjność to podstawowa cecha Jasnej Góry. To ze względu na Świętą Maryję obecną w cudownym obrazie przychodzą na Jasną Górę setki tysięcy ludzi. W tego rodzaju ludowej pobożności odnajduje się każdy chrześcijanin. Dusza ludu łatwo identyfikuje się z Maryją w prostej, nieskomplikowanej zawiłymi prawdami religii ${ }^{44}$. Nie bez powodu św. Jan Paweł II wyznał:

Tyle razy przybywaliśmy tutaj! Stawaliśmy na tym świętym miejscu, przykładaliśmy niejako czujne pasterskie ucho, aby usłyszeć, jak bije serce Kościoła i serce Ojczyzny w Sercu Matki. Jasna Góra jest przecież nie tylko miejscem pielgrzymek Polaków z Polski i całego świata. Jasna Góra jest sanktuarium narodu. Trzeba przykładać ucho do tego świętego miejsca, aby czuć, jak bije serce narodu w Sercu Matki. Bije zaś ono, jak wiemy, wszystkimi tonami dziejów, wszystkimi odgłosami życia. Ileż razy biło jękiem polskich cierpień dziejowych! Ale również okrzykami radości i zwycięstwa! Można na różne sposoby pisać dzieje Polski, zwłaszcza ostatnich stuleci, można je interpretować wedle wielorakiego klucza. Jeśli jednakże chcemy dowiedzieć się, jak płyną te dzieje w sercach Polaków, trzeba przyjść tutaj. Trzeba przyłożyć ucho do tego miejsca. Trzeba usłyszeć echo życia całego narodu w Sercu jego Matki i Królowej! A jeśli bije ono tonem niepokoju, jeśli odzywa się w nim troska i wołanie o nawrócenie, o umocnienie sumień, o uporządkowanie życia rodzin, jednostek, środowisk,

${ }^{44}$ Por. A. A. Napiórkowski, Ekumeniczna rola Jasnej Góry, [w:] Jasna Góra w dwudziestoleciu pontyfikatu Jana Pawła II, red. Z. S. Jabłoński, Częstochowa 1999, s. 379-392. 
trzeba przyjąć to wołanie. Rodzi się ono z miłości matczynej, która po swojemu kształtuje dziejowe procesy na polskiej ziemi ${ }^{45}$.

Do najważniejszych na świecie centrów kultu religijnego, przyciągających blisko 25 milionów pątników (15 proc. pielgrzymujących chrześcijan), należą: Rzym z Watykanem (około 8 milionów), Lourdes (6 milionów), Jasna Góra w Częstochowie (4-5 milionów), Fatima (4 miliony). Jasna Góra należy więc obecnie do największych i najważniejszych ośrodków kultu religijnego na świecie (i to nie tylko w chrześcijaństwie), jest też drugim - po Lourdes - centrum kultu maryjnego ${ }^{46}$. Cechą wyróżniającą Jasną Górę spośród innych wielkich sanktuariów świata jest masowość corocznych pielgrzymek pieszych, tradycja trwająca nieprzerwanie od stuleci. W Europie Jasna Góra odgrywała i odgrywa nadal rolę ośrodka, z którego promieniują idee rozwijania lub reaktywowania pieszego pielgrzymowania. Te idee dotarły również na inne kontynenty ${ }^{47}$. Masowość pieszych pielgrzymek na Jasną Górę powoduje, że zalicza się je do ważniejszych ruchów migracyjnych ludzkości, zarówno w Polsce, jak i w Europie. Sanktuarium jasnogórskie jest równocześnie głównym centrum pielgrzymkowym Polski. Każdego roku rejestruje się tutaj liczbę pielgrzymów, która stanowi ponad 70 proc. uczestników wszystkich pielgrzymek w całym kraju ${ }^{48}$.

Podczas swojej pierwszej papieskiej pielgrzymki do Polski św. Jan Paweł II, przemawiając z jasnogórskiego szczytu, bardzo trafnie określił fenomen tego miejsca:

Przyzwyczaili się Polacy wszystkie, niezliczone sprawy swojego życia, różne jego momenty ważne, rozstrzygające, chwile odpowiedzialne, jak wybór drogi życiowej czy powołania, jak narodziny dziecka, jak matura, czyli egzamin

${ }^{45}$ Jan Paweł II, Pierwsza Pielgrzymka do Polski. Homilia wygłoszona pod szczytem Jasnej Góry, 4.06.1979.

${ }^{46}$ Niestety nie dysponujemy danymi odnośnie do największego maryjnego sanktuarium meksykańskiego w Gwadelupie.

47 Można tu wskazać wiele przykładów, jak wzorem polskiego pielgrzymowania do Częstochowy organizuje się coroczne pielgrzymki do lokalnych sanktuariów, które najczęściej posiada kopię cudownego obrazu Matki Bożej Jasnogórskiej, jak np. w amerykańskiej Częstochowie Doylestown (Pensylwania); podobna pielgrzymka odbywa się w Niemczech z Mainburga do Altötting (Bawaria). Obie pielgrzymki piesze, mające już wieloletnią tradycję, są organizowane i prowadzone przez ojców paulinów.

${ }^{48}$ Por. D. Ptaszycka-Jackowska, A. Jackowski, Jasnogórskie pielgrzymki..., dz. cyt., s. 7. 
dojrzałości, jak tyle innych... wiązać z tym miejscem, z tym sanktuarium. Przyzwyczaili się ze wszystkim przychodzić na Jasną Górę, aby mówić o wszystkim swojej Matce - Tej, która tutaj nie tylko ma swój Obraz, swój Wizerunek, jeden z najbardziej znanych i najbardziej czczonych na całym świecie - ale która tutaj w jakiś szczególny sposób jest. Jest obecna. Jest obecna w tajemnicy Chrystusa i Kościoła - uczy Sobór. Jest obecna dla każdego i dla wszystkich, którzy do Niej pielgrzymują, choćby tylko duszą i sercem, choćby tylko ostatnim tchnieniem życia, jeśli inaczej nie mogą. Przyzwyczaili się do tego Polacy. Przyzwyczaili się ich pobratymcy, sąsiedzi z różnych narodów. Coraz więcej przybywa tu ludzi z całej Europy i spoza Europy. Kardynał Prymas w takich oto słowach mówił w czasie Wielkiej Nowenny o znaczeniu częstochowskiego sanktuarium w życiu Kościoła. Pytał: „Co się stało na Jasnej Górze? Dotąd nie jesteśmy wstanie dobrze na to odpowiedzieć. Stało się coś więcej, niż zamierzaliśmy (O tak, stało się coś więcej, niż zamierzaliśmy!)... Okazało się, że Jasna Góra jest wewnętrznym spoidłem życia narodu, jest siłą, która chwyta głęboko za serce i trzyma naród cały w pokornej a mocnej postawie wierności Bogu, Kościołowi i jego hierarchii. Dla wszystkich nas była to wielka niespodzianka, że potęga Królowej Polski jest w narodzie aż tak wspaniała”. Cóż więc dziwnego, że i ja tu dziś przybywam. Przecież zabrałem z sobą z Polski na stolicę św. Piotra w Rzymie ten polski nawyk, ten „święty nawyk” Polaków, wypracowany wiarą całych pokoleń, potwierdzony doświadczeniem chrześcijańskim tylu stuleci, ugruntowany w mojej własnej duszy ${ }^{49}$.

Poza pątniczym ruchem na Jasną Górę należy odnotować inny element świadczący o wyjątkowości tego sanktuarium. Można go nazwać „fenomenem konfesjonału". To miejsce szczególnego udzielania się Boga przyciąga całe rzesze chrześcijan i wyzwala w nich przekonanie, że jedynie $\mathrm{w}$ tym miejscu może dokonać się ich pojednanie z Bogiem $\mathrm{w}$ sakramencie pokuty. Pielgrzymi pragną tak mocno doświadczyć Bożego miłosierdzia w sakramencie spowiedzi świętej, że nie odstrasza ich nawet konieczność długiego oczekiwania w kolejce. Wydaje się, że wciąż zbyt mało należnej uwagi poświęca się temu rodzajowi duszpasterskiej posługi - choć przecież w tajemnicy konfesjonału można tak bardzo posłużyć zabłąkanemu człowiekowi. Dlatego cieszy poważne studium Sprawowanie sakramentu pokuty i pojednania o. Józefa Płatka, który stara się tę tematykę dowartościować,

${ }^{49}$ Jan Paweł II, Pierwsza Pielgrzymka do Polski. Homilia wygłoszona pod szczytem Jasnej Góry, dz. cyt. 
kompetentnie ją prezentując i nie pomijając przy tym spojrzenia na Maryję jako Matkę miłosierdzia ${ }^{50}$.

Należy się tylko cieszyć i nieustannie dziękować Bożej Opatrzności za ten nadzwyczajny dar, któremu na imię Jasna Góra. Wciąż chyba bowiem niedostatecznie doceniamy to wybrane miejsce nad Wisłą, w którym Bóg szczególniej udziela się dzięki osobie i działaniu Jego Najświętszej Matki. Wśród wielu aspektów duszpasterskiego oddziaływania jasnogórskiego sanktuarium w naszym kraju należy także wskazać na elementy: ekumeniczny, historyczny, kulturowy, społeczny, międzynarodowy i patriotyczny.

\subsection{Historia rozwoju mariologii}

W miarę upływu stuleci rola i znaczenie Maryi w tajemnicy Chrystusa i Kościoła stawały się coraz częściej tematem dociekań teologów, a Jej osoba obiektem coraz bardziej ożywionego kultu wiernych, tym bardziej, że kult ten wyprzedzał systematyczną refleksję naukową. Myśliciele chrześcijańscy pierwszego tysiąclecia trwali w przekonaniu, że aby zachować w wierze oraz wyrazić w sposób właściwy i zrozumiały centralną tajemnicę Jezusa Chrystusa, trzeba mówić o Maryi, Jego Matce. W miarę rozwoju myśli teologicznej, postępującego przez drugie tysiąclecie chrześcijaństwa, narastała pewność, że nie można wyczerpująco opisać tajemnicy odkupienia człowieka, jeżeli milczy się o Maryi, będącej pierwszym i najdoskonalszym owocem zbawczego dzieła dokonanego przez Jezusa Chrystusa, Maryi, która ponadto uczestniczyła w odkupieńczych czynach Jezusa z Nazaretu i je współtworzyła, a potem aktywnie uczestniczyła w popaschalnej wspólnocie pierwotnego Kościoła.

Rozwój systematycznej refleksji nad dziejami odkupienia i spełniającego się zbawienia oraz wyprowadzanymi z nich prawdami wiary doprowadził do ukształtowania się mariologii jako odrębnej dyscypliny w zakresie teologii dogmatycznej. Proces ten trwał naturalnie przez stulecia rozwoju myśli chrześcijańskiej, ożywiany nie tylko intelektualnymi dociekaniami, lecz także modlitwą, duchowością, mistyką, herezjami i błędami, cierpieniem, objawieniami prywatnymi oraz całym szeregiem różnych form maryjności i asystencją Ducha Świętego.

${ }^{50}$ Zob. J. Płatek, Sprawowanie sakramentu pokuty i pojednania, wyd. 2, Częstochowa 2001. 
Ojcowie Kościoła mówili i pisali o Najświętszej Dziewicy w kontekście wielu różnych zagadnień teologicznych, zwłaszcza w świetle ekonomii zbawczej, łączącej się z prawdami trynitarnymi, chrystologicznymi i eklezjologicznymi oraz moralnymi. Najwięcej odniesień do Maryi znajdujemy w ich komentarzach do ksiąg Starego i Nowego Testamentu. Także scholastyka nie wypracowała odrębnego traktatu mariologicznego, choć teologowie już na wielu miejscach roztrząsali wtedy kwestie wcielenia, pośrednictwa Maryi czy niepokalanego poczęcia (Anzelm z Canterbury, 1033-1109; Bernard z Clairvaux, 1090-1153; Jan Duns Szkot, 1266-1308). Od reformy gregoriańskiej, związanej z papieżem Grzegorzem VII (1073-1085), do Soboru Trydenckiego (1545-1563) teologowie starannie oddzielali pośrednictwo Jezusa Chrystusa jako pośrednictwo odkupienia, które jest doskonałe i niezależne, od pośrednictwa stworzeń (np. Maryi). W scholastyce Maryja występowała jednak o wiele częściej jako temat kaznodziejski. Zarówno niedysponujący teologicznym wyrobieniem kaznodzieje, jak i słuchający ich lud nie dokonywali subtelnych rozróżnień. Więcej nawet, często przeciwstawiali Maryję jako miłosierną i dobrą Matkę - sprawiedliwemu i surowemu Bogu. Niektórzy wpływowi mówcy, np. Bernard z Clairvaux, nawet bardziej sławili i zalecali pośrednictwo Maryi niż Chrystusa. Pobożność ludowa połączona z ówczesnym niskim poziomem edukacji rozpowszechniła powierzchowne ujęcie prawd o Maryi i mechaniczne praktyki Jej czci, pozbawione pogłębionej intelektualnej refleksji.

Wbrew oczekiwaniom również reformacja luterańska w XVI wieku wniosła w obszar mariologii niewiele interesujących spostrzeżeń. Poprzestając na biblijnych przekazach i pierwszych Soborach, myśl reformatorska niestety nie wykształciła własnego traktatu o Maryi, ograniczając się do negacji istniejących przekazów kaznodziejskich, praktyk ludowej pobożności oraz rzymskich zaleceń.

Autorem pierwszego systematycznego wykładu mariologii okazał się hiszpański jezuita Franciszek Suárez (1548-1617), który w 1590 roku opublikował traktat Quaestiones de BVM quattuor et viginti in Summam contractae. Jednakże nazwa „mariologia” zaczęła funkcjonować wraz z dziełem Placido Nigido (ok. 1570-1640) zatytułowanym Summa sacrae mariologiae, które ukazało się w roku 1602 w Palermo. Wydany po Soborze Trydenckim Katechizm Rzymski (1566) przypominał naukę o Bożym i dziewiczym macierzyństwie Maryi oraz te elementy, które kwestionowała reformacja: wzywanie Maryi, nazywanie Jej Matką Miłosierdzia, „naszą obroną” (advocata), nową Ewą oraz uznawanie Jej szczególnych zasług przed Bogiem. 
W XVII wieku odnotować trzeba tzw. mariologię serca i pobożność ludową, którą mocno rozwijali teologowie francuscy (Pierre de Bérulle, 1575-1629; Jean-Jacques Olier, 1608-1657; Jean Eudes, 1601-1680). W tę duchowość wpisali się polscy propagatorzy nurtu niewolnictwa maryjnego: Franciszek Stanisław Fenicki (1592-1652), Jan Chomentowski, Kacper Drużbicki (1590-1662).

Z kolei w XVIII wieku mariologię serca kontynuowali francuscy kaznodzieje: Jacques-Bénigne Bossuet, Ludwik Maria Grignion de Montfort (1673-1716). Nadmiernie propagowali oni wszechpośrednictwo Najświętszej Maryi Panny. Niejednokrotnie dochodziło do nadużycia zasady „przez Maryję do Chrystusa”. W 1747 roku opublikowane w Wenecji dzieło Ludovica Antonia Muratoriego zatytułowane Della regolata divozione de' cristiani (doczekało się ono wielu wydań i kilku przekładów) rozpoczęło krytykę niewłaściwych form maryjnej pobożności. Zarzuty Muratoriego zdecydowanie odrzucał Alfons Maria de Liguori (1696-1787) w Le glorie di Maria (1750), przesadnie rozwijając elementy psychologii i spekulacji w zakresie mariologii serca.

Mariologia XIX wieku naznaczona była tematyką niepokalanego poczęcia Najświętszej Maryi Panny, co wynikało z trzech faktów: objawienia „cudownego medalika" Katarzynie Labouré (1806-1876) w Paryżu w 1830 roku, ogłoszenia przez papieża Piusa Ix (1792-1878) dogmatu niepokalanego poczęcia w Rzymie w 1854 roku i objawień maryjnych Bernadecie Soubirous (1844-1879) w 1858 roku w grocie Massabielle niedaleko Lourdes. Do rozwoju mariologii tego okresu interesujący przyczynek można odnaleźć u niemieckiego teologa Matthiasa Josepha Scheebena (1835-1888), który wypracował ideę oblubieńczego macierzyństwa Maryi. Do jego myśli nawiązali później o. Maksymilian Maria Kolbe (1894-1941) i ks. Franciszek Blachnicki (19211987). Natomiast kard. John Henry Newman (1801-1890) przedstawił koncepcję rozwoju chrześcijańskiej doktryny, uprzedzając zarzuty braku biblijnych podstaw w dogmacie o niepokalanym poczęciu Najświętszej Maryi Panny ${ }^{51}$.

Wiek xx zdominowała problematyka dogmatyzacji wniebowzięcia Maryi. Liczne komentarze, zarówno pozytywne opinie, jak i stanowiska przeciwne, pogłębiły maryjną naukę i pobożność. Protesty ze strony teologów ewangelickich, wynikające z obowiązujących ich zasad sola scriptura i solus Christus,

${ }^{51}$ Por. S. C. Napiórkowski, Mariologia, [w:] Encyklopedia katolicka [dalej: EK i numer tomu], t. 11, pod red. F. Gryglewicza, R. Łukaszyka, Z. Sułowskiego, Lublin 2006, k. 1372-1373; zob. B. Ferdek, Objawienia maryjne a znaki czasów, sM 11 (2009) nr 1, s. 47-57. 
ostatecznie sprzyjały wypracowaniu bardziej dojrzałej mariologii. Odnowiona myśl katolicka - przez sięgnięcie do źródeł biblijnych, patrystycznych, chrystologicznych, liturgicznych i ekumenicznych - podsumowała naukę o Maryi w jednym z rozdziałów Konstytucji dogmatycznej o Kościele Lumen gentium. Ów ósmy rozdział, zatytułowany Błogosławiona Maryja Dziewica, Boża Rodzicielka, w misterium Chrystusa i Kościoła, prezentuje mariologię eklezjotypiczną, podkreślając podobieństwa między Maryją i Kościołem. Jako odkupiona i dzieło łaski w tajemnicy niepokalanego poczęcia Maryja to najdoskonalszy członek Chrystusowego Kościoła. Ważnymi dokumentami mającymi istotne znaczenie dla Jej kultu okazały się dwie adhortacje Pawła vi: Signum magnum z 1967 roku oraz Marialis cultus Z 1974 roku.

Szkicując historię rozwoju mariologii, nie sposób pominąć nauczanie św. Jana Pawła II, które zawarł on nie tylko w swojej encyklice całkowicie poświęconej kwestiom maryjnym - Redemptoris Mater. O błogosławionej Maryi Dziewicy w życiu pielgrzymującego Kościoła (1987) - lecz także w swojej papieskiej i prywatnej duchowości, co wyraźnie oddają jego herb i zawołanie - Totus Tuus. Papież ten znacząco przyczynił się do szerszego rozumienia Maryi jako Matki, wyraźniej uczył o Jej pośrednictwie w pośrednictwie Chrystusa i w Duchu Świętym, a zasadę „przez Maryję do Chrystusa” uzupełnił zasadą „do Maryi przez Chrystusa” ${ }^{2}$.

Pierwsza katedra mariologii na świecie powstała na Katolickim Uniwersytecie Ameryki w Waszyngtonie w roku 1918; wkrótce potem pojawiły się następne - w Instytucie Katolickim w Paryżu oraz na większości uczelni katolickich w Rzymie. Jednym z wiodących ośrodków nauki o Maryi jest aktualnie Papieski Wydział Teologii „Marianum” w Rzymie. W Polsce pierwsza katedra mariologii została utworzona w 1958 roku na Katolickim Uniwersytecie Lubelskim. W 1999 roku założono Polskie Towarzystwo Mariologiczne. Uniwersytety katolickie i uczelnie teologiczne zaczęły traktować teologię maryjną jako odrębny traktat w całości nauczania dogmatyki - inaczej niż w teologii prawosławnej i protestanckiej. W teologii prawosławnej mariologia jest częścią chrystologii.

Wyodrębnienie mariologii z innych dyscyplin teologicznych stało się impulsem do jej dynamicznego rozwoju. Kryło jednak w sobie niebezpieczeństwo pewnej separacji tej dziedziny od pozostałych obszarów refleksji teologicznej. Stąd od Soboru Watykańskiego iı można zauważyć troskę o ściślejszą integrację mariologii z całością teologii systematycznej.

${ }^{52}$ Por. S. C. Napiórkowski, Mariologia, dz. cyt., k. 1374. 
Uwidacznia się ona również w nowym Katechizmie Kościoła katolickiego, który ukazuje Maryję całkowicie włączoną w całokształt zbawczego działania Boga i rozważa Jej posłannictwo w kontekście całego orędzia wiary chrześcijańskiej. Znaczący wkład w rozwój współczesnej mariologii nieustannie wnoszą międzynarodowe kongresy mariologiczne, które w różnych miejscach na świecie organizuje Papieska Międzynarodowa Akademia Maryjna (Pontificia Academia Mariana Internationalis, PAMI); przykładowo XIX Kongres Maryjno-Mariologiczny na Jasnej Górze w 1996 roku poświęcony był Maryi w tajemnicy zbawienia, czczonej w Duchu Świętym przez Kościoły Wschodu i Zachodu.

Obserwując współczesny dynamiczny rozwój nauki o Maryi, mówi się o kilkunastu jej rodzajach. W zależności od źródeł, stosowanych metod i wyznaczonego celu, które określają jej rodzaj i charakter, mariologię dzielimy na:

- biblijną (wydobywającą z Biblii elementy objawienia o Maryi);

- patrystyczną (opartą na nauczaniu ojców Kościoła);

- scholastyczną (rozważającą poszczególne zagadnienia, nade wszystko Boże macierzyństwo, w kontekście wcielenia);

- pozytywną (opartą na Piśmie Świętym, nauce ojców Kościoła, nauczaniu Soborów i papieży);

- przywilejów (doszukującą się tytułów chwały i ogłaszającą nowe dogmaty maryjne; przedsoborową);

- historiozbawczą (ukazującą Maryję na tle dziejów zbawienia i jej udział w tajemnicy wcielenia);

- akademicką (wykładaną na wyższych uczelniach i w seminariach duchownych);

- ludową (uprawianą przez pobożny lud);

- wyzwolenia (połączoną z teologią wyzwolenia Ameryki Łacińskiej $\mathrm{w}$ drugiej połowie $\mathrm{xx}$ wieku);

- chrystotypiczną (podkreślającą podobieństwa Maryi do Chrystusa, rodzącą pobożność wzywania Maryi w różnych potrzebach);

- eklezjotypiczną (zwracającą uwagę na podobieństwo Maryi do Kościoła, akcentującą pobożność naśladowania i zaangażowania);

- trynitarną (ukazującą relacje Maryi z Bogiem Ojcem, z Synem Bożym i Duchem Świętym) $)^{53}$;

53 Por. K. Guzowski, Maryja a Trójca Święta. Personologia trynitarna fundamentem odnowy mariologii współczesnej, sм 16 (2014) nr 1-4, s. 11-26. 
- feministyczną (skoncentrowaną na elementach żeńskich, promującą potrzebę wyzwolenia kobiet);

- symboliczną (dowartościowującą symbole biblijne odnoszone do Maryi);

- narracyjną (akcentującą opisy i doświadczenia biblijnej narracji o obecności Maryi w życiu Chrystusa i Kościoła);

- ekumeniczną (porównującą nauczanie o Maryi w różnych wyznaniach chrześcijańskich).

Podsumowując, wolno na koniec zapytać, dlaczego rozwój mariologii był nie tylko tak nierówny, lecz także tak w niektórych okresach (np. w baroku czy w XIx wieku i w pierwszej połowie wieku xx) burzliwy i przesadzony. Złożyło się na to z pewnością wiele powodów. Najbardziej fundamentalny jest chyba ten, że chrześcijaństwo - dysponując monofizycko ufarbowanym obrazem Chrystusa - postawiło Maryję w tym miejscu, które powinno przysługiwać człowieczeństwu Chrystusa. Ta tendencja doznała jeszcze wzmocnienia w późnym średniowieczu nie tylko przez zawężony obraz Chrystusa, lecz także przez niewłaściwe ujęcie Boga. Inną znaczącą tendencją, która wzmagała niewłaściwą mariologię, było przeakcentowanie znaczenia papieża i jego plena potestas. Nowożytna „papolatria” i „mariolatria" zadziwiająco wzajemnie się napędzały i stawały się specyficznie katolickimi formami, nieobecnymi w innych chrześcijańskich wyznaniach. Można powiedzieć, że słabość eklezjologii dopuściła do tych przerostów w obszarze papiestwa i maryjności. Stąd też Sobór Watykański iı wpisał papieża w całe kolegium biskupie, akcentując kolegialność, a mariologię zdecydowanie umieścił w ramach nauki o Kościele i w gmachu całej teologii systematycznej.

\subsection{Mariologia jako traktat dogmatyczny}

Mariologia jest tą częścią dogmatyki, która przedstawia w sposób systematyczny i metodycznie uporządkowany naukę Kościoła katolickiego o Matce Jezusa Chrystusa, szeroko nawiązując do innych prawd wiary i pozostałych dziedzin refleksji teologicznej. Jak każda inna dyscyplina teologii, także mariologia ma swoje granice. Nieskończoność Boga i tajemnica Jego zbawczego działania nie dadzą się zamknąć w ramach najdoskonalszego nawet systemu myśli ludzkiej. Mimo to przed każdą generacją wierzących pojawia się na nowo zadanie wyrażenia w zmieniającym się języku, kulturze 
i rozwoju cywilizacyjnym prawd niezmiennych i ponadczasowych oraz interpretowania tych prawd w konkretnym horyzoncie ludzkiego życia ${ }^{54}$.

Jeżeli mariologia jest częścią dogmatyki, to należy odpowiedzieć na pytanie, jakie miejsce zajmuje ona w systemie tej zasadniczej części teologii. Wielu teologów zwraca uwagę na szczególne powiązanie Matki Najświętszej z Chrystusem. Podkreślają oni, że to przede wszystkim z faktu Bożego macierzyństwa wypływają niezwykła rola Maryi w historii zbawienia i wszystkie Jej przywileje. Rozważając rolę Maryi w ścisłym związku ze zbawczym posłannictwem Chrystusa, skłonni są oni umieszczać naukę o Maryi w ramach chrystologii. Inni rozważają tajemnicę Maryi w odniesieniu do tajemnicy Kościoła, a w ziemskiej drodze Służebnicy Pańskiej dostrzegają wzór życia dla każdego z uczniów Chrystusa, czyli członków społeczności Kościoła. Konsekwentnie więc opowiadają się za łączeniem mariologii z traktatem eklezjologicznym. Sobór Watykański II umieścił zatem swoją mariologię w ramach Konstytucji o Kościele Lumen gentium. Nie oznacza to jednak bynajmniej, że ojcowie Soboru nie uznawali szczególnego związku mariologii z chrystologią. Sobór podkreślił szczególnie łączność Maryi z Kościołem, ponieważ nauka o Kościele była zasadniczym tematem obrad soborowych. Kolejna grupa teologów, chcąc podkreślić niezwykłe wybranie Maryi, będące dziełem Bożej łaski, uważa naukę o łasce za właściwe miejsce do rozważania Jej roli i posłannictwa. Pojawiają się także i głosy tych, którzy widzą potrzebę mocniejszego powiązania Maryi z Duchem Świętym. Stąd nie charytologia, ale pneumatologia jawi się im jako przyszłość mariologii.

Wśród wielkiej rzeszy świętych Kościoła bez wątpienia Maryja jest wyjątkową osobą, jest znakiem nadziei dla całej ludzkości i przykładem wielkości powołania nie tylko kobiety, lecz także człowieka w ogóle. Stąd bierze się uzasadnienie rozważania nauki o Maryi w kontekście antropologicznym, ale też eschatologicznym.

Spór o miejsce mariologii w systemie teologii dogmatycznej uświadamia, że Matka Jezusa to postać, w której w wyjątkowy sposób uwidaczniają się odkupieńcze i zbawcze działanie Trójjedynego Boga i personalny charakter wiary. Jako Matka Boża przynależy Ona w sposób szczególny do swojego Syna i jest pierwszym człowiekiem, który doświadczył Chrystusowego odkupienia, a więc Bożej miłości i łaski. Jako pełna łaski jest Maryja prawzorem ludzkości powołanej do zbawienia i uświęcenia w Kościele. Z ciałem

${ }^{54}$ Por. S. Budzik, Maryja w tajemnicy Chrystusa i Kościoła, wyd. II, Tarnów 1997, s. 7-9 (Academica. Instytut Teologiczny w Tarnowie, 9). 
i duszą wzięta do nieba wskazuje z kolei na eschatologiczny wymiar odkupienia dokonanego w Chrystusie i sprawowanego w Kościele zbawienia przez sakramenty.

W gruncie rzeczy współczesna nauka o Maryi została organicznie połączona ze wszystkimi aspektami teologii dogmatycznej. „Mariologia [...] stanowi punkt zwornikowy dla fundamentalnych prawd z zakresu chrystologii, nauki o łasce, eklezjologii i eschatologii"'55. Jeżeli jednak ze względów systematycznych należy jej przyznać konkretne miejsce wśród traktatów dogmatycznych, to mariologia następować powinna bezpośrednio po chrystologii i stanowić jednocześnie wprowadzenie do nauki o Kościele ${ }^{56}$.

\section{5. Źródła mariologii}

W teologii współczesnej, zwłaszcza posoborowej, istnieje kilka charakterystycznych tendencji, które mają również duże znaczenie dla rozwoju i pogłębienia systematycznej refleksji nad rolą Maryi w historii zbawienia. Chodzi tutaj po pierwsze o tzw. powrót do źródeł, czyli postulat opierania dociekań teologicznych przede wszystkim na opisach objawienia zawartych w Piśmie Świętym Starego i Nowego Testamentu:

- przekazywanych i rozwijanych przez żywą Tradycję Kościoła,

- interpretowanych autentycznie przez Urząd Nauczycielski Kościoła,

- znajdujących swój wyraz i odbicie w liturgii, w modlitwie prywatnej oraz

- w pojmowaniu wiary przez całą społeczność chrześcijańską ${ }^{57}$.

Drugą charakterystyczną tendencją współczesnej teologii jest chrystocentryzm. Chodzi tu o wiązanie poszczególnych traktatów teologicznych z ich istotnym trzonem: $\mathrm{z}$ Chrystusem, w którym objawił się w całej pełni zbawczy plan Boga wobec człowieka i świata. Skoro zaś źródłem i centrum zarówno wiary Kościoła, jak i badań teologicznych jest Chrystus, to Jego Matka nie tylko stoi bardzo blisko tego źródła i punktu centralnym całego chrześcijaństwa, lecz także jest Tą, przez pośrednictwo której Bóg rozpoczął

55 A. Skowronek, Słowo wstępne, [w:] M. Thurian, Maryja Matka Pana figura Kościoła, przeł. E. Ogiński, Warszawa 1990, s. 7 (Theotokos, 2).

${ }^{56}$ Por. K. Rahner, Mariologie, [w:] Lexikon für Theologie und Kirche. Das Zweite Vatikanische Konzil. Konstitutionen, Dekrete und Erklärungen, Bd. viI, Freiburg im Br. 1962, k. 85-86.

${ }^{57}$ Por. B. Przybylski, Mariologia w całości teologii, [w:] Gratia plena. Studia teologiczne o Bogurodzicy, pod red. B. Przybylskiego, Poznań 1965, s. 16. 
swoje zbawcze działanie w Chrystusie. „Sama historia zbawienia wyznaczyła Matce Jezusowej miejsce centralne w tym sensie, że Jej postać znalazła się w punkcie przecięcia Bożych planów zbawczych. Każdy odpowiedzialny sposób mówienia o Bogu i o Jezusie Chrystusie nie rozminie się zatem z Maryją"58. Jej dzieło i zasługi trwają nieprzerwanie i polegają na prowadzeniu ludzi każdego czasu do Chrystusa jako podstawowego i niewyczerpanego źródła wszystkich łask. Dlatego celem współczesnej teologii maryjnej, odczytującej poprawnie znaki czasu, jest powrót do źródeł, prawidłowa ich interpretacja i ukazywanie nierozerwalnej łączności Maryi z Jezusem i Jego Kościołem w dziele zbawienia za pomocą metod naukowych przyjętych w teologii ${ }^{59}$.

Wymieńmy teraz podstawowe źródła mariologii:

1. Pierwszym i zasadniczym źródłem wszystkich wypowiedzi teologicznych, a więc także mariologicznych, jest objawienie Boże zawarte w Piśmie Świętym Starego i Nowego Testamentu. Z tego źródła czerpali natchnienie do rozważań mariologicznych wielcy pisarze i ojcowie Kościoła. Szczupłość tekstów biblijnych odnoszących się do Maryi skłaniała niektórych teologów, traktujących zbyt powierzchownie Pismo Święte, do budowania mariologii jakby na marginesie danych skrypturystycznych, a protestantów - do prawie całkowitego zaniechania uprawiania teologii maryjnej. Obie tendencje nie wydają się właściwe, gdyż cechuje je redukcjonizm w podejściu do objawienia.

Charakterystyczne dla xx i xxI wieku odrodzenie i pogłębienie studiów biblijnych wywarło korzystny wpływ na mariologię i maryjność. Zwrócono uwagę na tzw. sens pełniejszy (sensus plenior) wielu tekstów, na znaczenie prorocze i figuralne wypowiedzi Starego Testamentu i Apokalipsy. Nowoczesna egzegeza pomogła odkryć nowe wymiary i aspekty biblijnego obrazu Maryi oraz Jej roli zarówno w Bożym planie zbawienia, jak i w życiu pielgrzymującego Kościoła. Dzisiejsi egzegeci katoliccy dostrzegają w Piśmie Świętym ogólny zarys całej niemal teologii maryjnej, ukazujący nie tylko i nie jedynie kolejne fakty, lecz raczej sposób, w jaki Bóg powołuje Maryję do czynnego uczestnictwa w realizacji swego planu zbawczego i darzy Ją łaską swego wybrania ${ }^{60}$.

2. Szczególnie ważnym źródłem, z którego wyrasta mariologia, jest Tra dycja. W teologii chrześcijańskiej przez Tradycję rozumie się zarówno

${ }^{8}$ A. Skowronek, Słowo wstępne, dz. cyt., s. 7.

59 Por. tamże, s. 16.

${ }^{60}$ Por. B. Przybylski, Mariologia w całości teologii, dz. cyt., s. 17. 
treść przekazywanego Bożego objawienia od Chrystusa przez apostołów i świadków tradycji aż po dziś dzień, samą czynność przekazywania objawienia, jak i postulowane przez nie i zrealizowane zachowania ludzkie. Tradycja jest $\mathrm{z}$ jednej strony gwarancją wierności zbawczemu orędziu Chrystusa, z drugiej zaś - świadectwem dynamizmu chrześcijańskiej wiary, która winna być ustawicznie przekazywana kolejnym pokoleniom. Nie podaje ona prawd nowych, ale wyjaśnia i pogłębia zrozumienie objawienia zawartego w Piśmie Świętym - przy czym nie tylko rozważa to, co objawienie głosi explicite, lecz także wnika w to, co mieści się w nim implicite. Współcześnie mówimy o rozwoju rozumienia treści objawionych zawartych w Tradycji. Zmienia się zatem nie tyle samo objawienie, co jego ludzkie rozumienie. Szczególnym autorytetem w dziedzinie przekazywania Tradycji cieszą się ojcowie Kościoła. Wypowiedzi wielu z nich są świadectwem niezwykłej intuicji teologicznej $\mathrm{w}$ dziedzinie prawd maryjnych, których zdefiniowanie nastąpiło znacznie później (niepokalane poczęcie, wniebowzięcie). Tradycja nie kończy się wraz z okresem patrystycznym, ale przez wysiłek teologów i normatywne wypowiedzi Magisterium Kościoła stale się wzbogaca i rozwija.

3. Kolejnym źródłem mariologii jest Urząd Nauczycielski Kościoła. Przysługuje mu funkcja kierownicza i nadrzędna we wszystkich badaniach z zakresu teologii. Zasadniczym zadaniem Magisterium Kościoła jest troska o zachowanie depozytu wiary i czuwanie nad czystością jej przekazu. Nowe idee i próby rozwiązań, które przedstawiają teologowie, są odrzucane przez Magisterium bądź znajdują jego aprobatę, o ile harmonijnie włączają się w strukturę teologiczną kościelnego wyznania wiary i dają się pogodzić z zasadniczym nurtem wielowiekowej Tradycji Kościoła.

Podporządkowanie teologów Urzędowi Nauczycielskiemu ma zarówno aspekt negatywny, jak i pozytywny. Ten pierwszy polega na gotowości poddania osądowi Kościoła własnych przemyśleń i wypowiedzi, drugi zaś na uwzględnianiu w pracach badawczo-konstruktywnych wskazań i pouczeń Urzędu Kościoła. Jest to szczególnie ważne w dziedzinie teologii maryjnej, do której dokumenty papieskie i inne wypowiedzi Magisterium tak często powracają, precyzując pewne prawdy i tłumacząc coraz wszechstronniej tajemnicę posłannictwa Matki Bożej. Z kolei Magisterium Kościoła winno chętnie korzystać z pomocy osiągnięć rzetelnych badań teologicznych, stanowiących niejako pomost między Urzędem Nauczycielskim a problemami współczesnego człowieka i osiągnięciami współczesnych nauk, zarówno humanistycznych, jak i przyrodniczych. 
4. Litu rg i a, jako przyjęty przez Kościół wyraz jego wiary, należy do podstawowych źródeł teologii i ma duże znaczenie w kształtowaniu się dogmatów maryjnych. Jednak nie można twierdzić, że czwarte źródło mariologii w swoich modlitwach i obrzędach jest normą dla wiary. Zbyt często pomija się w teologii modlitwę, a przecież teologia ma znajdować swoje zwieńczenie właśnie w doksologii, czyli prywatnym i zbiorowym uwielbieniu Trójcy Świętej.

Uzasadniano to wcześniej znaną już w starożytności chrześcijańskiej zasadą lex orandi - lex credendi. Przy tej zasadzie pozostały dziś jedynie Kościoły Wschodu. Chrześcijanie Zachodu przyjęli odmienny tok rozumowania - to nie liturgia kształtuje wiarę, ale nasza wiara przejawia się w liturgii. Kult Maryi jest czymś wtórnym wobec prawd wiary. Bardziej pierwotną sprawą jest wiara, która objawia się i uzewnętrznia w formach czci, którą oddajemy Najświętszej Maryi Pannie. Potwierdziła to ostatecznie encyklika Piusa xı Mediator Dei z 1947 roku. Papież wskazał w niej na błędne przypisywanie liturgii roli probierza prawd wiary. Według niego należy odrzucić aksjomat lex orandi - lex credendi. Pius xiI zauważa, że:

kult, który Kościół składa najlepszemu i wszechmogącemu Bogu, jest według wyraźnych i zwięzłych słów Augustyna nieustannym wyznaniem wiary katolickiej oraz aktem nadziei i miłości: „przez wiarę, nadzieję i miłość”, tak pisze, „mamy Bogu cześć oddawać". W liturgii świętej wyznajemy otwarcie i wyraźnie wiarę katolicką, nie tylko celebrując tajemnice święte, sprawując Ofiarę i udzielając Sakramentów, ale także odmawiając lub śpiewając „Symbol” który jest znakiem i jakby dowodem osobistym chrześcijan, a wreszcie czytając księgi święte powstałe pod natchnieniem Ducha Świętego lub inne dokumenty. Cała liturgia więc zawiera wiarę katolicką, jako publiczne świadectwo o wierze Kościoła. $Z$ tej to przyczyny, ilekroć chodziło o definicję jakiejś prawdy objawionej przez Boga, Papieże i Sobory, czerpiąc z tzw. „źródeł teologicznych”, nierzadko również z liturgii św., przytaczali argumenty. Tak na przykład postąpił Nasz Poprzednik, niezapomnianej pamięci Pius IX, gdy ogłosił dogmat o Niepokalanym Poczęciu Najświętszej Maryi Panny. Podobnie prawie i Kościół i Ojcowie, gdy roztrząsano wątpliwości i spory na temat jakiejś prawdy, nie omieszkali szukać światła w czcigodnych obrzędach przekazanych przez starożytne wieki. Stąd owo sławne i czcigodne powiedzenie: „Legem credendi lex statuat supplicandi” ${ }^{61}$.

${ }^{61}$ Paweł vi, Encyklika Mediator Dei o Świętej Liturgii, część I, rozdz. III. 
Tylko elementy boskie są niezmienne, natomiast elementy ludzkie - uwidaczniające się w liturgii - mogą, a nawet muszą podlegać zmianie.

Sam fakt wprowadzenia jakiejś prawdy o Matce Bożej do oficjalnego kultu Kościoła powszechnego jest znaczącym wyzwaniem dla teologii, ale też i jej potwierdzeniem. Dlatego liturgia świąt maryjnych, ich powstanie, zasięg i znaczenie w różnych Kościołach i obrządkach zasługują na szczególną uwagę mariologów. Liturgia, ukazując zwykle rzeczywistość nadprzyrodzoną $\mathrm{w}$ formie modlitewnej lub symbolicznej, wyjątkowo zawiera jakieś oświadczenie formalne. Dlatego nie da się przeprowadzić prawidłowej i obiektywnej egzegezy tekstów liturgicznych bez uwzględnienia ducha epoki i środowiska ich pochodzenia, źródeł, z których je zaczerpnięto, i właściwych wyjaśnień.

5. Kolejne źródło - sensus fidelium, czyli z mysł wiary ludu chrześcijańs ki e go - jest nadprzyrodzonym i intuicyjnym pojmowaniem przez człowieka wierzącego, będącego pod działaniem Ducha Świętego, poszczególnych prawd wiary w jedności z całym Kościołem. Lud wierzący wyczuwa w swoim głębokim i autentycznym życiu wewnętrznym, kim jest Maryja i jakie miejsce wyznaczył Jej Bóg w swoim zbawczym planie. Kierowani tym odczuciem wierzący oddają cześć Matce Bożej, nie wchodząc w zawiłe rozróżnienia i subtelności dyskusji teologicznych. Magisterium Kościoła uznaje ten zmysł wiary za świadectwo dawane prawdzie, ale równocześnie kieruje nim i krytycznie ocenia jego przejawy. Popiera to, co w nim pozytywne, a odrzuca zawsze pewne możliwe niewłaściwości i przejaskrawienia ${ }^{62}$.

Współczesna topika teologiczna, to znaczy nauka o „miejscach”, w których znajdują się argumenty dla teologii, wymienia szereg innych źródeł, przy czym nie istnieje jakiś powszechnie przyjęty ich podział. Stanisław Celestyn Napiórkowski kładzie nacisk również na źródła „niezobiektywizowane", do których zalicza znaki czasu, człowieka jako źródło i jako adresata teologii, wiarę, i to zarówno w punkcie wyjścia, jak i w tworzeniu teologii, oraz wprowadzoną przez Jana Pawła II w maryjnej encyklice Redemptoris Mater nową kategorię - doświadczenie osób i wspólnot chrześcijańskich ${ }^{63}$. Miejsca teologicznego poznania można z pewnością rozszerzyć jeszcze o wiele elementów, np. kulturę, literaturę lub sztukę.

${ }^{62}$ Por. S. Budzik, Maryja w tajemnicy Chrystusa i Kościoła, dz. cyt., s. 12-17.

${ }^{63}$ Por. tamże, s. 13nn; por. S. C. Napiórkowski, Jak uprawiać teologię, Wrocław 1994, s. 3948. Por. W. Życiński, Historyczne doświadczenie osób i wspólnot chrześcijańskich, [w:] Jan Paweł II, Matka Odkupiciela. Tekst i komentarze, red. S. C. Napiórkowski, Lublin 1993, s. 81-89. 
Do wzmiankowanych już tendencji we współczesnej mariologii (powrotu do źródeł i chrystocentryzmu) wypada jeszcze zaliczyć co najmniej trzy dalsze, a mianowicie: eklezjalność, odpowiedzialne postulaty teologii feministycznej (których nie należy mylić z emancypacją) oraz nasilające się tendencje do budowania mariologii integralnej. 


\section{Pismo Święte o Maryi}

Wszystko, co w chrześcijańskiej wierze ma znaczenie, ma i musi mieć podstawę w Piśmie Świętym. Tę zasadę zgodnie przyjmują katolicka i ewangelicka teologia, nawet jeśli występują w nich różnice co do stopnia intensywności wyraźnych odniesień w Biblii, pomijając już nawet ich interpretację. Potwierdzenie istnienia prawd objawienia na kartach Pisma Świętego staje się gwarancją, że treści wiary nie są wynikiem pobożnej świadomości, emocjonalnych potrzeb czy też postulatów ludzkiej refleksji, ale wypływają z historycznego objawienia się Boga Ojca, który otworzył się na człowieka poprzez Bożego Syna i w darze Ducha Świętego. Zdecydowane opieranie się na Piśmie Świętym, które jest przecież i ponadkonfesyjne, sprzyja też ekumenicznemu zbliżeniu wszystkich wyznawców Chrystusa. Nie do utrzymania jest bowiem teza, że Maryja dzieli chrześcijan. Matka Jezusa łączy nas bardziej, niż nam się wydaje.

Trzeba uczciwie przyznać, że Pismo Święte nie mówi zbyt wiele o Maryi (Miriam, Mariam) z Nazaretu, córce Joachima i Anny. Niemniej te lapidarne, krótkie stwierdzenia słowa Bożego o Niej kryją w sobie wielką głębię. Życie i osoba Matki naszego Pana okazują się zatem spowite tajemnicą, którą próbujemy nieustannie i od nowa zgłębiać - Niewieście tej przysługują przecież tak znaczące miejsce i ogromna rola w historii ludzkiego zbawienia ${ }^{1}$.

W Starym Testamencie prawie wszystkie teksty odnoszone do Maryi muszą być rozumiane w sensie alegorycznym, typicznym bądź duchowym. Są to: $\mathrm{Rdz} 3,15 ; 3,20 ; 25,21-34$; 27, 1-45; Lb 17, 23-25; $1 \mathrm{Krl} 2$, 19-20; Tb 13, 13-15; Jdt 9, 8-12; 13, 18-20; 15, 9; 16, 5; Hi 38, 12-13; Ps $45,10-18 ; 110,1-3 ; 116,16 ; 132,8$; Prz $6,20-21 ; 8,17 ; 8,22-36 ; 9,1-6 ; 15,20 ; 30,11 ; 31,20-22$; Pnp 2, 2-6; 2, 16; 3, 4; 3, 6; 4, 1-16; 5, 1-2; 5, 5; 6, 1-10; 8, 5-14; Mdr 8, 10; 8, 13; 8, 17-18; Syr 3, 4; 5, 11-14; 24, 3-22; 40, 1; Iz 7, 10-15; 11, 1-2; 66, 10-14; Mi 5, 1-3; Za 4, 1-14; Ml 3, 1. 
Maryja w zwiastowaniu Pańskim przyjęła powołanie do Bożego macierzyństwa, jako Matka Jezusa i pierwsza uczennica Mesjasza towarzyszyła $\mathrm{Mu}$ w ziemskim życiu i misji aż po Jego ofiarę na krzyżu, a następnie uczestniczyła w tworzeniu się Kościoła, doświadczając chrystofanii - kiedy Zmartwychwstały na nowo zwoływał wspólnotę uczniów i uczennic - i daru Zesłania Ducha Świętego. Ze względu na Jej pełną wiary obecność przy Jezusie Chrystusie nazywana jest Ona pierwszą wierzącą, Oblubienicą, Służebnicą i Jego towarzyszką. Po zakończeniu swojego ziemskiego życia została wzięta $z$ duszą i ciałem do nieba, aby odtąd wstawiać się za wierzącymi w Chrystusa i wszystkimi dziećmi Boga.

Jakkolwiek Maryja jest postacią biblijną i historyczną, to główne prawdy wiary związane z Jej osobą i posłannictwem były w Kościele przez wieki stopniowo odkrywane i formułowane przez wspólnotę wierzących ${ }^{2}$. Poddajmy teraz analizie podstawowe dla mariologii źródło objawienia, jakim są teksty Starego i Nowego Testamentu.

\subsection{Teksty typiczne Starego Testamentu}

Z tego, że poszczególne księgi biblijne stanowią kanon Pisma Świętego, wynika, że należy traktować je jako całość zawierającą pełnię objawienia Bożego. Pomiędzy poszczególnymi elementami tej całości istnieją związki i zależności, zwłaszcza między Starym a Nowym Testamentem. Od czasów patrystycznych znana jest reguła: Vetus in Novo patet. Novum in Vetere latet - Stary Testament staje się w pełni zrozumiały w świetle Nowego, Nowy Testament zaś jest ukryty w Starym.

Perspektywa chrystologiczna Nowego Testamentu pozwala w tekstach Starego Przymierza odczytać więcej, niż dopuszcza to literalna jedynie interpretacja poszczególnych wypowiedzi. Metodę taką stosowali już autorzy pism Nowego Testamentu, wskazując, że liczne fakty z życia Jezusa były wypełnieniem starotestamentalnych obietnic Bożych. W takim znaczeniu wolno więc mówić o tekstach maryjnych w Starym Testamencie - choć mamy właściwie zaledwie kilka miejsc w tej części Pisma Świętego, które możemy jedynie pośrednio i w sposób typiczny odnieść do Matki Jezusa. Wychodząc poza sens dosłowny, a posługując się perspektywą chrystologiczną, wolno

2 Por. E. Kasjaniuk, Maryja, [w:] EK, t. 12, Lublin 2008, k. 1; por. S. De Fiores, Maria. Madre di Gesù. Sintesi stolico-salvifica, Bologna 1998, s. 35-52. 
wskazać kilka znaczących miejsc odnoszących się do Maryi. Są to: Protoewangelia - Niewiasta i Jej potomstwo miażdżące głowę węża: Rdz 3, 15; Arka i Namiot Spotkania - Maryja jako miejsce spotkania Jahwe ze swoim ludem: Wj 40, 2-3; Służebnica Pańska: Est 4, 17; 2 Sm 14, 6-19; Rt 2, 13; Jdt 11, 5; Matka Emmanuela: Iz 7, 14; Córa Syjonu (rozumiana też jako personifikacja Jerozolimy): Iz 1, 8; 3, 16; Za 9, 9; Reszta Izraela: Ez 9, 14; Iz 6, 12-13; Jr 52, 15; Rodząca: Mi 5, 1-43.

Omówmy teraz szerzej tych zasadniczych siedem starotestamentalnych miejsc biblijnych, które w sensie typicznym odnosimy do Maryi, i poddajmy je krótkiej analizie.

Proto e wa ngeli a $\left(\mathrm{Rdz}_{3}, 15\right)$ : „Wprowadzam nieprzyjaźń między ciebie a niewiastę, pomiędzy potomstwo twoje a potomstwo jej: ono zmiażdży ci głowę, a ty zmiażdżysz mu piętę". Tekst ten nosi zaszczytną nazwę Protoewangelii, gdyż jest pierwszą zapowiedzią Dobrej Nowiny o zwycięstwie nad złem. Maryjną interpretację tekstu utrwalił przekład Wulgaty, w którym występuje zwrot ipsa conteret („ona zmiażdży”), zamiast ipsum conteret („ono zmiażdży”). Zawartość teologiczna tej wypowiedzi jest jednak identyczna w obu przypadkach. To zapowiedź ostatecznego wyzwolenia spod przemocy szatana i zła, w którą człowiek popadł przez swój upadek. Zwycięstwo to będzie dziełem potomstwa niewiasty. Tą niewiastą w sensie dosłownym jest Ewa, w sensie typicznym zaś Maryja, Matka Mesjasza.

Arka i Namiot Spotkania (Wj 40, 2-3). Namiot Spotkania tworzyły elementy wewnętrzne i zewnętrzne. Do tych pierwszych zaliczamy: stół chlebów, świecznik i ołtarz kadzenia, do tych drugich zaś: ołtarz całopalenia, kadź i dziedzińce. Izrael w Namiocie Spotkania przechowywał Arkę Przymierza, do której dochodziły jeszcze przebłagalnia, cheruby i zasłona. Lud był przekonany, że jest to miejsce spotkania z Jahwe. W sensie typicznym miejscem spotkania ludzkiej i Boskiej natury jest łono Maryi, która okaże się Rodzicielką Mesjasza. Maryja jest zatem miejscem spotkania Boga z ludem Nowego Przymierza.

Określenie Służebnica Pańska (Est 4, 17; 2 Sm 14, 6-19; Rt 2, 13; Jdt 11, 5), które wielokrotnie pojawia się w Starym Testamencie, w Magnificat wyraźnie jest odniesione do Maryi. Ona zresztą sama tak się opisuje. W tym wyrażeniu znajdujemy gotowość do pełnienia woli Jahwe, mimo trudności, nierozumienia jej czy też nawet pewnych ciemności.

\footnotetext{
3 Por. O. da Spinetoli, Maryja w Biblii, przeł. A. Tronina, Niepokalanów 1997, s. 11-50.
} 
Córa Syjonu (Iz 1, 8; 3, 16; Ps 45, Za 9, 9) - określenie to bywa najczęściej rozumiane jako personifikacja Jerozolimy. Prorok głosił: „Córa Syjonu stała się niczym budka w winnicy, jak chatka w polu ogórkowym, jak oblężone miasto” (Iz 1, 8); „Raduj się wielce, Córo Syjonu, wołaj radośnie, Córo Jeruzalem! Oto Król twój idzie do ciebie, sprawiedliwy i zwycięski. Pokorny - jedzie na osiołku, na oślątku, źrebięciu oślicy" (Za 9, 9). Jednakże w sposób pośredni wolno ten tekst odnieść do Maryi, Matki Jezusa.

Matka Emmanuela $(I z 7,14)$. Prorocy Starego Testamentu zapowiadali, że przyszły Mesjasz narodzi się z Dziewicy. Prototyp Maryi znajdujemy w znaku Panny, kiedy prorok Izajasz zapowiada znak Emmanuela: „I znowu Pan przemówił do Achaza tymi słowami: «Proś dla siebie o znak od Pana, Boga twego, czy to głęboko w Szeolu, czy to wysoko w górze!». Lecz Achaz odpowiedział: "Nie będę prosił i nie będę wystawiał Pana na próbę». Wtedy rzekł [Izajasz]: «Słuchajcie więc, domu Dawidowy: Czyż mało wam naprzykrzać się ludziom, iż naprzykrzacie się także mojemu Bogu? Dlatego Pan sam da wam znak: Oto Panna pocznie i porodzi Syna, i nazwie Go imieniem Emmanuel. Śmietanę i miód spożywać będzie, aż się nauczy odrzucać zło, a wybierać dobro" (Iz 7, 10-15). Funkcjonują tutaj zależności: obietnica - spełnienie, antycypacja - urzeczywistnienie, sens przenośny - sens właściwy. Do tej ważnej starotestamentalnej zapowiedzi "Oto Panna pocznie i porodzi Syna i nazwie Go imieniem Emmanuel” nawiązują w swoich Ewangeliach Mateusz i Łukasz, widząc w niej zapowiedź dziewiczego poczęcia Jezusa.

Reszta Izraela (Ez 9, 14; Iz 6, 12-13; Jr 52, 15). Temat „Reszty Izraela” pojawia się przede wszystkim $\mathrm{w}$ okresie po powrocie narodu $\mathrm{z}$ wygnania, przyjmując charakter eschatologicznego znaku. „Reszta”, oznaczająca zasadniczo część ubogiej ludności, resztę ludu pozostałego w mieście, składa się przede wszystkim z biednych, słabych i upokorzonych, którzy nie oczekują niczego od siebie, lecz wszystkiego od Jahwe. W nich Bóg obiecuje spełnić swoje obietnice i przeprowadzić swoje władanie. „Czy znowu mamy przekraczać twoje polecenia i spowinowacać się z tymi obrzydliwymi narodami? Czy nie rozgniewasz się na nas aż do wytępienia, tak że nie pozostanie Reszta ocalonych? Panie, Boże Izraela, to łaska Twoja, żeśmy tym razem pozostali ocaleni. Otośmy przed Tobą obarczeni winą. Zaprawdę, niepodobna wobec tego ostać się przed Tobą»” (Ez 9, 14). „Pan wyrzuci ludzi daleko, tak że zwiększy się pustynia wewnątrz kraju. A jeśli jeszcze dziesiąta część [ludności] zostanie, to i ona powtórnie ulegnie zniszczeniu jak terebint lub dąb, z których pień tylko zostaje po zwaleniu. Reszta jego [będzie] świętym 
nasieniem” (Iz 6, 12-13). Jako „uboga Jahwe” Maryja ucieleśnia w sobie świętą „Resztę Izraela”.

Rodząca (Mi 5, 1-4): „A ty, Betlejem Efrata, najmniejsze jesteś wśród plemion judzkich! Z ciebie mi wyjdzie Ten, który będzie władał w Izraelu, a pochodzenie Jego od początku, od dni wieczności. Przeto [Pan] wyda ich aż do czasu, kiedy porodzi mająca porodzić. Wtedy reszta braci Jego powróci do synów Izraela. Powstanie On i paść będzie mocą Pańską, w majestacie imienia Pana Boga swego. Osiądą wtedy, bo odtąd rozciągnie swą potęgę aż po krańce ziemi. A Ten będzie pokojem”. Współczesny Izajaszowi, Micheasz, zapowiada wybawiciela, który pod wieloma względami jest podobny do Emmanuela (por. Iz 7, 11). Micheasz prorokuje o królu - pasterzu z rodu Dawida, jaki narodzi się w przyszłości, lecz będzie wywodził się „od początku, od dni wieczności” oraz „paść będzie mocą Pańską, w majestacie imienia Pana Boga swego". Do proroctwa Micheasza nawiązuje Ewangelia Mateusza w opisie pokłonu Mędrców ze Wschodu (Mt 2, 6) podkreślając, że Betlejem ma być miejscem narodzenia Mesjasza. Przy mesjańskiej interpretacji tekstu „mająca porodzić” oznacza Maryję, Matkę Mesjasza.

Istnieje ponadto wiele tekstów biblijnych, które ojcowie i pisarze Kościoła oraz liturgia odnoszą do Matki Bożej. Nie tyle są to próby wydobycia głębszego sensu Pisma Świętego, ile biblijne ilustracje do refleksji teologicznej nad rolą Maryi w dziejach zbawienia oraz dla pogłębienia wiary Kościoła w Jej posłannictwo. Przykładem mogą być tu liczne fragmenty z Pieśni nad Pieśniami, np. 4, 7: „Cała piękna jesteś, przyjaciółko moja, i nie ma w tobie skazy”, albo tekst o Mądrości Bożej z Księgi Przysłów 8, 22-36: „Pan mnie stworzył, swe arcydzieło, przed swymi czynami, od dawna”. Istnieje również wiele obrazów starotestamentalnych, w których liturgia Kościoła rozpoznaje Matkę Bożą, a które zebrane są w Litanii Loretańskiej. Szczególne znaczenie mają te obrazy, których podstawą są aluzje Ewangelistów, dostrzegających w Maryi Córę Syjonu czy Arkę Przymierza.

\subsection{Maryja w świetle Nowego Testamentu}

Aby zrozumieć i właściwie ocenić rolę Najświętszej Maryi Panny w dziejach zbawienia, należy sięgnąć naturalnie do Pisma Świętego Nowego Testamentu, gdyż to tutaj odnajdziemy Jej pełniejszą postać. Wprawdzie teksty mówiące o Matce Jezusa nie zajmują w nim wiele miejsca (jest to zaledwie dwadzieścia perykop ewangelicznych), są jednak bogatsze treściowo 
i znaczeniowo. Rozważając świadectwo maryjne Nowego Testamentu, należy pamiętać o tym, co Chrystus w Ewangelii św. Jana przyrzekł swoim uczniom: że Duch Święty doprowadzi ich do pełnego poznania prawdy, i to na gruncie objawienia przyniesionego przez Chrystusa (por. J 14, 26; 15, 26). Wnikliwe prześledzenie historii dogmatu ukazuje, że wszystko, co jest w maryjnej teologii decydujące, wypływa w swej istocie z danych Pisma Świętego. Istotnym zadaniem Kościoła jest ciągłe odczytywanie na nowo orędzia biblijnego o Maryi i troska o jego coraz głębsze zrozumienie ${ }^{4}$.

\subsection{1. Świadectwo św. Pawła: bezimienna rodząca}

Najstarszym świadectwem biblijnym o Matce Jezusa jest fragment Listu św. Pawła do Galatów, napisanego najprawdopodobniej w latach 56-57: „Gdy nadeszła pełnia czasu, zesłał Bóg Syna swego, zrodzonego z niewiasty, zrodzonego pod Prawem, aby wykupił tych, którzy podlegali Prawu, abyśmy mogli otrzymać przybrane synostwo" ( $\mathrm{Ga} 4,4-5)$. Tekst ten bywa często określany jako mariologia w zarodku i mariologia anonimowa, ponieważ Paweł w tym zwięzłym tekście nie wymienia nawet imienia matki Jezusa.

Ten najstarszy chronologicznie tekst Nowego Testamentu stwarza przesłanki do późniejszego ujęcia prawdy o Boskim macierzyństwie Maryi. Stwierdza bowiem, że Jezus jest Synem Bożym, a równocześnie prawdziwym człowiekiem zrodzonym z kobiety (ziemskiej matki) i podporządkowanym prawu żydowskiemu. Cel wcielenia Syna Bożego jest soteriologiczny (zbawczy): członkowie narodu wybranego mają zostać wyzwoleni z niewoli prawa i obdarzeni przybranym synostwem Bożym. Podkreślając narodzenie z niewiasty i pod Prawem, św. Paweł pragnie uwypuklić wspólnotę losów Syna Bożego z narodem żydowskim, z którego wyszedł, jako z ludem wybranym. W tym, że List do Galatów wymienia matkę, a nie wspomina ojca, niektórzy egzegeci dopatrują się aluzji do dziewiczego narodzenia Chrystusa. Inni zauważają natomiast, że Apostoł Narodów nie usiłuje odpowiedzieć na pytanie, w jaki sposób dokonało się wcielenie. Jego główną intencją jest podkreślenie paradoksalnej na pozór identyczności Syna Bożego, istniejącego przed założeniem świata i równego Bogu, i człowieka-Jezusa,

${ }^{4}$ W odróżnieniu od Starego Testamentu w Nowym Testamencie znajdują się teksty poświęcone Matce Chrystusa, które możemy rozumieć w dosłownym sensie. Są to: Mt 1, 2-17; 1, 18-25; Mk 3, 31-35; 6, 1-6; Łk 1, 26-38; 1, 39-56; 2, 4-20; 2, 21-39; 2, 41-55; J, 2, 1-11; 19, 25-27; Dz 1, 14; 2, 1-4; Ga 4, 4-5; Ap 2, 7; 11, 1-15; 11, 19; 12, 1-17; 20, 1-3. Por. S. De Fiores, Maria. Madre di Gesù. Sintesi stolico-salvifica, dz. cyt., s. 52-106. 
narodzonego w czasie, narodzonego z niewiasty, jak każdy inny człowiek. Tekst wskazuje jednak wyraźnie na to, że Bóg, zsyłając swojego Syna, posłużył się niewiastą jako matką.

Wyrażenie „pełnia czasu” nawiązuje do wypełnienia się mesjańskich obietnic Bożych złożonych narodowi izraelskiemu i podkreśla, że wcielenie Syna Bożego jest wydarzeniem historycznym. Ta wskazówka ważna jest również i dla teologii maryjnej. „Pełnia czasu” to konkretne miejsce w dziejach, w którym Maryja pojawia się w historii zbawienia i wypełnia swoją jedyną i niepowtarzalną misję

\subsubsection{Ewangelia św. Marka: Maryja w rodzinie ludzkiej i eschatycznej}

Następnym - w kolejności chronologicznej - źródłem biblijnym maryjnej teologii jest Ewangelia św. Marka. Uchodzi ona zresztą wśród pozostałych za najstarszą; powstała w latach sześćdziesiątych I wieku. Dwa jej fragmenty mówią o Matce Jezusa.

Tekst pierwszy (Mk 3, 31-35), występujący u wszystkich synoptyków (Mt 12, 46-50; Łk 8, 19-21), opowiada o przyjściu krewnych pragnących rozmawiać z Jezusem. Zatrzymali się oni przed domem, w którym nauczał. „Właśnie tłum ludzi siedział wokół Niego, gdy Mu powiedzieli: «Oto Twoja Matka i bracia na dworze pytają się o Ciebie». Odpowiedział im: «Któż jest moją matką i którzy są braćmi?». I spoglądając na siedzących dokoła Niego, rzekł: «Oto moja matka i moi bracia. Bo kto pełni wolę Bożą, ten mi jest bratem, siostrą i matką»".

Poprawność rozumienia tego tekstu zapewnia przeciwstawienie, które oddają dwa wyrażenia: na ze wn ątrz („na dworze”) - w środku („dookoła Niego"). Te dwa kontrastowe pojęcia uosabiają dwie formy pokrewieństwa: pokrewieństwo cielesne i duchowe. Rodzina z krwi (naturalna, ludzka) jest na zewnątrz, a rodzina duchowa (nadprzyrodzona, Boża) znajduje się przy Jezusie.

Fragment Mk 3, 31-35 przedstawia Maryję w gronie rodzinnym. Na początku działalności mesjańskiej Jezusa Maryja i Jego bliscy mieli problemy z zaakceptowaniem Jego misji i sposobu jej prowadzenia. Mieli trudności z określeniem tożsamości swojego krewnego z Nazaretu. Odpowiedź Jezusa prowadzi do odsunięcia na plan dalszy związków rodzinnych dla podkreślenia szczególnej łączności z Bogiem i z tymi, którzy pełnią Jego

\footnotetext{
5 Por. S. Budzik, Maryja w tajemnicy Chrystusa i Kościoła, dz. cyt., s. 19-21.
} 
wolę. Wrażenie to pogłębia fakt, że nieco wcześniej, w wersecie 21, jest mowa o bliskich, którzy nie rozumieją Jego misji („odszedł od zmysłów”) i pragną Go od niej odwieść. Ewangelista nie mówi jednak o tym, że Maryja należała do tych „bliskich”. Poza tym słowa Jezusa mogą być również interpretowane jako pochwała Maryi, która będąc matką w porządku naturalnym, zalicza się jednocześnie, a nawet przede wszystkim, do tych, którzy pełnią wolę Bożą. W takim znaczeniu słowa Jezusa odkrywałyby nieznaną stojącym wokoło słuchaczom prawdziwą wielkość Maryi.

Głównym przesłaniem tekstu jest ukazanie cech nowej rodziny eschatologicznej, którą jest Kościół i którą gromadzi wokół siebie Jezus. W tej rodzinie decydujące znaczenie mają nie więzy krwi, ale łączność duchowa. Należeć mogą do niej ci, którzy - idąc za Jezusem - pełnią wolę Bożą; w ten sposób mogą wejść do grona Jego najbliższych. Wypowiedź Jezusa sugeruje, aby w Maryi podkreślać nie to, co Ją wyróżnia ze względu na szczególną więź z Synem, ale raczej to, co łączy Ją z tymi, którzy na Jej wzór przyjmują słowo Boże i wypełniają je w swoim życiu. Matka i bracia Jezusa stoją na zewnątrz, „na dworze”, a eschatyczna wspólnota - Kościół - znajduje się wewnątrz domu, jest „już” zebrana wokół Boskiego Nauczyciela. Wolno wnioskować, że omawiana perykopa ukazuje przede wszystkim Maryję w eschatycznej rodzinie Chrystusa, nie wykluczając Jej z biologicznych więzi z Jezusem. Ostatecznie trzeba powiedzieć, że cały sens tekstu Mk 3, 31-35 nie usuwa krewnych Jezusa z Jego rodziny eschatycznej ${ }^{6}$. Okazuje się, iż naturę przewyższa łaska, a człowieczeństwo - Boskość. Jednak łaska nie znosi cielesności, ale ją wywyższa. Podobnie i Boskość nie deprecjonuje człowieczeństwa, ale je przekształca i uszlachetnia. Z prawdy wypływa moc, ale z łaski - zbawcza skuteczność.

$\mathrm{W}$ drugim fragmencie (Mk 6, 1-6) Ewangelista opisuje niedowiarstwo mieszkańców Nazaretu. Podkreśla, że poznanie Jezusa według ciała (historycznego) nie zawsze prowadzi do poznania Jego pełnej osoby i duchowego wymiaru Jego posłannictwa: „CZy nie jest to cieśla, syn Maryi, a brat Jakuba, Józefa, Judy i Szymona? Czyż nie żyją tu u nas także Jego siostry?» I powątpiewali o Nim".

Zastanawia w tekście, że Jezus jest określony jako s y n Mary i. Według zwyczaju żydowskiego człowieka określa się nade wszystko imieniem jego ojca (np. J 21, 15: „Szymonie, synu Jana”). Marek nie wspomina natomiast nigdzie imienia Józefa. Pozostali synoptycy, mimo że obaj znają tekst

${ }^{6}$ Por. E. Adamiak, Traktat o Maryi, Warszawa 2006, s. 28 (Dogmatyka, 2). 
Marka i posługują się nim, wskazują w tym kontekście również na ojca (Mt 13, 55: „Czyż nie jest on synem cieśli?”; Łk 4, 22: „Czyż nie jest to syn Józefa?”). Określenie „syn Maryi“ używane było w późniejszym czasie z nacechowaniem ujemnym, jako insynuacja nieprawego pochodzenia (tak jest w Talmudzie), względnie jako wskazówka dziewiczego narodzenia (jak np. w Koranie). Inni egzegeci uważają, że brak imienia ojca należy tłumaczyć tym, że Józef już nie żył, albo uznają to za świadectwo naturalnej i czysto ludzkiej interpretacji dzieła Jezusa. Można więc przypuszczać, że w Markowej relacji chodzi przede wszystkim o przedstawienie negatywnej reakcji mieszkańców Nazaretu. Jednak w głębszej warstwie znaczeniowej kryje się tu aluzja do prawdy wiary o dziewiczym narodzeniu Syna Bożego i tym samym jest to odniesienie do Maryi i stanu, w jakim porodziła Jezusa.

Z tekstów Markowych wynika, że Maryja musiała przejść swoistą drogę do wiary w Syna. Można dostrzec stopniowe przechodzenie od wiary niedoskonałej typu żydowskiego, o zabarwieniu politycznym, do osobowej wiary w Mesjasza, Sługę Jahwe, zbawiającego świat przez krzyż. Jest oczywiste, że to przechodzenie, owo wydoskonalanie się w wierze, nie dokonywało się bez bólu i cierpienia; jednak tego niezrozumienia nie wolno rozciągać na całe życie Maryi. Już np. po weselu w Kanie Galilejskiej Maryja i bracia Jezusa należeli do wspólnoty wierzących (por. J 2, 12$)^{7}$.

\subsubsection{Ewangelia św. Mateusza: Maryja w rodowodzie Jezusa}

Ewangelia św. Mateusza - w odróżnieniu od Ewangelii św. Marka, stanowiącej jej główne źródło i podstawę - wykazuje wyraźniejsze zainteresowanie rolą i znaczeniem Maryi w dziele zbawienia. Świadczy o tym przede wszystkim tzw. Ewangelia dziecięctwa (Mt 1-2). Ewangelista ukazuje Maryję przez pryzmat osoby Józefa, wpisując Ją w Dawidowy rodowód (genealogię) Jezusa. Zasadniczą prawdą, jaką Mateusz podkreśla w odniesieniu do Maryi, jest jednak dziewicze poczęcie Jezusa.

Ewangelia Mateusza rozpoczyna się od rodowodu (Mt 1, 2-17) ukazującego Jezusa jako dziedzica obietnic Bożych przekazanych Abrahamowi i Dawidowi. Pod względem literackim genealogia Jezusa jest midraszem, w którym chodzi o interpretację wydarzeń. Fragment Mt 1-2 nie jest historią ani legendą. Ma rdzeń historyczny i domaga się odpowiedzialnej interpretacji teologicznej. Interesujące jest to, że linia rodowodu urywa się

7 Por. J. Kudasiewicz, Maryja w Biblii. Obraz Maryi w ujęciu synoptyków, [w:] EK, t. 12, Lublin 2008, k. 3. 
w najważniejszym punkcie (Mt 1, 16). Autor natchniony unika stwierdzenia, że Jezus pochodzi od Józefa, podkreśla tylko macierzyństwo Maryi. Ta godna uwagi wypowiedź, że Maryja jest matką Jezusa, Józef zaś nie jest Jego biologicznym ojcem, zostaje dodatkowo potwierdzona przez to, że Mateusz, wspominając w rodowodzie cztery inne kobiety (co w ówczesnym judaizmie było dość nietypowe), używa zawsze tego samego określenia, np. „Booz był ojcem Obeda, a matką była Rut" (Mt 1,5). W wypadku Jezusa jest inaczej. Należałoby oczekiwać stwierdzenia: „Józef był ojcem Jezusa, a matką była Maryja”. Pojawiają się natomiast słowa: „Jakub był ojcem Józefa, męża Maryi, z której narodził się Jezus, zwany Chrystusem”. Mimo że Jezus zostaje włączony w drzewo rodowe Dawida jako (adoptowany, czyli prawnie uznany) syn Józefa, to jednak Ewangelista podkreśla z naciskiem, że zawdzięcza On swoje istnienie i posłannictwo samemu Bogu.

Drugi fragment pierwszego rozdziału Mateuszowej Ewangelii dziecięctwa (Mt 1,18-25) służy do wyjaśnienia nadprzyrodzonego poczęcia Jezusa. Maryja była według żydowskiego prawa poślubiona Józefowi. Oficjalne zaślubiny zostały najprawdopodobniej poprzedzone zaręczynami. Formalnym ich potwierdzeniem było spisanie umowy, które miało skutki prawne. Ojciec Maryi musiał zatroszczyć się o posag, który miała wnieść do domu przyszłego męża. Maryja mieszkała, prawdopodobnie ze względu na swój młody wiek, w domu rodziców. Kiedy „znalazła się brzemienną za sprawą Ducha Świętego", Józef zamierzał oddalić Ją potajemnie. Dopiero nadprzyrodzona interwencja - „Józefie, synu Dawida, nie bój się wziąć do siebie Maryi, twej Małżonki, albowiem z Ducha Świętego jest to, co się w Niej poczęło” (Mt 1, 20 - tzw. „Zwiastowanie Józefowi”) - powoduje, że Józef decyduje się na wprowadzenie Maryi do swojego domu i uznanie, drogą adopcji, Jej dziecka za swoje ${ }^{8}$.

W tym krótkim tekście dwa razy (Mt 1, 18. 20) występuje określenie „za sprawą Ducha Świętego", który oznacza tutaj, wobec braku rodzajnika w tekście greckim, twórczą moc Bożą. Mateusz podkreśla nadprzyrodzone pochodzenie Chrystusa, a zarazem dziewictwo Maryi. Dodatkowym argumentem na potwierdzenie tego faktu - obcego żydowskim oczekiwaniom mesjańskim - jest przypomnienie obietnicy proroka Izajasza: „Oto Dziewica pocznie i porodzi Syna, któremu nadadzą imię Emmanuel, to znaczy Bóg z nami” (Mt 1, 23). W niejasnym zarysie Izajaszowego proroctwa rozpoznaje Ewangelista postać Maryi, tajemniczą Dziewicę, Tę, która poczęła

8 Por. S. Haręzga, Małżeństwo Maryi i Józefa, sm 11 (2009) nr 3, s. 11-2o. 
dziewiczo przez Ducha Świętego bez udziału człowieka9. Ewangelie dość skąpo relacjonują przy tym zachowanie Józefa. Obszerniejszy opis postaci tego niezwykłego mężczyzny jako małżonka Maryi i opiekuna Jezusa rzuciłby więcej światła także i na samą Maryję i historię zbawienia. Należy słusznie przypuszczać, iż w przyszłych wiekach chrześcijaństwa dokona się wielkie odkrycie tego „przeczystego Stróża Dziewicy” i „Żywiciela Syna Bożego".

Podkreślenie dziewiczego narodzenia, które Ewangelista rozumie jako fakt historyczny, jakkolwiek możliwy do przyjęcia tylko przez wiarę, jest argumentem na rzecz Bożego synostwa Jezusa - ma więc charakter chrystologiczny. Z istoty Jezusowego posłannictwa wynikają jednak konsekwencje również dla Maryi, Matkę Jezusa, wybranej przez Boga do spełnienia szczególnych zadań w dziele zbawienia. Należałoby zaznaczyć tutaj także rolę św. Józefa: Maryja jest przecież przedmiotem szczególnej troski Boga i troskliwej opieki swego świętego małżonka (por. Mt 2, 13-23). Ma Ona również udział w hołdzie, który narody pogańskie, w osobach Mędrców ze Wschodu, składają Jezusowi (Mt 2, 11).

Z Markowego przekazu (Mk 3, 21) Mateusz eliminuje aluzję do niewiary krewnych w posłannictwo Jezusowe (Mt 12, 46-50; por. Mt 13, 53-58). Maryja wie o niezwykłym pochodzeniu Jezusa oraz Jego nadprzyrodzonym posłannictwie i z wiarą otwiera się na Jego działalność. Ewangelista podkreśla z drugiej strony, że również członków rodziny Jezusa dotyczy skierowana do uczniów wypowiedź, że tylko przez wiarę w Jego Boskie posłannictwo i przez zasłuchanie się w Jego słowo można wejść do królestwa Bożego.

Reasumując, należy stwierdzić, że przekaz Mateuszowy jest świadectwem budzącego się zainteresowania pierwotnego Kościoła funkcją Matki Jezusa w dziele odkupienia. Ewangelista, redagując swoje dzieło, natrafia na ślad tego zainteresowania, starszego niż jego Ewangelia, i pogłębia je przez swoją teologiczną interpretację. Chociaż akcentowanie faktu dziewiczego narodzenia służy przede wszystkim ukazaniu niezwykłości zbawczego działania Boga, to jednak z drugiej strony autor tego dzieła dostrzega, że w dziejach zbawienia Dziecię i Jego Matka są ze sobą nierozerwalnie związani.

9 Zob. Iz 7, 13-14: „Rzekł Izajasz: «Słuchajcie więc, domu Dawidowy: Czyż mało wam naprzykrzać się ludziom, iż naprzykrzacie się także mojemu Bogu? Dlatego Pan sam da wam znak: Oto Panna pocznie i porodzi Syna, i nazwie Go imieniem Emmanuel»”. 


\subsubsection{Ewangelia św. Łukasza: Maryja wiary}

Obraz Matki Bożej ze szczególną wyrazistością nakreślił św. Łukasz. Jego Ewangelia, powstała w latach 80-90, była przeznaczona dla chrześcijan nawróconych z pogaństwa - dlatego najbardziej zasadniczą postawą Maryi jest w niej wi a ra. W porównaniu z Ewangeliami Mateusza i Marka kobiety odgrywają u św. Łukasza znaczniejszą rolę. Wstęp do Ewangelii (Łk 1, 1-4) podkreśla przywiązanie autora do tradycji i podaje metodę, jaką autor posłużył się podczas redakcji dzieła ${ }^{10}$. W tej Ewangelii wyróżniamy następujące fragmenty traktujące o Maryi: zwiastowanie, nawiedzenie, Magnificat, narodzenie, ofiarowanie, znalezienie Jezusa w świątyni (Łk 1, $26-2,52)$. Teksty te znajdują się więc ponownie w Ewangelii dziecięctwa ${ }^{11}$.

Ewangelia ta ma jednak zupełnie inną kompozycję niż Mateuszowa. W odróżnieniu od pierwszego Ewangelisty, który przedstawia historię Jezusa niejako od strony św. Józefa, Łukasz kreśli bieg wydarzeń z punktu widzenia Maryi. W Łukaszowej Ewangelii dziecięctwa historia Jezusa przeplata się z historią Jana Chrzciciela: autor opisuje zapowiedź poczęcia obydwu z poleceniem nadania im specjalnych imion, które mają znaczenie zbawcze. Imię „Jezus" - hebrajskie Jehoszua, Jeszua - oznacza "Jahwe jest zbawieniem, ratunkiem”, „Bóg jest zbawieniem”, „Bóg zbawia”. Z kolei imię „Jan” oznacza „Bóg jest łaskawy”, „Jahwe się zmiłował”'. Narodziny obu synów mają być związane ze znakami ich wyjątkowego posłannictwa. W centrum relacji znajdują się obie matki (Maryja i Elżbieta), dlatego też część pierwsza kończy się ich spotkaniem. Druga część, opisująca narodzenie Jana i późniejsze o sześć miesięcy narodzenie Jezusa, kończy się dialogiem Jezusa z Jego Matką w świątyni. Do opisu włączone są hymny oraz wskazówki nawiązujące do Starego Testamentu i podkreślające zbawczy charakter tych wydarzeń ${ }^{13}$.

${ }^{10}$ Por. J. Auer, Kleines Dogmatik, Bd. 4/2, Jesus Christus - Heiland der Welt. Maria - Christi Mutter im Heilsplan Gottes, Regensburg 1988, s. 404.

${ }^{11}$ Istnieje spora literatura apokryficzna Nowego Testamentu, która jest próbą wypełnienia braku informacji na temat tego, co się działo z Jezusem w Jego najmłodszych latach, np. Ewangelia Dzieciństwa Tomasza, Ewangelia Dzieciństwa Arabska, Ewangelia Dzieciństwa Ormiańska, Ewangelia Dzieciństwa Łacińska.

${ }^{12}$ Lukasz tak pisze o synu Elżbiety i Zachariasza: „Dziecię rosło i umacniało się w duchu i przebywało na miejscach pustynnych aż do czasu ukazania się swego w Izraelu” (Łk 1, 80).

${ }_{13}$ Por. O. Knoch, Maria in der Heiligen Schrift, [w:] Handbuch der Marienkunde, Bd. I, Hrsg. W. Beinert, H. Petri, Regensburg 1984, s. 41. 
Pierwszy fragment dotyczący Maryi to zwiastowanie:

W szóstym miesiącu posłał Bóg anioła Gabriela do miasta w Galilei, zwanego Nazaret, do Dziewicy poślubionej mężowi, imieniem Józef, z rodu Dawida; a Dziewicy było na imię Maryja. Anioł wszedł do Niej i rzekł: „Bądź pozdrowiona, pełna łaski, Pan z Tobą, błogosławiona jesteś między niewiastami”. Ona zmieszała się na te słowa i rozważała, co miałoby znaczyć to pozdrowienie. Lecz anioł rzekł do Niej: „Nie bój się, Maryjo, znalazłaś bowiem łaskę u Boga. Oto poczniesz i porodzisz Syna, któremu nadasz imię Jezus. Będzie On wielki i będzie nazwany Synem Najwyższego, a Pan Bóg da Mu tron Jego praojca, Dawida. Będzie panował nad domem Jakuba na wieki, a Jego panowaniu nie będzie końca”. Na to Maryja rzekła do anioła: „Jakże się to stanie, skoro nie znam męża?”. Anioł Jej odpowiedział: „Duch Święty zstąpi na Ciebie i moc Najwyższego osłoni Cię. Dlatego też Święte, które się narodzi, będzie nazwane Synem Bożym. A oto również krewna Twoja, Elżbieta, poczęła w swej starości syna i jest już w szóstym miesiącu ta, która uchodzi za niepłodną. Dla Boga bowiem nie ma nic niemożliwego”. Na to rzekła Maryja: „Oto Ja służebnica Pańska, niech Mi się stanie według twego słowa!". Wtedy odszedł od Niej anioł (Łk 1, 26-38).

Łukaszowa perykopa, zawierająca zapowiedź poczęcia i narodzin Jezusa, należy bezsprzecznie do najważniejszych nowotestamentalnych tekstów o Matce Pana. Bibliści wyróżniają w obrazie zwiastowania pięć elementów: 1. przybycie anioła, 2. lęk osoby nawiedzanej, 3. zwiastowanie narodzin syna, 4. wyrażenie obiekcji, 5. zapowiedź znaku. Scena zbudowana jest na wzór znanych ze Starego Testamentu opisów Bożego orędzia, skierowanego np. do Abrahama (zapowiedź narodzin Izaaka, por. Rdz 17, 1-22) czy Samsona (por. Sdz 13, 1-7). Łukasz umieszcza to wydarzenie w szóstym miesiącu od poczęcia Jana Chrzciciela, w miasteczku galilejskim Nazaret. Osobami niezwykłego dialogu są: Maryja Dziewica, poślubiona Józefowi, z rodu Dawida, i archanioł Gabriel, znany już w Starym Testamencie z posłannictwa o charakterze mesjańskim. Należy tu wspomnieć, że narracji Łukaszowej nie wolno traktować w taki sposób, jakby była ona zapisem fizycznej rozmowy między Maryją a aniołem. Ogólnie uznaje się dzisiaj, że Bóg potrafi objawić człowiekowi pewne prawdy bez pośrednictwa sygnałów odbieralnych przez osoby trzecie. Określając Łukaszową Ewangelię dziecięctwa jako historyczną, teologia stwierdza, że miały miejsce opisane w niej wydarzenia, natomiast nie wypowiada się wcale na temat historyczności każdego 
przytoczonego w tekście słowa czy użytego wyobrażenia. Nie wolno tracić z oczu formy literackiej zastosowanej przez Łukasza, gdyż pisał on dla chrześcijan pierwszego stulecia i starał się odpowiedzieć na ich pytania, nie zaś na te, które zadajemy w xxi wieku ${ }^{14}$.

Najnowsze badania egzegetyczne, które opis zwiastowania uważają wprost za formułę przymierza lub przynajmniej dopatrują się w nim wyraźnych aluzji do wydarzeń z góry Synaj, uznają scenę zwiastowania z Łk 1 za początek Nowego Przymierza. Zdaniem egzegetów odpowiedź Maryi na słowa wysłannika Bożego - określona przez Elżbietę jako słowa wiary (Łk 1, 45) jest paralelna do odpowiedzi wiary Ludu Bożego na słowa pośrednika w czasie zawierania przymierza. Wspólnota Izraela wyraża swoją zgodę wiary innymi słowami niż Maryja, ale zawierającymi tę samą istotną treść. Stąd fiat Maryi jako Jutrzenki Nowego Przymierza ma taki sam charakter. Można tu się odwołać do tekstów przymierza synajskiego:

1. „Wtedy cały lud jednogłośnie powiedział: Uczynimy wszystko, co Pan nakazał" (Wj 19, 8; por. 24, 3. 7; Jr 42, 20).

2. „My chcemy służyć Panu [...] i głosu Jego chcemy słuchać” (Joz 24, 21. 24).

3. „Według orzeczenia twego powinniśmy postąpić” (Ezd 10, 12; por. Ne 5, 12).

Interpretację zwiastowania jako inauguracji Nowego Przymierza potwierdzają również pewne elementy kontekstu. Jako znak wszechmocy Bożej anioł obwieszcza Maryi poczęcie i narodziny Jana Chrzciciela $\mathrm{z}$ bezpłodnej Elżbiety (por. Łk 1, 36). Ponadto literacka struktura sceny zwiastowania odzwierciedla strukturę przymierza. W starotestamentowych opisach przymierza spotyka się zawsze dwa elementy: mowę pośrednika przymierza (w Wj 19, 4-6 jest to Mojżesz) i odpowiedź ludu (Wj 19, 8). Te same dwa elementy - mowę Gabriela jako pośrednika przymierza i odpowiedź Maryi - dostrzec można w zwiastowaniu ${ }^{15}$.

Pierwsza część zwiastowania mówi o Maryi i Jej niezwykłym wybraniu. „Bądź pozdrowiona” (gr. chaire) można też przetłumaczyć jako „raduj się". Jest to kluczowe słowo proroków zapowiadających radość mesjańską. Tekst ten przywołuje w pamięci obraz Córy Syjonu, będącej personifikacją ludu wybranego, występujący u proroka Sofoniasza (So 3, 14-17)

\footnotetext{
${ }^{14}$ Por. J. McHugh, Maryja w Nowym Testamencie, przeł. A. Czarnocki, Niepokalanów 1998, s. $53-57$.

${ }^{15}$ Por. J. Kudasiewicz, Odkrywanie Ducha Świętego. Medytacje biblijne, Kielce 1998, s. 125127.
} 
i Zachariasza (Za 9, 9). Ewangelista identyfikuje nową Córę Syjonu z Maryją, którą Gabriel określa jako kecharitomene, pełną łaski, ukształtowaną przez Łaskę, przedmiot szczególnego upodobania Jahwe. Wyrażenie „Pan z Tobą" podkreśla, że Maryi powierzone zostanie wielkie zadanie w dziele odkupienia i zbawienia.

Druga część sceny zwiastowania wyjaśnia ludzkie i Boskie pochodzenie Mesjasza. Będzie on Synem Maryi: „Oto poczniesz i porodzisz Syna, któremu nadasz imię Jezus”. Łukasz nawiązuje tu z pewnością do Iz 7, 14 - i tu, i tam Dziewica (według Septuaginty) ma począć i porodzić Syna oraz nadać Mu imię wyrażające prawdę, że Jahwe jest zbawieniem. Będzie On jednocześnie Synem Najwyższego, czyli Synem Bożym. Słowa „Pan Bóg da Mu tron Jego praojca, Dawida” nawiązują do proroctwa skierowanego do Dawida przez proroka Natana (2 Sm 7, 12-16). Pytanie Maryi „Jakże się to stanie, skoro nie znam męża?” podkreśla raz jeszcze dziewicze poczęcie i prowadzi do odpowiedzi Gabriela: „Duch Święty zstąpi na Ciebie i moc Najwyższego osłoni Cię”. Cień Boży, padający na Maryję, przypomina obłok, który w Starym Testamencie był znakiem obecności Bożej (por. Wj 40, 34). Ten obłok osłaniał „swoim cieniem Arkę Przymierza, podczas gdy Chwała Boga, to znaczy sam Bóg, ogarniał Jej wnętrze. Teraz Maryja będzie przedmiotem tej obecności Pana Chwały: będzie nią ogarnięta i napełniona" ${ }^{\prime 16}$.

Ostatnie słowa sceny zwiastowania wskazują, że jakkolwiek wybranie Maryi jest dziełem łaski, to jednak Ona sama przez swoją gotowość przyjęcia Bożych planów i przez poddanie się woli Bożej aktywnie i świadomie współpracuje ze Stwórcą w dziele zbawienia. Dziewicze macierzyństwo wypływa więc nie tylko z nadprzyrodzonego działania łaski, lecz także z wiary Maryi i Jej wolnej decyzji. Dotykamy tu zresztą głębokiej tajemnicy współdziałania wszechmocy Bożej i wolności człowieka. Maryja ma swoją drogę wiary. Dlatego nie bez racji twierdzimy, że dojrzewała Ona w wierze (np. „Czemuś nam to uczynił?”, Łk 2, 48). Maryja i Józef wielokrotnie nie rozumieli słów i zachowań Jezusa nie tyle w odniesieniu do Jego Bożego synostwa, ile do zapowiedzi tajemnicy paschalnej. Także żaden $\mathrm{z}$ apostołów nie odgadł profetycznego wymiaru osoby i życia Jezusa oraz analogii między Jego życiem a Starym Testamentem ${ }^{17}$.

${ }^{16}$ R. Laurentin, Matka Pana. Traktat mariologiczny, przeł. R. Siemieńska, Częstochowa 1989, s. 31.

${ }_{17}$ Por. W. Życiński, Droga Maryi u boku Syna Najwyższego, SM 15 (2013) nr 1-4, s. 303-325. 
Wydarzenie zwiastowania znajduje swoją kontynuację w nawiedzeniu:

W tym czasie Maryja wybrała się i poszła z pośpiechem w góry do pewnego miasta w [pokoleniu] Judy. Weszła do domu Zachariasza i pozdrowiła Elżbietę. Gdy Elżbieta usłyszała pozdrowienie Maryi, poruszyło się dzieciątko w jej łonie, a Duch Święty napełnił Elżbietę. Wydała ona okrzyk i powiedziała: „Błogosławiona jesteś między niewiastami i błogosławiony jest owoc Twojego łona. A skądże mi to, że Matka mojego Pana przychodzi do mnie? Oto skoro głos Twego pozdrowienia zabrzmiał w moich uszach, poruszyło się z radości dzieciątko w moim łonie. Błogosławiona jesteś, któraś uwierzyła, że spełnią się słowa powiedziane Ci od Pana" (Łk 1, 39-45).

W nawiedzeniu, czyli spotkaniu obu matek pozostających w służbie swych synów (Łk 1,39-56), Łukasz podkreśla, że Jezus przewyższa pod każdym względem Jana Chrzciciela. Dlatego Elżbieta, mimo że znacznie starsza od Maryi, wita Ją jako Matkę swego Pana. Tak oto porządek duchowy bierze górę nad zwyczajem. Jezus objawia się w tej scenie już jako Kyrios - Pan, zarówno w stosunku do Elżbiety, jak i Jana („Pójdziesz przed Panem, torując Mu drogi", Łk 1, 76). Tytuł ten wskazuje nie tylko na godność mesjańską Jezusa, lecz także na tajemnicę Jego Boskości. Również w tej scenie dochodzi do głosu mesjańska radość Ludu Bożego: tam, gdzie są Jezus i Jego Matka, świat napełnia się radością. Boży Duch obdarowuje stworzenie szczęściem otwiera się nadzieja na nową rzeczywistość.

Scena nawiedzenia nawiązuje do opisu przeniesienia Arki Przymierza z 2 Sm 6, 1-14. Istnieje szereg paralel słownych, geograficznych i tematycznych między tymi dwoma opisami. Widać wyraźnie, że Łukasz traktuje Maryję jak żywą Arkę Przymierza, która kryje w swoim wnętrzu Boga i Pana. Matka Jezusa otrzymuje z ust Elżbiety potwierdzenie otrzymanej od Boga obietnicy. Maryja została obdarzona wielką godnością. Ze względu na owoc Jej łona przysługuje Jej pierwszeństwo przed wszystkimi niewiastami. Wypowiedź Elżbiety jest nawiązaniem do pochwały Judyty („Błogosławiona jesteś, córko, przez Boga Najwyższego, spomiędzy wszystkich niewiast na ziemi", Jdt 13, 18) oraz błogosławieństwa Mojżesza skierowanego do ludu Izraela („Błogosławiony będzie owoc twego łona”, Pwt 28, 4). Końcowe słowa Elżbiety wskazują na wiarę Maryi, stanowiącą kontrast z pełną wątpliwości postawą Zachariasza. Cała scena jest świadectwem rodzącej się w już pierwotnej gminie chrześcijańskiej autentycznej pobożności maryjnej. A ponieważ nie jest ona zaszczepiana sztucznie ani nie jest obcym 
wytworem, musi być widziana jako proces, nacechowany naturalnością i dojrzewaniem w czasie, co staje się też potwierdzeniem jej prawdziwości.

Trzecim fragmentem Łukaszowej Ewangelii, którego nie można w żadnym wypadku pominąć, analizując zwiastowanie i nawiedzenie, jest Magnificat:

Wtedy Maryja rzekła: „Wielbi dusza moja Pana, i raduje się duch mój w Bogu, moim Zbawcy. Bo wejrzał na uniżenie Służebnicy swojej. Oto bowiem błogosławić mnie będą odtąd wszystkie pokolenia, gdyż wielkie rzeczy uczynił mi Wszechmocny. Święte jest Jego imię - a swoje miłosierdzie na pokolenia i pokolenia [zachowuje] dla tych, co się Go boją. On przejawia moc ramienia swego, rozprasza [ludzi] pyszniących się zamysłami serc swoich. Strąca władców z tronu, a wywyższa pokornych. Głodnych nasyca dobrami, a bogatych z niczym odprawia. Ujął się za sługą swoim, Izraelem, pomny na miłosierdzie swoje - jak przyobiecał naszym ojcom - na rzecz Abrahama i jego potomstwa na wieki". Maryja pozostała u niej około trzech miesięcy; potem wróciła do domu (Łk 1, 46-56).

Odpowiedzią Maryi na słowa Elżbiety jest uwielbienie Boga - utkane niemal w całości ze starotestamentalnych tekstów, nawiązujące jednak przede wszystkim do pieśni Anny, matki Samuela (1 Sm 2, 1-10: „Raduje się me serce w Bogu"). Hymn Magnificat to jakby uwertura do Kazania na Górze. Pierwsza część wskazuje na wybór Maryi przez Boga, będący skutkiem wszechmocy i miłosierdzia Bożego (Łk 1, 46-50), część druga zaś opisuje zbawcze dzieła Boga wobec narodu wybranego (Łk 1, 51-55), przy czym wybranie Maryi jest kluczem do zrozumienia wybrania ludu izraelskiego. Maryja wyśpiewuje swoją radość za dar powołania i uczestniczenia w Bożych planach, składając uwielbienie Jahwe. Bóg ciągle powołuje ludzi wyróżniających się wiarą i świętością, dzięki czemu powstaje duchowy lud, zwany „ubogimi Jahwe”, do których Maryja zalicza samą siebie. To z tego ludu narodzi się Syn Boży (por. Łk 1, 48-53).

Na Magnificat trzeba też spojrzeć $\mathrm{z}$ dwóch punktów widzenia. Bóg Ojciec $\mathrm{z}$ jednej strony jest sprawcą wielu wydarzeń w życiu Maryi. Od pierwszej chwili Jej istnienia przemienia Ją swoją łaską, napełnia miłością, która jest wyborem i upodobaniem („znalazłaś łaskę u Boga”, Łk 1, 30), zapewnia Jej pomoc w realizacji powołania na matkę Syna Bożego („Pan z tobą”, Łk 1, 28), w osobie Anioła sam do Niej przychodzi, objawia się Jej i zapowiada czasy mesjańskie. Z drugiej strony - Maryja odpowiada Bogu: „Niech mi się stanie według Twego słowa” (Łk 1,38). Wobec Ojca Niebieskiego przyjmuje 
postawę ufności i nadziei. Dlatego dokonuje się w Niej największy cud historii zbawienia - Boże macierzyństwo ${ }^{18}$.

Z opisu narodzenia (Łk 2, 1-20), które Łukasz umieszcza w konkretnej sytuacji historycznej regionu i całego świata, dowiadujemy się, że Maryja jest poślubiona Józefowi i że oczekuje dziecka. Samo narodzenie wspomniane jest jednym krótkim zdaniem: „Porodziła swego Syna pierworodnego” $(Ł k$ 2, 7). Słowo „pierworodny” (por. również Łk 2, 23) nie jest tu użyte dla odróżnienia Go od pozostałego rodzeństwa, lecz dla podkreślenia praw i przywilejów, jakimi cieszył się pierworodny syn, według Prawa poświęcony Bogu (por. Wj 13, 11-16). Na pokłon pasterzy, którzy znaleźli „Maryję, Józefa i Niemowlę, leżące w żłobie" (Łk 2, 16), wszyscy reagują zdziwieniem. Jedynie o Maryi jest powiedziane, że „zachowywała wszystkie te sprawy i rozważała je w swoim sercu" (Łk 2, 19). Ta postawa Maryi, poświadczona jeszcze raz na końcu rozdziału $(Ł k 2,51)$ oraz w scenie zwiastowania (Łk 1, 29), jest - według Łukasza - postawą, jakiej Jezus domaga się od swoich uczniów.

Następne dwie perykopy opisują relację Jezusa do świątyni i Prawa. Jeżeli opis narodzenia jest niejako komentarzem do Pawłowego określenia "zrodzony z niewiasty”, to opis ofiarowania ( $€ k$ 2, 22-40) komentuje druga część zdania św. Pawła: „zrodzony pod Prawem”. Proroctwo, które przy ofiarowaniu w świątyni wypowiada Symeon, składa się z dwóch części. Pierwsza (Łk 2, 29-32) to hymn Nunc dimittis, Kantyk Symeona, sławiący Jezusa jako Tego, który przynosi zbawienie Boże. Druga część (Łk 2, 3435) dotyczy zarówno Jezusa, jak i Maryi. Już sama kompozycja wskazuje na przyporządkowanie Maryi do Jezusa oraz ich nierozdzielność. Los Syna, „któremu sprzeciwiać się będą" (Łk 2,34), ma być również losem Jego Matki, której „duszę miecz przeniknie” (Łk 2, 35).

Łukaszowa Ewangelia dziecięctwa kończy się opisem znalezienia Jezusa w świątyni (Łk 2, 41-52) na progu Jego prawnej pełnoletniości. Po raz pierwszy zabiera On głos - wyrasta niejako tym samym z dzieciństwa i przejmuje odpowiedzialność za własne życie. Główną rolę w perykopie odgrywa Matka Jezusa. To Ona, a nie Józef, czyni Jezusowi wymówki: „Synu, czemuś nam to uczynił?” (Łk 2, 48). Odpowiedź Jezusa spotyka się z niezrozumieniem, ale tylko o Maryi ponownie jest powiedziane, że „chowała wiernie wszystkie te wspomnienia w swoim sercu" (Łk 2, 51).

${ }_{18}$ Por. H. Witczyk, Bóg Ojciec a Maryja w tajemnicy zwiastowania, sm 1 (1999) nr 2, s. 113131. 
Inne wypowiedzi maryjne św. Łukasza to: rodowód Jezusa (por. Łk 3, 23-38), wspomnienie o wizycie krewnych Jezusa (Łk 8, 19-21), perykopa z kobietą z tłumu, wielbiącą Matkę Jezusa (por. Łk 11, 27-28). W Dziejach Apostolskich $(1,14)$ Maryja występuje natomiast w gronie uczniów przygotowujących się przez modlitwę na Zesłanie Ducha Świętego. Jest to ostatnia scena z Jej życia odnotowana na kartach Pisma Świętego. Obecność Maryi wśród członków pierwszej gminy chrześcijańskiej jest znakiem, że Jej miłość macierzyńska skierowała się ku rodzącemu się Kościołowi, któremu Maryja będzie towarzyszyć na drogach jego pielgrzymowania.

Na podstawie powyższych rozważań można stwierdzić, że Łukasz jest w najwyższym stopniu zainteresowany osobą Maryi i Jej rolą w dziele zbawienia, a także Jej znaczeniem dla Kościoła. Na podstawie dostępnych mu źródeł kreśli pełen ekspresji obraz Matki Chrystusa. Powtarzające się wzmianki o Maryi i ukazywanie Jej jako wzorca wiary są znakami wyjątkowej czci Łukasza dla Maryi. Jego Ewangelia to poświadczenie pierwszego kultu maryjnego w Kościele pierwotnym ${ }^{19}$.

\subsubsection{Mariologia św. Jana: Matka Jezusa}

Maryja występuje w Ewangelii św. Jana (choć jej imię nie jest tam podane) w dwóch decydujących momentach publicznej działalności Jezusa, objawiających Jego zbawczą moc: na początku działalności - na weselu w Kanie i w Jej końcowym, najważniejszym momencie - podczas Jego śmierci na krzyżu. Interpretując te perykopy, należy przypisać Maryi funkcję symboliczną w odniesieniu do Kościoła. W obu przypadkach jest Ona przedstawicielką nowej wspólnoty. Ta symbolika - jak zauważa Joachim Wanke - pozwala mówić „o uprzywilejowanej roli” Maryi w myśleniu szkoły Janowej $j^{20}$.

Odwołajmy się do pierwszej perykopy Janowej, gdzie jest wzmiankowana Maryja:

W Kanie Galilejskiej odbywało się wesele i była tam Matka Jezusa. Zaproszono na to wesele także Jezusa i Jego uczniów. A kiedy zabrakło wina, Matka Jezusa mówi do Niego: „Nie mają już wina”. Jezus Jej odpowiedział: „Czyż to moja lub

${ }^{19}$ Por. F. Courth, Mariologia. Maryja, Matka Chrystusa, dz. cyt., s. 97-99; por. S. Budzik, Maryja w tajemnicy Chrystusa i Kościoła, dz. cyt., s. 21-33.

${ }^{20}$ Por. J. Wanke, Maria im vierten Evangelium, [w:] Theologisches Jahrbuch (L), Leipzig 1983, S. 124 . 
Twoja sprawa, Niewiasto? Czyż jeszcze nie nadeszła godzina moja?”. Wtedy Matka Jego powiedziała do sług: „Zróbcie wszystko, cokolwiek wam powie”. Stało zaś tam sześć stągwi kamiennych przeznaczonych do żydowskich oczyszczeń, z których każda mogła pomieścić dwie lub trzy miary. Rzekł do nich Jezus: „Napełnijcie stągwie wodą!”. I napełnili je aż po brzegi. Potem do nich powiedział: „Zaczerpnijcie teraz i zanieście staroście weselnemu!”. Oni zaś zanieśli. A gdy starosta weselny skosztował wody, która stała się winem nie wiedział bowiem, skąd ono pochodzi, ale słudzy, którzy czerpali wodę, wiedzieli - przywołał pana młodego i powiedział do niego: „Każdy człowiek stawia najpierw dobre wino, a gdy się napiją, wówczas gorsze. Ty zachowałeś dobre wino aż do tej pory". Taki to początek znaków uczynił Jezus w Kanie Galilejskiej. Objawił swoją chwałę i uwierzyli w Niego Jego uczniowie (J 2, 1-11).

Tematem tej perykopy jest „początek znaków”, jaki uczynił Jezus podczas wesela w Kanie Galilejskiej, doprowadzając uczniów do wiary przez objawienie swojej chwały: „Objawił swoją chwałę i uwierzyli w Niego Jego uczniowie” (J 2, 11). Na dyskretną prośbę Maryi Jezus wydaje się odpowiadać odmownie: „Czyż to moja lub Twoja sprawa, Niewiasto?”. To trudne miejsce biblijne należy chyba odczytywać zarówno jako dystans, jak i nawiązanie kontaktu; z jednej strony to zakwestionowanie prośby Maryi, ale z drugiej zaproszenie do pogłębionego spojrzenia na sens mających dopiero nastąpić wydarzeń. Odpowiedź jest więc odmowna w sferze czysto ludzkiej. Jezus kieruje jednak matczyną troskę na płaszczyznę swego mesjańskiego powołania, odwołując się do mającej nadejść godziny uwielbienia ${ }^{21}$.

Maryja nie rozumie słów Jezusa jako zdecydowanej odmowy, skoro zwraca się natychmiast do służących: „Zróbcie wszystko, cokolwiek wam powie”. Medytując nad tą perykopą, św. Ambroży (ok. 339-397) zanotował:

Maryja nie zwątpiła, lecz uwierzyła i dlatego otrzymała owoc wiary. Lecz i wy jesteście błogosławieni, którzy słyszeliście i uwierzyliście. Każda bowiem dusza, która wierzy, poczyna i rodzi Słowo i uznaje Jego dzieła. Niechaj w każdej duszy będzie dusza Maryi, aby radowała się w Bogu. Co do ciała, jest tylko jedna Matka Chrystusa; jednakże co do wiary, Chrystus jest owocem wszystkich.

${ }^{21}$ Por. M. Czajkowski, Maryja (2, 1-11; 19, 25-27), [w:] Egzegeza Ewangelii św. Jana. Kluczowe teksty i tematy teologiczne, red. F. Gryglewicz, wyd. 2 popr. i rozszerz., Lublin 1992, s. 29-30. 
Prośba Maryi i Jej wytrwałość odnoszą skutek: Jezus czyni swój pierwszy cud. Ta scena dodaje nowy rys do biblijnego obrazu Maryi - Jej miłość i troska odnoszą się nie tylko do Jezusa, lecz ogarniają także w sposób szczególny ludzi. Ewangeliczne zdanie zamykające perykopę: „Następnie On, Jego Matka, bracia i uczniowie Jego udali się do Kafarnaum, gdzie pozostali kilka dni” (J 2, 12), podkreśla, że Jan relacjonuje wydarzenie mające podstawę historyczną. Jest to również wskazówka, że Jezus, zgromadziwszy wokół siebie uczniów, nie zerwał całkowicie swoich związków z rodziną ${ }^{22}$.

Drugi fragment, scena pod krzyżem, ma niezwykłe znaczenie:

Obok krzyża Jezusa stały: Matka Jego i siostra Matki Jego, Maria, żona Kleofasa, i Maria Magdalena. Kiedy więc Jezus ujrzał Matkę i stojącego obok Niej ucznia, którego miłował, rzekł do Matki: „Niewiasto, oto syn Twój”. Następnie rzekł do ucznia: „Oto Matka twoja”. I od tej godziny uczeń wziął Ją do siebie” (J 19, 25-27).

Słowa skierowane do Matki i do umiłowanego ucznia nabierają charakteru ostatniej woli umierającego Jezusa. Przyjęcie Maryi przez ucznia "do siebie” (dosłownie „do swojego", czyli „do swojego życia”, „do swojego świata") oznaczałoby przede wszystkim to, że Maryja została powierzona pieczy Jana, skoro nie było nikogo z rodziny, kto mógłby się Nią zaopiekować. $Z$ drugiej strony zauważyć trzeba, że najpierw Jan zostaje powierzony Maryi jako syn. Tym samym Maryja razem z Janem staje się przedstawicielką uczniów śmierci Pana. Oboje stanowią znak i wzorzec radykalnego naśladowania Jezusa, bez względu na miejsce i czas. Wspólnota z Jezusem musi prowadzić przez Golgotę.

Oba teksty mają wspólne elementy - jeden i drugi ukazują rolę Maryi w godzinie Jezusa. To zasadnicze pojęcie czwartej Ewangelii. Perykopy te określają ramy działalności publicznej Jezusa, w której wypełnia On swoje zbawcze posłannictwo. W obu tekstach Jezus zwraca się do Maryi: „Niewiasto". Podobnego określenia używa wobec niewiasty samarytańskiej $(\mathrm{J}$ 4, 21) i do Marii Magdaleny (J 20, 13) - i zawsze chodzi wówczas o objawienie Jego posłannictwa. Jest to więc uroczysty tytuł, podkreślający wybranie tytułowanej osoby, której Jezus się objawia. Jednocześnie może on być rozumiany jako wskazówka, że również Maryja musi iść drogą wiary i potrzebuje Jezusowego objawienia. Święty Jan ukazuje przy tym Maryję jako

${ }^{22}$ Por. T. M. Dąbek, Bóg Ojciec i Maryja wobec Jezusa według J 2, 5 i Mt 17, 5, sM 1 (1999) nr 2, s. $167-178$. 
Tę, która przez posłuszeństwo wiary zajmuje szczególne miejsce w kręgu uczniów Jezusowych. Tytuł „Niewiasto” przywołuje na myśl tę, o której mówi Księga Rodzaju ( $\mathrm{Rdz} 3,15)$, co pozwoliło komentatorom patrystycznym na rozwinięcie antytezy Ewa - Maryja ${ }^{23}$.

\subsubsection{Apokalipsa: Kościół i Maryja}

Przywołajmy teraz maryjny fragment z ostatniej księgi Nowego Testamentu. Święty Jan w Apokalipsie pisał:

Potem wielki znak się ukazał na niebie:

Niewiasta obleczona w słońce

i księżyc pod jej stopami,

a na jej głowie wieniec $\mathrm{z}$ gwiazd dwunastu.

A jest brzemienna.

I woła, cierpiąc bóle i męki rodzenia.

I inny znak się ukazał na niebie:

Oto wielki Smok barwy ognia, mający siedem głów i dziesięć rogów

- a na głowach jego siedem diademów.

I ogon jego zmiata trzecią część gwiazd nieba:

i rzucił je na ziemię.

I stanął Smok przed mającą rodzić Niewiastą,

ażeby skoro porodzi, pożreć jej Dziecię.

I porodziła Syna - Mężczyznę,

który wszystkie narody będzie pasł rózgą żelazną.

I zostało porwane jej Dziecię do Boga

i do Jego tronu.

${ }^{23}$ Raymond E. Brown tak objaśnia rozumienie zwrotu „Niewiasto”: „Tytuł niewiasta staje się jeszcze bardziej zrozumiały, gdy odnosimy go do Księgi Rodzaju. W opisie pierwszego tygodnia publicznej działalności Jezusa mamy wiele odwołań do pierwszej księgi Biblii:

a) Prolog rozpoczyna się od słów „na początku”; te same słowa są tytułem Księgi Rodzaju w Biblii hebrajskiej;

b) w Prologu - podobnie jak w opisie stworzenia świata - czytamy, że światłość rozbłysła w ciemności;

c) w chwili chrztu Duch zstąpił na Jezusa i pozostał na Nim, co jest wyraźnym echem Księgi Rodzaju: Duch Boży unosił się nad wodami $(\operatorname{Rdz} 1,2)$;

d) czas od chrztu w Jordanie do wesela w Kanie to siedem dni, po których rozpoczyna się działalność nowego Adama - to przywołuje siedem dni stworzenia świata z Księgi Rodzaju”. 
A Niewiasta zbiegła na pustynię, gdzie miejsce ma przygotowane przez Boga, aby ją tam żywiono przez tysiąc dwieście sześćdziesiąt dni.

I nastąpiła walka na niebie:

Michał i jego aniołowie mieli walczyć ze Smokiem.

I wystąpił do walki Smok i jego aniołowie, ale nie przemógł, i już się miejsce dla nich w niebie nie znalazło. I został strącony wielki Smok, Wąż starodawny, który się zwie diabeł i szatan, zwodzący całą zamieszkałą ziemię, został strącony na ziemię, a z nim strąceni zostali jego aniołowie.

I usłyszałem donośny głos mówiący w niebie: „Teraz nastało zbawienie,

i władza Jego Pomazańca, potęga i królowanie Boga naszego

bo oskarżyciel braci naszych został strącony, ten, co dniem i nocą oskarża ich przed Bogiem naszym.

A oni zwyciężyli dzięki krwi Baranka i dzięki słowu swojego świadectwa i nie umiłowali dusz swych - aż do śmierci.

Dlatego radujcie się, niebiosa i ich mieszkańcy!

Biada ziemi i biada morzu

- bo zstąpił do was diabeł, pałając wielkim gniewem, świadom, że mało ma czasu".

A kiedy ujrzał Smok, że został strącony na ziemię, począł ścigać Niewiastę, która porodziła Mężczyznę.

I dano Niewieście dwa skrzydła orła wielkiego, by na pustynię leciała na swoje miejsce, gdzie jest żywiona przez czas i czasy, i połowę czasu, z dala od Węża.

A Wąż za Niewiastą wypuścił z gardzieli wodę jak rzekę, żeby ją rzeka uniosła.

Lecz ziemia przyszła z pomocą Niewieście i otworzyła ziemia swą gardziel, 
i pochłonęła rzekę, którą Smok ze swej gardzieli wypuścił.

I rozgniewał się Smok na Niewiastę,

i odszedł rozpocząć walkę z resztą jej potomstwa,

z tymi, co strzegą przykazań Boga

i mają świadectwo Jezusa (Ap 12, 1-17).

Natchniony autor prezentuje prześladowanie Niewiasty i jej Dziecka przez smoka. Postać Niewiasty opisanej w centralnym, dwunastym rozdziale Apokalipsy odnosi się przede wszystkim do Ludu Bożego, zwłaszcza zaś do jego części wiernej Bogu, nazywanej przez proroków „Resztą Izraela”. Owa „Reszta” była przedstawiana topicznie jako Niewiasta - wierna Bogu Oblubienica, Dziewica, Córa Syjonu. Z niej właśnie miał się narodzić oczekiwany Mesjasz - Chrystus. Najczystszą postacią tej „Reszty” jest Maryja dziewicza Matka Syna Bożego.

Liczne aluzje do biblijnych tekstów maryjnych skłaniały zarówno niektórych ojców Kościoła, jak i licznych późniejszych komentatorów (między innymi Hansa Ursa von Balthasara) do podwójnej interpretacji tego tekstu: eklezjologicznej i mariologicznej. I rzeczywiście, Niewiasta opisana w Apokalipsie przybiera rysy zarówno Maryi, jak i Kościoła. Liturgia w obrazie Niewiasty, obleczonej w słońce, mającej księżyc pod stopami, widzi biblijny obraz wniebowzięcia ${ }^{24}$. W teologii katolickiej przyjmuje się obecnie właściwie trzy możliwe interpretacje, wcale się niewykluczające, że Niewiastą jest: 1. Kościół, 2. Maryja, 3. Kościół i Maryja.

\subsection{W kierunku biblijnej mariologii i maryjności}

Podobnie jak teksty biblijne Starego Testamentu są jedynie alegorią, zapowiedzią lub też figurą maryjną, z której należy wydobyć głębszy sens, tak przekaz Nowego Testamentu pozwala się zatrzymać już na literalnym znaczeniu tekstu, aby wychodząc od niego, dojść do realnego oraz teologicznego znaczenia miejsca i funkcji Maryi w historii Jezusa i dziejach Kościoła. Podsumowaniem powyższych rozważań na temat tego, jaki wkład w mariologię wniosły biblijne teksty św. Pawła Apostoła oraz czterech ewangelistów, są użyte wczesnej określenia, podkreślające aspekty obecności Maryi w Piśmie Świętym: „bezimienna rodząca”, Maryja w rodzinie

${ }^{24}$ Por. S. Budzik, Maryja w tajemnicy Chrystusa i Kościoła, dz. cyt., s. 33-37. 
eschatycznej i biologicznej, Maryja w rodowodzie Jezusa przez pryzmat Józefa, Maryja wiary, Matka Jezusa, Kościół i Maryja.

Kończąc paragraf o biblijnych podstawach teologii maryjnej, należy stwierdzić, że:

1. Pismo Święte przekazuje nam wprawdzie nieliczne wiadomości z życia Maryi, są one jednak dość bogate w treść. Wszystkie wypowiedzi biblijne na Jej temat mają charakter teologiczny, przy czym można zauważyć wzrost zainteresowania osobą Matki Chrystusa w trakcie redagowania pism Nowego Testamentu.

2. W absolutnym centrum zainteresowania Nowego Testamentu znajduje się Chrystus. Wszystkie inne postacie są podporządkowane Jego Osobie i Jego misji. Wielkość i niezwykła rola Maryi płynie z Jej szczególnej i nierozerwalnej łączności z Chrystusem.

3. Zainteresowanie biblijnych autorów rolą Maryi ma charakter eklezjologiczny. Maryja jest typem Kościoła. Na Jej przykładzie ukazane są najważniejsze cechy nowej wspólnoty założonej przez Chrystusa i postawa, jakiej wymaga On od swoich uczniów i uczennic.

4. Maryja z jednej strony jest przedstawiona jako przedmiot szczególnego wybrania Bożego, jako dziewicza Matka Chrystusa. Z drugiej - Nowy Testament uwypukla Jej osobistą postawę posłuszeństwa w wierze i służebne zatroskanie o sprawy Boga i ludzi, Jej dyskretną obecność przy narodzinach Jezusa, w Jego dzieciństwie, przy rozpoczęciu działalności publicznej, Jego krzyżowej śmierci i przy narodzinach Kościoła.

5. Świadectwo Pisma Świętego o Maryi ma charakter raczej dyskretny. Powściągliwy ton zaznacza się na wszystkich etapach rozwoju mariologii biblijnej. Mimo to autorzy Nowego Testamentu przekazali zasadnicze cechy obrazu Maryi i Jej roli w dziele zbawienia. „Szkic to bogaty, lecz nie do końca jasny. Duch Święty nie ukazał jeszcze wszystkich jego linii jak rzeźbiarz, który nie cyzeluje od razu wszystkich szczegółów postaci. Kościół będzie stopniowo poznawał pełny sens tego niejasnego szkicu"25.

Będąc cielesną Matką Jezusa i osobą związaną z historią odkupienia, Maryja w Nowym Testamencie pozostaje nieustannie postacią symboliczną. Wskazania biblijne dotyczące tej postaci nadal dają otwarte pole do pogłębionej i, jak się wydaje, nigdy niewyczerpanej interpretacji. Jest ona bezimienną rodzącą, żywym przykładem wiary, przedstawicielką uczniów i pierwszej Jezusowej wspólnoty ponownie później ukonstytuowanej przez

${ }^{25}$ R. Laurentin, Matka Pana. Traktat mariologiczny, dz. cyt., s. 45. 
Zmartwychwstałego, jest nowym Izraelem, „świętą Resztą” i Córą Syjonu. Patrystyczne określenie „wzorzec i typ Kościoła” znajduje w odniesieniu do niej jak najbardziej poprawne uzasadnienie. Maryja reprezentuje nie tylko Izrael, lecz także jeszcze wyraźniej Kościół jako wspólnotę naśladowców Jezusa i wierzących w Niego jako Mesjasza. Jest związana z Izraelem, gdyż to w Niej anioł widział spełnienie obietnicy danej kiedyś przez Izajasza całemu Izraelowi. Jest przedstawicielką Kościoła, gdyż jako pierwsza zawierzyła Bożej obietnicy oraz przyjęła, poczęła i wychowała Jezusa Chrystusa, swojego Syna i Odkupiciela - aby w Duchu Świętym patronować Kościołowi apostolskiemu, a po swoim wniebowzięciu być Wspomożycielką, Pośredniczką i Orędowniczką całego Ludu Bożego na jego eschatycznej drodze ku pełni czasów w chwalebnym Chrystusie. W tym napięciu między perspektywą personalistyczną a symboliczną znajduje się właściwe odniesienie mariologii i maryjności do chrystologii i eklezjologii. Aspekt osobowy Maryi należy odnosić do jej związków z Chrystusem, a aspekt symboliczny tej Niewiasty winien być podkreślany zawsze tam, gdzie wydobywamy Jej relację do Kościoła ${ }^{26}$.

${ }^{26}$ Por. F. Courth, Mariologia. Maryja, Matka Chrystusa, dz. cyt., s. 100-101. 


\section{Dzieje maryjnej teologii i duchowości}

Rozwój refleksji teologicznej nad miejscem i rolą Maryi w dziejach zbawienia ludzkości trwa już dwa tysiące lat. Proces ten nie przebiega równomiernie. Teologiczny punkt widzenia bywał nierzadko oddzielany od aspektu kultycznego, osiągającego nadmierną przewagę. $Z$ jednej strony bowiem pobożność maryjna jest zewnętrznym wyrazem nauki wiary, z drugiej zaś rozwój czci maryjnej w liturgii Kościoła stanowił znaczący impuls do pogłębienia nauki teologów i precyzowania prawd maryjnych przez Urząd Nauczycielski Kościoła. Działalność Magisterium widać zwłaszcza wyraźnie przy określaniu ostatnich prawd dogmatycznych, m.in. niepokalanego poczęcia, wniebowzięcia. Funkcja porządkująca i regulująca Urzędu Nauczycielskiego ujawniła się także w ostatnich latach. Pod koniec xx wieku powstał w Stanach Zjednoczonych ruch Vox Populi Mariae Mediatrici, promujący ideę nowego dogmatu maryjnego o Maryi jako Współodkupicielce, Pośredniczce i Orędowniczce. Ustosunkowując się do tych próśb, Stolica Apostolska skierowała prośbę do Międzynarodowego Kongresu Mariologicznego, obradującego w Częstochowie w 1996 roku, który zaopiniował ją krytycznie i ostatecznie Rzym zajął negatywną postawę wobec tych postulatów ${ }^{1}$.

Najszersze spojrzenie na historię teologii i czci maryjnej w Kościele pozwala dostrzec dwa główne etapy, odpowiadające w najogólniejszych zarysach pierwszemu i drugiemu tysiącleciu historii Kościoła. Cechą charakterystyczną pierwszego, zdominowanego przez teologię ojców Kościoła, jest

Por. S. C. Napiórkowski, Nauczanie papieskie. Maryja w nauczaniu Kościoła, [w:] EK, t. 12, Lublin 2008, k. 17 . 
ujmowanie roli Maryi w kontekście chrystologicznym i eklezjologicznym. Okres ten podzielić można na dwa podokresy.

Pierwszy z nich rozciąga się od czasów Nowego Testamentu aż do trzeciego soboru powszechnego w Efezie w 431 roku. Jest to czas, w którym Kościół starał się wyrazić za pomocą dostępnej mu aparatury pojęciowej zawartą w Piśmie Świętym Nowego Testamentu tajemnicę Jezusa Chrystusa. Z kolei dzieło odkupienia człowieka, dokonane w Chrystusie, kieruje uwage ojców Kościoła na ludzką naturę przyjętą przez istniejącego od wieków Bożego Syna, a następnie na Jego narodziny w czasie i ziemską działalność aż po założenie Kościoła. Zarówno przy opisywaniu tajemnicy Chrystusa, jak i przy rozważaniu dokonanego przez Niego dzieła odkupienia osoba i posłannictwo Maryi odgrywają niezwykle ważną rolę teologiczną. Dla św. Grzegorza z Nazjanzu (ok. 330-39o) nauka o Maryi jest kluczem do zrozumienia zagadnień chrystologicznych.

Drugi okres to czas od soboru efeskiego aż do początków scholastyki. W centrum zainteresowania znajduje się wówczas eklezjologiczna rola Maryi. Matka Chrystusa jest rozważana i czczona jako typ Kościoła. Święta maryjne, ikony, modlitwy i hymny są uznane za formy pogłębiania wiary w niezwykłe posłannictwo Najświętszej Maryi Panny. Liturgia i sztuka Kościoła odzwierciedlają istotne treści mariologii, choć nie są one jeszcze przedmiotem systematycznej refleksji. Kościół wschodni zatrzymuje się niejako na tym etapie. W jego liturgii i duchowości przyznaje się Matce Chrystusa znaczące miejsce, jednakże nie prowadzi to do teologicznej systematyzacji, czyli do wykształcenia się traktatu mariologicznego.

Z kolei drugie tysiąclecie rozwoju nauki o Maryi cechuje się indywidualizacją spojrzenia na Matkę Chrystusa. Początek scholastyki przynosi nowe tendencje w teologii maryjnej. Średniowieczny indywidualizm sprawia, że uwaga teologów zwraca się w kierunku szczegółowego rozpatrywania osoby Matki Bożej. Zamiłowanie myślicieli scholastycznych do systematyki wpływa na ukształtowanie się traktatu mariologicznego jako części teologii. Przedmiotem refleksji są przede wszystkim niezwykłe przywileje, jakimi Bóg obdarzył Matkę swojego Syna. Ukazujące się liczne kazania, dysputy, traktaty i sumy teologiczne; są one ilustracją hasła De Maria numquam satis („O Maryi nigdy dość).

Kulminacją tego okresu rozwoju jest tzw. stulecie maryjne, jak nazwano czas pontyfikatów kilku papieży: poczynając od Piusa Ix (pontyfikat w latach 1846-1878), a kończąc na Piusie XII (1939-1958). Ramy tej epoki wyznaczają dwa dogmaty maryjne, ogłoszone na jej początku i końcu: 
o niepokalanym poczęciu (1854) i wniebowzięciu (1950). Dwa inne zagadnienia stają się głównym tematem dyskusji i rozważań: pośrednictwo Maryi (jako Mediatrix) i Jej współudział w odkupieniu (jako Coredemptrix). Prowadzi to do rozwoju mariologii w kierunku soteriologicznym. Wielość publikacji na tematy maryjne zrodziła potrzebę znalezienia tzw. podstawowej zasady mariologii, która ogniskowałaby w sobie rozmaite aspekty nauki o Maryi i włączała ją w całość teologii.

Od czasu in soboru watykańskiego istnieje tendencja, która próbuje połączyć ze sobą wszystkie aspekty dotychczasowych badań i kierunków mariologicznych. Jednocześnie podnoszony jest postulat powrotu do źródeł i silniejszego włączenia mariologii w całość badań teologicznych przy podkreślaniu jej chrystocentrycznego charakteru. Kierunek posoborowej odnowy w mariologii wskazuje Konstytucja dogmatyczna o Kościele Lumen gentium, ukazująca rolę Maryi w kontekście manifestującego się w Kościele Chrystusowego dzieła zbawienia. Reakcją na pewne przejaskrawienia minionej epoki był zauważalny kryzys teologii maryjnej w pierwszych latach posoborowych. Pastoralnym owocem nowych punktów widzenia są wspominane już adhortacje Pawła vi Marialis cultus oraz Signum magnum. Katolicką wiedzę na temat Maryi i Jej czci uporządkowała Encyklika Jana Pawła II o błogosławionej Maryi Dziewicy w życiu pielgrzymującego Kościoła Redemptoris Mater z roku 1987, która w całości została poświęcona Najświętszej Maryi Pannie².

Autentyczna i pogłębiona duchowość katolicka nie może być niemaryjna. Świętość chrześcijańską osiąga się przez odwzorowywanie postaw Jezusa Chrystusa, a przecież Jego najdoskonalszym naśladowcą i uczennicą była Maryja. Ona w Duchu Świętym najlepiej do Niego prowadzi. Całe dwadzieścia wieków chrześcijaństwa potwierdza jednoznacznie, że cześć oddawana Maryi i Jej duchowość niezmiennie towarzyszyła Kościołowi³.

\subsection{Pisarze apostolscy i apologeci}

Pierwsze wieki chrześcijaństwa były okresem zmagań młodego Kościoła z otaczającym go światem judaistycznym, pogańskim i błędnymi próbami

\footnotetext{
2 Por. S. Budzik, Maryja w tajemnicy Chrystusa i Kościoła, dz. cyt., s. 42-45.

3 Por. M. Chmielewski, Maryjny wymiar duchowości katolickiej. Wybór czy konieczność?, SM 12 (2010) nr 1-2, s. 11-23.
} 
rozwiązań wysuwanymi przez samych chrześcijan (herezje, schizmy) o właściwe sformułowanie i obronę wiary w Jezusa Chrystusa jako prawdziwego Boga i prawdziwego człowieka. Dlatego nie należy oczekiwać, że znajdziemy w tym okresie bogatą refleksję teologiczną poświęconą Maryi.

W pismach ojców apostolskich, czyli pisarzy żyjących na przełomie I i II wieku, mamy jedynie kilka zdań o Maryi, a u apologetów - pisarzy żyjących w drugiej połowie II wieku - kilkanaście stron. Święty Cyprian, biskup Kartaginy (ok. 200-258), pozostawił po sobie nieliczne o Niej wzmianki. Najbardziej „maryjni” pisarze przednicejscy: św. Ireneusz z Lyonu (ok. 140202), Tertulian (ok. 150/160 - ok. 220/240) i Orygenes (ok. 185-254), poświęcili Jej po kilka stron. Większą liczbę tekstów znajdziemy u pisarzy ponicejskich, Euzebiusza z Cezarei (ok. 264-340) czy św. Atanazego Wielkiego (ok. 295-373). Pierwszy utwór naprawdę maryjny to apokryf Narodzenie Maryi, zwany Protoewangelia Jakuba, z przełomu in i III wieku; pierwsze homilie i pieśni maryjne powstaną dopiero w IV wieku.

W pierwszych wiekach nie było świątyń poświęconych Maryi, dlatego że jak trafnie zauważa Marek Starowieyski - nazywano je po prostu imieniem domu, w którym zbierano się na modlitwy. Nie do końca pewne wzmianki o kościołach maryjnych dotyczą początku IV wieku, natomiast przekazy potwierdzone pojawiły się po soborze efeskim z 431 roku. Nie było też świąt maryjnych. Kult męczenników rozwijał się stopniowo od połowy II wieku; gwałtowny jego rozwój nastąpił po uzyskaniu przez Kościół wolności, a więc od początku IV wieku. Był to kult męczenników lokalnych; w mieście, w którym zginęli, obchodziło się rocznice ich śmierci, ich „dzień narodzin” (dla nieba), czyli dzień męczeństwa. Kiedy jednak obchodzić święto Maryi, skoro nie wiadomo, kiedy i gdzie umarła i czy w ogóle umarła (Grecy mówili o koimesis, uśnięciu)? To pytanie pojawiło się jednak prawdopodobnie dopiero w III wie$\mathrm{ku}$, a na pewno w wieku Iv. Brak możliwości odpowiedzi na nie uniemożliwiał odpowiedź na kolejne: o sposób oddawania Jej czci. Dodajmy, że w pierwszych wiekach nie było teź świąt Jezusa, bo niedziela stanowiła jedyne święto - pamiątkę Jego zmartwychwstania i stworzenia świata. Pierwsze święta: Epifania i Boże Narodzenie, torują drogę cyklowi świąt roku kościelnego.

Nie znano też modlitw maryjnych. Tak popularne dziś Zdrowaś Maryjo rozpowszechniło się dopiero w XII wieku. Informacje mamy jedynie o modlitiwie Pod Twoja obronę, która pojawiła się w Egipcie w III wieku, o ile datacja papirusu, na którym się znajduje, jest poprawna ${ }^{4}$.

4 Por. Z. Pałubska, Pod Twoją obronę, [w:] Ek, t. 15, Lublin 2011, k. 964-965. 


\subsection{Ojcowie Kościoła o Matce Bożej}

Postać Maryi w sporach trynitarnych i chrystologicznych zaczyna odgrywać bardziej znaczącą rolę u ojców Kościoła. Już św. Ignacy Antiocheński (ok. 30 - ok. 107), podkreślając w Liście do Efezjan Bóstwo i człowieczeństwo Chrystusa, powołuje się z jednej strony na Jego preegzystencję w Bogu, a z drugiej na narodzenie z Maryi - nawiązując do tajemnicy Jej dziewictwa.

\subsubsection{Antyteza Ewa - Maryja}

Pismo Święte Nowego Testamentu stało się dla ojców Kościoła źródłem natchnienia do bardziej szczegółowych rozważań nad miejscem Maryi w dziejach zbawienia. W Liście do Rzymian ( $\mathrm{Rz} 5,12-21)$ św. Paweł rozwija antytezę Adam - Chrystus. Ojciec rodzaju ludzkiego (Adam), mający przekazywać życie, stał się sprawcą śmierci. Chrystus, umierając na krzyżu, przywrócił utracone życie. Ten kontekst biblijny stał się fundamentem szeroko rozwijanej w okresie patrystycznym antytezy: Ewa - Maryja, czyli porównania roli Ewy przy upadku Adama z rolą odegraną przez Maryję w Jezusowym dziele odkupienia.

Ojcowie Kościoła widzą podobieństwa między nimi w tym, że w obu przypadkach niewiasta - dziewica dokonuje wyboru mającego decydujące znaczenie dla zbawienia ludzkości. Przeciwieństwo obu postaw polega natomiast na tym, że Ewa kieruje się niewiarą i łamie posłuszeństwo wobec Boga, Maryja zaś zgadza się z wiarą na Boży plan. Rezultatem nieposłuszeństwa Ewy są grzech i śmierć, zaś skutkami posłuszeństwa Maryi - zbawienie i życie. Tę myśl formułuje po raz pierwszy św. Justyn (zm. ok. 165), systematycznie zaś rozwija ją św. Ireneusz z Lyonu; antyteza Ewa - Maryja jest integralną częścią jego teologii odkupienia znanej pod nazwą rekapitulacji, czyli odnowienia wszystkiego w Chrystusie. Dla Ireneusza paralela Ewa Maryja nie jest ani poetycką metaforą, ani podstawą literackich dywagacji, lecz niezbywalnym elementem soteriologii. $W$ jego ujęciu ta antyteza nie może być rozumiana jako „zepsucie”, a następnie „naprawienie” utraconego rajskiego stanu: od Maryi wszystko rozpoczyna się od nowa na wyższym poziomie wspólnoty człowieka z Bogiem. Przez Maryję w Chrystusie wszystko ulega rekapitulacji (tzw. recyrkulacji), czyli odwróceniu biegu historii ludzkości. Każdy z pierwotnych elementów zostaje zastąpiony: Chrystus zajmuje miejsce Adama, krzyż - drzewa upadku, Maryja - Ewy. Ireneusz podkreśla związek grzechu pierworodnego i zwiastowania. Z jego tekstów wynika jednoznacznie, że Maryja nie tylko jest początkiem zbawienia, nie 
tylko ma funkcję „chrystologiczną”, przez to, że stanowi „bramę wejściową” do Tego, który jest zbawieniem świata. W przeciwieństwie do nieposłuszeństwa Ewy Maryja okazała posłuszeństwo w swojej wierze i dlatego przypisuje Jej się znaczenie soteriologiczne, gdyż przyczyniła się do realizacji Bożego planu zbawienia. Dla Ireneusza Maryja to Orędowniczka (advocata), to Przyczyna zbawienia (causa salutis). Jest zatem rzeczą oczywistą, że dla biskupa Lyonu nie są najważniejsze podobieństwa między Ewą i Maryją istotne są niepodobieństwa ${ }^{5}$.

Przeciwstawienie Ewy i Maryi wyraził krótką formułą św. Hieronim ze Strydonu (ok. 331 - ok. 419/420): mors per Hevam, vita per Mariam („śmierć przez Ewę, życie przez Maryję").

W formie poetyckiej prezentował tę antytezę Efrem Syryjczyk (zm. 373), wysławiając niezrównaną godność i świętość Maryi. W swojej Pieśni o Najświętszej Pannie pisał:

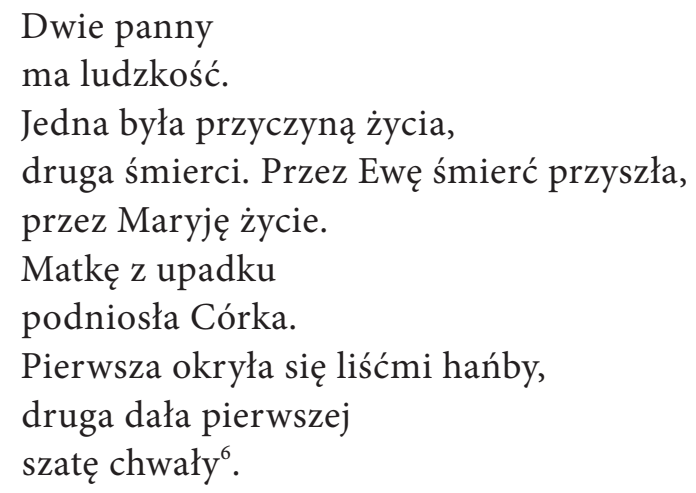

Paralela Ewa - Maryja pociąga ze sobą co najmniej dwie teologiczne konsekwencje. Najpierw ukazuje etyczne aspekty postaci Maryi i Jej funkcję historiozbawczą. Następnie Maryja jest ukazana jako przykład dla wierzących. Jest Ona wzorem ascezy chrześcijańskiej, w której akcent pada na wiarę, czystość i posłuszeństwo.

Na temat antytezy Ewa - Maryja wypowiedział się też Jan Paweł II w swoim liście apostolskim Mulieris dignitatem:

5 Por. B. Częsz, Maryja w nauczaniu św. Ireneusza z Lyonu, sm 11 (2009) nr 2, s. 70-85.

6 Por. J. Królikowski, K. Kupiec, Matka Zbawiciela. Mariologia, cz. II, Tarnów 200o, s. 4648; E. Adamiak, Traktat o Maryi, dz. cyt., s. 99-104. 
Zestawienie Ewa - Maryja powraca stale w dziejach refleksji nad otrzymanym w objawieniu Bożym depozytem wiary i jest jednym z tematów często podejmowanych przez ojców, pisarzy kościelnych i teologów. Zwykle na pierwszy plan wychodzi w tym porównaniu różnica, przeciwstawienie. Ew a jako "matka wszystkich żyjących” (por. Rdz 3, 20) jest świa dkiem biblijn ego „p o c zą t ku”, w którym zawiera się prawda o stworzeniu człowieka na obraz i podobieństwo Boga i prawda o grzechu pierworodnym. Mar yja jest świ ad kiem nowego „początku” i „nowego stworzenia” (por. 2 Kor 5, 17). Więcej, Ona sama, jako pierwsza odkupiona w dziejach zbawienia, jest „nowym stworzeniem”: jest „łaski pełna”.

\subsubsection{Aeiparthenos - zawsze Dziewica}

Najprawdopodobniej określenie Maryi jako „zawsze Dziewicy” (gr. Aeiparthenos) pojawiło się po raz pierwszy w Aleksandrii, w pismach św. Piotra z Aleksandrii (zm. 211).

Ojcowie Kościoła dokonali rozróżnienia dziewictwa Maryi przed narodzeniem (virginitas ante partum), w momencie narodzenia (virginitas in partu) oraz po narodzeniu (virginitas post partum). Początkowo między teologami zachodziły duże rozbieżności w zakresie przyjmowania poszczególnych etapów Jej dziewictwa. Pod koniec II I wieku skonkretyzowała się jednak nauka o trwałym dziewictwie Matki Bożej. Już najwcześniejsze symbole Kościoła zawierały wyznanie wiary w Jej dziewictwo, potwierdzone relacjami pierwszej i trzeciej Ewangelii o dziewiczym poczęciu Jezusa. Teraz utwierdziło się dodatkowo przekonanie, że pełne oddanie się Bogu jest stałą cechą charakterystyczną Matki Jezusa. Jej całkowite poświęcenie się Bogu objęło zarówno sferę duchową, jak i cielesną. Dziewictwo Maryi przez fakt zrodzenia Jezusa nie zostało naruszone, więcej nawet: pozostało Jej przymiotem na całe życie.

Nie obyło się tu jednak bez kontrowersji. Pełnemu dziewictwu Maryi przeczył Tertulian, przyjmując je tylko ante partum. Swoje poglądy wyraził on w dziele De carne Christi, które wyszło spod jego pióra w 206 roku. Kartagińczyk nie przyjmował dziewictwa Maryi in partu, czyli w momencie narodzin Jezusa. Wiele wątpliwości zgłaszał też Tertulian wobec dziewictwa Maryi po narodzinach Chrystusa (virginitas post patrum). Z kolei Hieronim miał w tej kwestii dość niesprecyzowany pogląd. Jan Chryzostom (350-407)

\footnotetext{
Jan Paweł II, List apostolski o godności kobiety Mulieris dignitatem, 11.
} 
dostrzegał u Maryi pewne wewnętrzne, duchowe rozterki. Pod wpływem Protoewangelii Jakuba Klemens Aleksandryjski (zm. 215) opowiadał się za dziewictwem przed zrodzeniem i w trakcie zrodzenia. W Komentarzu do Ewangelii według św. Łukasza Orygenes za prawdę wiary przyjmował jedynie dziewicze poczęcie Chrystusa ${ }^{8}$.

Nauka o trwałym dziewictwie Maryi szczególnie rozwijana była na Wschodzie. Wypada tutaj przywołać św. Atanazego, który w sporze $\mathrm{z}$ arianami głosił dziewictwo Maryi post partum, wysławiając Jej świętość i ukazując Ją jako wzór dla chrześcijańskich dziewic. Duży wkład w rozwój rozumienia maryjnego dziewictwa wnieśli ojcowie kapadoccy: Bazyli, Grzegorz z Nazjanzu oraz Grzegorz z Nyssy. Bazyli (ok. 330-379) bronił prawdy o dziewictwie Maryi przeciwko Eunomiuszowi, głoszącemu, że Maryja po zrodzeniu Jezusa miała jeszcze inne dzieci. Stąd Bazyli opowiadał się jedynie za ante partum. Podobnie jak Orygenes czy Jan Chryzostom, Bazyli, uznając moralną doskonałość Maryi, pisał też o Jej zachwianiu się w wierze w czasie męki i śmierci Jezusa na krzyżu. W utrwalenie nauki o trwałym dziewictwie Maryi zapisał się Epifaniusz z Salaminy (ok. 315-403), który swoje poglądy sprecyzował $\mathrm{w}$ sporze $\mathrm{z}$ antydikomarianitami. Twierdzili oni, że Maryja byłą najzwyczajniejszą kobietą. Po zrodzeniu Jezusa żyła w związku małżeńskim z Józefem i urodziła jeszcze inne dzieci.

$\mathrm{Na}$ Zachodzie wyróżnić należy natomiast ojca mariologii, św. Ambrożego. Wielki biskup Mediolanu rozważał dziewictwo Maryi w kontekście soteriologicznym. Zapowiadane przez proroków nowe stworzenie zostało zapoczątkowane przez nowe zrodzenie - narodziny Chrystusa z dziewiczej Matki. Podobnie i św. Augustyn (354-430) w Kościele zachodnim wypracowywał podstawy tej maryjnej prawdy wiary.

\subsubsection{Rodzicielka Boga}

Bardzo wcześnie otrzymuje Maryja tytuł Bożej Rodzicielki - Theotokos. Najstarsza, choć niepotwierdzona źródłowo tradycja, wskazuje na Hipolita Rzymskiego bądź Orygenesa (znającego to określenie) jako pierwszych teologów Bożego macierzyństwa. Trzeba tu także przywołać św. Atanazego Wielkiego, który używał tytułu Kyriotokos - Rodzicielka Pana.

Niektórzy patrologowie (np. M. Starowieyski) utrzymują, że najwcześniej tytuł „Boża Rodzicielka” chrześcijanie odnosili do Maryi w środowisku aleksandryjskim w III wieku. Wskazuje na to tekst modlitwy Pod Twoja

8 Por. M. Wysocki, Maryja w pismach Tertuliana, sM 11 (2009) nr 2, s. 109-135. 
obronę, który w formie pisemnej pojawił się prawdopodobnie w III wieku, ale $\mathrm{w}$ formie ustnej musiał funkcjonować już wcześniej. Około 285 roku w Aleksandrii znajdował się kościół dedykowany Maryi w tytule Theometer - Matka Boża. Chrześcijanie aleksandryjscy znali kulty pogańskie, a mimo to nie obawiali się używać w stosunku do Maryi tytułu mocno zakorzenionego w pogańskim (politeistycznym) środowisku.

W związku z maryjnym tytułem Mater Dei - Matka Boga powstaje pytanie o jego odniesienie do bardzo popularnych w tym otoczeniu kultów: matki boga czy matki bogów. Przykładowo można wskazać na mityczną boginię Izydę, rozpustną matkę bożka Horusa, lub na boginię Nut, czczoną jako rodzicielka bogów (rodzącą słońce i gwiazdy). Czy więc na wyobrażenie Matki Bożej Karmiącej miał wpływ kult Izydy? W basenie Morza Śródziemnego boginię Kybele (i utożsamianą z nią Artemidę czczoną w Efezie) nazywano „Wielką Matką", nie w znaczeniu matki bogów, ale bóstwa dającego życie.

Określenie „Boża Rodzicielka” miało dwie wersje: koptyjską (ludową, egipską) oraz grecką. Theotokos jest terminem technicznym. W refleksji teologicznej starano się pierwotnie unikać tego tytułu Maryi, gdyż nie chciano stawiać Matki Jezusa na jednej płaszczyźnie z boginiami Kybele, Artemidą, Astarte, Demeter, Izydą. Dlatego akcentowano bardziej to, że Maryja nie jest boginią ani boską matką jakiegoś kolejnego boga, ale konkretną postacią. Przynależy do rodzaju ludzkiego, a nie do mitologii. Jest osobą historyczną, a nie tworem wyobraźni czy projekcją intelektu. Kiedy w IV wieku pojawiła się w Arabii sekta kolyrydianek, czczących Maryję jako boginię, Kościół zdecydowanie od nich się odciął. Nazwa tego ugrupowania pochodziła od składanych Maryi w ofierze małych placuszków, nazywanych kolyrydiami. Kult ten opisał Epifaniusz z Salaminy, który w 377 roku ostro wystąpił przeciw nabożeństwom ofiarniczym ku czci Maryi, szerzonym przez kolyrydianki ${ }^{9}$.

W swoim Liście do Kościoła w Efezie Ignacy Antiocheński nauczał, że Jezus był „zrodzony z Maryi i zrodzony z Boga”" ${ }^{\text {". }}$ Z kolei Justyn (zm. 167) w Dialogu $z \dot{Z} y$ dem Tryfonem wykazywał preegzystencję Syna Bożego (odwieczne zrodzenie z Boga) oraz Jego narodzenie z Matki Dziewicy. Kilkanaście lat później w dyskusji z gnostykami Ireneusz z Lyonu utrzymywał, że Maryja jest prawdziwą Matką Jezusa. Jej macierzyństwo było rzeczywiste, a nie pozorne. Jezus otrzymał od Maryi realne, ludzkie ciało. Macierzyństwo

\footnotetext{
9 Por. J. Jezierski, Maryja początkiem nowego świata..., dz. cyt., s. 30-31.

${ }^{10}$ Ignacy Antiocheński, List do Kościoła w Efezie, 4, 2.
} 
potwierdza wydarzenie wcielenia. Grzegorz z Nyssy pisał, że uznanie Maryi za Bożą Rodzicielkę stanowi kryterium prawowierności. Mariologia stała się dla niego kluczem do zrozumienia zagadnień chrystologicznych.

Ważnym impulsem do pogłębienia chrześcijańskiej refleksji nad macierzyństwem Maryi był Sobór Efeski, zainicjowany sporami chrystologicznymi i nauką o współistotności Ojca i Syna. Zakończył on spór aleksandryjczyków, reprezentowanych przez Cyryla z Aleksandrii (378-444), z antiocheńczykami, których przedstawicielem był Nestoriusz (384-451). Odrzucając tytuł Bożej Rodzicielki, Nestoriusz opowiedział się za definiowaniem Maryi jako Rodzicielki Chrystusa (Christotokos). Ten wychowanek szkoły antiocheńskiej był przekonany, że nauka ośrodka z Antiochii o Maryi jako Theotokos jest błędna, gdyż kwestionuje odwieczne zrodzenie Logosu (Syna Bożego) przez Boga Ojca (preegzystencję). Swoje stanowisko Nestoriusz opierał na postanowieniach Soboru Nicejskiego (325), który nie użył określenia Theotokos.

Zdaniem Nestoriusza Maryja jest Bożą Rodzicielką (Theotokos), ponieważ Jej cielesny syn i przedwieczny Syn Ojca są jednym i tym samym. Maryję określono jako Theotokos z przyczyn chrystologicznych, ponieważ było to ważnym elementem odpowiedzi na pytanie, kim jest Jezus Chrystus. Odpowiedzią Kościoła na to zagadnienie, ukształtowaną w długim i trudnym procesie refleksji teologicznej, była formuła głosząca, że natury Boska i ludzka Chrystusa są zjednoczone w jednej Osobie Syna Bożego. Z faktu unii hipostatycznej, czyli najściślejszego zjednoczenia obu natur w Osobie Słowa, wynika, że Maryja, chociaż przygotowała w swoim ciele ludzką naturę Chrystusa, zrodziła jednak całego Chrystusa, będącego nierozdzielnie Bogiem i człowiekiem. Jest Ona bowiem Matką osoby Jezusa, a nie zaledwie Jego natury - winna być więc nazywana Matką Bożą i jako taka czczona. Pod koniec IV wieku tytuł ten był już powszechnie używany. Definicja Soboru Efeskiego, będąca zakończeniem sporu na ten temat, stała się impulsem do wielkiego rozkwitu pobożności maryjnej i rozwoju mariologii ${ }^{11}$.

\subsubsection{Panhagia}

Przedmiotem rozważań i sporów w pierwszych wiekach chrześcijaństwa były także świętość i bezgrzeszność Maryi. Nauka ta znajdowała przeciwników

${ }^{11}$ Por. E. Florkowski, Matka Boża w nauce Ojców Kościoła, [w:] Gratia plena..., dz. cyt., s. 75 . 
u niektórych ojców i pisarzy Kościoła, czego głównym powodem była wieloznaczność terminu „świętość” i chęć podkreślenia powszechności odkupienia dokonanego przez Chrystusa. Dlatego na Wschodzie dość wcześnie rozpowszechnił się sposób postrzegania Maryi jako najświętszej, całkowicie i absolutnie świętej (panhagia), natomiast na Zachodzie treść tych określeń pojmowano przede wszystkim w sensie zachowania od winy Adama, na co decydujący wpływ miała koncepcja grzechu pierworodnego św. Augustyna.

$\mathrm{Na}$ Wschodzie o nieskalanej czystości i świętości Maryi pisał Efrem Syryjczyk. Podobnie świętość Maryi głosił najsławniejszy przedstawiciel szkoły antiocheńskiej, Jan Chryzostom, mimo że niewiele uwagi poświęcał tej postaci. W swoich dość moralizatorskich homiliach, wytykając pewne słabości Maryi, np. próżność i szaleństwo, ten ojciec i doktor Kościoła dążył do przezwyciężenia magicznego rozumienia świętości osiąganej automatycznie. Wielu bowiem zapominało o cierpieniach Matki Chrystusa, ubóstwie, samotności, dotykających Ją obmowach.

Źródło trudności w zrozumieniu świętości Maryi znajdowało się w prawdzie, że pełnię świętości posiada tylko Chrystus, a wszyscy ludzie są grzesznikami. Aby nie stosować tych samych Chrystusowych kryteriów do Maryi, niekiedy wręcz sztucznie doszukiwano się u Niej moralnych braków i słabości. Jednak pod wpływem św. Ambrożego i św. Augustyna, jak również w konsekwencji efeskiej definicji Bożego macierzyństwa, nauka o świętości i bezgrzeszności Maryi - w znaczeniu Jej świętości moralnej i pełni cnót stała się trwałym elementem wiary Kościoła.

U schyłku IV wieku - w liście św. Epifaniusza z Salaminy do chrześcijan Arabii z 377 roku - pojawiło się pytanie o koniec ziemskiego życia Matki Bożej. Ojcowie Kościoła rozważali często tajemnicę Maryi w kontekście nauki o Kościele, przy czym punktem odniesienia stawały się Jej dziewictwo i macierzyństwo. Kościół zachowuje nienaruszoną wiarę, a przez łaskę zaślubiony jest Chrystusowi. Poprzez wiarę i sakramenty daje życie łaski coraz to nowym rzeszom swoich członków. Analogia pomiędzy Maryją a Kościołem jest przedmiotem rozważań i wypowiedzi wielu ojców, swój najpełniejszy wyraz znajduje jednak w nauce Augustyna z Hippony. W sporze Augustyna z pelagianizmem poruszony został po raz pierwszy problem niepokalanego poczęcia Maryi ${ }^{12}$.

${ }^{12}$ Por. M. Starowieyski, Maryja w Kościele starożytnym, [w:] Matka Jezusa pośród pielgrzymującego Kościoła, red. J. S. Gajek, K. Pek, Warszawa 1993, s. 89-9o (Theotokos, 4). 


\subsubsection{Cześć maryjna}

Rozbudzona pobożność maryjna znajduje w następnych wiekach silne odzwierciedlenie w liturgii Kościoła. Wypracowane w intelektualnej i duchowej refleksji tytuły maryjne znajdują szerokie zastosowanie w liturgii i pobożności, tak prywatnej, jak i wspólnotowej. Oczywiście nie wszystkie określenia są używane z jednakowym natężeniem. Tytuł „Matka” był stosowany częściej i szerzej. Występował z dookreśleniami, jak np. u Epifaniusza z Salaminy: „nasza Matka”, „Matka żyjących”.

W V, vi i viI wieku powstają i rozprzestrzeniają się pierwsze święta ku czci Maryi: święto Zaśnięcia (później Wniebowzięcia) Maryi - 15 sierpnia, Ofiarowania w świątyni (Hypapante) - 2 lutego, Zwi as tow ania - 25 marca, Narodzenia -8 września, Poczęcia -8 grudnia. Święta maryjne powstawały $\mathrm{z}$ reguły $\mathrm{w}$ kręgu syryjsko-palestyńskim, a stamtąd rozszerzały się na całe Cesarstwo Wschodniorzymske i stopniowo były przejmowane przez Kościół zachodni. Dawały okazję teologom i pisarzom kościelnym do rozwijania nauki o Maryi w licznych homiliach i mowach ${ }^{13}$.

W tym czasie powstaje szereg modlitw skierowanych wprost do Matki Bożej. Najstarszą z nich, nie licząc Ave Maria z Ewangelii św. Łukasza (pozdrowienie Gabriela połączono z pozdrowieniem Elżbiety zresztą znacznie później), jest zapisana na odkrytym w roku 1938 papirusie modlitwa Pod Twoją obronę, pochodząca, jak już wspominaliśmy, prawdopodobnie z III wieku. Nie sposób tu nie wymienić także modlitwy Akathistos, wspaniałej pieśni na cześć Matki Jezusa.

Ważnym wydarzeniem z punktu widzenia kultu maryjnego było przezwyciężenie tzw. obrazoburstwa na Drugim Soborze w Nicei w roku 787.

W rozwoju czci maryjnej i nauki o Matce Bożej wiodącą rolę odegrał więc Kościół wschodni. W licznych homiliach i rozprawach pisarzy bizantyjskich odnajdujemy wyraźne ślady wiary we wniebowzięcie Maryi, Jej niepokalane poczęcie i macierzyństwo duchowe. Syntezę mariologii patrystycznej zawdzięczamy jednemu z ostatnich ojców Kościoła wschodniego, św. Janowi Damasceńskiemu (ok. 675 - ok. 754). Kościół zachodni w drugiej połowie pierwszego tysiąclecia nie odznaczał się bogactwem maryjnej pobożności. Dopiero następna epoka przyniesie zmianę tej sytuacji, ponieważ w średniowieczu to w chrześcijaństwie zachodnim mariologia i maryjność będą przeżywały rozkwit.

${ }^{13}$ Por. S. Budzik, Maryja w tajemnicy Chrystusa i Kościoła, dz. cyt., s. 45-50. 


\subsection{Maryja w teologii średniowiecza}

W odróżnieniu od patrystyki, która naukę o Maryi rozważała przede wszystkim w kontekście centralnej tajemnicy wcielenia Syna Bożego, zainteresowanie teologii średniowiecznej, zwłaszcza w jej fazie scholastycznej, kieruje się ku roli Maryi w dziele odkupienia. Matka Chrystusa rozważana jest jako Jego Współpracownica. Dlatego rodzi się pragnienie bardziej zindywidualizowanego podejścia do Jej postaci. Teologia i pobożność średniowieczna chcą coraz więcej wiedzieć o osobie Maryi i Jej życiu. Przedmiotem zainteresowania stają się szczególne przymioty, jakie łaska Boża związała z Jej posłannictwem. Człowiek średniowiecza, tak bardzo zatroskany o zbawienie swojej duszy, zwraca się do Maryi jako Orędowniczki, Pośredniczki i Pocieszycielki. Pobożność maryjna ogarnia coraz szersze kręgi wiernych, w wyniku czego zostaje spłycona, a nauka o Maryi popada niekiedy w sztuczne dywagacje i bezpodstawne dedukcje.

Nie do końca poprawne drogi mariologii i maryjności wczesnego średniowiecza były w dużej mierze rezultatem pojawienia się znacznej ilości apokryfów czy innych pobożnych pism czy legend. Krytyczna ich ocena stała się w VIII wieku zasługą między innymi: św. Germana z Konstantynopola (ok. 634-733), św. Andrzeja z Krety (ok. 650 - ok. 740), św. Jana Damasceńskiego.

Sztuczność rozważań nad postacią Matki Jezusa przyjmowała różne formy. Zastanawiano się np. nad kolorem szat archanioła Gabriela. Pytano także o szczegóły wyglądu Maryi, jak kolor Jej włosów ${ }^{14}$, skóry i oczu. Odpowiedzią były zawiłe spekulacje teologiczne. Mnożyły się w średniowieczu zbiory relikwii maryjnych. Z zachowanych do dziś rejestrów można się dowiedzieć, że jako pamiątki po Maryi przechowywano rzekomo należące do Niej włosy, grzebień, szaty, welon, pasek, buty, a nawet fragmenty gromnicy, którą miała trzymać w godzinie śmierci ${ }^{15}$.

Ta nadmierna koncentracja na samej osobie Maryi nie do końca jednak przeszkodziła rozwojowi pogłębionej teologii maryjnej. Piotr Damiani (1007-1072) obdarzył Maryję nowym tytułem: Matka Miłosierdzia, czyli

${ }^{14}$ Włoska poetka i wizjonerka, Maria Valtorta, w Poemacie Boga-Człowieka (przeł. E. Bromboszcz, Mikołów 1996) utrzymuje, że Maryja miała „włosy jasne jak miód” (s. 29) lub „jasne” (s. 34, s. 59). Także inne wizjonerki w xx i xxI w. wykazują duże zainteresowanie wyglądem zewnętrznym Maryi.

${ }^{15}$ Por. W. Miziołek, Kult Matki Bożej, [w:] Gratia plena..., dz. cyt., s. 450. 
Chrystusa będącego Miłosierdziem. Od wieku XII datuje się wzmożone zainteresowanie rolą Maryi podczas ofiary krzyżowej Chrystusa. Teologowie dochodzili do wniosku, że trzeba zwrócić uwagę na Jej współdziałanie w Jezusowej ofierze na Golgocie, kiedy stała się Ona duchową Matką wszystkich ochrzczonych. Tematem rozważań stało się Jej współcierpienie i czynne zjednoczenie z ofiarą Syna. Mówiło się o Jej wierze w czasie triduum mortis: między dniem śmierci Chrystusa a porankiem Jego zmartwychwstania jedynie Maryja zachowała wiarę w Chrystusa, reprezentując, a nawet stanowiąc przez te dni cały Kościół. Z tego faktu wielki czciciel Maryi, Bernard z Clairvaux, jako pierwszy wyciągnie wniosek o pośrednictwie Matki Bożej, która nieustannie zanosi do Chrystusa modlitwę wstawienniczą za wszystkich członków Kościoła. Ten wpływowy teolog i kaznodzieja XII wieku, nazywany Doktorem Miodopłynnym (łac. Doctor Mellifluus), ukazuje Maryję jako Pośredniczkę wszelkiej łaski, przyrównując Ją do akweduktu łączącego nas z Chrystusem. Obok tytułu Wszechpośredniczki pojawia się także inne określenie Maryi - Szyja Kościoła (Collum Ecclesiae), które propaguje Hermann z Tournai (zm. 1137). Teologowie okresu średniowiecza piszą też o macierzyństwie duchowym Maryi. Najwięcej uwagi temu zagadnieniu poświęcają monastyczne ośrodki benedyktyńskie, cysterskie, franciszkańskie i dominikańskie. Mistrzowie życia duchowego zachęcają swoich współbraci zakonnych, aby odnosili się do Maryi jako do swej duchowej Matki, Matki miłosiernej ${ }^{16}$.

W xII wieku refleksja maryjna uzupełniana jest także żywą pobożnością. Trudno tu pominąć dynamiczny rozwój modlitwy różańcowej, propagowany przez Zakon Kaznodziejski na czele ze św. Dominikiem Guzmánem (11701221). Do szerzenia czci maryjnej przyczynili się także karmelici, a zwłaszcza bł. Szymon Stock (ok. 1175-1265) ze szkaplerzem karmelitańskim. Z kolei franciszkanie czynili wysiłki w wyjaśnianiu i rozpowszechnianiu tajemnicy niepokalanego poczęcia.

Tematem refleksji teologicznej były prawdy maryjne sformułowane mniej lub bardziej wyraźnie w epokach poprzednich, jak wniebowzięcie czy niepokalane poczęcie. To ostatnie stało się jednak przedmiotem ostrej kontrowersji, zwłaszcza pomiędzy przedstawicielami zakonu dominikanów, którzy śladem św. Tomasza z Akwinu byli przeciwnikami tej nauki, a franciszkanami, którzy za wzorem bł. Jana Dunsa Szkota byli jej obrońcami. Pierwsze

${ }^{16}$ Por. J. Warzeszak, Macierzyństwo duchowe Maryi w ujęciu teologów średniowiecznych, SM 13 (2011) nr 3-4, s. 45-64. 
pisma wyjaśniające niepokalane poczęcie wyszły spod pióra Anzelma z Canterbury. Jednakże największy wkład w wyjaśnienie i upowszechnienie tej maryjnej prawdy wniósł Jan Duns Szkot, który stwierdził, że niepokalane poczęcie Maryi bynajmniej nie przeczy powszechności odkupienia. Przeciwnie, Maryja została zachowana od grzechu, gdyż doznała odkupienia w sposób doskonalszy, a nie przez wyłączenie z powszechności odkupienia ${ }^{17}$. Obradujący w Bazylei w 1439 roku sobór opowiedział się za dogmatyzacją prawdy o niepokalanym poczęciu, jednakże ta opinia nie stała się wiążąca dla całego Kościoła. W obronie tak rozumianego kultu papież Sykstus IV (1414-1484) ogłosił bullę Grave nimis. Podobnie i Sobór Trydencki nie dokonał jednoznacznego rozstrzygnięcia w kwestii nauki o niepokalanym poczęciu Najświętszej Maryi Panny.

Warto jeszcze wspomnieć o innym elemencie średniowiecznej maryjnej doktryny i pobożności, a mianowicie przeciwstawianiu Maryi Chrystusowi. Jak Chrystus jest sprawiedliwy - tak Maryja miłosierna; jak Chrystus jest Sędzią - tak Maryja jest jedną z nas, ludzi; Chrystus jest nie tylko człowiekiem, lecz także Bogiem, którego się lękamy - Maryi nie musimy się bać, gdyż jest tylko człowiekiem. Z pewnością nie był to kierunek właściwy. Zabrakło krytycznej refleksji teologów. Najdotkliwiej ujawniło się to $\mathrm{W}$ XV wieku, kiedy ograniczono się do powtarzania tez poprzedników, a pierwszeństwo oddano nadmiernej uczuciowości i nieracjonalnej wyobraźni. Maryjne obrazy w xv wieku ukazywały Ją już nie stojącą, lecz na kolanach, a jako Matkę bolesną - w omdlewających pozach. Tkliwy sentymentalizm wyparł malarskie prezentacje Maryi, które afirmowały Jej męstwo i aktywny współudział w wydarzeniu odkupienia ${ }^{18}$.

\subsection{Reformacja: ancilla Domini}

Trudno zgodzić się z obiegową opinią, że reformacja zdecydowanie odcięła się od Maryi. Nie wolno zapominać, że pierwszymi reformatorami byli przecież katolicy, którzy podnieśli sprzeciw wobec rzymskich i hierarchicznych nadużyć, a nie wobec katolicyzmu jako takiego. Dlatego nie widzieli oni początkowo specjalnych powodów, aby dystansować się od Najświętszej

${ }^{17}$ E. Adamiak, Traktat o Maryi, dz. cyt., s. 122-125.

${ }^{18}$ Por. J. Królikowski, K. Kupiec, Matka Zbawiciela. Mariologia, dz. cyt., s. 52-57; S. Budzik, Maryja w tajemnicy Chrystusa i Kościoła, dz. cyt., s. 50-52. 
Maryi Panny. Natomiast z czasem, kiedy reformacja wypracowywała swoją własną teologię (opozycyjną wobec teologii rzymskiej), doszło do sprecyzowania i wypunktowania nadużyć szczególnie w przestrzeni kultu maryjnego. Odejście protestantyzmu od wcześniejszej mariologii było spowodowane wieloma czynnikami, między innymi przerostami średniowiecznej pobożności maryjnej; częściowo była to natomiast negatywna reakcja na rozwój teologii maryjnej w Kościele katolickim w epoce kontrreformacji.

W teologii protestanckiej od końca wieku XVI aż do wieku XIX zapanowało swoiste milczenie o Maryi. Fundamentalne prawdy maryjne, takie jak dziewicze zrodzenie Jezusa czy Boże macierzyństwo Maryi, były traktowane jako niewzruszone dziedzictwo wspólnej wiary. Dlatego protestantyzm nie neguje zasadniczej nauki o Maryi, o ile jest ona zakorzeniona chrystocentrycznie, jak np. prawda o Jej Bożym macierzyństwie. Dla ewangelików Maryja pozostaje przykładem wiary i posłuszeństwa, punktem odniesienia dla życia chrześcijańskiego w plejadzie niezliczonych świadków wiary znanych z kart Biblii i historii Kościoła. Milczenie protestanckie w kwestii nauki Maryi wyzwoliło przeciwny odruch w Kościele katolickim; po osłabieniu zainteresowania kwestią maryjną $\mathrm{w}$ drugiej połowie XVII wieku dokonało się raptowne przebudzenie. „Maryja usuwana $\mathrm{w}$ cień $\mathrm{w}$ protestantyzmie będzie systematycznie wynoszona w katolicyzmie z nieznaną dotąd siłą" ${ }^{\prime 1}$.

Za punkt wyjścia przyjmując teologię krzyża, reformatorzy przedłożyli ujęcie Maryi jako Służebnicy Pana i Uczestniczki Jego ogołocenia - Theologia crucis, którego podstawy Marcin Luter (1483-1546) umieścił w Disputatio Heildelbergae habita (1518); nie dopuszczało ono ani specjalnego miejsca dla Maryi, ani tym bardziej kultu Jej osoby. Mimo to jeszcze w roku 1518 Luter opowiadał się za nauką o niepokalanym poczęciu, a w 1522 odwoływał się nadal do wniebowzięcia. W 1521 roku opublikował słynny Komentarz do Magnificat, zwany „Ewangelią Maryi”. W późniejszych latach ojciec reformacji zaczął jednak walczyć z „fałszywym” (rzymskim) ujęciem kultu maryjnego, mając na uwadze zwłaszcza nadmierną cześć dla Maryi, która naruszała odniesienia do Chrystusa. Mimo to pozostał do końca życia zwolennikiem trwałego dziewictwa Maryi, Jej pełni łaski i bezgrzeszności. Wielokrotnie pisał, że uczy nas Ona chrześcijańskich cnót, a zwłaszcza wiary, pokory i czystości. W pewnym sensie uznawał również duchowe

${ }^{19}$ Por. R. Laurentin, Matka Pana. Krótki traktat teologii maryjnej, z fr. przeł. Z. Proczek, słowo wstępne S. C. Napiórkowski, Warszawa 1989, s. 121 (Theotokos, 1). 
macierzyństwo i orędownictwo Maryi. Równocześnie zaprzeczał zdecydowanie udziałowi Maryi w odkupieńczym dziele Chrystusa - w imię radykalnej ludzkiej niezdolności, będącej konsekwencją grzechu pierworodnego ${ }^{20}$.

Świadectwo głębokiej pobożności maryjnej pozostawił w swoich pismach szwajcarski reformator Ulrich Zwingli (1484-1531). Również Jan Kalwin (1509-1564) zachowywał podstawowe prawdy mariologii, jednakże był zdecydowanie bardziej krytyczny od pozostałych reformatorów. Stopniowo jednak, pod wpływem pryncypiów protestanckiej reformy: sola scriptura, sola gratia, sola fides, postać Maryi usuwano coraz bardziej w cień. Ostatecznie ten szwajcarski reformator zlikwidował wszystkie święta maryjne i święta apostołów. Zniósł rozróżnienie kultu na latria i dulia, zezwalając jedynie na ten pierwszy - kult oddawany Bogu. W swoich dziełach głęboko wnikał w psychologię Maryi i ukazywał Ją jako model postępowania, jak należy zachowywać Słowo Boże, oraz jako wzór drogi do Chrystusa ${ }^{21}$.

\subsection{Kultura baroku: Maryja w glorii}

Sobór Trydencki praktycznie w ogóle nie zajął się problematyką maryjną. Natomiast na płaszczyźnie teologii i pobożności negatywne stanowisko reformacji wywołało w rzymskim katolicyzmie niebywały rozwój mariologii i maryjności, zwłaszcza w krajach niedotkniętych bezpośrednio rozłamem w Hiszpanii, Portugalii, Francji, we Włoszech, na Malcie, w Polsce, w Bawarii czy Austrii. Troszczyli się o to wielcy teologowie nowego i prężnego zakonu jezuitów: Alfons Salmeron (1515-1585) i Franciszek Suárez w Hiszpanii, Piotr Kanizjusz (1521-1597) w krajach niemieckojęzycznych, Robert Bellarmin (1542-1621) we Włoszech, a w Polsce kard. Stanisław Hozjusz (1504-1579). W ich ślad poszedł Fernando Quirino de Salazar (1576-1646), publikując w 1618 roku pierwsze wszechstronne opracowanie niepokalanego poczęcia pod tytułem Pro Immaculata Deiparae Virginis Conceptione Defensio oraz traktat teologiczny o udziale Maryi w dziele odkupienia. Polski poeta tego okresu, Sebastian Grabowiecki (1540-1607), tak natomiast wysławiał Maryję:

${ }^{20}$ Por. S. De Fiores, Maria in der Geschichte von Theologie und Frömmigkeit, [w:] Handbuch der Marienkunde, Bd. I, dz. cyt., s. 166-169.

${ }^{21}$ Por. S. Budzik, Maryja w tajemnicy Chrystusa i Kościoła, dz. cyt., s. 52-55. 
Szczęśliwa Panno, i godna czci wszelkiej,

Któraś u Boga była w wadze telkiej,

Że Cię za Matkę obrał, a wnętrzności

Twe zwierzon Stwórca nieb i wszech nizkości.

Izaż jest sposób, jak dziękować mamy,

Gdy z Twej godności zbawieni się znamy?

Zaż niedołężność nasza zdoła temu,

Za żywot chwałę dać stanowi Twemu?

Przyjmijże tedy, prosiem, jakie mamy

Dzięki, jakicheś godna gdyż nie damy;

Niechaj chęć nasza Tobie wdzięczna będzie,

A przed Swym Synem lud Swój ratuj w błędzie.

Pokorne prośby puść przed święte uszy,

Racz łaskę jednać, gdy grzech cięży duszy,

Gdyż niemasz, ktoby przed sędzim ratował,

Co swe wyroki na złosne zgotował.

Syn Twój jest źródło dobroci wszelakiej,

A jeśli matkę czci syn ladajaki,

Rzecz słowo tylko, a będzie zbawiona

$\mathrm{Z}$ jego lutości dusza utrapiona.

Barokowa zasada amplificatio (powiększenia) spowodowała niebywały rozrost i szczególną płodność we wszystkich przejawach życia religijnego. Sztuka baroku skoncentrowała się na treściach religijnych o charakterze dydaktyczno-moralizatorskim, a jej ulubionym tematem była Najświętsza Maryja Panna. Drukowano liczne książki maryjne, zakładano dziesiątki maryjnych kongregacji, bractw, unii i stowarzyszeń. Pojawił się zwyczaj poświęcania całych narodów Matce Bożej. Dokonywano licznych koronacji obrazów maryjnych, rzesze pielgrzymów nawiedzały maryjne sanktuaria. Na przełomie wieków XVII i XVIII prowadziły swą działalność wybitne postacie: Jean Eudes, Ludwik Maria Grignion de Montfort i Alfons Maria Liguori. Wydane po raz pierwszy w 1750 roku przez Liguoriego dzieło Pochwała Maryi było najpoczytniejszą książką maryjną wszech czasów. Franciszek Suárez ujął mariologię w osobnej rozprawie, zamieszczając ją jako Quaestio $11 \mathrm{w}$ swojej Summa theologica. Podobnie znaczący przedstawiciel pozytywnej teologii, Dionizy Petawiusz (1583-1652), w czterech tomach swojej Theologica dogmata (Paryż 1644-1650) pisał o Matce Bożej, choć o wiele więcej miejsca zajmuje tam traktat o wcieleniu De Incarnatione. 
Wielu teologów XviI wieku, jak np. Tommaso Novati da Taggia, Guarino Guarini, Martin Philippe de Convelt, Hadrian Lyraeus, zgodnie opowiadało się za kultem Maryi w formie hyperdulia. Kult latria zastrzeżono tylko dla Boga, a do pozostałego duchowego świata (np. świętych czy błogosławionych) odniesiono kult dulia. Pojawiły się ponadto różne formy maryjnej duchowości. W tym kontekście można wymienić oblatio kongregacji maryjnych, oddanie się w niewolę Maryi, życie na kształt Maryi ${ }^{22}$.

Najbardziej dyskutowanym problemem teologicznym tego okresu było bez wątpienia niepokalane poczęcie. Niezliczona liczba publikacji, rozległe badania teologiczne i zażarte spory utorowały drogę do zdefiniowania tej prawdy w formie dogmatu przez papieża Piusa Ix.

\subsection{Oświecenie: racjonalizacja maryjnej pobożności?}

Przechodząc od xviI do xVIII stulecia, dostrzega się dość zasadniczą zmianę panoramy: pojawiają się nowa kultura, nowe wartości i modele, inna antropologia, inne sposoby zachowywania się i życia. Barokowy nadmiar zostaje poskromiony, pojawiają się pewna powściągliwość i umiar. Oświecenie ze swoim racjonalizmem wysuwa $\mathrm{z}$ jednej strony zdecydowaną krytykę przesądów i wierzeń, z drugiej zaś - hołduje paternalistycznemu despotyzmowi, który uosabiają władcy absolutni, jak np. Ludwik xIV we Francji, Maria Teresa i cesarz Józef II w Austrii, arcyksiążę Leopold II w Toskanii czy rosyjscy carowie. Wprowadzając w swoich krajach ideę "Kościoła narodowego”, owi władcy dopuszczali się znacznej instrumentalizacji Kościoła, pozbawiając go wymiaru powszechnego i równocześnie redukując jego misję jedynie do swoich doraźnych i partykularnych celów państwowych.

$\mathrm{W}$ tej atmosferze pojawiają się głosy wzywające do umiaru wobec maryjnej czci. Zarysowują się tendencje do uporządkowania nauki o Maryi. Jednocześnie ludowa pobożność maryjna rozlewa się szerokim strumieniem i przyjmuje całe bogactwo form. Wpływ krytycznej i oświeceniowej kultury paradoksalnie prowokuje do rozrostu pobożności ludowej, jak stało się w obszarze francuskim, włoskim czy niemieckojęzycznym.

\footnotetext{
${ }^{22}$ Por. S. De Fiores, Maria in der Geschichte von Theologie und Frömmigkeit, dz. cyt., s. 172-187.
} 


\subsection{XIX i XX wiek: „Uprzywilejowana”}

Europejski XIX wiek jest epoką pełną kontrastów. Wahadło czasu przemieszcza się od restauracji do rewolucji, od tradycjonalizmu do liberalizmu, od romantyzmu do oświecenia. Ten czas odznacza się ponownym ożywieniem mariologicznym i maryjnym, zwłaszcza w drugiej połowie wieku XIx, kiedy to rozpoczęło się tzw. stulecie maryjne. Jest to czas objawień maryjnych. W roku 1830 Katarzyna Labouré po objawieniu Matki Bożej przekazała światu cudowny medalik. W roku 1846 doszło do objawień maryjnych w La Salette, a w 1858 roku w Lourdes. Cztery lata wcześniej została ostatecznie zdefiniowana prawda o niepokalanym poczęciu, do której nawiązały objawienia z Lourdes („Ja jestem Niepokalane Poczęcie”). Wydarzenia te stały się potężnym impulsem dla czcicieli Maryi, nie pociągnęły jednak za sobą od razu pogłębionej refleksji teologicznej.

W wieku XIX upowszechniło się znacznie nabożeństwo do Niepokalanego Serca Maryi, które miało podkreślić przywilej Jej niepokalanego poczęcia i wszystkich skutków, które miał on dla Matki Chrystusa. Początek temu nabożeństwu dało ogłoszenie dogmatu o niepokalanym poczęciu Maryi przez papieża Piusa IX w roku 1854.

Wielu teologów powoływało się wówczas na „metodę scholastyczną”: Carlo Passaglia (1812-1887), Giovanni Perrone (1794-1876), Johann Heinrich Oswald (1817-1903), De Carolo, Jannotta. Najbardziej reprezentatywne okaże się dzieło Ludovico di Castelplanio (1830-1874), zatytułowane Maria nel Concllio delleterno ovvero la Vergine predestinata alla missione medesima con Gesù Cristo (Neapol 1872-1873, cztery tomy liczące aż 1887 stron), najsilniej oddziałująca synteza mariologii w xıx wieku. Swoją uwagę poświęcili Maryi kolejni papieże: o Matce Bożej jako Pośredniczce Wszystkich Łask mówili Leon XIII w encyklice Octobri Mense, św. Pius x w encyklice Ad diem illum i Pius XII w encyklice o powszechnym królowaniu Maryi Ad Caeli Reginam. W refleksji teologicznej Maryja była ujmowana jako U przywil e jow an a. Dopiero pod koniec wieku pojawiały się próby nowego spojrzenia na mariologię w dziełach niemieckiego teologa M. J. Scheebena oraz u angielskiego konwertyty bł. J. H. Newmana.

Początek xx wieku jest okresem znacznego ożywienia ruchu maryjnego. Rozpoczynają się regularne kongresy maryjne, które przyczyniają się do pogłębienia czci Matki Bożej. Tematem dyskusji teologicznych jest pośrednictwo Maryi (tytuł Mediatrix) i Jej współudział w dziele odkupienia (tytuł Coredemptrix). 
Okresem szczególnie owocnym dla teologii maryjnej okazał się pontyfikat papieża Piusa XII. Drogą radiową ogłosił on światu 13 października 1942 roku, w piętnastą rocznicę zakończenia objawień fatimskich, że poświęcił rodzaj ludzki Niepokalanemu Sercu Maryi. Polecił także, aby w miarę swoich możliwości uczyniły to poszczególne kraje. Pierwszy zrobił to prezydent Porugalii. W Polsce znajdującej się wówczas pod okupacją hitlerowską w obecności episkopatu Polski i około miliona pielgrzymów uczynił to prymas Polski, kard. August Hlond, 8 września 1946 roku przed obrazem Matki Bożej Częstochowskiej na Jasnej Górze. Papież Pius XII wysłał z tej okazji osobny list gratulacyjny do Polski (23 grudnia 1946 roku). Ostatecznie Ojciec Święty poświęcił ponownie w 1944 roku świat Niepokalanemu Sercu Maryi. W roku 1950, po latach wytężonych studiów i konsultacji z episkopatem światowym, uroczyście zdefiniował także dogmat wniebowzięcia. Pod auspicjami papieża powstały liczne akademie i wydziały maryjne. W roku 1954 obchodzono stulecie ogłoszenia dogmatu o niepokalanym poczęciu - Pius xı ogłosił wtedy Rok Maryjny i obwołał Maryję Królową Świata.

W historię maryjności początków xx wieku wpisały się na stałe objawienia Maryi w portugalskiej Fatimie, z których pierwsze miało miejsce 13 maja 1917 roku. Najbardziej znane jest objawienie z 13 października 1917 roku, podczas którego zdarzył się tzw. „cud słońca”. Za pontyfikatu papieża Pawła vi orędzie fatimskie usunięto w cień. Zdaniem filozofa francuskiego, Jeana Guittona ${ }^{23}$, osobistego przyjaciela Ojca Świętego, Paweł vi odnosił się z rezerwą do wszelkich objawień prywatnych. Gdy pięciuset biskupów, uczestników Soboru Watykańskiego II, prosiło go o zawierzenie Rosji Niepokalanemu Sercu Maryi, odmówił. W zamian posłał do Fatimy złotą różę.

Nowy rozdział w historii Fatimy otworzył Ojciec Święty Jan Paweł II. W rok po zamachu na jego życie na placu św. Piotra (13 maja 1981 roku) udał się do Fatimy i uroczyście zawierzył świat Niepokalanemu Sercu Maryi. Dwa lata później (25 marca 1984 roku) Jan Paweł II podczas obchodów jubileuszowego Roku Świętego na placu św. Piotra w Rzymie odnowił ten akt i ponownie zawierzył Mari świat, wszystkie narody i całą ludzkość.

Również pontyfikat Benedykta XVI (lata 2005-2013) charakteryzował się pobożnością maryjną. Cechuje ona także, choć w nieco odmienny sposób, papieża Franciszka.

${ }^{23}$ J. Guitton, Dialogi z Pawłem vi, tłum. L. Rutowska, Poznań-Warszawa 1969. 


\subsection{Sobór Watykański II: Maryja chrysto- i eklezjotypiczna}

W związku z planowanym rozpoczęciem Soboru papież Jan x XıII skierował do biskupów i uniwersytetów katolickich na całym świecie prośbę o zaproponowanie tematów, które miałyby być poruszone podczas obrad soborowych. Spośród około 2 tys. propozycji 600 domagało się wypowiedzi Soboru na temat Maryi. Połowa $\mathrm{z}$ tych głosów postulowała ogłoszenie dogmatu o pośrednictwie Matki Bożej; znaczniej mniej propozycji dotyczyło zdefiniowania dogmatu o macierzyństwie duchowym i ogłoszenia Maryi Współodkupicielką. Komisja teologiczna na podstawie tych zgłoszeń opracowała dokument, który po wielu dyskusjach i przeróbkach został uchwalony, jak już wspominaliśmy, na trzeciej sesji Soboru w roku 1964 jako rozdział virI konstytucji Lumen gentium pod tytułem Błogosławiona Maryja Dziewica, Boża Rodzicielka, w tajemnicy Chrystusa i Kościoła. Tekst konstytucji okazał się kopernikańskim przełomem w tej materii, gdyż odwrócono w nim perspektywę mówienia o Maryi: Matkę Jezusa umieszczono w Kościele, po stronie wierzących, czyli uznano ją za potrzebującą odkupienia tak jak my.

Rozdział viII soborowej Konstytucji dogmatycznej o Kościele podzielono na pięć podrozdziałów. We Wstępie (KK 52), który ukazuje łączność Maryi z Chrystusem i Kościołem, ojcowie Soboru podkreślają, że ich zamiarem nie jest przedstawienie pełnej nauki o Maryi ani też rozstrzyganie kwestii, które nie zostały jeszcze całkowicie wyjaśnione przez teologów. Celem dokumentu jest natomiast „starannie wyjaśnić zarówno rolę Błogosławionej Dziewicy w misterium Słowa Wcielonego i Ciała Mistycznego, jak i obowiązki odkupionych ludzi względem Bogarodzicy, Matki Chrystusa i Matki ludzi"24.

Fragment drugi (KK 55-59), zatytułowany Rola Błogosławionej Dziewicy w ekonomii zbawienia, rozważa rolę Maryi w ekonomii zbawienia w oparciu o teksty biblijne. Ojcowie Soboru wskazują na wypowiedzi Starego Przymierza, które ukazują Maryję jako Córę Syjonu i jako ucieleśnienie pokornych i ubogich w Izraelu, z ufnością oczekujących Bożego zbawienia. W nowotestamentalnym obrazie Maryi, w oparciu o patrystyczną antytezę Ewa - Maryja, dokument akcentuje wypowiedzi wskazujące na aktywne działanie Maryi w dziele odkupienia. Podkreślona jest szczególna łączność Maryi z Chrystusem, gdyż

${ }^{24}$ KK 54. 
była Ona obecna zarówno na początku, jak i na końcu ziemskiej działalności Jezusa i towarzyszyła tym samym narodzinom Kościoła:

Łączność Matki z Synem w dziele zbawczym uwidacznia się w chwili dziewiczego poczęcia Chrystusa i trwa aż do Jego śmierci [...]. W życiu publicznym Jezusa Jego Matka pojawia się w sposób znamienny, i to zaraz na początku, gdy na weselu w Kanie Galilejskiej, przejęta litością, spowodowała swym wstawiennictwem początek znaków Jezusa Mesjasza (por. J 2,1-11). [...] Błogosławiona Dziewica postępowała naprzód w pielgrzymce wiary i utrzymała wiernie swe zjednoczenie z Synem aż do krzyża, pod którym stanęła nie bez postanowienia Bożego (por. J 19, 25), najgłębiej współpracowała ze swym Jednorodzonym i z Jego ofiarą złączyła się matczynym duchem, z miłością godząc się na ofiarowanie zrodzonej z Niej Żertwy; a wreszcie przez tegoż Jezusa Chrystusa, umierającego na krzyżu, została oddana jako matka uczniowi tymi słowy: „Niewiasto, oto syn Twój” (por. J 19, 26-27)

Punkt trzeci (KK 60-65) pod tytułem Błogosławiona Dziewica i Kościót omawia związek Maryi z Kościołem. Związek ten ma podwójny charakter Maryja jako nasza Matka w porządku łaski stoi niejako ponad Kościołem, ale jako pierwowzór (typus) Kościoła należy - choć na pierwszym miejscu - do jego wspólnoty:

Jedyny jest nasz pośrednik według słów Apostoła: „Albowiem jeden jest Bóg, jeden też pośrednik między Bogiem a ludźmi, człowiek, Chrystus Jezus, który wydał samego siebie na okup za wszystkich” (1 Tm 2, 5n). Macierzyńska zaś rola Maryi w stosunku do ludzi żadną miarą nie przyćmiewa i nie umniejsza tego jedynego pośrednictwa Chrystusa, lecz ukazuje jego moc. Cały bowiem zbawienny wpływ Błogosławionej Dziewicy na ludzi wywodzi się nie z jakiejś konieczności rzeczowej, lecz z upodobania Bożego i wypływa z nadmiaru zasług Chrystusa, opiera się na Jego pośrednictwie, od tego pośrednictwa całkowicie zależy i z niego czerpie całą moc, nie przeszkadza zaś w żaden sposób bezpośredniej łączności wiernych z Chrystusem, ale ją umacnia ${ }^{26}$.

Tytuły Orędowniczki, Wspomożycielki, Pomocnicy i Pośredniczki, które Sobór przypisuje Maryi, mają być tak rozumiane, „że nie ujmują ani nie

\footnotetext{
${ }^{25}$ KK 57-58.

${ }^{26}$ KK 60.
} 
przydają one niczego godności i skuteczności działania Chrystusa, jedynego Pośrednika" ${ }^{27}$.

Punkt czwarty (KK 66-67) zatytułowany jest Kult Błogosławionej Dziewicy w Kościele. Niezwykłe miejsce Maryi w tajemnicy Chrystusa sprawia, że Kościół darzy Ją szczególną czcią. Ten wyjątkowy kult różni się jednak od tego, który należny jest Bogu. Kult Maryi jest relatywny - ze względu na Boga - i winien prowadzić od Matki do Syna. Ojcowie Soboru podkreślają szczególną wartość kultu liturgicznego i sprawdzonych przez wieki form pobożności, przestrzegając z jednej strony przed fałszywą przesadą, z drugiej zaś strony przed zbytnią ciasnotą umysłu. W oddawaniu czci Maryi należy uwzględnić aspekt ekumeniczny i unikać wszystkiego, co „mogłoby braci odłączonych [...] wprowadzić w błąd co do prawdziwości nauki Kościoła” ${ }^{28}$.

Dokument kończy się ukazaniem Matki Bożej jako znaku niezawodnej nadziei i pociechy dla pielgrzymującego Ludu Bożego (w części zatytułowanej Maryja znakiem niezawodnej nadziei i pociechy dla pielgrzymujacego ludu Bożego, Kk 68-69). Akcentując eschatologiczną rolę Maryi, ojcowie Soboru wyrażają nadzieję na osiągnięcie jedności i pokoju tak między Kościołami chrześcijańskimi, jak i między narodami całego świata ${ }^{29}$.

\subsection{W kierunku mariologii integralnej $\mathrm{i}$ interdyscyplinarnej}

Z perspektywy ponad pół wieku od zakończenia Vaticanum II coraz łatwiej i odpowiedzialniej można ocenić potężną zmianę dokonaną w katolickiej mariologii i maryjności. Mariologia zaprezentowana w konstytucji Lumen gentium różni się w sposób zdecydowany od maksymalistycznej i entuzjastycznej mariologii przedsoborowej, której głównym zadaniem była - jak formułuje to Stanisław Celestyn Napiórkowski - troska o „wpinanie coraz to nowych klejnotów w koronę chwały Maryi". Głównym błędem tej postaci mariologii było jej wyodrębnienie z całości nauki chrześcijańskiej. Stawała się ona „światem zamkniętym w sobie i dla siebie, wyizolowanym z szerszego

\footnotetext{
27 KK 62.

${ }^{28}$ KK 67.

${ }^{29}$ Por. S. Budzik, Maryja w tajemnicy Chrystusa i Kościoła, dz. cyt., s. 55-59.
} 
kontekstu reszty teologii, samotną wyspą czy luźno dryfującą tratwą, która potargała więzy z macierzystym statkiem czy portem teologii" ${ }^{30}$.

Konstytucja o Kościele otwiera nową drogę rozwoju chrześcijańskiej refleksji nad rolą Najświętszej Maryi Panny w dziejach zbawienia. Mariologia posoborowa zrywa z nadużywaną dotąd zasadą stosowności: decuit, potuit, ergo fecit („było stosowne, Bóg mógł to uczynić, więc uczynił”) ${ }^{31}$. Nie koncentruje się - jak to nieraz w przeszłości bywało - tylko na nauczaniu papieskim i wypowiedziach maryjnych orędowników. Próbuje natomiast wykorzystywać wszystkie źródła teologiczne, czyli Pismo Święte, Tradycję, wypowiedzi ojców Kościoła, nauczanie Soborów i Synodów, praktykę liturgiczną, doświadczenia ludzi wierzących i wspólnot chrześcijańskich, nowe miejsca teologiczne i nowe koncepcje. Pozwala to rozwijać mariologię posoborową w perspektywie biblijno-historiozbawczej i ukazywać Maryję w kontekście chrystologicznym i eklezjologicznym, a także wypracowywać mariologię integralną. Podsumowując, należy zaakcentować integralność mariologii, jej organiczne i całościowe nauczanie oraz wkomponowywanie doktryny $\mathrm{w}$ formację mariologiczną, łączącą studium, kult i życie.

Wypracowywanie nowej mariologii musi być opisywane jako pewien proces. Należy tu mówić nie tylko o integralności, lecz także o interdyscyplinarności. Nowa mariologia ma charakter długofalowy, wpisuje się w nią coraz mocniej wymiar ekumeniczny, a nawet dialog międzyreligijny. Nie sposób dziś odpowiedzialnie uprawiać mariologii, nie uwzględniając dość licznych i ważnych dokumentów różnych chrześcijańskich wyznań. Są one owocami ekumenicznego zbliżenia nie tylko między katolikami i protestantami, lecz także prawosławnych z protestantami oraz między innymi chrześcijańskimi wyznaniami.

We współczesnym protestantyzmie widać pewne odrodzenie zainteresowania Maryją. Pojawiają się głosy, że temat czci maryjnej należałoby odnieść do nadrzędnej tradycji kultu świętych Pańskich. Dietrich Ritschl, teolog reformowany, z dużym taktem pyta: dlaczego ewangelicy mieliby dyskutować o kulcie maryjnym i mariologii, które w ich oczach są zagadnieniami pozbawionymi wagi i znaczenia? - po czym na to skrajne protestanckie stanowisko sam odpowiada hipotetycznie:

${ }^{30}$ S. C. Napiórkowski, Matka naszego Pana (problemy - poszukiwania - perspektywy), Tarnów 1992, s. 15.

${ }^{31}$ Por. Z. J. Kraszewski, Mariologia, Paris 1964, s. 27. 
Ależ mogłoby przecież być i tak, że jakiś temat niesłusznie jest dla mnie czymś nieważnym. Wejście w sam dialog nie jest zaś najpierw niczym innym, jak aktem miłości: miłości do współchrześcijan i wyrazem Credo w jedność Kościoła Chrystusowego. Rzeczą ważną stać się może dla mnie to, co miłe jest w oczach drugiego, ponieważ ów drugi jest dla mnie osobą drogą $a^{32}$.

Trudno przywoływać głosy wszystkich teologów protestanckich w kwestiach mariologii i maryjności, gdyż są dość zróżnicowane. Warto natomiast odwołać się do deklaracji grupy roboczej Catolica działającej w ramach Zjednoczonego Ewangelicko-Luterańskiego Kościoła Niemiec (velKD), zatytułowanej Maryja - ewangelickie zapytania i punkty widzenia. Zaproszenie do dialogu, przedłożonego przez katolików i protestantów jako podstawa do wspólnej refleksji ${ }^{33}$. Jeszcze bardziej interesujący i pogłębiony wydaje się dokument Grupy z Dombes Maryja w Bożym planie i w komunii świętych ${ }^{34}$.

Postulowana przez Sobór oraz kościelne dokumenty ostatnich lat odnowiona teologia maryjna winna być głęboko biblijna, osadzona w tradycji, zaprzyjaźniona z liturgią, ekumenicznie otwarta na wartości innych Kościołów, uważnie i życzliwie wsłuchana w krytykę płynącą z ich strony, czytająca znaki czasu oraz odkrywająca trudy i znoje ponowoczesnego człowieka, szukającego transcendencji. Dlatego ta mariologia powinna wyraźniej uwzględniać aktualny stan antropologii oraz mocno zakorzeniać się w chrystologii i eklezjologii ${ }^{35}$. Posoborowa mariologia zamierza zatem być nie tylko integralna oraz ekumenicznie wrażliwa, lecz także interdyscyplinarna. Co to oznacza? Jej interdyscyplinarność należy ujmować dwukierunkowo, jako: 1. obecność w mariologii innych traktatów, zwłaszcza teologii dogmatycznej, i równocześnie 2. obecność mariologii w innych traktatach, zwłaszcza tych z zakresu dogmatyki. Profesor Bogdan Ferdek trafnie określa interdyscyplinarność jako łączenie mariologii z chrystologią, eklezjologią, antropologią i pneumatologią.

Gdy chodzi o chrystologię, to list Kongregacji Wychowania Katolickiego z 25 marca 1988 roku zatytułowany Maryja Dziewica w formacji

${ }^{32}$ Por. D. Ritschl, Überlegungen zur gegenwärtigen Diskussion über Mariologie, „Ökumenische Rundschau" 31 (1982) nr 4, s. 446.

${ }^{33}$ Por. A. Skowronek, Zagadnienia maryjne w dialogu ekumenicznym, [w:] Matka Jezusa pośród pielgrzymującego Kościoła, dz. cyt., s. 370-374.

${ }^{34}$ Por. A. A. Napiórkowski, Pośrednictwo Maryi w maryjnym dokumencie Grupy z Dombes, SM 4 (2002) nr 3 (15), s. 217-231.

${ }_{35}$ Por. S. C. Napiórkowski, Matka naszego Pana..., dz. cyt., s. 15. 
intelektualnej i duchowej adresowany do rektorów Seminariów Diecezjalnych i przewodniczących Wydziałów Teologicznych konstatuje:

Im głębiej Kościół wnika w tajemnicę Chrystusa, tym bardziej rozumie szczególną godność Matki Pana i Jej rolę w dziejach zbawienia. Ale w pewnej mierze prawdziwe jest również odwrotne stwierdzenie: poprzez Maryję, wyjątkowego świadka tajemnicy Chrystusa, Kościół zgłębia tajemnicę ogołocenia (kenosis) „Syna Bożego" (Łk 3, 38)

Odnośnie do eklezjologii czytamy: „W miarę jak zgłębiamy tajemnicę Kościoła, jaśniejsza się staje dla nas tajemnica Maryi. Z kolei Kościół, podziwiając Maryję, rozpoznaje swoje początki, swoją najgłębszą naturę, swoje przeznaczenie do chwały”37. Z kolei odnośnie do antropologii: „W szystko w Maryi może być odniesione do człowieka w każdym miejscu i czasie. Maryja Dziewica jest wielkim symbolem człowieka, który osiąga spełnienie najgłębszych aspiracji swojej inteligencji, woli i serca, otwierając się przez Chrystusa i w Duchu Świętym na transcendencję Boga" ${ }^{\text {"38 }}$.

Tę dwukierunkowość w interdyscyplinarnej mariologii wyznaczają ponadto wskazania listu Międzynarodowej Papieskiej Akademii Maryjnej, według którego mariologia jest „miejscem spotkania traktatów teologicznych, przestrzenią syntezy” 39 , dlatego „w różnych traktatach teologicznych powinno znaleźć się należne miejsce dla tej części, którą Matka Pana zajmowała w tajemnicy będącej przedmiotem studiów; tak na przykład wydaje się nieprawidłowym pisanie traktatów z eklezjologii, które nie poświęcają żadnej strony Świętej Maryi, to jest Tej, z której Kościół przyjmuje swój "profil maryjny»" ". Mariologia jest więc równocześnie skrzyżowaniem różnych działów teologii, z których najważniejsza jest teologia dogmatyczna, i ich koniecznym komponentem ${ }^{41}$.

\footnotetext{
${ }^{36}$ Kongregacja Wychowania Katolickiego, List Maryja Dziewica $w$ formacji intelektualnej $i$ duchowej adresowany do rektorów Seminariów Diecezjalnych i przewodniczących Wydziałów Teologicznych, 19.

${ }^{37}$ Tamże, 20.

${ }^{38}$ Tamże, 21.

39 Tamże, 20.

40 Tamże, 22.

${ }^{41}$ Papieska Międzynarodowa Akademia Maryjna, Matka Pana. Pamięć - obecność - nadzieja. Niektóre aktualne zagadnienia dotyczące postaci i misji Najświętszej Dziewicy Maryi, SM 5 (2003) nr 3, s. 327.
} 
Zauważalny w latach posoborowego kryzysu zastój w mariologii ustąpił obecnie miejsca pogłębionej refleksji nad miejscem i funkcją Maryi w tajemnicy Chrystusa i Kościoła. Zwyciężyło przekonanie, że nie można rezygnować z mariologii bez szkody dla całego systemu teologicznego. Przedmiotem rozważań stały się: miejsce mariologii pośród innych dyscyplin teologicznych, udział Maryi w dziele odkupienia, duchowe macierzyństwo, relacja Maryi i Ducha Świętego, przede wszystkim zaś temat Maryja - Kościół. Także współczesny dialog ekumeniczny wykazuje zainteresowanie rolą Maryi w Bożej ekonomii zbawienia.

W kontekście mariologicznym rozważane jest także miejsce kobiety w Kościele, co czyni między innymi papież Jan Paweł II w opublikowanym w 1988 roku liście apostolskim o godności kobiety Mulieris dignitatem. Czytamy w nim:

Za naszych czasów sprawa „praw kobiety” nabrała nowego znaczenia w szerokim kontekście praw osoby ludzkiej. Naświetlając ten stale deklarowany i na różne sposoby przypominany program, orędzie biblijne i ewangeliczne strzeże prawdy o „jedności dwojga”, czyli o tej godności i o tym powołaniu, jakie wynikają ze swoistej odmienności i „oryginalności” osobowej mężczyzny i kobiety. Dlatego też słuszny sprzeciw kobiecy wobec tego, co wyrażają biblijne słowa „on będzie panował nad tobą” ( $(\mathrm{dz} 3,16)$, nie może prowadzić pod żadnym warunkiem do „maskulinizacji” kobiet. W imię wyzwolenia się od "panowania” mężczyzny kobieta nie może dążyć do tego, by - wbrew swojej kobiecej „oryginalności” - przyswajać sobie męskie atrybuty. Zachodzi uzasadniona obawa, że na tej drodze kobieta nie „spełni siebie”, może natomiast zatracić i wypaczyć to, co stanowi o jej istotnym bogactwie. A jest to bogactwo ogromne. Okrzyk pierwszego mężczyzny w biblijnym opisie na widok stworzonej kobiety jest okrzykiem podziwu i zachwytu, który przechodzi w całe dzieje człowieka na ziemi. Osobowe zasoby kobiecości na pewno nie są mniejsze od zasobów męskości - są tylko inne ${ }^{42}$.

Jednakże najbardziej znaczącym papieskim dokumentem doby posoborowej jest z pewnością wspominana już encyklika Redemptoris Mater (1987). Znajduje się w niej wiele cytatów i odwołań do soborowego nauczania. Nie bez przyczyny encyklika św. Jana Pawła II została nazwana syntezą

\footnotetext{
${ }^{42}$ Jan Paweł II, List apostolski o godności kobiety Mulieris dignitatem, 10.
} 
ósmego rozdziału konstytucji Lumen gentium. W dokumencie papieża z Polski odnajdziemy jednak bez trudu także jego własne oryginalne akcenty.

Encyklika składa się z trzech części zatytułowanych: Maryja w tajemnicy Chrystusa, Maryja w tajemnicy Kościoła oraz Jej pośrednictwo. Święty Jan Paweł ir koncentruje uwagę czytelnika na dwóch głównych wątkach: pielgrzymce wiary Maryi oraz Jej pośrednictwie, które jest rozumiane jako macierzyństwo ${ }^{43}$.

Problematyka mariologiczna obecna jest we wszystkich współczesnych nurtach teologicznych. Aby to zilustrować, przywołajmy dwa przykłady. Południowoamerykańska teologia wyzwolenia akcentuje przede wszystkim społeczno-etyczny wymiar mariologii i kultu maryjnego. Maryja jest w niej uosobieniem ludzi znajdujących się w trudnej sytuacji społecznej, wyzyskiwanych, prześladowanych i poniżanych. Jest solidarna z tymi, którzy cierpią z powodu niesprawiedliwych układów społecznych, są zdegradowani ekonomicznie i politycznie. Szczególną rolę odgrywa w tym kontekście interpretacja Magnificat jako manifestu uciśnionych, ufających, że Bóg „strąci władców z tronu, a wywyższy pokornych”, że „nasyci głodnych”, a „bogaczy puści z niczym". Szczególną rolę odgrywa refleksja mariologiczna w nurtach teologii feministycznej - jak próbowaliśmy to pokazać już na początku książki, ukazując kontekst współczesny. Ta forma teologii wyrasta z walki o emancypację i równouprawnienie kobiet. Poddaje gwałtownej krytyce skostniałe struktury społeczne, dla których nie znajduje uzasadnienia w chrześcijaństwie. W podejściu tej teologii do tradycji związanej z Maryją z Nazaretu dostrzec można pewną ambiwalencję. Z jednej strony mamy do czynienia z gwałtownym nieraz odrzucaniem tradycyjnego obrazu Maryi jako pokornej Służebnicy Pańskiej, cichej, uległej i posłusznej. Z drugiej zaś istnieje tendencja do ukazywania Maryi jako wzoru kobiety współczesnej, wyzwolonej z patriarchalnych struktur, partnerskiej i zaangażowanej. Jej dziewicze macierzyństwo interpretowane jest jak wyraz autonomii i niezależności kobiety ${ }^{44}$.

${ }^{43}$ W osobistej pobożności Jana Pawła widać wyraźny wątek duchowego macierzyństwa Matki Jezusa; por. A. Dobrzyński, Matka w wierze: duchowe macierzyństwo Maryi w nauczaniu bt. Jana Pawła II, sM 13 (2011) nr 3-4, s. 200-238.

${ }^{44}$ Por. S. Budzik, Maryja w tajemnicy Chrystusa i Kościoła, dz. cyt., s. 6o-62. 


\section{Maryjne prawdy}

W tym rozdziale podejmiemy się prezentacji najważniejszych prawd wiary Kościoła katolickiego o Najświętszej Maryi Pannie, poczynając od głównych dogmatów. Mamy cztery zasadnicze dogmaty maryjne (macierzyństwo, dziewictwo, niepokalane poczęcie, wniebowzięcie). Prawda o bezgrzeszności i świętości Maryi, mimo że nie została oficjalnie zdefiniowana i uroczyście ogłoszona - jak było w przypadku czterech powyższych - należy do całości katolickiej doktryny mariologicznej.

We współczesnym języku kościelnym i teologicznym przez dogmat rozumie się zdanie, które Kościół za pośrednictwem Urzędu Nauczycielskiego wyraźnie ogłasza jako objawione przez Boga. Definicje dogmatyczne Kościoła obowiązują wierzącego w sumieniu do ich przyjęcia, uznania i wprowadzania w życie. Należy jednak pamiętać, że istotne jest nie tyle pojęciowe ujęcie, ile rzeczywistość, na którą ono wskazuje. Ponieważ rzeczywistość nadprzyrodzona przerasta możliwości ludzkiego myślenia i języka, to definicja dogmatyczna nie wyczerpuje w pełni tajemnicy, którą opisuje. Zasady lingwistyczne, w jakich wypowiadany jest dogmat, ulegają zmianie. Każdy kolejny wiek wraz z rozwojem cywilizacji i kultury przyjmuje inne sposoby artykułowania rzeczywistości objawionej. Dokonuje się zmiana, lecz nie prawdy objawionej, tylko jej historycznej interpretacji. Mamy do czynienia z tzw. rozwojem rozumienia objawienia: coraz głębszego wnikania w nie i coraz bardziej precyzyjnego ich formułowania. Oto jedna z przyczyn tego, że niektóre dogmaty maryjne zostały sformułowane relatywnie późno.

Oprócz definicji dogmatycznych istnieją inne możliwości wypowiadania i interpretacji objawienia Bożego, jak np. liturgia, teologia, katecheza, 
homilia, hymn, modlitwa, pieśń, poezja czy sztuka sakralna i kultura chrześcijańska.

Najważniejsze wypowiedzi (dogmatyczne) Kościoła na temat Maryi są następujące:

- Maryja jest Matką Bożą: dogmat o Bożym macierzyństwie.

- Maryja pozostała zawsze Dziewicą: dogmat o trwałym dziewictwie.

- Maryja nie popełniła żadnego grzechu: dogmat o świętości i bezgrzeszności.

- Maryja jest poczęta bez zmazy pierworodnej: dogmat o niepokalanym poczęciu.

- Maryja została z ciałem i duszą wzięta do nieba: dogmat o wniebowzięciu.

Oprócz głównych dogmatów maryjnych w tym rozdziale omówimy również inne elementy nauczania Kościoła o Maryi. Zaprezentujemy jedność Najświętszej Maryi Panny z Duchem Świętym, Jej udział w dziele odkupienia, Jej pośrednictwo, macierzyństwo duchowe i relację między Maryją a Kościołem, kult Maryi, święte obrazy i ekumeniczne implikacje ${ }^{1}$.

\subsection{Matka Boga}

Cała teologia maryjna i wszelka cześć maryjna opierają się na podstawowym fakcie historiozbawczym, że Maryja jest Matką Bożą. Bez tego faktu nie miałyby większego znaczenia ani Jej cechy charakteru, ani Jej słowa i czyny. Znaczenie Maryi dla Kościoła nie byłoby większe niż w wypadku innych świętych, którzy doznają czci we wspólnocie wierzących. „Tajemnica macierzyństwa Bożego Maryi stanowi w pełnym tego słowa znaczeniu tajemnicę Jej życia. Może ona nam dać - by tak powiedzieć - Boskie zrozumienie wszystkich pozostałych tajemnic, które Jej dotyczą, i tym samym wyjaśnić je, nadając im właściwe znaczenie" ${ }^{\text {. }} \mathrm{Z}$ tych względów rozważanie podstawowych prawd maryjnych rozpoczynamy od omówienia głównego i pociągającego za sobą największe konsekwencje maryjnego dogmatu, a mianowicie Bożego macierzyństwa.

Por. S. Budzik, Maryja w tajemnicy Chrystusa i Kościoła, dz. cyt., s. 63-64.

2 L. Melotti, Maryja i jej misja macierzyńska. Zarys teologii maryjnej, przeł. T. Siudy, Kraków 1983, s. 22. 


\subsubsection{Rozwój rozumienia macierzyństwa Bożego}

Pismo Święte Nowego Testamentu wielokrotnie potwierdza bez najmniejszej wątpliwości, że Maryja jest Matką Jezusa Chrystusa. Ale tytuły „Boża Rodzicielka” czy „Matka Boga”, które nie występują wprost w Ewangelii, dla ludzi wychowanych czy to w judaizmie, czy w filozofii greckiej lub też w politeistycznej cywilizacji rzymskiej były nazbyt trudne do przyjęcia. Jak Bóg, który jest wieczny, niezniszczalny i niepodlegający zmianom, może się narodzić i mieć ziemską, biologiczną matkę? Czy mówienie o Bożej Rodzicielce nie jest reliktem babilońskich albo egipskich wierzeń pogańskich, niegodnych chrześcijanina? Czy nie czynią one Maryi boginią? Czy tytuł „Matka Boża” nie jest skandalicznym nadużyciem językowym?

W tym kontekście łatwiej będzie zrozumieć, dlaczego grecki tytuł Theotokos, używany w pierwszych wiekach chrześcijaństwa na określenie Maryi, stał się przedmiotem ostrej kontrowersji już na samym początku III Soboru Ekumenicznego w Efezie. Był to spór chrystologiczny, gdyż chodziło o wyjaśnienie sposobu połączenia natury ludzkiej i natury Boskiej w Jezusie Chrystusie. Konflikt o tytuł Bożej Rodzicielki był szczególnym wyrazem tego problemu. Stąd zostały zaproponowane określenia Najświętszej Maryi Panny jako jedynie Matki człowieka-Jezusa (Anthropotokos) lub jako Matki Chrystusa (Christotokos). Zwołany do Efezu na rok 431 Sobór przyjął ostatecznie punkt widzenia Cyryla z Aleksandrii, czyli tytuł Theotokos. Nestoriusz nie przyjmował zasady communicatio idiomatum, czyli możliwości przypisywania właściwości jednej i drugiej natury (Boskiej i ludzkiej) osobie Jezusa Chrystusa (np. orzekania, że Bóg umarł na krzyżu). To pojęcie było wyjątkowo chętnie używane w sporach ponestoriańskich, a wyjaśnione szczegółowo przez papieża Leona Wielkiego (ok. 390-461). Stanowisko syryjskiego mnicha zostało ostatecznie potępione, a on sam - wyłączony ze społeczności Kościoła. Ogłoszono dogmat o unii hipostatycznej w Chrystusie, czyli zjednoczeniu natury Boskiej i ludzkiej w Osobie Słowa Bożego. Do akt Soboru Efeskiego włączono dwanaście anatematyzmów, uchwalanych na synodzie w Aleksandrii i wyszczególniających błędy Nestoriusza. Pierwszy z nich brzmi: „Jeśli ktoś nie wyznaje, że Emmanuel jest prawdziwie Bogiem i dlatego święta Dziewica jest Matką Bożą, zrodziła bowiem według ciała Słowo Boże, które stało się ciałem - niech będzie wyłączony ze społeczności wiernych"3.

\footnotetext{
BF VI, 4 .
} 
W Efezie wierni z niezwykłym entuzjazmem przyjęli postanowienie ojców Soboru. Papież Sykstus III (432-440) na pamiątkę Soboru Efeskiego kazał umieścić mozaiki maryjne na łuku tryumfalnym nowo wybudowanej bazyliki Santa Maria Maggiore (istnieją one do dziś). Polemika teologiczna wokół terminu Theotokos nie była jednak całkowicie precyzyjna. Nawet $\mathrm{w}$ wypowiedziach św. Cyryla Jerozolimskiego (315-386) słowo hypostasis raz oznacza osobę (prosopon), a raz naturę (physis). Prowadziło to niektórych myślicieli chrześcijańskiego Wschodu do przekonania, że po zjednoczeniu pozostaje w Chrystusie tylko jedna natura. Dało to podstawę do wyodrębnienia się grupy monofizytów. Dlatego już po dwudziestu latach trzeba było zwołać następny sobór, który obradował w roku 451 w Chalcedonie (w pobliżu Konstantynopola). Sobór Chalcedoński potwierdził tytuł Theotokos w odniesieniu do Maryi. Naukę tę powtarzały liczne Sobory i Synody. Obok tytułu Bożej Rodzicielki, Dei Genitrix, pojawiał się także tytuł Mater Dei, zwłaszcza w hymnach maryjnych (w vi wieku) i na ikonach (od viII wieku).

\subsubsection{Matka Boga-Człowieka}

Wiara w Boże macierzyństwo Maryi dotyka tajemnicy zetknięcia się ograniczonego stworzenia z nieograniczonym Stwórcą. Nic więc dziwnego, że nie może być do końca wyjaśniona i we wszystkich szczegółach rozszyfrowana. Nie zwalnia to jednak człowieka od próby zrozumienia i wyrażenia prawdy o wcieleniu w myśl zasady fides quaerens intellectum - wiary poszukującej zrozumienia. W Katechizmie Kościoła katolickiego czytamy:

Jedyne i całkowicie wyjątkowe wydarzenie Wcielenia Syna Bożego nie oznacza, że Jezus Chrystus jest częściowo Bogiem i częściowo człowiekiem, ani że jest ono wynikiem niejasnego pomieszania tego, co Boskie, i tego, co ludzkie. Syn Boży stał się prawdziwie człowiekiem, pozostając prawdziwie Bogiem. Jezus Chrystus jest prawdziwym Bogiem i prawdziwym człowiekiem. Kościół musiał bronić tej prawdy wiary i wyjaśniać ją w pierwszych wiekach, odpowiadając na herezje, które ją fałszowały ${ }^{4}$.

Głębsza refleksja teologiczna nad znaczeniem dogmatu o Bożym macierzyństwie Maryi, zakotwiczonym w misterium wcielenia, musi wychodzić od odpowiedzi na pytanie, co to właściwie znaczy, że „Bóg stał się człowiekiem". Najważniejsza wypowiedź antropologiczna Pisma Świętego

\footnotetext{
${ }^{4}$ Katechizm Kościoła katolickiego [dalej: Kкк], Poznań 1994, 464.
} 
głosi, że „Bóg stworzył człowieka na swój obraz i podobieństwo” (por. $\mathrm{Rdz}$ 1, 26. 27). Z wypowiedzi tej wynika, że celem stworzenia jest trwała wspólnota człowieka z Bogiem. Dlatego Bóg jest otwarty na człowieka. Ale również człowiek - mimo swej skończoności i ze względu na brak samowystarczalności - otwarty jest na nieskończoność. W Starym Testamencie uwidacznia się to zwłaszcza w kategorii przymierza.

"Człowiek przerasta nieskończenie człowieka” - jak powiedział Blaise Pascal. Dlatego Bóg jest istotnym elementem definicji człowieka. W swojej wolności człowiek naturalnie może zanegować Boga, ale skazuje się tym samym na okaleczenie własnego człowieczeństwa. Im bardziej człowiek realizuje w swoim życiu wspólnotę z Bogiem, tym jest ono pełniejsze. W osobie Jezusa ukazała się w sposób doskonały zarówno „skłonność” Boga ku człowiekowi, jak i otwarcie się ludzkiej natury na Boga - Chrystus jako Bóg i Człowiek pełniej wyjaśnia zatem istotę człowieczeństwa. Intensywność łączności z Nim jest miarą wielkości człowieka. Trafnie wyraził to św. Jan Paweł II w swojej encyklice Redemptor hominis:

Człowiek, który chce zrozumieć siebie do końca - nie wedle jakichś tylko doraźnych, częściowych, czasem powierzchownych, a nawet pozornych kryteriów i miar swojej własnej istoty - musi ze swoim niepokojem, niepewnością, a także słabością i grzesznością, ze swoim życiem i śmiercią, przybliżyć się do Chrystusa. Musi niejako w Niego wejść z sobą samym, musi sobie „przyswoić”, zasymilować całą rzeczywistość Wcielenia i Odkupienia, aby siebie odnaleźć. Jeśli dokona się w człowieku ów dogłębny proces, wówczas owocuje on nie tylko uwielbieniem Boga, ale także głębokim zdumieniem nad sobą samym5.

W tym kontekście należy rozpatrywać dogmat o Bożym macierzyństwie Maryi, będący, jak już wspominaliśmy, bezpośrednim wnioskiem płynącym z podstawowej prawdy chrystologicznej. Jeżeli Jezus-Człowiek od pierwszego momentu swojego ziemskiego istnienia, czyli od chwili poczęcia, złączony jest w osobowej jedności ze Słowem Bożym, to jest zawsze również Bogiem. Z tego wynika, że Maryja, która wydała Go na świat, jest Matką Bożą. Macierzyństwo jest bowiem relacją odnoszącą się do osoby, a nie do natury. Każda matka jest matką nie tylko ciała swojego dziecka, lecz także całej jego osoby, mimo że - jak wyznaje Kościół - Bóg stwarza bezpośrednio duszę człowieka. Nie wolno redukować macierzyństwa ludzkiego tylko do daru

\footnotetext{
5 Jan Paweł II, Encyklika Redemptor hominis, 10.
} 
życia i przekazania określonego genotypu, gdyż oprócz sfery biologicznej dotyczy ono również duchowej. Dogmat Bożego macierzyństwa nie mówi, że Bóg jako Bóg posiada matkę, ani że Maryja jest Matką Boskiej natury Jezusa Chrystusa. Głosi natomiast, że jest Ona prawdziwą Matką człowieka, który jest jednocześnie Bogiem. Jest Matką Boga, bo w Niej ukształtowała się ludzka natura Jezusa, zjednoczona od pierwszej chwili swojego istnienia ze Słowem Bożym, drugą Osobą Trójcy Świętej.

Uważna analiza tekstów Nowego Testamentu mówiących o Maryi wskazuje, że tytuł Bożej Rodzicielki ma solidne podstawy biblijne. W scenie zwiastowania jest powiedziane, że Maryja będzie Matką Syna Bożego: „Duch Święty zstąpi na Ciebie i moc Najwyższego osłoni Cię. Dlatego też Święte, które się narodzi, będzie nazwane Synem Bożym" (Łk 1, 35). Maryja jest tu więc ukazana jako nowe mieszkanie Boga, Namiot Przymierza, w którym Bóg zamieszkał pośród ludzi.

Z kolei w perykopie nawiedzenia Ewangelista dostrzega w Maryi nową Arkę Przymierza, miejsce obecności Boga Wcielonego. Dlatego Elżbieta odkrywa w Niej z radością „Matkę swojego Pana” (Łk 1, 43). Zarysowana przez Łukasza analogia sugeruje, że Pan, którego Maryja jest Matką, jest tym samym Panem, który przebywał w Arce. We wspomnianym wyrażeniu z Łk 1, 43 zostaje użyte słowo Kyrios, będące w Septuagincie przekładem imienia Bożego.

Macierzyństwo Maryi wykracza daleko poza wymiar czysto biologiczny. Według ojców Kościoła Maryja była bardziej błogosławioną przez to, że nosiła Chrystusa w sercu, niż przez to, że nosiła Go w ciele. Święty Augustyn powie, że „zanim Maryja poczęła Jezusa w swoim łonie, już Go przyjęła i poczęła w swojej duszy przez wiarę". Dlatego odnoszą się do Niej nie tylko słowa: „Błogosławione łono, które Cię nosiło, i piersi, które ssałeś”, lecz także i przede wszystkim: „Błogosławieni, którzy słuchają słowa Bożego i zachowują je" (Łk 11, 27-28).

W encyklice Deus caritas est Benedykt Xvi napisze:

Ona, będąc wewnętrznie przeniknięta Słowem Bożym, może stać się Matką Słowa Wcielonego. W końcu: Maryja jest kobietą, która kocha. Jak mogłoby być inaczej? Jako wierząca, która w wierze myśli zgodnie z myślą Bożą i pragnie według Bożej woli, może być jedynie niewiastą, która kocha. Wyczuwamy to w cichych gestach, o których mówią ewangeliczne opowiadania o dzieciństwie. Widzimy to w delikatności, z jaką w Kanie dostrzega potrzebę małżonków i przedstawia ją Jezusowi. Widzimy to w pokorze, z jaką przyjmuje 
to, że pozostaje w cieniu w okresie publicznego życia Jezusa, wiedząc, że Syn musi teraz założyć nową rodzinę i że godzina Matki nadejdzie dopiero w chwili krzyża, która będzie prawdziwą godziną Jezusa (por. J 2, 4; 13, 1). Wówczas, gdy uczniowie uciekną, Ona pozostanie u stóp krzyża (por. J 19, 25-27); później, w godzinie Pięćdziesiątnicy, oni będą garnąć się do Niej w oczekiwaniu Ducha Świętego (por. Dz 1, 14) .

Zarówno scena zwiastowania, jak i inne teksty maryjne Nowego Testamentu ukazują, że wcielenie Słowa jest przede wszystkim dziełem Bożej łaski. To decydujące wydarzenie w historii przymierza człowieka z Bogiem. Bóg jest tym, który pierwszy podejmuje inicjatywę i działa. Zstępując w ludzką rzeczywistość, wybiera czas, miejsce, środki, okoliczności i osoby, przez które realizuje swoje zamiary. Dlatego rozważając rolę Maryi, kierujemy nieustannie naszą uwagę na Boga, którego dziełem jest Jej wybranie. $\mathrm{Z}$ tego względu mariologia jest $\mathrm{w}$ całym tego słowa znaczeniu teologią, a kult maryjny - czcią oddawaną Bogu. Znaczenie łaski w tajemnicy Bożego macierzyństwa podkreśli św. Jan Paweł II w swojej encyklice o Maryi:

Od pierwszej chwili poczęcia, czyli zaistnienia na ziemi, należy Ona do Chrystusa, ma udział w zbawczej łasce uświęcającej oraz w tej miłości, która swój początek znajduje w „Umiłowanym”, w Synu Ojca Przedwiecznego, który poprzez Wcielenie stał się Jej rodzonym Synem. Dlatego, za sprawą Ducha Świętego, w wymiarze łaski, czyli uczestnictwa Bożej natury, Maryja otrzymuje życie od Tego, któremu w porządku ziemskiego rodzenia sama dała ży ci e jako Matka. Liturgia nie waha się nazywać Ją „Rodzicielką swego Stworzyciela" i pozdrawiać Ją słowami, które Dante Alighieri wkłada w usta św. Bernarda: „Córo Twego Syna”. A ponieważ to „nowe życie” Maryja otrzymuje w takiej pełni, jaka odpowiada miłości Syna do Matki, a więc godności Bożego macierzyństwa - stąd przy zwiastowaniu anioł nazywa Ją „łaski pełną””.

W piśmiennictwie Pawła Florenskiego (1882-1937) znajdujemy przekonanie o powołaniu człowieka do rodzenia, co jest skutkiem łączności Boga i stworzenia. Rosyjski myśliciel zauważył, że rodzenie przebiega na wiele sposobów. Jednak jego szczytem było zrodzenie Jezusa Chrystusa.

\footnotetext{
6 Benedykt Xvi, Encyklika Deus caritas est o miłości chrześcijańskiej [dalej: DCE], 41.

7 Jan Paweł II, Encyklika Redemptoris Mater o błogosławionej Maryi Dziewicy w życiu pielgrzymującego Kościoła [dalej: RM], 10.
} 
Rozwijając w sobie dar obrazu i podobieństwa, Maryja stawała się coraz bardziej dla innych, nie ograniczała się do samej siebie, do swojego „ego”. Florenski podkreślał wielokrotnie, że człowiek zwrócony ku Bogu napełnia się płodnością ${ }^{8}$.

\subsubsection{Sens macierzyństwa Bożego}

Najważniejszym celem macierzyństwa Maryi było włączenie Boga w ludzkość. Syn Boży przez Maryję stał się człowiekiem. Maryja nie była sensem, lecz środkiem i narzędziem wcielenia. Oczywiście nie można Jej redukować do narzędzia biernego i odbierać Jej swobody, gdyż w swojej wolności wypowiada Ona fiat: „Niech mi się stanie według Twego słowa” (Łk 1, 38). Nieporównywalna z niczym wielkość Maryi płynie z Jej niezwykłego związku z Bogiem, z tej jedynej i niepowtarzalnej relacji określanej jako macierzyństwo Boże. Używając terminu „macierzyństwo”, który pojawił się w teologii stosunkowo późno (xviı wieku), należy pamiętać, że nie chodzi tu o abstrakcyjną „własność” Maryi, którą można rozważać samą w sobie, lecz o relację osobową - tajemniczy związek człowieka z Bogiem.

Związku tego nie da się oczywiście porównać do więzi trynitarnych między Osobami Boskimi ani też do złączenia człowieczeństwa i bóstwa w Osobie Jezusa, czyli do unii hipostatycznej. Mimo to jest to najgłębszy i najdoskonalszy związek, jaki istnieć może między Osobą Boską i osobą ludzką, między Stworzycielem a stworzeniem. Należy pamiętać, że - jak precyzuje metafizyka - Bóg jest niezmienny i każda nowa więź z Nim jest nowa jedynie ze strony stworzenia. W przypadku Maryi Jej Boże macierzyństwo nie powoduje żadnej zmiany w Bogu, lecz jest przyczyną zasadniczej zmiany w Niej samej: skutkuje Jej niezwykłym wyniesieniem. To na Bożym macierzyństwie opiera się wyjątkowość Maryi. Bez Bożego macierzyństwa bez tej nowości w Niej - Jej osobiste przymioty i cechy, słowa i czyny, tytuły i określenia nie miałyby takiego sensu i znaczenia.

Macierzyństwo biologiczne było poprzedzone zrodzeniem Jezusa w wierze - jest więc ono skutkiem macierzyństwa duchowego Maryi, które odnosi się do wszystkich wierzących w Chrystusa. W encyklice Redemptoris Mater czytamy:

8 Por. Z. J. Kijas, Maryja $w$ tajemnicy wcielenia $w$ świetle antropologii trynitarnej Pawła Florenskiego, SM 2 (2000) nr 1, s. 132-155. 
Jeśli przez wiarę Maryja stała się Rodzicielką Syna, którego dał Jej Ojciec w mocy Ducha Świętego, zachowując nienaruszone Jej dziewictwo, to w tejże samej wierze odnalazła Ona i przyjęła ów inny wymiar macierzyństwa, który Jej Syn objawił w czasie swego mesjańskiego posłannictwa. Można powiedzieć, że wymiar ten był udziałem Matki Chrystusa od początku, od chwili poczęcia i narodzin Syna. Od tego momentu była Tą, która uwierzyła. Jednak w miarę jak odsłaniało się Jej oczom i duchowi posłannictwo Syna, Ona sama jako Matka otwierała się ku tej „nowości” macierzyństwa, jakie miało stawać się Jej udziałem przy boku Syna?

Macierzyństwo Boże można rozważać z trzech różnych punktów widzenia: jako wzór, jako zasadę i jako cel. Taki sposób rozważania pozwala ukazać jedyną i niepowtarzalną relację Maryi do Boga, który według wiary chrześcijańskiej istnieje w Trójcy Osób. Aspekt trynitarny mariologii podkreśla również Konstytucja dogmatyczna o Kościele, stwierdzając, że Maryja „jest rodzicielką Syna Bożego i dlatego najbardziej umiłowaną córką Ojca i przybytkiem Ducha Świętego"10.

Poddajmy teraz głębszej analizie tę potrójną relację Maryi do Trzech Osób Boskich. Pierwszy jej aspekt to Boże macierzyństwo jako wzór (relacja do Boga Ojca). Macierzyństwo Maryi jest Boże, gdyż może być rozważane w relacji do Bożego ojcostwa. Istnieje pewne podobieństwo między ojcostwem Bożym a macierzyństwem Maryi - należy jednak pamiętać, że chodzi tu od dwie zupełnie różne płaszczyzny. Bóg Ojciec, wprawdzie odwiecznie i według natury Boskiej, oraz Maryja, chociaż w czasie i według natury ludzkiej, mają za Syna jedną i tę samą Osobę. Ten niezwykły fakt, to podstawowe podobieństwo, „wciąga Boże macierzyństwo, niczym tajemniczego satelitę, w orbitę Bożego ojcostwa" ${ }^{11}$. Z pewnością relacja Maryi do Boga Ojca domaga się obszerniejszej analizy. Warto jednak zaznaczyć Jej oddanie się woli Jahwe, Jej modlitwę i zjednoczenie z Bogiem Ojcem ${ }^{12}$.

Nawiązując do wypowiedzi ojców Kościoła, którzy stale podkreślają rolę wiary Maryi w tajemnicy wcielenia, odnaleźć możemy jeszcze inne podobieństwo. Podobnie jak odwieczne ojcostwo, macierzyństwo Maryi jest owocem aktu duchowego, aktu wiary. Rozpatrując tajemnicę pochodzenia

9 RM 20.

10 KK 53.

11 R. Laurentin, Matka Pana. Traktat mariologiczny, dz. cyt., s. 147.

12 Por. D. Mastalska, Maryja rozmiłowana w Ojcu, SM 1 (1999) nr 4, s. 11-29. 
Syna Bożego od Ojca w Trójcy Świętej, mówimy - przez analogię - o p o częciu Słowa oraz o zrodzeniu Słowa. Maryja w tajemnicy wcielenia poczyna duchowo przez wiarę i rodzi fizycznie w swoim ciele Chrystusa. Podobieństwo do ojcostwa Bożego mieści się również w fakcie dziewiczego poczęcia, które sprawia, że Maryja w pewnym sensie sama tylko ma udział w zrodzeniu Jezusa, daje Mu pełnię fizycznego człowieczeństwa i przez to tym dobitniej odtwarza obraz odwiecznego zrodzenia.

Kolejny aspekt to macierzyństwo Boże jako zasada (relacja do Ducha Świętego). W adhortacji apostolskiej Marialis cultus Paweł vi podkreślił, że „uświęcające działanie Ducha Świętego w Dziewicy Nazaretańskiej jest szczytowym momentem Jego poczynań w historii zbawienia”"13. Dokument przypomina, że ojcowie i pisarze Kościoła przypisywali działaniu Ducha Świętego nie tylko wiarę, nadzieję i miłość Maryi, lecz także „siłę umacniającą Jej posłuszeństwo woli Bożej; męstwo, które podtrzymywało Ją cierpiącą pod krzyżem"14.

Zasadniczą rolę odgrywa jednak Duch Święty w tajemnicy wcielenia. To On poświęcił i uczynił płodnym dziewictwo Maryi. Działanie Ducha Świętego przy zwiastowaniu jest przedłużeniem Jego działania w Trójcy Świętej i zasadą Jego działania w Kościele. Duch Święty jest bowiem, jak głosi teologia, więzią Trójcy. On zespala również poszczególne członki w jedno Mistyczne Ciało Chrystusa. Fundamentem tej więzi eklezjalnej jest głęboka i jedyna łączność pomiędzy Słowem Bożym i niewiastą, w której stało się Ono ciałem. Dlatego istotne znaczenie ma obecność Maryi pośród młodego Kościoła oczekującego na dzień Pięćdziesiątnicy. Maryja jest nie tylko pierwowzorem Kościoła w jego zjednoczeniu z Chrystusem, lecz także żywą świątynią Ducha, gdzie dokonuje On wszczepienia Słowa i wzrostu Słowa w rodzaju ludzkim.

Trzeci punkt widzenia pozwala rozważać macierzyństwo Boże ze względu na cel (w relacji do Syna Bożego). Maryja jest nie tylko matką na wzór Boga (Ojca) i Matką za sprawą Boga (Ducha Świętego), lecz także i przede wszystkim Matką Boga (Syna Bożego). Ta ostatnia prawda jest najważniejsza i jej podporządkowane są dwie pozostałe: „Duch Święty wzoruje macierzyństwo Maryi na odwiecznym rodzeniu Syna przez Ojca,

${ }^{13}$ Paweł vi, Adhortacja Marialis cultus o należytym kształtowaniu i rozwijaniu kultu Najświętszej Maryi Panny [dalej: MC], 26.

${ }^{14}$ Tamże. 
aby uczynić je godnym Syna Bożego"15. Przez Maryję Bóg nawiązał zbawczy kontakt z ludzkością. Soteriologia uczy, że przyjęcie natury ludzkiej przez Boga było koniecznym warunkiem odkupienia rodzaju ludzkiego. W Maryi Słowo stało się ciałem, Syn Boży stał się jednym z ludzi, aby móc ich skutecznie reprezentować wobec Ojca. Maryja ochrania niejako prawdziwą bliskość Boga wobec ludzi, broni realizmu wcielenia przeciwko wszelkim formom doketyzmu, ogłasza światu Emmanuela, jedynego Syna Bożego prawdziwie obecnego wśród nas ${ }^{16}$.

\subsection{Zawsze Dziewica}

W chrześcijańskiej wierze przekonanie o Bożym macierzyństwie Najświętszej Maryi Panny, najważniejsza prawda mariologii, łączyło się zawsze mocno z prawdą o Jej dziewictwie. Również ta prawda, wypowiadana wielokrotnie przez Synody i Sobory, umieszczana w najstarszych wyznaniach wiary, stanowiła niekwestionowane dobro całego Kościoła. Żaden z szesnastowiecznych reformatorów nie miał wątpliwości, że Maryja zrodziła Zbawiciela jako dziewica. Jeżeli przekonanie, że Maryja jest Matką Bożą, stanowi najważniejszą prawdę mariologii, to wiara w dziewictwo Maryi jest pierwszą w porządku chronologicznym, czyli najstarszą prawdą maryjną. Teksty Nowego Testamentu, zwłaszcza zaś pierwsza i trzecia Ewangelia, świadczą wyraźnie o tym, że Jezus „narodził się z Maryi Dziewicy, za sprawą Ducha Świętego" (Łk 1, 34; Mt 1, 18. 25). Tytuł Dziewicy stał się w teologii i pobożności maryjnej synonimem imienia Maryi określanej najczęściej jako Beata Virgo Maria - Najświętsza Maryja Panna, czy - jak to tłumaczą dzisiejsze dokumenty Kościoła -Błogosławiona Dziewica Maryja.

$\mathrm{Z}$ biegiem czasu w świadomości wiernych utrwaliło się przekonanie, że Maryja pozostała zawsze Dziewicą. Wiara w trwałe (wieczne) dziewictwo Maryi ma trzy aspekty, wypracowane skrupulatnie przez tradycję teologiczną. Mówi ona, że Maryja poczęła Jezusa w sposób dziewiczy (virginitas ante partum), zrodziła Go jako Dziewica (virginitas in partu) oraz pozostała Dziewicą po Jego narodzeniu (virginitas post partum).

Teologia tradycyjna, mówiąc o Maryi zawsze Dziewicy, akcentowała często w swoich rozważaniach aspekt biologiczny dziewictwa, a więc

${ }_{15}$ R. Laurentin, Matka Pana. Traktat mariologiczny, dz. cyt., s. 150.

${ }^{16}$ Por. S. Budzik, Maryja w tajemnicy Chrystusa i Kościoła, dz. cyt., s. 63-76. 
nienaruszalność (integralność cielesną), jak również aspekt etyczno-moralny, a więc wolność od jakiegokolwiek grzechu, sprzecznego z cnotą czystości. Za mało podkreślano aspekty teologiczny i duchowy dziewictwa, polegający na całkowitym oddaniu się do dyspozycji Stwórcy. Święty Jan Paweł II trafnie zauważa, że

Maryja, która przy zwiastowaniu wyznaje swoje dziewictwo („Jakże się to stanie, skoro nie znam męża?"), uwierzyła, że z mocy Najwyższego, za sprawą Ducha Świętego, stanie się Matką Syna Bożego zgodnie z objawieniem anioła: „Święte, które się narodzi, będzie nazwane Synem Bożym" (Łk 1, 35)

\subsubsection{Przekaz doktrynalny}

Nauka o dziewictwie Maryi nie była wprawdzie nigdy przedmiotem uroczystej definicji Kościoła, jednak od II wieku aż po czasy współczesne przypominana jest w niezliczonych wypowiedziach ojców i pisarzy Kościoła oraz w dokumentach Magisterium jako jeden z najbardziej oczywistych elementów prawdy objawionej, która wymaga od chrześcijanina odpowiedzi wiary.

Prawdę o dziewiczym poczęciu Jezusa przez Maryję (virginitas ante partum) głoszą już najstarsi ojcowie Kościoła (Ignacy Antiocheński, Polikarp, Justyn, Ireneusz), opierając się na fundamencie biblijnym. Wiara ta sformułowana jest również w najwcześniejszych symbolach wiary, używanych podczas liturgii, skąd przejęta została do wyznań wiary trzeciego i czwartego stulecia. Skład Apostolski mówi o Chrystusie jako poczętym z Ducha Świętego i narodzonym z Maryi Dziewicy ${ }^{18}$. Sobór Konstantynopolitański w roku 381 wyznaje: „który dla nas ludzi i dla naszego zbawienia zstąpił z nieba i przyjął Ciało za sprawą Ducha Świętego z Maryi Dziewicy i stał się człowiekiem"19.

Jednoznaczne wyznanie wiary w dziewictwo Maryi po narodzeniu Chrystusa zawarte jest w tytule Aeiparthenos (zawsze Dziewica), znanym od IV wieku. Z czasem tytuł „Panna” (Virgo) stał się niejako imieniem własnym Maryi. Dogmat ten powtarzany jest niemal we wszystkich wypowiedziach doktrynalnych Kościoła mówiących o macierzyństwie Maryi. Wiara w Jej dziewictwo zawsze wiązała się bowiem z wiarą w Jezusa Chrystusa jako

\footnotetext{
17 RM 14.

${ }_{18}$ Zob. Apostolski skład wiary, [w:] BF IX 4.

19 BF IX 10.
} 
Boga - Człowieka, który począł się z Ducha Świętego i narodził się z Maryi Dziewicy. Stąd teologia dziewictwa Maryi pozostaje w służbie chrystologii ${ }^{20}$.

Na potwierdzenie wiary w trwałe dziewictwo Maryi (virginitas post partum) można również przytoczyć liczne świadectwa kościelnej Tradycji i wypowiedzi Urzędu Nauczycielskiego. Mimo pojedynczych prób dosłownego rozumienia wypowiedzi o braciach i siostrach Jezusa (Tertulian, Helwidiusz, Bonosus) największe autorytety Kościoła starożytnego, jak Ambroży, Augustyn czy Hieronim, wypowiedziały się jednoznacznie za prawdą o trwałym oddaniu się Maryi Bogu w dziewictwie. Określenie Maryi jako Dziewicy spotykamy po raz pierwszy u św. Ignacego Antiocheńskiego, w najstarszym źródle pozabiblijnym. Twierdził on, że Jezus Chrystus narodził się z Maryi Dziewicy według Bożego planu zbawienia. To przekonanie - potwierdzone również przez innych pisarzy apostolskich i ojców Kościoła - znalazło swój uroczysty wyraz w IV wieku w formule określającej Maryję jako semper virgo - „zawsze Dziewicę“.

II Sobór w Konstantynopolu w 553 roku wprowadził tę formułę do swoich dokumentów, mówiąc o dwóch narodzinach Chrystusa, który, zrodzony przed wiekami z Ojca, „przyjął ciało od świętej i chwalebnej Bożej Rodzicielki zawsze Dziewicy Maryi” ${ }^{21}$. Na ten temat pisał papież Syrycjusz (zm. 399) w liście do biskupa Anyzjusza w Tesalonice, odrzucając pogląd, jakoby Maryja po urodzeniu Chrystusa miała jeszcze inne dzieci (tzw. „braci Jezusa"). Trwałego dziewictwa Najświętszej Maryi Panny bronił ponadto w 449 roku papież Leon I Wielki w liście do patriarchy Flawiana, biskupa Konstantynopola:

Ten sam wiecznego Rodzica współwieczny Jednorodzony „narodził się z Ducha Świętego i z Maryi Dziewicy". A te doczesne narodziny nic nie ujęly i nic nie dodały tamtym Boskim i odwiecznym narodzinom, ale jedynie dążyły do naprawienia zwiedzionego człowieka. Miały bowiem odnieść zwycięstwo nad śmiercią i swoją mocą zniszczyć diabła, który dzierżył władzę śmierci. Nie mogliśmy bowiem pokonać sprawcy grzechu i śmierci bez udziału w naszej naturze i bez przyjęcia jej na siebie Tego, którego ani grzech nie mógł skazić, ani śmierć nie mogła związać. Został bowiem poczęty z Ducha Świętego w łonie

\footnotetext{
${ }^{20}$ Por. S. C. Napiórkowski, Maryja w teologii, [w:] EK, t. 12, Lublin 2008, k. 18.

${ }^{21}$ BF VI 12.
} 
Dziewicy-Matki, która wydała Go na świat bez naruszenia swego dziewictwa, jak Go była poczęła w nienaruszonym dziewictwie ${ }^{22}$.

Do innych tekstów magisterialnych głoszących prawdę o dziewictwie Maryi należy zaliczyć także akta Synodu Laterańskiego z 649 roku, który uczył:

Jeżeli ktoś nie wyznaje według nauki świętych Ojców, że święta zawsze Dziewica i niepokalana Maryja jest prawdziwie i właściwie Boga Rodzicielką, ponieważ samego Boga-Słowo zrodzonego z Ojca przed wszystkimi wiekami, a w ostatnich czasach w sposób szczególny i prawdziwy bez nasienia poczęła z Ducha Świętego, bez naruszenia dziewictwa porodziła i pozostała także dziewicą po narodzeniu - niech będzie wyklęty ${ }^{23}$.

Tę prawdę wiary głosił też Symbol Toledański z 675 roku:

Wierzymy, że Ojciec i Syn, i Duch Święty są jednej substancji, nie twierdząc jednak, jakoby Maryja Dziewica stała się matką całej Trójcy, lecz tylko Syna, który sam jeden przybrał naszą naturę w jedności swojej osoby. Trzeba także wierzyć, że Wcielenia Syna Bożego dokonała cała Trójca, jako że jej dzieła są nierozdzielne. Jednakże sam tylko Syn „przyjął postać sługi” (Flp 2, 7) w pojedynczości osoby, a nie w jedności Boskiej natury; w tym, co jest właściwe Synowi, a nie w tym, co jest wspólne Trójcy. A postać tę włączył do jedności swej osoby, tak że Syn Boży i Syn Człowieczy jednym są Chrystusem, to znaczy Chrystus, mając te dwie natury, składa się z trzech substancji: substancji Słowa, którą należy odnieść do istoty samego tylko Boga, oraz substancji ciała i substancji duszy, obu przynależnych prawdziwemu człowiekowi ${ }^{24}$.

Elementem dogmatu o trwałym dziewictwie Maryi, potwierdzonym przez tradycję, jest przekonanie o dziewiczym zrodzeniu Chrystusa (virginitas in partu). W tym kontekście tradycja mówiła również o tym, że zrodzenie to dokonało się w sposób bezbolesny. Bóle rodzenia są według $\mathrm{Rdz}$ 3, 16 znakiem głębokiego zachwiania równowagi stworzenia wskutek upadku człowieka oraz zerwania więzi z Bogiem. Narodzenie Chrystusa, jako początek nowego życia i zapowiedź wyzwolenia człowieka z grzechu, stoi

\footnotetext{
22 BF VI 7.

23 BF VI 81.

${ }^{24}$ BF IX 25.
} 
więc pod znakiem radości, którą przeżywa Maryja rodząca Jezusa. Sobór Watykański II używa subtelnej formuły liturgicznej mówiącej, że Chrystus przez swoje narodzenie nie naruszył dziewictwa Maryi, ale je uświęcił ${ }^{25}$.

Entuzjastami tej nauki było wielu chrześcijańskich myślicieli, filozofów i teologów, jak np. św. Bernard z Clairvaux, św. Tomasz z Akwinu, Aleksander z Hales (ok. 1183-1245) i św. Albert Wielki (ok. 1193/1205-1280). Największym z nich był jednakże angielski franciszkanin Jan Duns Szkot. Warto zauważyć, że dogmat o wiecznym dziewictwie Najświętszej Maryi jest uznawany nie tylko w Kościele katolickim, lecz także w Kościele prawosławnym czy innych Kościołach Wschodu.

O dziewictwie Maryi poucza także Katechizm Kościoła katolickiego. Czytamy w nim: „Pogłębienie wiary w dziewicze macierzyństwo Maryi doprowadziło Kościół do wyznania Jej rzeczywistego i trwałego dziewictwa, także w zrodzeniu Syna Bożego, który stał się człowiekiem. Istotnie, narodzenie Chrystusa «nie naruszyło Jej dziewiczej czystości, lecz ją uświęciło»" ${ }^{26}$. Z faktu dziewiczego macierzyństwa Maryi autorzy Katechizmu wyprowadzają także wnioski natury chrystologicznej i soteriologicznej. Dziewictwo Maryi nie może być zawężane jedynie do Niej samej; ma ono swoje konsekwencje dla całych dziejów zbawczych. „Jezus począł się z Ducha Świętego w łonie Dziewicy Maryi, ponieważ jest Nowym Adamem, który daje początek nowemu stworzeniu: «Pierwszy człowiek z ziemi ziemski, drugi Człowiek - z nieba» (1 Kor 15, 47). Człowieczeństwo Chrystusa od chwili poczęcia jest napełnione Duchem Świętym, ponieważ Bóg «z niezmierzonej obfitości udziela Mu Ducha» $(\mathrm{J} 3,34)$. Z «pełności» Tego, który jest Głową odkupionej ludzkości, «wszyscyśmy otrzymali - łaskę po łasce» $(\mathrm{J} 1,16){ }^{{ }^{22}}$. Jezus, który jest Nowym Adamem, przez dziewicze poczęcie zapoczątkowuje nowe narodziny dzieci przybranych w Duchu Świętym przez wiarę. Dlatego nasz udział w życiu Bożym nie pochodzi „z krwi ani z żądzy ciała, ani z woli męża, ale z Boga” (J 1, 13). „Przyjęcie tego życia jest dziewicze, ponieważ jest ono całkowicie udzielane człowiekowi przez Ducha. Oblubieńczy sens powołania ludzkiego w relacji do Boga wypełnia się doskonale w dziewiczym macierzyństwie Maryi”28.

\footnotetext{
${ }^{25}$ Por. KK 57.

${ }^{26}$ KKK 499.

27 KKK 504 .

${ }^{28}$ KKK 505.
} 


\subsubsection{Wymowa teologiczna}

Jakkolwiek przekonanie o dziewictwie Maryi w obszarze chrześcijańskiej wiary było dość oczywiste, przez zewnętrznych obserwatorów kwalifikowane było ono jako kłamstwo czy też mit. Pierwsze zarzuty padły ze strony żydowskiej, która oskarżała Maryję o cudzołóstwo. W dziele Orygenesa Przeciw Celsusowi z III wieku znajdujemy przekaz Talmudu o cudzołóstwie Maryi. Czytamy tam, że „matka Jezusa została wypędzona przez swego męża, cieślę, pod zarzutem cudzołóstwa, gdy była brzemienna po stosunku z żołnierzem, niejakim Panterą" ${ }^{29}$. Z kolei politeistyczny świat tę prawdę chrześcijańskiej wiary przyjmował jako mit, czyli formę narracji o związkach bogów ze śmiertelnymi kobietami. Stworzono jeszcze wiele innych teorii, którymi próbowano tłumaczyć dziewicze zrodzenie Jezusa przez Maryję. Ich powstawanie nasiliło się w dobie oświecenia, kiedy kwestionowano historyczność Jezusa i tym samym wiele elementów chrześcijańskiego objawienia. Dziewicze poczęcie Jezusa próbowano również zanegować za pomocą idei „teologumenu” ${ }^{\circ}$. Na przełomie XIx i xx wieku liberalni teologowie protestanccy wysunęli tezę, że pierwsi chrześcijanie, aby podbudować swoją wiarę, stworzyli wiele historii i legend, m.in. o poczęciu Jezusa ${ }^{31}$.

Po prezentacji tradycyjnej nauki Kościoła i niektórych stwierdzeń, które klasyfikują dziewictwo Maryi jako kłamstwo, mit czy też niehistoryczność, należy zastanowić się głębiej nad sensem teologicznym dogmatu o dziewictwie Matki Chrystusa. Podobnie jak w wypadku prawdy o Bożym macierzyństwie Maryi, należy go interpretować w aspekcie chrystologicznym, zwłaszcza zaś w kontekście wiary paschalnej, znajdującej się w centrum nowotestamentalnego przepowiadania. Istnieje głęboka paralela między przejściem Chrystusa zmartwychwstałego z ludzkiej historii do chwały Ojca a samym Jego wejściem w dzieje świata - wcieleniem. Chodzi tu o dwa momenty, w których dokonuje się przekroczenie granicy pomiędzy skończonością a transcendencją i które dlatego są jedyne i niezwykłe. Jezus wchodzi w ludzką historię jako ktoś przychodzący z zewnątrz.

${ }^{29}$ Orygenes, Przeciw Celsusowi 1, 32, tłum. S. Kalinkowski, E. Stanula, W. Myszor, Warszawa 1977, s. 25 (Pisma Starochrześcijańskich Pisarzy, 17, z. 1).

${ }^{30}$ Przez „teologumen” rozumiemy twierdzenie teologiczne, nieposiadające bezpośredniego uzasadnienia w Piśmie Świętym ani też w Tradycji, ani w orzeczeniach dogmatycznych Kościoła. Przez „teologumen” teologowie pragną wyrazić jakiś aspekt doświadczenia wiary (E. Przywara, K. Rahner).

${ }^{31}$ Por. J.-P. Torrell, Dziewica Maryja w wierze katolickiej, przeł. M. Szewc-Osiecka, Poznań 2013, s. 62-67. 
Z tajemnicy wcielenia i odkupienia wynikają zarówno dla teologii, jak i antropologii chrześcijańskiej nowe i głębokie treści. Od tego niezwykłego momentu nic, co ludzkie, nie jest już Bogu obce, a to, co Boskie, nie jest już dla człowieka nieosiągalne. Na tym tle trzeba rozważać dogmat dziewictwa Maryi w kategorii znaku. Teoretycznie rzecz biorąc, tajemnica wcielenia mogła się dokonać przez unię hipostatyczną Słowa Bożego z człowiekiem, który począłby się tak jak każdy inny człowiek, z ojca i matki. Nie byłoby również niczym szokującym czy nienormalnym, gdyby Jezus był pierworodnym synem wielodzietnej rodziny. Skoro jednak stało się inaczej, skoro Bóg sam dał nam znak (por. Iz 7, 14), to zadaniem teologii jest jego odczytanie i interpretacja.

\subsubsection{Dziewictwo Maryi w kategorii znaku}

Przybliżmy teraz tematykę dziewictwa Najświętszej Maryi Panny, odnosząc się do kategorii znaków i ich teologicznej interpretacji. Można wyróżnić cztery takie znaki: jedynego synostwa Bożego, darmowości zbawienia, nowego stworzenia i integralności.

Znak jedynego synostwa Bożego. Dziewicze poczęcie Jezusa podkreśla, że jedynym Ojcem Jezusa jest Bóg. Niektórzy ojcowie Kościoła mówili o trzech narodzinach Jezusa - co weszło to do liturgii Bożego Narodzenia. Pierwszym było to przed wiekami - z Ojca, drugim z Maryi Dziewicy i trzecim - w duszy człowieka wierzącego. Dziewicze narodzenie z Maryi jest znakiem dla obu pozostałych narodzin. Aby podkreślić odwieczne synostwo Słowa, Bóg sprawił, że Jezus nie miał ojca według ciała. Chodziło o ukazanie prawdy, że Ojciec Niebieski jako Pan i Stwórca wszelkiego życia jest jedynym źródłem i zasadą ludzkiej egzystencji Jezusa. Narodziny Jezusa z Maryi Dziewicy odnoszą się również do tajemnicy Trójcy Świętej - Ojciec rodzi odwiecznie Syna równego sobie w Bóstwie, nie doznając przy tym sam żadnego uszczerbku swojej Boskości i chwały. I wreszcie dziewicze zrodzenie Jezusa rzutuje na Kościół, którego Maryja jest pierwowzorem. Według mariologii Soborowej Kościół odnajduje sam siebie w obrazie dziewiczej Matki, gdyż podobnie jak Ona rodzi do nowego życia łaski synów z Ducha Świętego poczętych i z Boga zrodzonych. Na wzór Maryi Dziewicy dochowuje również oblubieńczej wierności Chrystusowi, zachowując niewzruszenie wiarę, nadzieję i miłość.

Znak darmowości zbawienia. Dziewicze poczęcie i zrodzenie Jezusa jest również znakiem łaskawości Boga, który darmo daje ludziom 
swoje zbawienie. Wcielenie Jezusa nie jest dziełem ludzkiej woli czy zasługą ludzkiego wysiłku, lecz owocem działania samego Boga (por. J 1, 13).

$\mathrm{Znak}$ nowego stworzenia. Wcielenie jest stwórczym dziełem Boga, który czyni coś absolutnie nowego, posługując się istniejącym stworzeniem. Duch Święty, który osłania Maryję, uważnemu czytelnikowi Biblii przypomina tego Ducha, który unosił się nad wodami w dniach stworzenia świata. Wcielenie jest więc nowym stworzeniem, początkiem ożywczego i najważniejszego etapu historii zbawienia. Człowiek stworzony na obraz Stwórcy utracił przez grzech podobieństwo Boże. Ktokolwiek przychodził na ten świat zrodzony z ojca i matki, popadał w zależność od grzechu i zła, nie tylko własnego, lecz także tego zła, za które sam nie był odpowiedzialny. Dziewicze narodzenie Jezusa za sprawą Ducha Świętego jest czymś zupełnie nowym na historycznym szlaku ludzkich narodzin. To narodziny nowego nieba i nowej ziemi (por. Ap 21, 1). Z tego wynika, że dogmat dziewiczego poczęcia dotyka samego centrum tajemnicy Chrystusa.

Znak integralnego dziewictwa. Trwałe dziewictwo Maryi jest konsekwencją Jej fiat wypowiedzianego przy zwiastowaniu, znakiem Jej całkowitej dyspozycyjności wobec Boga i Jego woli. Jest także znakiem świętości Maryi, czyli szczególnego wybrania i przeznaczenia na służbę Bogu i Jego ludowi. Tak rozumiany ideał dziewictwa dla Królestwa Niebieskiego odegrał w historii duchowości chrześcijańskiej niezwykłą rolę. Dziewictwo rozumiane jest nie tyle negatywnie, jako rezygnacja z miłości małżeńskiej, ile pozytywnie, jako całkowita i niepodzielna służba Bogu. Dziewictwo to całkowita wierność. Stąd ideał ten nie deprecjonuje w żaden sposób małżeństwa, ale dowartościowuje je jako ważną instytucję w służbie społeczeństwa i Kościoła. Szacunek i uznanie dla dziewictwa oraz ujęcie małżeństwa jako sakramentu, czyli znaku zbawienia, stanowią dwa nierozłączne elementy doktryny katolickiej.

Integralnie rozumiane dziewictwo ma także swój wymiar eklezjalny i przynosi szczególnie bogate owoce duchowe. Przynosi zobowiązania dla wszystkich wiernych, a szczególnie dla osób życia konsekrowanego:

Gdy Kościół jako Oblubienica „dochowuje wiary danej Chrystusowi”, wówczas wierność ta - chociaż w nauczaniu Apostoła stała się obrazem małżeństwa (por. Ef 5, 23-33) - posiada równocześnie znaczenie wzoru całkowitego oddania się w bezżenności „dla królestwa niebieskiego”, czyli poświęconego Bogu dziewictwa (por. Mt 19, 11-12; 2 Kor 11, 2). Takie właśnie dziewictwo - na wzór Dziewicy z Nazaretu - jest źródłem szczególnej duchowej płodności: źródłem 
macierzyństwa w Duchu Świętym. Kościół jednakże strzeże również wiary otrzymanej od Chrystusa: za wzorem Maryi, która zachowywała i rozważała w swym sercu (por. Łk 2, 19.51) wszystko to, co dotyczyło Syna Bożego, Kościół zobowiązuje się strzec Słowa Bożego, zgłębiać jego bogactwo z mądrością i rozwagą, aby w każdej epoce dawać wierne świadectwo wszystkim ludziom ${ }^{32}$.

Nie tylko w przestrzeni czystości, lecz także ubóstwa i posłuszeństwa Maryja jest niedościgłym wzorem dla osób konsekrowanych. Potwierdza to choćby już sama maryjność wszystkich zakonów i instytutów życia konsekrowanego ${ }^{33}$.

\subsubsection{Kategoria dziewictwa - współczesne rozumienie}

Dość często spotykamy się z opinią, że katolicka kwalifikacja dziewictwa jest zbyt ostro określona, sztuczna i sprzeczna z naturą. Te współczesne próby i tendencje zmierzające do zaniżenia wartości dziewictwa wynikają z wielu przyczyn, do których można zaliczyć: ogólny brak kultury czystości i wstrzemięźliwości w życiu społecznym, obniżenie przez wirtualny świat seksualnego tabu, dość powszechne praktykowanie przedmałżeńskich zbliżeń cielesnych, niewłaściwe przygotowanie w rodzinach do przyszłego małżeństwa, brak odpowiednich słów i języka wyrażających miłość seksualną czy też łatwość kontaktów erotycznych. W tym klimacie dość trudno głosić dziewictwo Maryi. Słowa „dziewica”, „dziewiczy” straciły pierwotną wartość. Z tego pojęcia chrześcijańska edukacja wyprowadza znaczenie: „świeży”, „czysty”, „nieużyty fizycznie”, „nietknięty”, „młodzieńczy”, „piękny”, „integralny”, „zwarty”, „wstrzemięźliwy”, „opanowany”. W formie zwulgaryzowanej przez „dziewicę” rozumie się dziś natomiast osobę, która jeszcze nie miała stosunku seksualnego. Jak zatem wypowiadać i przybliżać sens dziewictwa Najświętszej Maryi Panny jako współczesny wzór do naśladowania?

Teologia feministyczna w zagadnieniu dziewictwa odwołuje się do kategorii autonomii, wynikającej jeszcze z rozumienia roli Maryi w czasach starożytnego, patriarchalnego społeczeństwa. Dziewictwo Maryi oznaczało wówczas Jej emancypację i rozwiniętą samoświadomość. Maryja była zatem na tyle silna i niezwykle samodzielna, że żyła z własnego wyboru w dziewiczym stanie, czyli zyskiwała możliwość autentycznie niezależnego działania i samorealizacji. Wykazała to już w momencie zwiastowania,

32 RM 43. Por. S. Budzik, Maryja w tajemnicy Chrystusa i Kościoła, dz. cyt., s. 77-87.

33 Por. P. Warchoł, Maryja inspiracją dla osób konsekrowanych, SM 17 (2015) nr 1-4, s. 61-76. 
prowadząc dialog z wysłannikiem Jahwe. Zadała pytanie, przewidywała możliwe konsekwencje rozmowy. Teologia feministyczna odrzuciła zatem propozycję arystotelesowsko-tomistycznej filozofii naturalnej, w której Maryi przypisywano rolę jedynie czysto bierną. Rozpowszechnia ona natomiast element aktywności, aby uświadomić kobietom wysoki stopień ich autonomiczności. Można przytoczyć inne próby wyjaśnień dziewictwa, jakie zaproponowała teologia feministyczna (np. Heinrich Stirnimann, Andrew Greeley), jednakże nie zasługują one na większą uwagę, gdyż nie uwzględniają (albo uwzględniają minimalnie) momentu chrystologicznego, stanowiącego przecież konieczny fundament każdej wypowiedzi mariologicznej i maryjnej ${ }^{34}$.

Chrześcijańskiego dziewictwa nie można absolutyzować i rozważać w oderwaniu od całości życia, które ma być ukierunkowane na Boga. Dziewictwo Maryi obejmujące Jej cielesność jest integralnym elementem świadectwa, jakie dawała Ona całym swoim życiem, udowadniając, że przynależy we wszystkim do Boga.

Podsumowując, trwałe dziewictwo Maryi - przed narodzeniem Jezusa oznacza, że Maryja poczyna Chrystusa za sprawą Ducha Świętego i bez udziału mężczyzny. Dalej, trwałe dziewictwo Maryi - w narodzeniu Jezusa oznacza, że podobnie jak w Nazarecie, tak samo i w Betlejem Maryja jest ciałem i duszą oddana Jahwe. Jako Służebnica bez reszty do Niego przynależy. I wreszcie trwałe dziewictwo Maryi - po narodzeniu Jezusa - oznacza, że Maryja pozostaje na zawsze wyłączną własnością Boga i swego Syna ${ }^{35}$.

Współczesna próba interpretacji dziewictwa Maryi wyszła też spod pióra Karla Rahnera. Niemiecki teolog ujął dziewicze macierzyństwo Maryi w znaku Bożej miłości, transcendującej świat. Osoba ludzka staje się doskonała, jeśli kroczy za Chrystusem. Im bardziej człowiek wpisany jest w krąg Chrystusowego wcielenia i odkupienia, tym pełniej urzeczywistnia się jego powołanie. Maryja jest tu przypadkiem szczególnym. Mamy tu bowiem do czynienia z tzw. teologicznym „zagęszczeniem czasu”, czyli przejściem $\mathrm{z}$ protologii $\mathrm{w}$ spełnioną eschatologię $\mathrm{w}$ jednym krótkim momencie (intermedium). Według teologa $\mathrm{z}$ Freiburga prawda o dziewictwie Maryi podkreśla darmowość zbawienia, pochodzącego z wysoka. Odchodzi on od takich kategorii hermeneutycznych, jak: legenda, teologumen, mit, symbol, midrasz, które fałszują prawdę o dziewictwie. Rozwiązaniem jest

\footnotetext{
${ }^{34}$ Por. F. Courth, Mariologia. Maryja, Matka Chrystusa, dz. cyt., s. 135-137.

${ }^{35}$ Por. tamże, s. 138.
} 
według niego powiązanie dziewictwa z Bożym macierzyństwem. Nie należy pytać, dlaczego Bóg chciał, aby Maryja była dziewicą. O wiele ważniejsze jest pytanie: dlaczego Syn Boży stał się człowiekiem bez udziału ziemskiego ojca? Ponadto skoro Maryja była wolna od grzechu i pożądliwości, to Jej macierzyństwo musiało przebiegać w odmienny sposób niż u każdej innej kobiety, naznaczonej skutkami grzechu pierworodnego. Ostatecznie Rahner dziewicze macierzyństwo Maryi analizuje nie tylko personalistycznie, podkreślając antropologiczną jedność Jej osoby, lecz także jako tajemnicę ${ }^{36}$.

\subsection{Wolna od grzechu i święta}

Nauka o świętości i bezgrzeszności Maryi łączy się tematycznie z dogmatem niepokalanego poczęcia. Ponieważ jednak nauka o bezgrzeszności Maryi jest historycznie wcześniejsza, omawiamy ją w tym miejscu. Najpierw na Wschodzie pojawiły się takie określenia jak „,bezgrzeszna”, „najświętsza”, panhagia, „przeczysta”, „niepokalana”, „pełna łaski”. Miały one wyrazić, że Maryja w czasie całego życia - od początku swego istnienia - była bez jakiejkolwiek zmazy grzechu. Aby włączyć się w postępujący w Kościele proces odkrywania świętości Matki Chrystusa. Oddajmy głos Benedyktowi Xvi:

Pomiędzy świętymi wyróżnia się Maryja, Matka Pana i odzwierciedlenie wszelkiej świętości. W Ewangelii św. Łukasza znajdujemy Ją zaangażowaną w posługę miłości wobec krewnej Elżbiety, u której pozostaje „około trzech miesięcy” $(1,56)$, aby jej towarzyszyć w ostatnim okresie ciąży. Magnificat anima mea Dominum - mówi przy okazji tej wizyty - „Wielbi dusza moja Pana” (Łk 1, 46) i wyraża w ten sposób, jaki jest program Jej życia: nie stawiać siebie w centrum, ale zostawić miejsce dla Boga spotkanego zarówno w modlitwie, jak i w posłudze bliźniemu - tylko wtedy świat staje się dobry. Maryja jest wielka dlatego właśnie, że zabiega nie o własną wielkość, lecz Boga. Jest pokorna: nie chce być niczym innym jak służebnicą Pańską (por. Łk 1, 38. 48) ) $^{37}$.

${ }^{36}$ Por. W. Łaszewski, Dziewicze macierzyństwo Maryi - znak miłości transcendujacej świat w świetle teologii Karla Rahnera, SM 2 (2000) nr 1, s. 103-119.

${ }^{37}$ DCE 41. 


\subsubsection{Zarys historii}

Teksty Nowego Testamentu przedstawiają Matkę Chrystusa jako człowieka poddanego ograniczeniom ludzkiej kondycji i stojącego przed Najwyższym ze świadomością swej całkowitej zależności jako stworzenie. Ewangelie wspominają o tym, że Maryja nie od razu pojmuje sens słów i działań swojego Syna, że dręczą Ją niepokój i troska. Wynika z tego, że również i Ona musiała iść przez życie trudną drogą „W pielgrzymce wiary”, jak to formułuje soborowa konstytucja o Kościele ${ }^{38}$.

Przekonanie o świętości i bezgrzeszności Matki Bożej sięga trzeciego stulecia wiary chrześcijańskiej. Spotykamy tę naukę już u Hipolita Rzymskiego. Świętość Maryi podkreślali Efrem Syryjczyk oraz Augustyn z Hippony.

Wiara w świętość i bezgrzeszność Matki Chrystusa znalazła stałe miejsce w depozycie wiary Kościoła, poczynając od v wieku. Chrześcijaństwo greckie na określenie tej prawdy zastosowało tytuł panhagia, co można by przetłumaczyć jako „ze wszech miar święta”. Prawda ta utrwaliła się w Kościele tym łatwiej, że ma podstawę w Piśmie Świętym. Według Łukasza Maryja jest przedmiotem szczególnego upodobania Bożego, jest kecharitomene, czyli cieszy się pełnią łaski.

Naukę Kościoła o bezgrzeszności i świętości Maryi potwierdził wyraźnie Sobór Trydencki, precyzując, że Maryja była wolna również od jakiegokolwiek grzechu lekkiego. Prawda ta nabiera pełnego blasku w kontekście dogmatu o niepokalanym poczęciu, mimo że historycznie właśnie prawda o świętości i bezgrzeszności Maryi doprowadziła do pogłębienia i zdefiniowania wiary w to wydarzenie. Papież Pius Ix w bulli Ineffabilis Deus proklamującej dogmat niepokalanego poczęcia przypomina tę prawdę.

\subsubsection{Teologia doktryny}

Bezgrzeszność i świętość to dwa przejawy tej samej rzeczywistości, zarówno w ujęciu negatywnym, jak i względnie w pozytywnym. Świętość jest w pierwotnym znaczeniu cechą samego Boga, Jego synonimem. Bóg jest po „trzykroć Święty”, czyli Święty w najgłębszym tego słowa znaczeniu. W sensie pochodnym jako świętą określamy rzeczywistość stworzoną, która znajduje się w szczególnej relacji do Boga. Chodzi tu przede wszystkim o rzeczywistość osobową - dlatego mówimy „święty” o człowieku, który jest szczególniej złączony z Bogiem. W wypadku człowieka można mówić

\footnotetext{
${ }^{38}$ Por. KK 58.
} 
o świętości ontologicznej, która jest dziełem Bożej łaski, oraz o świętości etycznej, wynikającej z osobistej postawy i postępowania człowieka.

Odpowiedzią człowieka na Boże powołanie do świętości jest wiara, rozumiana jako całość postawy człowieka wobec Boga i świata. Pełna świętość osobista realizuje się więc wtedy, gdy łaska Boża spotyka się z odpowiedzią wiary człowieka. W tym znaczeniu święty nie jest „nadczłowiekiem”, ale człowiekiem sensu stricto: człowiekiem realizującym w pełni swoje człowieczeństwo. Dlatego święty jest zwłaszcza Jezus Chrystus ze względu na swą ludzką doskonałość. Miarą zaś świętości innych ludzi jest ich łączność z Chrystusem i miłość do Niego.

Świętość łączy się z miłością. Benedykt xvi wyjaśnia ją następująco:

Jest ona „łaską" (charis). Jej źródłem jest krynicznie czysta miłość Ojca do Syna, w Duchu Świętym. To miłość, którą Syn wylewa na nas. To miłość stwórcza, dzięki której istniejemy; to miłość odkupieńcza, dzięki której jesteśmy nowym stworzeniem. Miłość objawiona i urzeczywistniona przez Chrystusa (por. J 13, 1) oraz „rozlana w sercach naszych przez Ducha Świętego” (Rz 5, 5). Miłowani przez Boga, ludzie stają się podmiotami miłości i sami mają być narzędziami łaski, by szerzyć miłość Bożą i rozbudowywać „sieć miłości”39.

Na tle tych rozważań należy rozumieć naukę o doskonałej świętości czy inaczej bezgrzeszności Matki Chrystusa. Wynika ona z prawdy o Bożym macierzyństwie Maryi, a potwierdzona i zobrazowana jest w dogmacie o trwałym dziewictwie Najświętszej Maryi Panny. Jedyny i niepowtarzalny wybór łaski Bożej, który objawił się w fakcie Bożego macierzyństwa Maryi, spotkał się z Jej odpowiedzią wiary, w swym natężeniu i oddaniu odpowiadającej wielkości Bożego wybrania. Jak każda inna świętość, tak i świętość Maryi mierzy się bliskością i miłością do Jezusa - z tego względu jest więc świętością niepowtarzalną i jedyną. Świętość Maryi realizuje się całkowicie w ramach zakreślonych przez czas i okoliczności Jej życia. Droga z nazaretańskiego domu na wzgórze Golgoty jest - jak mówi Sobór pielgrzymką wiary, która wymaga poszukiwań, która zadaje pytania, która pozostawia miejsce dla tajemnicy i łaski. Jest to więc świętość na wskroś ludzka i możliwa do naśladowania.

${ }^{39}$ Benedykt Xvi, Encyklika Caritas in veritate o integralnym rozwoju ludzkim w miłości i prawdzie, 5 . 
Dotykamy tu znowu tajemnicy współdziałania wolności człowieka z łaską Boga. Nie można rozważać świętości Maryi, nie zwracając się do Tego, który był Jej Twórcą, który uczynił Jej „wielkie rzeczy”. Podziwianie Jej świętości jest podziwem dla Chrystusa, jedynego źródła łaski. Równocześnie jednak Jej odpowiedź, będąca odpowiedzią wiary przenikającej życie i postępowanie, stanowi drogowskaz dla każdego chrześcijanina. Przy wszelkich próbach konkretnego opisu świętości Maryi należy pamiętać, że zawsze pozostaną one niedoskonałe i niepełne ${ }^{40}$.

Warto zwrócić uwagę, że tajemnica świętości Maryi oraz Jej niepokalanego poczęcia jest lepiej rozumiana, gdy jest połączona ze zmartwychwstaniem Chrystusa. Coraz więcej we współczesnej teologii pisze się o związkach czterech dogmatów maryjnych z tajemnicą paschalną Jezusa. Do tej pory więcej rozważań na temat tego zagadnienia można było odnaleźć w teologii wschodniej niż zachodniej.

Maryja wpisana w misterium zmartwychwstania Jezusa sama doznaje zmartwychwstania, którym było dla Niej wniebowzięcie. Dokonało się wówczas przeobrażenie ludzkiej formy egzystencji. Już przez Boże macierzyństwo Maryja cieszyła się udziałem w owocach zmartwychwstania, gdyż to $\mathrm{z}$ Niej Jezus przyjął ludzkie ciało. Zmartwychwstanie nie może zatem być sprowadzane zaledwie do osiągnięcia innej formy cielesności, ale należy je widzieć jako osiągnięcie świętości i sprawiedliwości Bożej - a takim najwyższym stopniem usprawiedliwienia była w wypadku Maryi uprzednia łaska niepokalanego poczęcia ${ }^{41}$.

\subsection{Niepokalanie Poczęta}

Po omówieniu trzech głównych prawd maryjnych, ogłoszonych przez Kościół starożytny jako formalne orzeczenia lub w sposób z nimi równoznaczny, pozostały nam jeszcze dwie, ogłoszone w czasach nowożytnych: niepokalane poczęcie oraz wniebowzięcie Najświętszej Maryi Panny. Oba dogmaty różnią się wyraźnie od wcześniej omawianych i mają ze sobą wiele cech wspólnych. Po pierwsze, nie można się bezpośrednio powołać na konkretne miejsce w Piśmie Świętym jako ich biblijną podstawę, jakkolwiek są one

${ }^{40}$ Por. S. Budzik, Maryja w tajemnicy Chrystusa i Kościoła, dz. cyt., s. 88-92.

${ }^{41}$ Por. B. Ferdek, Maryja w tajemnicy Zmartwychwstania Chrystusa, sm 14 (2012) nr 1-4, s. 21-34. 
wynikiem refleksji teologicznej opierającej się na przesłankach skrypturystycznych. Po drugie, okazją do ogłoszenia obu dogmatów nie były - jak w przypadku innych prawd dogmatycznych - błędy teologiczne. Przyczyną powstania definicji był raczej maryjny klimat przełomu xIx i xx wieku. Uroczyste ogłoszenie i potwierdzenie przez najwyższy autorytet Kościoła zakorzenionych w wierze ludu prawd odpowiadało głębokiej wewnętrznej potrzebie człowieka wierzącego, pragnącego wysławiać Boga za dzieła Jego łaski w Maryi. Obie prawdy zostały proklamowane późno, a ich akceptacja w Kościele poprzedzona była wielowiekową dyskusją teologiczną.

Inny jest również cel obu tych dogmatów. Nie mają one bezpośredniej funkcji chrystologicznej, tak jak dogmaty maryjne wczesnego Kościoła. Cechuje je natomiast swego rodzaju podwójna odpowiedniość: w stosunku do Chrystusa i w stosunku do wierzących. Dogmat niepokalanego poczęcia nawiązuje do wcielenia, zaś dogmat wniebowzięcia - do zmartwychwstania. W obu wypadkach chodzi o główne prawdy chrystologii. Istnieje jednak zasadnicza różnica. Wcielenie i zmartwychwstanie dokonują się Boską mocą samego Chrystusa, Maryja zaś jest przedmiotem Bożego działania i łaski.

Oba dogmaty maryjne nawiązują również do życia i powołania chrześcijan. Nauka o niepokalanym poczęciu koresponduje z teologią chrztu i podkreśla wolność Maryi od grzechu pierworodnego, zaś dogmat wniebowzięcia współbrzmi z nauką o powszechnym zmartwychwstaniu i życiu wiecznym.

\subsubsection{Rozwój wiedzy o niepokalanym poczęciu}

Nauka Kościoła, której człowiek winien jest posłuszeństwo wiary, moc obowiązującą czerpie z tego, że jej prawdy wywodzą się z objawienia Bożego, poświadczonego Pismem Świętym i Tradycją. Fakt ten wymaga każdorazowo udowodnienia. Droga od tekstu biblijnego do dogmatu ma specyficzną postać, która niekoniecznie identyczna jest $\mathrm{z}$ drogą logiki formalnej. Dopuszcza ona inne możliwości poznawania prawd objawionych i wczytywania się w nie, takie jak pobożność czy liturgię, zmysł wiary Kościoła czy duchową medytację. Również dopuszczona i wskazana jest droga teologicznej refleksji. Warunkiem $w$ tych wypadkach jest jedynie niesprzeczność z zasadami logiki. Nauka o niepokalanym poczęciu wiąże się ściśle z podstawowymi prawdami maryjnymi: macierzyństwa Bożego, trwałego dziewictwa oraz trwałej świętości i bezgrzeszności, jakkolwiek, o czym była już mowa, nie posiada bezpośredniego biblijnego uzasadnienia. 
Rozwój nauki i pogłębianie się wiary w niepokalane poczęcie Najświętszej Maryi Panny jest przykładem ewolucji dogmatu w oparciu o globalną intuicję wiary Ludu Bożego. Na Wschodzie czynnikiem sprzyjającym rozwojowi tej nauki była zwłaszcza liturgia. Wieki viı i viII to czas powstania i rozprzestrzeniania się uroczytości Poczęcia Maryi. To poczęcie jest określane jako święte i niepokalane. Jednym z najważniejszych świadków rozwoju nauki tym wydarzeniu jest Sofroniusz Jerozolimski (ok. 560-638). W usta anioła patriarcha Jerozolimy wkłada następujące słowa: „Przed Tobą było wielu z pewnością świętych ludzi. Nikt jednak nie był tak pełen łaski jak Ty, nikt bardziej od Ciebie błogosławiony; nikt nie został tak uświęcony, nikt tak wyniesiony; tylko Ty jedna zostałaś już wcześniej oczyszczona”. Świadectwa wiary Wschodu na ten temat znajdujemy ponadto u św. Andrzeja z Krety, św. Germana z Konstantynopola i św. Jana Damasceńskiego ${ }^{42}$.

W Kościele zachodnim istniało wiele czynników hamujących rozwój doktryny o niepokalanym poczęciu, np. kontrowersja pelagiańska. Pelagiusz (ok. 460 - ok. 435) przedstawiał świętość Maryi jako owoc jedynie ludzkiego wysiłku. Augustyn przypisywał natomiast osobistą świętość Maryi działaniu Bożemu i traktował ją jako przywilej związany z Bożym macierzyństwem. Innym elementem hamującym była augustyńska wizja grzechu pierworodnego jako dziedziczonego na podstawie faktu przekazywania życia: każdy zrodzony z ojca i matki musi temu prawu podlegać. Jedynie Chrystus, Syn Dziewicy, jest spod niego wyłączony. Niemały wpływ miały również teorie, które przesuwały powstanie duszy człowieka na bliższy lub dalszy okres od jego cielesnego poczęcia.

Podstawowa trudność, która skłaniała wybitnych teologów średniowiecznych do odrzucenia doktryny o niepokalanym poczęciu, była jednak innego rodzaju. Nauka ta wydawała się zagrażać podstawowej tezie chrystologicznej, głoszącej powszechność odkupienia dokonanego przez Chrystusa i w Chrystusie. Jak Maryja, która została poczęta i przyszła na świat według zwykłych prawideł ludzkiej kondycji, mogła nie podlegać choćby przez chwilę grzechowi, będącemu właściwością rodzaju ludzkiego? Jeśli była Ona człowiekiem (a przecież była), to nie mogła przyjść na świat wolna od zmazy pierworodnej. Problemem nie było przyjęcie uświęcenia Maryi, tak jak to sugeruje Pismo Święte o Janie Chrzcicielu, w łonie matki, zaraz po poczęciu, gdyż wtedy istniałby pewien czas, w którym Maryja byłaby objęta grzechem pierworodnym, a później odkupiona tak jak wszyscy ludzie.

${ }^{42}$ Por. F. Courth, Mariologia. Maryja, Matka Chrystusa, dz. cyt., s. 144. 
Wyjęcie choćby jednego człowieka spod prawa grzechu zdawało się zaprzeczać powszechnemu przekonaniu Pisma Świętego i Kościoła, że wszyscy są grzesznikami, a więc wszyscy potrzebują odkupienia. Przywilej niepokalanego poczęcia wyłączałby, jak sądzono, Maryję z dobrodziejstwa odkupienia i powszechnej konieczności zbawienia poprzez krzyż. Trudność tę rozwiązał pod koniec xIII wieku genialny szkocki filozof i teolog, Jan Duns, zauważając, że Maryja została zachowana od grzechu pierworodnego właśnie przez łaskę Odkupiciela. Jak wszyscy ludzie potrzebują Pośrednika, aby odpuszczono im wcześniej zaciągnięty grzech (dzieje się to w sakramencie chrztu), tak Maryja w jeszcze większym stopniu potrzebowała tegoż Pośrednika, aby Ją uchronił przed zaciągnięciem grzechu (w pierwszym momencie Jej istnienia).

Po śmierci Jana Dunsa Szkota wybuchła w Kościele ostra dyskusja teologiczna na ten temat. Przeciw doktrynie o niepokalanym poczęciu wypowiadali się zdecydowanie teologowie zakonu dominikańskiego, zwłaszcza odkąd św. Tomasz został kanonizowany (1323). Obrońcami zaś tej nauki stali się uczniowie św. Franciszka - stąd tezę tę zaczęto nazywać franciszkańską. W miarę upływu wieków coraz bardziej przeważała opinia uznająca niepokalane poczęcie za dogmat wiary.

Stopniowo włączał się do dyskusji także Urząd Nauczycielski Kościoła. Wolno wymienić tu papieża Sykstusa Iv, franciszkanina, który konstytucją Grave nimis zakazał zwolennikom doktryny niepokalanego poczęcia (immakuliści) i jej przeciwnikom (makuliści) wzajemnego oskarżania się o herezję. Z kolei w dokumencie o grzechu pierworodnym Sobór Trydencki orzekł, że „nie zamierza obejmować tym dekretem, w którym jest mowa o grzechu pierworodnym, świętej i niepokalanej Bożej Rodzicielki Maryi”“3. W 1617 roku Paweł v (1552-1621) zabronił publicznych wystąpień przeciw nauce o niepokalanym poczęciu, choć równocześnie nie odrzucał opinii przeciwnej. Papież Grzegorz Xv (1554-1623) nadał temu zakazowi ostrzejszą formę, zalecając dominikanom studia nad tą kwestią. Z kolei Aleksander viI (1599-1667) w bulli Sollicitudo Omnium Ecclesiarum z roku 1661 wyjaśniał, że „starożytna jest pobożna postawa chrześcijan” wobec niepokalanego poczęcia Dziewicy Maryi.

\footnotetext{
${ }^{43}$ BF VI 83 .
} 


\subsubsection{Treść dogmatyczna}

Dogmatycznego ogłoszenia prawdy wiary o niepokalanym poczęciu dokonał papież Pius Ix bullą Ineffabilis Deus w 1854 roku. Przedtem zwrócił się do biskupów świata z zapytaniem, z jaką czcią duchowieństwo i wierni odnoszą się do niepokalanego poczęcia Maryi i jakie jest zdanie biskupów na temat projektu ogłoszenia dogmatu. Zdecydowana większość opowiedziała się za definicją dogmatyczną, jakkolwiek biskupi z obszaru języka niemieckiego odnieśli się do niej negatywnie. Rezerwę wykazali również teologowie rzymscy. Trudno do końca zrozumieć tę postawę i tłumaczyć ją jedynie protestantyzacją Niemiec czy brakiem biblijnego uzasadnienia tej prawdy, niemniej można zaobserwować od xıx wieku coraz większą niechęć czy sceptycyzm teologii akademickiej wobec wszystkiego, co niezwykłe. Ponadto u teologów prawosławnych, co warto dodać, niechęć do tego dogmatu wynikała $\mathrm{z}$ faktu, że niepokalane poczęcie Maryi oddzielało Ją od reszty ludzi. Wydaje się, że te formy argumentacji ujawniają swoisty brak logiki i konsekwencji. Bo dlaczego zostało przyjęte dziewictwo Maryi, które jest nie mniej wyjątkowe i cudowne, a już niepokalane poczęcie miałoby zostać odrzucone?

Nawiązująca w licznych sformułowaniach do dokumentu papieża Aleksandra VII definicja niepokalanego poczęcia brzmi:

Na chwalę Świętej i niepodzielnej Trójcy, na cześć i uwielbienie Bożej Rodzicielki, dla wywyższenie wiary katolickiej i rozkrzewienia religii chrześcijańskiej, powagą Pana naszego Jezusa Chrystusa, świętych Apostołów Piotra i Pawła oraz Naszą ogłaszamy, orzekamy i określamy, że nauka, która utrzymuje, iż Najświętsza Maryja Panna od pierwszej chwili swego poczęcia - mocą szczególnej łaski i przywileju wszechmocnego Boga, mocą przewidzianych zasług Jezusa Chrystusa, Zbawiciela rodzaju ludzkiego - została zachowana nietkniętą od wszelkiej zmazy grzechu pierworodnego, jest prawdą przez Boga objawioną i dlatego wszyscy wierni powinni w nią wytrwale i bez wahania wierzyćc ${ }^{44}$.

W uzasadnieniu dogmatu bulla Ineffabilis Deus powołuje się przede wszystkim na tzw. fakt Kościoła, który powszechnie uznaje tajemnicę niepokalanego poczęcia Maryi i czyni ją przedmiotem czci wiernych, o czym świadczy szeroko rozpowszechnione w Kościele święto. Wyniki

44 BF VI 89. 
światowego „sondażu” przeprowadzonego wśród episkopatu, jak również liczne petycje biskupów wielu krajów, żądających dogmatyzacji niepokalanego poczęcia, dały papieżowi asumpt do stwierdzenia, że w dziedzinie tej panuje w Kościele jednomyślność. Jest to tzw. metoda dogmatyczna w odróżnieniu od metody historycznej. Metoda historyczna stara się wykazać istnienie jakiejś prawdy w Piśmie Świętym oraz przedstawić cały szereg świadectw nieprzerwanej tradycji od czasów apostolskich aż po dzień dzisiejszy.

Metoda dogmatyczna przyjmuje za punkt wyjścia aktualną wiarę całego Kościoła, zarówno nauczanie jego pasterzy, jak i powszechną zgodę wiernych. Taka zgoda całego Kościoła jest kryterium tego, że dana prawda wiary jest częścią objawienia Bożego. Chrystus bowiem obdarzył swój Kościół charyzmatem nieomylności.

\subsubsection{Wartość dogmatu}

Przypomnijmy jeszcze raz przełomowe odkrycie Jana Dunsa Szkota, gdyż to dzięki niemu mógł nastąpić dalszy rozwój i dogmatyzacja tej prawdy maryjnej. Ten franciszkański myśliciel rozróżnił odkupienie na zachowujące i wyzwalające, co pozwoliło na odkrycie harmonii między poczęciem bez grzechu a powszechnym odkupieniem. Tym samym na drodze do pełnej akceptacji tej prawdy w Kościele powszechnym mogła zostać usunięta zasadnicza przeszkoda, zgodnie z którą niepokalane poczęcie oznaczałoby wyjęcie Maryi spod prawa powszechnego odkupienia.

Jeżeli dogmaty maryjne pierwotnego Kościoła są w swojej istocie wypowiedziami na temat Chrystusa, a więc mają charakter przede wszystkim chrystologiczny, to współczesne dwa dogmaty maryjne mają charakter soteriologiczny. Nie stwierdzają, kim jest Chrystus, lecz orzekają o Jego dziele, o zbawieniu i odkupieniu, którego dokonał. Nauka o niepokalanym poczęciu Maryi umieszczona jest między dwoma zasadniczymi biegunami nauki chrześcijańskiej. Z jednej strony chodzi o zależność wszystkich ludzi od grzechu pierworodnego, a $\mathrm{z}$ drugiej o fakt powszechnego odkupienia przez Jezusa Chrystusa. Przywilej niepokalanego poczęcia można pojąć i wyjaśnić tylko wtedy, gdy rozumie się te dwa zasadnicze dogmaty.

Trzeba więc najpierw pytać o treść kościelnej nauki na temat grzechu pierworodnego. Współczesna teologia podejmuje próby nowego i pogłębionego spojrzenia na tę sprawę. Interesującym przykładem jest widzenie niepokalanego poczęcia jako zniesienia wszechwładztwa grzechu pierworodnego, 
co podkreśla prymat łaski nad grzechem. Pierwszym i fundamentalnym znakiem tego prymatu jest Jezus Chrystus ${ }^{45}$.

Nauka o grzechu pierworodnym polega na twierdzeniu, że człowiek przez fakt swojej przynależności do rodzaju ludzkiego, a więc w samym momencie stania się człowiekiem, wchodzi w związek $\mathrm{z}$ winą, mającą charakter społeczny, i ponosi jej konsekwencje, mimo że osobiście nie jest za ten stan odpowiedzialny. Przyjęcie natury ludzkiej jest jednoznaczne z obarczeniem grzechem pierworodnym. Dlatego człowiek ma faktyczny udział w „ogólnej tendencji” do grzechu i ją pogłębia przez osobistą winę. Grzech powiększa więc stale swój potencjał w świecie i nikt $\mathrm{z}$ ludzi nie jest w stanie tej sytuacji przezwyciężyć. Konieczne jest wyzwolenie pochodzące z zewnątrz, a więc odkupienie człowieka przez Boga.

Nauka Kościoła mówi, że przez odkupienie dokonane przez Chrystusa Bóg okazał wierność przymierzu zawartemu z człowiekiem, rozrywając i niwecząc - przez wcielenie, życie, mękę, śmierć i zmartwychwstanie swojego Syna - ludzkie uwikłanie się w grzech i winę. Człowiek jest więc zasadniczo uwolniony i ma możliwość dojść przez Jezusa Chrystusa do pełni życia z Bogiem w Trójcy Jedynym. Grzech nie jest zatem dla człowieka nieuniknionym fatum. Odkupieńcze działanie Boga nie wynika z jakiejkolwiek konieczności, lecz wypływa jedynie z Jego łaskawości wobec człowieka. Jesteśmy usprawiedliwieni bez żadnych naszych zasług. Usprawiedliwienie grzesznika (iustificatio impii) jest wyłącznie skutkiem Bożego miłosierdzia, objawionego i udzielonego przez Jezusa Chrystusa ${ }^{46}$.

Skoro Maryja jest w pełni człowiekiem, to również i Ona podlega powszechnemu prawu, które stawia każdego z nas wobec konieczności odkupienia. Niezależnie od wielkości powołania Maryi, Jej niezwykłej roli w historii zbawienia, jest Ona zasadniczo - jak to formułuje Konstytucja o Kościele - „W rodzie Adama złączona ze wszystkimi ludźmi, którzy mają dostąpić zbawienia" "47. Maryja potrzebuje więc odkupienia tak jak każdy człowiek. Została jednak odkupiona w sposób uprzedzający, tak że ani przez chwilę swej ludzkiej egzystencji nie pozostawała pod wpływem grzechu.

${ }^{45}$ Por. J. Bolewski, Misterium Mądrości. Traktat sofio-mariologiczny, Kraków 2012, s. 341352 (Myśl Teologiczna, 7o).

${ }^{46}$ Zob. A. A. Napiórkowski, Bogactwo łaski a nędza grzesznika. Zróżnicowany konsensus teologii katolickiej i luterańskiej o usprawiedliwianiu osiagnięty w dialogu ekumenicznym, Kraków 2011.

47 KK 53. 
Nie można odrywać daru pełnej świętości Maryi od tajemnicy Bożego macierzyństwa. Bóg jest świętością absolutną, Tym, do którego można się zbliżyć w świętości, a równocześnie Tym, który przekazuje świętość zbliżającym się do Niego. Maryja przez zrodzenie Chrystusa weszła w najściślejsze powiązanie z Bogiem, jakie tylko jest dla człowieka możliwe. Dlatego też została obdarzona doskonałą pełnią świętości od samego początku istnienia. Czy jednak nie byłoby wystarczające, gdyby Maryja została odkupiona tak jak inni ludzie, w konkretnym momencie swojego życia, np. podczas zwiastowania? Wydaje się, że nie. Grzech jest w swojej istocie sprzeniewierzeniem się człowieka Bogu i stawianiem własnej woli przed wolą Boga. Świętość człowieka polega zaś na całkowitej zgodności ludzkiej woli z wolą Boga. Grzech krępuje ludzką wolność, która potrzebna jest do przyjęcia daru Bożego. Tylko pod wpływem łaski może człowiek rozwinąć w pełni swą wolność, aby przyjąć z całym oddaniem dar Przenajświętszej Trójcy. Potrzeba więc było, aby Bóg przez swoją łaskę zerwał wszelki, nawet najmniejszy związek z grzechem u Matki swojego Syna. Dla Matki Odkupiciela odkupienie było od początku całkowite i pełne. Zachowanie od grzechu pierworodnego (a nie wyzwolenie od niego!) jest więc wewnętrzną konsekwencją wyboru Maryi na Matkę Jezusa.

$\mathrm{Z}$ tajemnicy uprzedzającego odkupienia Maryi płyną ważne wnioski dla chrześcijańskiej antropologii. Dogmat niepokalanego poczęcia ma znaczenie soteriologiczne również w odniesieniu do każdej osoby ludzkiej. Ukazuje ją mianowicie taką, jaką Bóg pragnie ją mieć według swojego początkowego planu. Wybrał nas bowiem, jak mówi List do Efezjan, „abyśmy byli święci i nieskalani przed Jego obliczem" (Ef 1, 4). Maryja cieszy się wolnością od jakiegokolwiek grzechu od samego początku swego istnienia nie tylko ze względu na swego Syna, lecz także ze względu na całą ludzkość powołaną do zbawienia.

Wolność od grzechu pierworodnego to aspekt negatywny prawdy o niepokalanym poczęciu Maryi. W sensie pozytywnym dogmat ten definiuje pełnię świętości i łaski u Maryi oraz całkowite przeniknięcie Duchem Świętym. Oznacza to, że Maryja cieszy się od pierwszego momentu swojego istnienia tą wspólnotą życia z Bogiem, której każdy chrześcijanin dostępuje w chwili przyjęcia chrztu.

Niepokalane poczęcie ukazuje faktyczną zbieżność pomiędzy stworzeniem i odkupieniem. Pełne odkupienie od pierwszego momentu ludzkiej egzystencji oznacza historyczne zrośnięcie się rozdartej rzeczywistości świata i człowieka. Maryja jest pierwszą przedstawicielką nowej 
ludzkości, będącej odtworzeniem ludzkości spod znaku stwórczego planu Boga. Staje się w ten sposób znakiem eschatologicznym dla przyszłych pokoleń. Dogmat niepokalanego poczęcia ugruntowuje więc niezwykłą rolę Maryi w społeczności Kościoła. W Maryi - jako nowej Ewie - dokonała się realizacja absolutnego prymatu łaski nad bezgrzesznością Ludu Bożego. Moc łaski nabrała w Niej absolutnej pewności. W tajemnicy niepokalanego poczęcia objawiła się Maryja jako nowa Ewa i archetyp Kościoła, poświadczając nade wszystko wyższość i pełnię łaski, a nie ludzką niezależność, samodzielność czy osiąganie świętości ${ }^{48}$.

\subsection{Wniebowzięta}

Z dogmatem niepokalanego poczęcia Maryi związana jest ściśle nauka o Jej wniebowzięciu. Doskonałemu odkupieniu na początku ziemskiego istnienia Maryi odpowiada pełnia zbawienia i chwały u kresu Jej życia. Wiara we wniebowzięcie Matki Bożej nawiązuje do tajemnicy wniebowstąpienia Chrystusa. Już w samej nazwie występuje jednak zasadnicza różnica. Chrystus wstępuje (ascensio) do chwały niebieskiej mocą swojego Bóstwa, Maryja zaś zostaje wzięta (assumptio) do tego stanu, czyli zawdzięcza swoje wywyższenie łaskawości Boga. Wniebowzięcie nie realizuje się Jej własną mocą, ale dzięki absolutnej łaskawości Boga.

Prawda o wniebowzięciu Maryi słusznie koncentruje uwagę na jeszcze bardziej fundamentalnej i powszechniejszej prawdzie chrześcijańskiego objawienia, a mianowicie na eschatologii; podkreśla pielgrzymowanie Ludu Bożego do jego pełni, której doświadczy on w momencie paruzji. $\mathrm{W}$ tym świetle mariologia wzmacnia eschatologię. Chrześcijanie bowiem nie są ludźmi bez przyszłości, lecz za Matką swojego Pana podążają do królestwa Bożego. Nie bez powodu Paweł Apostoł wyzna:

Chlubimy się nadzieją chwały Bożej. Ale nie tylko to, lecz chlubimy się także z ucisków, wiedząc, że ucisk wyrabia wytrwałość, a wytrwałość - wypróbowaną cnotę, wypróbowana cnota zaś - nadzieję. A nadzieja zawieść nie może, ponieważ miłość Boża rozlana jest w sercach naszych przez Ducha Świętego, który został nam dany (Rz 5, 1-5).

${ }^{48}$ Por. S. Budzik, Maryja w tajemnicy Chrystusa i Kościoła, dz. cyt., s. 92-104. 
Również w dokumentach soborowych znajdujemy inspirujący tekst, który ukazuje Bożą Rodzicielkę jako obraz eschatologicznej nadziei. Ojcowie soborowi zwracają się z zachętą do wszystkich chrześcijan, aby błagali

wytrwale Matkę Boga i Matkę ludzi, aby Ta, która swymi modlitwami wspierała początki Kościoła, także i teraz w niebie, wywyższona ponad wszystkich świętych i aniołów, w komunii wszystkich świętych wstawiała się u swego Syna, dopóki wszystkie rodziny narodów, zarówno tych, które noszą zaszczytne imię chrześcijan, jak i tych, co nie znają jeszcze swego Zbawiciela, nie zgromadzą się szczęśliwie w pokoju i zgodzie w jeden Lud Boży na chwałę Przenajświętszej i niepodzielnej Trójcy ${ }^{49}$.

\subsubsection{Rozwój rozumienia wiary}

Jeśli chodzi o prawdę wiary, jaką jest wniebowzięcie Najświętszej Maryi Panny, to nie posiadamy wyraźnych źródeł ani w Piśmie Świętym, ani powstałych w pierwszych wiekach patrystyki. Dopiero w IV wieku możemy wskazać Efrema Syryjczyka i Grzegorza z Nazjanzu. Nie brak jednak świadectw wcześniejszych, zawierających ideę wniebowzięcia w mniej lub bardziej wyraźnej formie. Przytacza się często słowa Epifaniusza z Jerozolimy, który stawiając pytanie o koniec ziemskiego życia Maryi, przyjmuje, że musiało ono mieć zakończenie godne Matki Boga. Temat wniebowzięcia pojawił się stosunkowo wcześnie w licznych apokryfach, zwanych Transitus Mariae. W vi wieku rozpowszechniło się w liturgii święto Zaśnięcia Maryi. Około roku 600 pod datą 15 sierpnia obchodzone było w Konstantynopolu. Wkrótce rozprzestrzeniło się również na Kościół zachodni, o czym świadczą księgi liturgiczne z Francji, Anglii i Hiszpanii. Konkretny wyraz prawda o wniebowzięciu znajduje dopiero w nauce greckich ojców Kościoła, takich jak św. Jan Damasceński, św. German, patriarcha Konstantynopola, czy św. Andrzej z Krety w pierwszej połowie viII wieku.

Ogłoszenie dogmatu niepokalanego poczęcia w roku 1854 przyczyniło się do wzmożonego zainteresowania zagadnieniami mariologicznymi i doprowadziło w końcu do dogmatyzacji wniebowzięcia. Poprzedził ją trwający dziesiątki lat tzw. ruch asumpcjonistyczny, którego wyrazem były m.in. ustawiczne petycje, zarówno indywidualne, jak i zbiorowe, kierowane do Stolicy Apostolskiej z prośbą o proklamację dogmatu o wniebowzięciu.

\footnotetext{
49 KK 69.
} 
Starania o ogłoszenie tego dogmatu podjęto na Soborze Watykańskim I. Prawie dwustu ojców Soboru domagało się takiej definicji. Nie doszło jednak do dyskusji z powodu przerwania Soboru przez wojnę francusko-pruską (1870-1871).

Podobnie jak papież Pius Ix przed ogłoszeniem dogmatu o niepokalanym poczęciu, tak również Pius XII (1876-1958) zwrócił się przed podjęciem decyzji do biskupów świata $\mathrm{z}$ zapytaniem o powszechność wiary w tajemnicę wniebowzięcia Maryi oraz o potrzebę proklamacji dogmatu. Był to swego rodzaju sobór korespondencyjny, w którym wzięła udział większość biskupów całego świata. Niemal wszyscy zajęli pozytywne stanowisko odnośnie do potrzeby zdefiniowania dogmatu wniebowzięcia.

Konstytucja apostolska Munificentissimus Deus, ogłaszająca ex cathedra prawdę o wniebowzięciu Maryi jako obowiązujący dogmat wiary, opublikowana została 1 listopada 1950 roku. W obszernym historycznym wstępie dokument ukazuje, jak Kościół stopniowo uświadamiał sobie pełnię prawdy o wniebowzięciu. Dokument podkreśla, że najważniejszym argumentem jest argument biblijny. Papież nie powołuje się wszelako na żaden konkretny tekst, ale udowadnia, odwołując się do całości Nowego Testamentu. Pismo Święte ukazuje mianowicie Maryję całkowicie zjednoczoną z Jezusem i dzielącą Jego los. Z przekazu Ewangelii wnioskować można o niezwykłej wspólnocie losów Maryi i Jezusa od samego początku Jego istnienia, nie tylko w okresie dzieciństwa i życia ukrytego, lecz także - jak sugerują to teksty Janowe - podczas Jego publicznej działalności. Z tego względu wydaje się prawie niemożliwe, mówi konstytucja, aby Maryja po swoim ziemskim życiu mogła być oddzielona w jakikolwiek sposób od swego Syna ${ }^{50}$.

Dokument papieski powołuje się na tekst Protoewangelii i nawiązuje do tradycji patrystycznej, która widziała w Maryi nową Ewę, poddaną nowemu Adamowi i z Nim złączoną. Maryja jest z Chrystusem złączona również $w$ walce ze złem, która prowadzi do zwycięstwa nad grzechem i śmiercią. Konstytucja powołuje się także na teologię św. Pawła, który zwłaszcza w Listach do Rzymian i do Koryntian - łączył zwycięstwo nad grzechem ze zwycięstwem nad śmiercią.

Wniebowzięcie jest dla papieża Piusa XII ukoronowaniem przywilejów, którymi Bóg obdarzył Matkę swojego Syna. Została Ona „zachowana wolną od zepsucia grobu, aby na podobieństwo Syna, po zwycięstwie nad śmiercią, z duszą i ciałem wstać wyniesiona do najwyższej chwaty nieba i nam jaśnieć

${ }^{50}$ Por. S. Budzik, Maryja w tajemnicy Chrystusa i Kościoła, dz. cyt., s. 105-107. 
jako Królowa po prawicy tegoż Syna, nieśmiertelnego Króla wieków"51. Najważniejszy fragment definicji głosi:

Dlatego po wielokrotnym zanoszeniu modlitw do Boga i wzywaniu światła Ducha Prawdy, na chwałę Wszechmogącego Boga, który okazał swą szczególną życzliwość Maryi Dziewicy, na chwałę Jego Syna, nieśmiertelnego Króla wieków, zwycięzcy grzechu i śmierci - dla powiększenia chwały Jego Czcigodnej Matki oraz ku weselu i radości całego Kościoła, powagą Pana naszego Jezusa Chrystusa, świętych Apostołów Piotra i Pawła i Naszą, ogłaszamy, orzekamy i określamy jako dogmat objawiony przez Boga, że Niepokalana Matka Boga, Maryja zawsze Dziewica, po zakończeniu ziemskiego życia z duszą i ciałem została wzięta do chwały niebieskiej ${ }^{52}$.

Istotne jest zwłaszcza ostatnie zdanie definicji, nawiązujące do najważniejszych dogmatów maryjnych: niepokalanego poczęcia, Bożego macierzyństwa, dziewictwa; podkreśla ono, że wniebowzięcie jest dopełnieniem i ukoronowaniem wszystkich innych przywilejów Matki Chrystusa. Konstytucja Munificentissimus Deus nie wypowiada się w kwestii śmierci Maryi. Mówi jedynie o „zakończeniu Jej ziemskiego życia”, aby zostawić otwartym problem śmierci Maryi, żywo dyskutowany w owym czasie przez teologów. Dokument nie rozstrzyga tego sporu, lecz podkreślając tajemnicę uwielbienia Maryi, daje do zrozumienia, że problem śmierci jest raczej drugorzędny. Słowa „z duszą i ciałem” podkreślają, że Maryja została uwielbiona w pełni swojego człowieczeństwa, zarówno w jego aspekcie duchowym, jak i cielesnym. Wzięcie, assumptio, jest tym samym terminem, za pomocą którego Pismo Święte Starego Testamentu wyraża prawdę o przejściu człowieka do życia wiecznego.

Cel dogmatyzacji jest doksologiczny - chodzi tu o oddanie chwały Bogu (na co wskazują terminy: chwała, wesele, radość) za dzieło zbawienia w pełni objawione i zrealizowane w osobie Maryi. Konstytucja nie zaznacza, że chodzi tu o przywilej dotyczący jedynie Maryi, jak było to w wypadku niepokalanego poczęcia. Otwiera to szerokie pole spekulacjom teologicznym na temat terminu i sposobu uwielbienia innych ludzi, zwłaszcza wobec całkowitej nieadekwatności czasu, jaki odmierza bieg życia ludzkiego, i wieczności, której próg człowiek przekracza w chwili śmierci.

\footnotetext{
51 BF VI 103.

52 BF VI 105.
} 


\subsubsection{Dogmat}

Teologia dogmatu o wniebowzięciu Najświętszej Maryi Panny, wyrażająca łaskę obdarowania Maryi pełnią zbawienia, dotyka swoją problematyką ważnych tematów teologicznych, łączących się z eschatologią i antropologią. Podstawą nauki o wniebowzięciu jest nauka o Bożym macierzyństwie i trwałym dziewictwie Najświętszej Maryi Panny. Jak niepokalane poczęcie jest zapowiedzią tych podstawowych prawd maryjnych, tak wniebowzięcie jest ich eschatologicznym dopełnieniem. Dogmat ten ukazuje ostateczne konsekwencje wyboru dokonanego przez łaskę. W tym znaczeniu definicja wniebowzięcia jest konsekwencją dogmatu $\mathrm{z}$ roku 1854 . W nauce o eschatologicznym uwielbieniu Maryi zawiera się jednak nowy element w stosunku do prawdy o niepokalanym poczęciu. Dogmat o uprzednim odkupieniu Maryi z grzechu pierworodnego kierował spojrzenie na Sprawcę tego niebiańskiego przywileju, a więc był elementem teologii odkupienia i łaski. Nauka o wniebowzięciu bierze pod uwagę również całe życie Matki Chrystusa, która w czasie ziemskiej wędrówki w pełni odpowiedziała na łaskawe wybranie przez Boga. Na dar szczególnego wybrania udzieliła doskonałej odpowiedzi wiary. Z pełni łaski, której u Maryi odpowiada pełnia wiary, wynika pełnia eschatologicznego uwielbienia.

Dogmatu wniebowzięcia rodzi konsekwencje dla chrześcijańskiej antropologii. Ogłoszenie dogmatu uwielbienia Maryi, które obejmuje pełnię Jej człowieczeństwa, a więc duszę i ciało, jest przypomnieniem światu wartości ludzkiego ciała. Jest rzeczą zastanawiającą, jak bardzo Kościół podkreśla w swojej nauce rolę ciała ludzkiego. Chrześcijańska nauka przypisuje mu bowiem nie tylko przejściowe, lecz także trwałe znaczenie, wychodzące poza ramy jego ziemskiej egzystencji. To nie wyłącznie dusza, ale cała osoba ludzka jest przedmiotem troski Kościoła. Należy się wystrzegać dualizmu, jaki sugeruje potoczne używanie i rozumienie pojęć „dusza” i „ciało”. Człowiek nie składa się z dwóch części, lecz jest jednością. Osoba nie posiada duszy, tak jak posiada wartości materialne, lecz jest jednocześnie duszą i ciałem ${ }^{53}$. Katechizm uczy:

Człowiek, stanowiący jedność ciała i duszy, skupia w sobie dzięki swej cielesnej naturze elementy świata materialnego, tak że przez niego dosięgają one swego szczytu i wznoszą głos w dobrowolnym chwaleniu Stwórcy. Nie wolno

53 Por. L.-J. Suenens, Kim jest Ona? Synteza Mariologii [brak inf. o tłum.], Warszawa 1988, s. 87 . 
więc człowiekowi gardzić życiem ciała, lecz przeciwnie, powinien on uważać ciało za swoje jako przez Boga stworzone i mające być wskrzeszone w dniu ostatecznym, za dobre i godne szacunku. Jedność ciała i duszy jest tak głęboka, że można uważać duszę za „formę” ciała; oznacza to, że dzięki duszy duchowej ciało utworzone $\mathrm{z}$ materii jest ciałem żywym i ludzkim; duch i materia w człowieku nie są dwiema połączonymi naturami, ale ich zjednoczenie tworzy jedną naturę $e^{54}$.

Dogmat wniebowzięcia jest w swoim eschatologicznym wymiarze profetyczną zapowiedzią naszego przyszłego zmartwychwstania i uwielbienia. I w naszym wypadku ma się to dokonać w pełni człowieczeństwa, a więc zarówno w aspekcie duchowym, jak i cielesnym. Wniebowzięcie uchyla więc niejako rąbka tajemnicy nieba, czyli stanu wiecznego szczęścia zbawionych. Chrześcijańska wizja królestwa Bożego nie przedstawia zbawionych jako nierealnych i pozbawionych radości duchów, niemających nic wspólnego z tym, co przeżywamy na ziemi. Takie rozumienie nieba prowadzi często do zarzutu, że jest ono miejscem zgoła nudnym i nieciekawym. Chrześcijańskie niebo nie jest osamotnieniem i negacją tego, co się poznało i co się kocha. Chwały uwielbienia dostępuje cały człowiek, z pełnią swoich doświadczeń i relacji, z całym swoim światem wewnętrznym i z własnym widzeniem świata zewnętrznego ${ }^{55}$.

\subsubsection{Czy Maryja doznała fizycznej śmierci?}

Jak rozumieć stwierdzenie, że Maryja została wzięta do nieba? Stoimy przed trudnym pytaniem, na które współczesna mariologia i eschatologia wciąż nie znajdują pełnej odpowiedzi. Tradycja wschodnia, nie roztrząsając tej kwestii, stwierdzi krótko, że Maryja „zasnęła” (dormitio Mariae). Jak zauważa Grigorios Larentzakis, przedstawiciel greckiego prawosławia, nauka o Maryi w prawosławnym Kościele jest o wiele bardziej zakorzeniona w życiu liturgicznym niż w orzeczeniach dogmatycznych. Troparion święta Zaśnięcia Maryi wyznaje: „W zrodzeniu zachowałaś dziewictwo, w zaśnięciu nie opuściłaś świata, Boża Rodzicielko. Przeszłaś do życia, Ty, która jesteś Matką Życia, aby poprzez Twoje wstawiennictwo wybawiać nasze dusze od śmierci”. Greckie wyrażenie metestis - „przeszłaś” - wskazuje na przekonanie, że Maryja pozostała przy życiu, aby mogła dalej działać jako

54 KKK 364-365.

55 Por. S. Budzik, Maryja w tajemnicy Chrystusa i Kościoła, dz. cyt., s. 104-112. 
Opiekunka wierzących. Oczywiście termin metastasis oznacza przejście ze śmierci do życia ${ }^{56}$. I na tym zasadniczo kończą się wyjaśnienia teologii prawosławnej, gdy idzie o tajemnicę wniebowzięcia.

Na temat śmierci Maryi Kościół wschodni milczy, natomiast w zachodnim mamy tylko próby rozwiązań ze strony teologów - Magisterium nie podejmuje tego tematu. Zwolennicy nauki głoszącej, że Maryja nie umarła, tzw. immortaliści, podkreślają, że śmierć jest następstwem grzechu. Maryja więc, jako Niepokalanie Poczęta, ich zdaniem nie podlega prawu śmierci. Twierdzą, że plan Boży powinien się zrealizować w pełni przynajmniej w jednym człowieku, w Maryi, która dała życie Słowu Przedwiecznemu. W tym duchu starają się też interpretować wypowiedzi bulli dogmatycznej papieża Piusa xII, który nie mówi o zmartwychwstaniu Maryi, ale o pełnym Jej uwielbieniu, zarówno w aspekcie somatycznym, jak i duchowym.

Natomiast tzw. mortaliści są zdania, że Maryja przeszła przez bramę śmierci. Uważają, że powszechność śmierci, wynikająca z samej natury ludzkiej i jej struktury, poświadczona przez Pismo Święte, obejmuje również Maryję. Śmierć potwierdza więc prawdę Jej ludzkiej egzystencji. Ważnym argumentem jest tutaj fakt śmierci Jezusa. Maryja, jako współuczestniczka cierpień Chrystusowych, podzieliła z Nim ten los. Uwolnienie Maryi od grzechu pierworodnego nie likwiduje cierpień fizycznych ani śmierci. Przemawia za tym również tradycja Kościoła, zwłaszcza wschodniego, który mówi o zaśnięciu, co sugeruje łagodną śmierć, bez konsekwencji, jaką jest rozkład ciała. W tym sensie wypowiedział się również papież Paweł vi w homilii z okazji święta Wniebowzięcia.

Spójrzmy na zagadnienie śmierci Maryi w świetle współczesnego nauczania teologii katolickiej. Pytanie brzmi: czy Maryja faktycznie umarła, aby zostać potem uwielbioną, czy też otrzymała dar nieśmiertelności? Z jednej strony mamy prawdę wiary, że śmierć jest karą za grzechy, a z drugiej twierdzenie, że Maryja była zachowana od grzechu pierworodnego. A zatem skoro była zachowana od zmazy pierworodnej, to nie umarła. Jednakże rodzi się kolejne pytanie: dlaczego miałaby zostać wyjęta z powszechnego prawa śmierci? Jeżeli Chrystus poniósł śmierć męczeńską, to czy Maryja zespolona ze swoim Synem nie powinna była także przeżyć boleśnie swojej

${ }^{56}$ Por. G. Larentzakis, Die orthodoxe Kirche. Ihr Leben und ihr Glaube, Graz-Wien-Köln 2000, s. 110-114. 
śmierci, aby wraz z Nim dostąpić chwały zmartwychwstania? - zapytuje boliwijski teolog, Nestor Giraldo Ramirez ${ }^{57}$.

Nasuwa się następująca próba odpowiedzi: Maryja faktycznie umarła, ale nie z powodu zmazy pierworodnej, gdyż mocą przywileju niepokalanego poczęcia została uprzednio zachowana od skutków grzechu pierworodnego. Jeżeli Jej szczególnym przywilejem jest uprzedzenie końcowego zmartwychwstania, które ma się dokonać w momencie paruzji, to czyż nie można konkludować, że także Ona uległa biologicznej śmierci - jednak nie z powodu grzechu, lecz dlatego, że w pełni dzieliła ludzki los swojego Syna, który stał się całkowicie też Jej doświadczeniem? ${ }^{58}$

Pozostańmy przy rozważaniach o wniebowzięciu w obrębie eschatologii. Po pytaniu, czy Maryja rzeczywiście umarła (i twierdzącej odpowiedzi), wypada przejść do problemu cielesności zmartwychwstania. Jeśli Maryja faktycznie umarła, to co stało się z Jej ciałem? Z pomocą mogą tu przyjść propozycje niektórych teologów. Jednakże, aby nie popaść w zawiłą dyskusję, odwołamy się do tekstu magisterialnego, jakim jest list Kongregacji Nauki Wiary z dnia 17 maja 1979 roku. Dokument ten, zatytułowany $W$ sprawie niektórych zagadnień związanych z eschatologia, podtrzymuje tradycyjne stanowisko na temat dwóch etapów po śmierci z okresem pośrednim. Oznacza to, że „Kościół przyjmuje istnienie i życie po śmierci elementu duchowego, obdarzonego świadomością i wolą, w taki sposób, że «ja ludzkie» istnieje nadal, chociaż w tym czasie brakuje dopełnienia

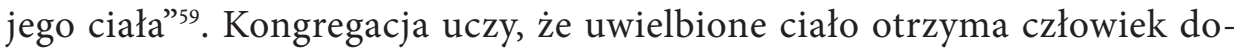
piero w momencie paruzji, co będzie „odrębne i późniejsze w stosunku do sytuacji ludzi zaraz po śmierci”" ${ }^{60}$. Watykańska dykasteria podejmuje również kwestię cielesności Matki Bożej. W przywoływanym dokumencie czytamy: „Kościół w swojej nauce o losie człowieka po śmierci wyklucza wszelkie tłumaczenie, które pozbawiałoby sensu wniebowzięcie Dziewicy Maryi: uwielbienie ciała Dziewicy jest uprzednie w stosunku do uwielbienia, jakie jest przeznaczone dla wszystkich zbawionych" ${ }^{\text {. }}$.

57 Por. N. G. Ramirez, Chwalebne wniebowzięcie Maryi, „Communio. Międzynarodowy Przegląd Teologiczny" 2000 nr 6 (120), s. 122-123.

${ }^{58}$ Por. tamże, s. 123.

${ }^{59}$ Kongregacja Nauki Wiary, List do Biskupów o niektórych zagadnieniach dotyczacych eschatologii, 3 [w:] W trosce o petnię wiary. Dokumenty Kongregacji Nauki Wiary 1966-1994, dz. cyt., s. 130. Por. AAS 71 (1979), s. 939-943.

${ }^{60}$ Tamże, 3, s. 131.

${ }^{61}$ Tamże, 6, s, 131. 
Kierując się względami duszpasterskimi, Kongregacja utrzymuje tzw. eschatologię tradycyjną, czyli naucza, że zmartwychwstanie osoby nastąpi w momencie paruzji. Wówczas ludzie otrzymają dopełnienie do swojego jestestwa, którym będą ich uwielbione ciała. Natomiast po śmierci aż do zmartwychwstania człowiek trwa jako pewien świadomy element, który możemy oznaczyć słowem „dusza”, gdyż jest ono terminem dobrze znanym zarówno w Piśmie Świętym, jak i Tradycji, chociaż przybiera różne znaczenia. Inaczej jednak sprawa ma się z Maryją. Oddajmy głos Donalowi Flanaganowi, który tak podsumowuje prawdę o uwielbionej cielesności Matki Pana:

Nauka Kościoła o wniebowzięciu - zgodnie z ogólnie przyjętym jej rozumieniem - podkreśla, jak się wydaje, tezę o stanie pośrednim oraz odkłada zmartwychwstanie ciał do dnia ostatecznego. Człowiek, który osiągnął uczestnictwo $\mathrm{w}$ chwale przed dniem ostatecznym, ukazuje się jako dusza odłączona (anima separata), podczas gdy Maryja - jako w pełni i całkowicie odkupiony człowiek [...]. Tradycja widzi Maryję uwielbioną, w społeczności świętych, jako pierwszą z odkupionych, na czele aniołów i świętych oraz jako typ Kościoła [...]. Takie zrozumienie Wniebowzięcia bardzo wyraźnie podkreśla jego znaczenie eschatologiczne; pozwala też ukazać jego definicję dogmatyczną jako środek umożliwiający nowe zrozumienie relacji istniejących między „tą" $i$ „tamtą" stroną ${ }^{62}$.

\subsubsection{Przywilej tylko Maryi?}

Wśród współczesnych teologów coraz częściej podnoszą się głosy, aby dogmatu wniebowzięcia nie zawężać jedynie do osoby Najświętszej Maryi Panny, ale rozciągnąć go na wszystkich wierzących. W jakim sensie to rozumieć?

W treści tego dogmatu Karl Rahner widział „coś, co jest zrozumiałe samo przez się dla wszystkich chrześcijan”. Niemiecki teolog uważał, że „to samo, co wiara mówi o Maryi, stanowi przedmiot nadziei wszystkich. Wniebowzięcie jest jedynie dopełnieniem zbawczego dzieła Boga i Jego łaski, którego my wszyscy oczekujemy"63. Dogmat ten należy zatem interpretować

${ }^{62}$ D. Flanagan, Eschatologia a wniebowzięcie, tłum. z ang. S. Napiórkowski, „Concilium. Międzynarodowy Przegląd Teologiczny” 1969 nr 1, s. 83-84. Cytat za: N. G. Ramirez, Chwalebne wniebowzięcie Maryi, dz. cyt., s. 124.

${ }^{63}$ K. Rahner, Grundkurs des Glaubens, Freiburg-Basel-Wien 1976, s. 375 [tłum. własne autora]. 
szerzej i ujmować go jako coś więcej niż wyłącznie przywilej Najświętszej Maryi Panny. Jeśli zmartwychwstanie dokonuje się w momencie śmierci, to - jak zauważa Gisbert Greshake - ogłoszenie dogmatu w 1950 roku nie było oficjalnym potwierdzeniem szczególnego przywileju Maryi, ale nowym sformułowaniem powszechnej tezy soteriologicznej ${ }^{64}$. Według tej tezy zmartwychwstanie Jezusa nie jest odizolowanym wydarzeniem, gdyż On sam jest pierwszym zmartwychwstałym, za którym podąża wspólnota wierzących w Niego. W dogmacie wniebowzięcia Magisterium orzekło, że także i Kościół jako wspólnota ludzi wiary ma niezbywalny udział w zmartwychwstaniu swojego Pana ${ }^{65}$.

Ta stosunkowo szeroka interpretacja dogmatu wniebowzięcia Najświętszej Maryi Panny pozwala określić znaczenie tej prawdy dla wszystkich chrześcijan w następujący sposób:

1. zbawienie ma charakter konkretny i personalny, dotyczy osoby ludzkiej;

2. mimo swoich ograniczeń człowiek może osiągnąć zbawienie wskutek niezależnego daru łaski;

3. cały człowiek ma przed sobą nadzieję i przyszłość, której celem i szczytem jest Bóg;

4. odkupienie i zbawienie odnoszą się również do ludzkiego ciała, które w jedności z duszą jest nakierowane ku Bogu. To, co rozpoczęło się w dziewiczym macierzyństwie Maryi, w Jej świętości i bezgrzeszności, dopełniło się w Jej wniebowzięciu - to także odnosi się do każdego chrześcijanina;

5. wywyższenie Maryi zawiera w sobie ideę Jej nieustannego wstawiennictwa za pielgrzymującym Ludem Bożym ${ }^{66}$.

Z tej wyjątkowości Bożej Rodzicielki, której ziemskie życie przemieniło się za sprawą zmartwychwstania Jej cielesności i pełnej radości przebywania w chwale nieba, wynika Jej zdolność i moc wspierania wierzących w Chrystusa, którzy wciąż są w drodze ku temu. Naturalnie, to przynoszące wyzwolenie pielgrzymowanie dokonuje się dzięki wierze wyznawców Chrystusa jako wspólnoty Ludu Bożego w tajemnicy odkupienia, będącego wielkim darem Trójcy Przenajświętszej. A ponieważ ten pielgrzymujący Kościół poddawany jest nieustannie próbom i wyzwaniom, to absolutnie potrzebuje pomocy i wsparcia od zmartwychwstałego Pana. Wśród

\footnotetext{
${ }^{64}$ Por. G. Greshake, Maria - Ecclesia. Perspektiven einer marianisch grundierten Theologie und Kirchenpraxis, Regensburg 2014, s. 284-300.

${ }^{65}$ Por. F. Courth, Mariologia. Maryja, Matka Chrystusa, dz. cyt., s. 183.

${ }^{66}$ Por. tamże, s. 184-185.
} 
wiernych już od początków istniało przekonanie, że właśnie Maryja przebywająca $w$ chwale nieba oręduje za wierzącymi w Chrystusa. Ten sensus fidelium - o którym uczy Sobór Watykański iI w konstytucjach Lumen gentium oraz Dei verbum ${ }^{67}$ - pochodzi przecież od Ducha Świętego i jest właściwy całej społeczności eklezjalnej. Paweł Apostoł uczy: „Zostaliście obmyci, uświęceni i usprawiedliwieni w imię Pana naszego Jezusa Chrystusa i przez Ducha Boga naszego" (1 Kor 6, 11). Owo wyczucie wierzących znalazło swoje potwierdzenie w modlitwach do Maryi jako Pośredniczki. Przykładem może być tu tekst Pod Twoją obronę czy Kanon rzymski, w którym Maryja jest wzywana jako pierwsza pośród świętych. Przyzywanie Maryi jako Pośredniczki jest dość wymowne w tym starożytnym pomniku chrześcijańskiej pobożności. Tekst Pod Twoją obronę ukazuje Maryję jako świętą Bożą Rodzicielkę jednającą ludzi ze swoim Synem ${ }^{68}$.

W soborowej Konstytucji o Kościele Lumen gentium czytamy:

Wzięta do nieba, nie zaprzestała pełnić tej zbawczej roli, lecz poprzez swoje wielorakie wstawiennictwo ustawicznie wyjednuje nam dary wiecznego zbawienia. Dzięki macierzyńskiej miłości opiekuje się braćmi swego Syna, pielgrzymującymi jeszcze i narażonymi na niebezpieczeństwa i trudy, dopóki nie zostaną doprowadzeni do szczęśliwej ojczyzny ${ }^{69}$.

${ }^{67}$ Por. KK 12; Sobór Watykański II, Konstytucja dogmatyczna o Objawieniu Bożym Dei verbum, 8.

${ }^{68}$ Por. A. A. Napiórkowski, Wniebowzięta umacnia wiarę w eschatyczne powołanie Kościoła, [w:] Jasnogórska Szkoła Wiary. Ogólnopolskie Sympozjum Mariologiczno-Maryjne, Jasna Góra, 10 kwietnia 2013, red. Z. S. Jabłoński, Częstochowa 2013, s. 83-98.

${ }^{69} \mathrm{KK} 62$. 


\section{Jedność Maryi z Duchem Świętym}

Jedność Matki Jezusa z Duchem Świętym jest podstawą Jej istnienia i działania w integralnie rozumianym dziele zbawczym. Niniejszy rozdział dotyczy trzech aspektów ścisłego zjednoczenia Maryi z trzecią Osobą Boską, mianowicie: przesłanek biblijnych, teologicznych podstaw tej jedności i form tego zjednoczenia.

Część pierwsza tego rozdziału to zatem prezentacja związków Maryi z Duchem Świętym w biblijnym ujęciu, ukazanie poczęcia Syna Bożego przez Maryję w Duchu Świętym oraz charyzmatów służebnych Maryi i Jej modlitwy. Kolejna część ma ukazać niepokalane poczęcie, wcielenie Syna Bożego, jedność Maryi z trzecią Osobą Boską w trakcie ziemskiego życia Jezusa, Jej obecność pod krzyżem w chwili śmierci Jezusa oraz zesłanie Ducha Świętego. Natomiast w trzeciej części zajmiemy się formami i sposobami zjednoczenia Matki naszego Pana z Duchem Świętym. Omówione tu zostaną takie relacje, jak: synergia, miejsce, obraz i ikona oraz objawienie i przejrzystość ${ }^{1}$.

\subsection{Biblijne przesłanki: Maryja i Duch Święty}

$\mathrm{Na}$ ukazane w poprzednich rozdziałach, zwłaszcza nowotestamentalne, świadectwa o Maryi z Nazaretu można i należy spojrzeć także z perspektywy

1 Por. G. Bartosik, Mediatrix in Spiritu Mediatore. Pośrednictwo Najświętszej Maryi Panny jako uczestnictwo w pośredniczacej funkcji Ducha Świętego w świetle teologii współczesnej, Niepokalanów 2006, s. 325-328 (Biblioteka Mariologiczna). 
pneumatologicznej. Nie chodzi tu tylko o wydobycie z Pisma Świętego wszystkich tekstów, które wiążą Matkę naszego Pana z Duchem Świętym, ale o ukazanie Jego oddziaływania na Nią i Jej odpowiedzi. Trzeba pamiętać, że wręcz niemożliwe jest mówienie o Maryi i o Jej roli w ekonomii zbawienia bez odniesienia się do Jej relacji z Duchem Świętym. Jednoznacznie opowiadają się za tym teologowie zarówno katoliccy (np. René Laurentin, Antonio Contri), jak i prawosławni (np. Nikos Nissiotis) oraz protestanccy (Horst Gorski).

\subsubsection{Poczęcie Syna Najwyższego przez Maryję w Duchu Bożym}

Święty Mateusz pisze, że Maryja „wpierw nim zamieszkali razem [z Józefem - przyp. A. N.], znalazła się brzemienną za sprawą Ducha Świętego" (Mt 1, 18) i że porodzi Syna, który zbawi lud Izraela od grzechów. Szczególnie jednak interesujące jest w tym względzie sformułowanie Łukasza: „Duch Święty zstąpi na Ciebie i moc Najwyższego osłoni Cię. Dlatego też Święte, które się narodzi, będzie nazwane Synem Bożym" (Łk 1, 35). Ewangelista za pomocą tych dwóch obrazów oddaje działanie Ducha Świętego.

Obraz pierwszy: „Duch Święty zstąpi na Ciebie”. Anioł wyjaśnia, w jaki sposób Maryja będzie Matką Mesjasza. Stanie się to dzięki szczególnemu działaniu Ducha. Duch Święty, dany Maryi w tym momencie, objawia się jako moc stwórcza (Spiritus Creator), która wzbudza nowe życie.

Obraz drugi: „moc Najwyższego osłoni Cię". Działanie „mocy Najwyższego" opisuje Łukasz czasownikiem „osłonić” (episkiazein). Dosłownie oznacza on „otoczyć kogoś obłokiem”, „przykryć”, „osłonić”. Łukasz prawdopodobnie czyni tu aluzję do Wj 40, 35: „Wtedy to obłok okrył Namiot Spotkania, a chwała Pana napełniła przybytek. I nie mógł Mojżesz wejść do Namiotu Spotkania, bo spoczywał na nim obłok i chwała Pana wypełniała przybytek". Obłok osłaniający Maryję wskazuje na obecność w Niej Boga. Bardziej zdawkowo wyraża to Mateusz, pisząc: „albowiem z Ducha Świętego jest to, co się w Niej poczęło” (Mt 1, 20). W wyrażeniu „z Ducha Świętego" zawarta jest szczególna koncentracja teologiczna.

Syn Najwyższego stał się w łonie Dziewicy przez Ducha prawdziwym człowiekiem, podobnym nam we wszystkim oprócz grzechu. Bóg upodobał sobie w ludzkim ciele. Ciało to jest dobre i święte, jeśli je przyjął Syn Najwyższego. Jezus Chrystus, istotowo zjednoczony z Bogiem, równocześnie jest najpiękniejszy z ludzi. Bóg nie alienuje człowieka, ale go podnosi na wyższy poziom duchowej egzystencji. W tajemnicy wcielenia Duch Święty został objawiony nie tylko jako źródło piękna, lecz także źródło 
świętości: „Dlatego też Święte, które się narodzi, będzie nazwane Synem Bożym”. Duch zwiastowania zasługuje zatem na miano Spiritus Sanctificator. To On najpierw uświęcił Maryję, zwracając się do niej słowami: „pełna łaski”, „Pan z Tobą", „Błogosławiona”.

\subsubsection{Charyzmaty służebne Maryi}

Oprócz poczęcia i zrodzenia Bożego Syna Maryja została jeszcze dodatkowo wyposażona darami Ducha Świętego. Owocem działania w Niej drugiej Osoby Boskiej są charyzmaty służebne.

Zaraz po zwiastowaniu ( $Ł k$ 1, 38) Maryja nie udała się do Jerozolimy, by w świątyni podziękować za dar Ducha Świętego i za powołanie na Matkę Syna Najwyższego (Łk 1,32), lecz „wybrała się i poszła z pośpiechem w góry do pewnego miasta w [pokoleniu] Judy" (Łk 1, 39), do domu Zachariasza i Elżbiety, czyli do dwojga starszych ludzi i do matki spodziewającej się dziecka. Ponieważ na powołujący głos Boży Maryja odpowiedziała wiarą, została uzdolniona Boską osobową Pneumą i mogła ponieść do innych ludzi Ducha Świętego, a wraz z Nim radość i pomoc. Dlatego w teologii wschodniej Matka Boża nazywana jest Nosicielką Ducha (Pneumatophora). Spotkanie z Bogiem i napełnienie Duchem domaga się zwieńczenia w spotkaniu z ludźmi. Kto na Boże powołanie z entuzjazmem odpowiada „tak” - ten zawsze będzie szedł z pośpiechem, by służyć innym. Maryja została obdarzona podwójnym charyzmatem spotkania: otwarcia się na Boga i pochylenia nad człowiekiem, i to człowiekiem słabym („opcja na rzecz ubogich”)

Zastanawiające jest, dlaczego Maryja jako kobieta brzemienna nie pozostała w Nazarecie. Do troski o Elżbietę na pewno trzeba dołączyć Jej własną troskę o oczekiwane dzieciątko, które już od trzech miesięcy nosiła pod sercem. Ten fakt napełnił Ją bez wątpienia radością. Potrzebowała samotności, a górski klimat Ain Karim doskonale się do tego nadawał. Ponadto jako kobieta pragnęła podzielić się tym szczęściem z osobą sobie życzliwą. Również nieznośna atmosfera oszczerstw i pomówień Nazaretu, które dotykały Maryję niebędącą jeszcze w oficjalnym związku z Józefem, była najprawdopodobniej czynnikiem popychającym Ją w ustronne miejsce. Można tu zauważyć charyzmat roztropności - Maryja wiedziała, jak postąpić w trudnych chwilach.

\footnotetext{
2 Por. J. Kudasiewicz, Odkrywanie Ducha Świętego..., dz. cyt., s. 135-143.

3 Interesująco na temat duchowości ubogich pisze: J. Kiciński, Maryja wzorem duchowości ubogich (wokół ślubu ubóswa), SM 17 (2015) nr 1-4, s. 49-6o.
} 
Charyzmaty są przeznaczone dla wspólnoty, dlatego Maryja „poszła z pośpiechem w góry", aby dzielić się dobrym słowem, radością, Duchem Świętym i zwyczajną ludzką pomocą - aby służyć. Duch Święty obdarza nie tylko charyzmatami nadzwyczajnymi, jak dar języków, prorokowanie, uzdrawianie, czynienie cudów, lecz także charyzmatami służebnymi, do których zaliczają się: czynności diakońskie (por. $\mathrm{Rz} 12,7$ ), wspieranie pomocą (1 Kor 12, 28), wykonywanie posługi (Ef 4, 12) czy też dzielenie się własnym szczęściem. Są to tzw. charyzmaty ewangelicznej Marty. Duch Święty obdarzył nimi Maryję w momencie zwiastowania. Dlatego szybko udała się Ona w Góry Judzkie, aby realizować te właśnie dary. Droga Maryi nie jest drogą cudowną i nadzwyczajną, ale drogą pokornej służby. I dlatego właśnie, nazywając się „pokorną służebnicą”, stała się Ona pierwszą charyzmatyczką Kościoła. Jedynie Maryja była zdolna wyśpiewać tak wspaniały hymn uwielbienia, jakim jest Magnificat. Duch Święty zaowocował w Jej sercu. "Owocem zaś ducha jest: miłość, radość, pokój, cierpliwość, uprzejmość, dobroć, wierność, łagodność, opanowanie. Przeciw takim [cnotom] nie ma Prawa" (Ga 5, 22n). Takich właśnie owoców ducha potrzebuje współczesna ludzkość bardziej niż cudów w sensie niezwykłego fenomenu czy glosolalii ${ }^{4}$.

\subsubsection{Modlitwa Maryi: owoc Ducha Świętego}

Duch Święty inspirował nie tylko charyzmaty służebne Maryi, lecz także Jej modlitwę. Świadczy o tym hymn uwielbienia Boga - Magnificat, wyśpiewany przez Nią po napełnieniu Duchem Świętym w czasie zwiastowania $(Ł k 1,35)$. Jest to pierwsza udokumentowana przez św. Łukasza modlitwa: „Wielbi dusza moja Pana i raduje się duch mój w Bogu, moim Zbawcy” $(1,46)$. Hymn ten jest pieśnią uwielbienia, modlitwą całkowicie bezinteresowną, nie ma w niej ani jednego słowa prośby. Maryja jest zafascynowana wielkością, świętością i miłosierdziem zbawiającego Boga.

Drugi rodzaj modlitwy, o którym dwukrotnie wspomina św. Łukasz $(2,19.51)$, to "rozważanie w sercu”, czyli medytacja, kontemplacja. Dziewica z Nazaretu rozważała to, co o Jezusie objawili aniołowie pasterzom - podczas gdy inni poprzestawali na dziwieniu się tym wydarzeniom. Przemyśliwała także słowa swojego Syna, który powiedział, gdy Go odnaleziono w świątyni jerozolimskiej: „Potrzeba, abym był w sprawach Ojca mojego” (Łk 2, 49). Maryja wnikała w słowa Jezusa, w słowo Boże, w słowo Ewangelii.

4 Por. J. Kudasiewicz, Odkrywanie Ducha Świętego..., dz. cyt., s. 146-149. 
Następny obszar modlitwy i duchowości Maryi odsłania się wraz z Jej udziałem w pobożności ludowej, gdyż uczestniczyła Ona w pielgrzymkach do Świętego Miasta z okazji Paschy (Łk 2, 21. 38. 41-52). Prawo żydowskie nakazywało trzy razy w roku pielgrzymować do świątyni jerozolimskiej (Pwt 16, 16). Pielgrzymowanie było połączone ze śpiewem psalmów. Matka Najświętsza znała je na pamięć, śpiewała je wraz z innymi pątnikami, żyła tą modlitwą ludu. Najprawdopodobniej miała też nawet swoje ulubione psalmy.

Czwarta przestrzeń modlitwy Maryi to modlitwa rodzinna ( $\left.\operatorname{lk}_{1}, 41\right)$. Była ona mocno związana $\mathrm{z}$ historią Izraela, $\mathrm{z}$ wielkimi interwencjami Bożymi w dzieje ludu wybranego. Wyśpiewywane przez Maryję Magnificat jest hymnem pochwalnym na cześć Jahwe. Święty Lukasz pokazuje w ten sposób, jak religijność Izraela wpływała na formację Maryi. Uczestnictwo w pielgrzymkach, udział w liturgii świątynnej, coroczne wieczerze paschalne $z$ haggadą ojca rodziny, Joachima, i z matką Anną miały żywy oddźwięk w Jej życiu. Nie zrozumiemy Maryi, gdy Ją oderwiemy od tego ludu, od religijności i zwyczajów Izraelitów. Modlitwa Maryi bez tego kontekstu zawieszona jest w próżni.

Czego uczy nas Maryja? Po pierwsze tego, że nie ma i nie powinno być sprzeczności między autentyczną pobożnością ludową a pobożnością prawdziwych mędrców, między pobożnością wspólnotową (pielgrzymki, liturgia, zbiorowy śpiew psalmów) a pobożnością osobistą, która znajduje swój wyraz w wyciszonej medytacji w głębi serca. Po drugie, wzór Maryi rozważającej w sercu przypomina Kościołowi wszystkich czasów o wyższości kontemplacyjnego wymiaru chrześcijańskiego życia, o konieczności nieustannego wspominania i rozważania słów Ewangelii 5 . Dla teologów, kapłanów i wszystkich ewangelizatorów to wskazanie na priorytet modlitwy w stosunku do intelektualnej refleksji czy praktycznej działalności.

Piąty wymiar modlitwy Maryi sprowadzić można do modlitwy wspólnotowej (Dz 1, 14: „Wszyscy oni [apostołowie] trwali jednomyślnie na modlitwie razem z niewiastami, Maryją, Matką Jezusa, i braćmi Jego"). Matka Jezusa modli się w pierwotnym Kościele, z Kościołem i za Kościół; modli się tak, jak wszyscy tworzący wspólnotę jerozolimską. Jest to prawdziwa modlitwa eklezjalna. Cechuje się tym, że uczestniczą w niej wszyscy; ponadto jest ona wytrwała i jednomyślna. Zesłanie Ducha Świętego (Dz 2, 1-4) jest odpowiedzią na tę jednomyślną modlitwę pierwotnej wspólnoty, zgromadzonej

\footnotetext{
Por. tamże, s. 155-157.
} 
w Wieczerniku wokół modlącej się Matki, która przecież także błagała o ten dar: „Kiedy nadszedł wreszcie dzień Pięćdziesiątnicy, znajdowali się wszyscy na tym samym miejscu" ( $\mathrm{Dz} 2,1)$. Z Łukaszowego zapisu, widzianego w kontekście Ewangelii i Dziejów, wynika zatem szczególny związek między Maryją, Duchem Świętym i Kościołem.

Maryja, pierwsza charyzmatyczka Kościoła, uczy korzystania z Bożych darów. Modlitwa językami pojawia się w Jej życiu na ostatnim miejscu. Uczy Ona w ten sposób, że ten rodzaj modlitwy nie jest pierwszy ani najważniejszy. Na pierwszej pozycji w Jej życiu jest modlitwa uwielbienia - Magnificat. I to pozwala Jej harmonijnie łączyć modlitwę z miłością ${ }^{6}$.

Biblijny przekaz o Maryi, obejmujący trzy podstawowe wydarzenia (zwiastowanie, nawiedzenie oraz wyśpiewanie hymnu Magnificat) tworzy pewnego rodzaju tryptyk. Jego teologiczna interpretacja niesie ze sobą całe bogactwo treści. Niemniej jednak zwiastowanie należy postrzegać przede wszystkim jako napełnienie mocą Bożą; Maryja staje się pełna łaski. Z duchowej pełni darów, które otrzymała dzięki wierze, staje się pełną łaski także w sensie fizycznym, gdyż od tej chwili nosi w swoim kobiecym łonie - już nie tylko w sercu - odwieczne Słowo Boże, które stało się ciałem. Scena nawiedzenia dowodzi, że tylko człowiek nasycony łaską może iść i głosić Boga. Wówczas ma kogo i co przepowiadać, gdyż wypełniony jest Bożym Duchem. Jest uzdolniony nie tylko co do treści, lecz także i co do samej funkcji. Maryja podąża do Elżbiety jako pierwsza apostołka, pierwsza misjonarka. Matka Pana jest zdolna do pomocy innym, gdyż bez zastrzeżeń daje się prowadzić Duchowi swego Syna. Magnificat jako trzecia scena to dziękczynienie. Przepełniona radością Maryja nie może nie wyśpiewywać wielkich rzeczy, które Pan dla Niej i przez Nią uczynił. I tak rysuje się przed naszymi oczyma podwójny tryptyk: zwiastowanie - nawiedzenie Magnificat oraz wiara - świadectwo - modlitwa.

\subsection{Jedność Maryi z Duchem Trójjedynego Boga}

Zaangażowanie Najświętszej Maryi Panny w zbawcze dzieło Jezusa Chrystusa wynikało z Jej niezwykłej jedności z trzecią Osobą Boską. Przywołamy teraz najistotniejsze elementy z życia Maryi, które wydają się wyznaczać i konstytuować Jej głęboką jedność z Duchem Świętym. Trzeba odkrywać

\footnotetext{
6 Por. tamże, s. 158-161.
} 
miejsce Maryi w ekonomii Ducha, gdyż jest Ona zarówno Jego a n a m n e zą (pamiątką), jak i e piklezą (przywołaniem). Wciąż za mało ukazywania Maryi jako Oblubienicy Ducha Świętego ${ }^{7}$.

\subsubsection{Niepokalane poczęcie}

Niekwestionowanym fundamentem zjednoczenia Maryi z Duchem Świętym jest oczywiście fakt Jej Bożego macierzyństwa. Jednakże było ono czasowo uprzedzone przez niepokalane poczęcie, w którym należy widzieć pierwszą maryjną epifanię Ducha Świętego. Słowa anioła Gabriela wypowiedziane do Maryi w chwili zwiastowania: „Raduj się, pełna łaski! Pan z Tobą!”, oznaczają i potwierdzają, że Duch Święty już wcześniej, tzn. w momencie poczęcia Maryi, zstąpił na Nią, jednocząc się z Nią i wypełniając Ją pełnią swojej łaski. Przekonanie to występuje nie tylko w bulli Piusa Ix dogmatyzującej niepokalane poczęcie, lecz także w tekście Soboru Watykańskiego II, gdzie czytamy:

u świętych Ojców przyjął się zwyczaj nazywania Bogarodzicy całą świętą i wolną od wszelkiej zmazy grzechowej, jakby utworzoną przez Ducha Świętego i ukształtowaną jako nowe stworzenie. Ubogaconą od pierwszej chwili poczęcia blaskami szczególnej zaiste świętości. Dziewicę z Nazaretu zwiastujący Anioł z polecenia Bożego pozdrawia jako „łaski pełną” (Łk 1, 28), ona zaś odpowiada wysłańcowi niebios: „Otom ja, służebnica Pańska, niechaj mi się stanie według słowa twego" $(\text { Łk 1, 38) })^{8}$.

Maryja Niepokalana jest Arcydziełem Ducha Świętego; jest Nowym Stworzeniem, konsekwencją działania tegoż Ducha w chwili Jej poczęcia. W wyniku tego uświęcającego działania od pierwszej chwili swojego istnienia Najświętsza Maryja Panna jest na stałe zjednoczona z trzecią Osobą Boską. Pogląd ten spotykamy zarówno u św. Maksymiliana M. Kolbego, jak i u św. Jana Pawła II ${ }^{9}$. Maryja miała świadomość, że Boży Duch wziął Ją w posiadanie. Wybrzmi to w słowach Pawła Apostoła, które możemy odnieść do wszystkich wierzących w Jej Syna: „Czyż nie wiecie, żeście świątynią Boga i że Duch Boży mieszka w was?” (1 Kor 3, 16).

\footnotetext{
7 Por. K. Guzowski, Duch dialogujacy. Zarys pneumatologii dialogalnej, Lublin 2016, s. 343356.

KK 56.

9 Por. G. Bartosik, Mediatrix in Spiritu Mediatore, dz. cyt., s. 330-331.
} 
To ścisłe zjednoczenie Maryi już w chwili Jej poczęcia z Duchem Świętym pozwoli nie tylko na realizację misterium inkarnacji, lecz także da Jej możliwość pośredniczenia w pośrednictwie trzeciej Osoby Boskiej w kolejnych etapach zbawczej historii Kościoła.

\subsubsection{Wcielenie Syna Bożego}

Punktem kulminacyjnym głębokiej jedności Najświętszej Dziewicy z Nazaretu i trzeciej Osoby Boskiej był moment wcielenia Syna Bożego w Jej łono. Możemy tu mówić o aspekcie obiektywnym i subiektywnym.

Aspektem obiektywnym tego zjednoczenia jest osoba wcielonego Syna Bożego. Duch Święty i Maryja spełniają w tym wydarzeniu misję pośredniczącą. Natomiast aspektem subiektywnym jest ścisła więź, jaka towarzyszy inkarnacji, zachodząca między osobą Matki Syna Bożego a trzecią Osobą Boską. To zjednoczenie spełnia się na płaszczyźnie posłuszeństwa i dyspozycyjności Maryi względem Ducha Świętego oraz na płaszczyźnie Jej oblubieńczego (pełnego miłości) związku z Parakletem. Maryja staje się oblubienicą Ducha Świętego, gdyż jest posłuszna Ojcu Niebieskiemu ${ }^{10}$ dlatego też przyjmuje dar dziewiczego macierzyństwa. Jednocześnie jest Ona wzorem akceptacji woli Boga i tym samym zdolna do przemiany, czyli kroczenia drogą świętości ${ }^{11}$.

\subsubsection{Boże macierzyństwo}

Fakty niepokalanego poczęcia oraz wcielenia skutkują tajemnicą narodzin Jezusa Chrystusa i uzewnętrzniają się w niej. Dzięki współdziałaniu Ducha Świętego z wolną wolą Maryi poczyna Ona najpierw Jezusa w wierze, przyjmując odwieczne Słowo do swojego serca i ciała, aby następnie zrodzić Je również biologicznie. $Z$ jednej strony nie jesteśmy nawet $\mathrm{w}$ stanie wyobrazić sobie tej ogromnej duchowej mocy udzielonej Maryi, a z drugiej pojąć subtelności i delikatności, z jaką oddziaływała trzecia Osoba Boska.

Sobór Watykański in stwierdza:

Tak więc Maryja, córka Adama, zgadzając się na słowo Boże, stała się Matką Jezusa, a przyjmując zbawczą wolę Bożą całym sercem, wolna od wszelkiego grzechu całkowicie poświęciła samą siebie, jako służebnicę Pańską, osobie i dziełu swego Syna, pod Jego zwierzchnictwem i razem z Nim z łaski Boga

${ }^{10}$ Por. tamże, s. 343-368.

${ }^{11}$ Por. I. Werbiński, Posłuszeństwo Ojcu droga świętości Maryi, sm 1 (1999) nr 4, s. 30-43. 
wszechmogącego służąc misterium odkupienia. Słusznie tedy sądzą święci Ojcowie, że Maryja nie została tylko biernie użyta przez Boga, lecz wolną wiarą i posłuszeństwem współpracowała w dziele ludzkiego zbawienia. Sama bowiem, jak mówi św. Ireneusz, „będąc posłuszna, stała się przyczyną zbawienia zarówno dla siebie, jak i dla całego rodzaju ludzkiego"12.

Wydarzenie Bożego macierzyństwa jest efektem rezygnacji Maryi z siebie. Na ile człowiek zrezygnuje z siebie, na tyle w nim i przez niego działa Trójca Święta. Chodzi o to, aby oddać do Jej dyspozycji wszystkie przymioty swojej natury i ducha, czyli dobrowolnie wyniszczyć samego siebie. Maryi udało się to $\mathrm{w}$ stopniu najwyższym. Dobrowolnie rezygnując $\mathrm{z}$ własnej inicjatywy, a przyznając prawo wyłącznie Bożemu działaniu, Maryja stała się rzeczywiście współdziałającą. Adrienne von Speyr zauważa, że:

współpraca z dziełami łaski jest bowiem zawsze owocem rezygnacji. Rezygnując ze wszystkich swoich możliwości rozwoju, [Maryja - przyp. A. N.] uzyska ich spełnienie ponad wszelkie oczekiwanie: współdziałając w ciele, zostanie Matką Pana; współdziałając w duchu - Jego Służebnicą i Oblubienicą. Służebnica staje się Matką, a Matka Oblubienicąa

W tej ścisłej jedności Maryi z Nazaretu z trzecią Osobą Trójcy Świętej spełnia się kolejny etap dziejów zbawczych, kiedy obdarza Ona odwieczne Słowo Boże ludzką naturą. Duch Święty przez Nią wprowadza na świat największy dar, jakim jest sam Bóg w ludzkiej postaci - Jezus Chrystus. Bóg nie mógł nam ofiarować nic większego i wspanialszego.

\subsubsection{Uczestnictwo Maryi w dziełach zbawczych}

Najświętsza Maryja Panna, będąc tak głęboko zjednoczona z Duchem Świętym, efektywnie mogła uczestniczyć w całej historii zbawienia oraz nadal skutecznie wypraszać łaski i dary dla pielgrzymującego Ludu Bożego, który zawiązuje się w sposób ostateczny wokół Jezusa z Nazaretu i jako Kościół kroczy nieustannie także dziś ku swojemu eschatycznemu spełnieniu.

Kolejne epifanie Ducha Świętego w osobie i czynach Maryi ujawniają się w trakcie ziemskiego życia Jezusa Chrystusa. Pneumatycznie trzeba przede wszystkim interpretować takie wydarzenia, jak: 1. scena nawiedzenia

12 KK 56.

13 A. von Speyr, Stużebnica Pańska, przeł. J. Koźbiał, Warszawa 1998, s. 7. 
św. Elżbiety, 2. ofiarowanie Nowonarodzonego w świątyni i proroctwo Symeona, 3. odnalezienie nauczającego w świątyni Jezusa, 4. cud w Kanie Galilejskiej, 5. sytuacja u stóp krzyża w chwili śmierci Chrystusa oraz 6. zesłanie Ducha Świętego.

Związek Maryi z Jej Boskim Synem - dzięki Duchowi Świętemu - w tych sześciu scenach, mający swoje biblijne zakotwiczenie, opisuje także Konstytucja dogmatyczna o Kościele Lumen gentium. Czytamy w niej:

Łączność Matki z Synem w dziele zbawczym uwidacznia się w chwili dziewiczego poczęcia Chrystusa i trwa aż do Jego śmierci; najpierw, gdy Maryja udaje się z pośpiechem, aby odwiedzić Elżbietę, a ta, powodując się wiarą w obiecane zbawienie, pozdrawia Ją jako błogosławioną [...]; ponownie w momencie narodzenia, gdy Boża Rodzicielka z radością ukazuje pasterzom i mędrcom swego pierworodnego Syna, który nie naruszył Jej dziewictwa, lecz je uświęcił [...]. Kiedy zaś przedstawiła Go Bogu w świątyni złożywszy dar ubogich, usłyszała Symeona zapowiadającego równocześnie, że Syn będzie znakiem sprzeciwu i że duszę Matki przeniknie miecz, aby wyszły na jaw zamysły serc wielu (por. Łk 2, 34n). Zagubione i z bólem szukane Dziecię Jezus odnaleźli Jego rodzice w świątyni, gdy było zajęte tym, co należało do Jego Ojca, i nie zrozumieli słów Syna. Jego Matka jednak, gorliwie rozważając, zachowywała to wszystko w swoim sercu. W życiu publicznym Jezusa Jego Matka pojawia się w sposób znamienny, i to na [...] weselu w Kanie Galilejskiej, przejęta litością, spowodowała swym wstawiennictwem początek znaków Jezusa jako Mesjasza (por. J 2, 1-11). [...] Błogosławiona Dziewica postępowała naprzód w pielgrzymce wiary i utrzymywała wiernie swe zjednoczenie z Synem aż do krzyża, pod którym stanęła nie bez postanowienia Bożego (por. J 19, 25), najgłębiej współpracowała ze swym Jednorodzonym i z Jego ofiarą złączyła się matczynym duchem, z miłością godząc się na ofiarowanie zrodzonej z Niej Żertwy [...]. Widzimy Apostołów przed dniem Pięćdziesiątnicy, „trwających jednomyślnie na modlitwie razem z niewiastami, z Maryją Matką Jezusa, i z braćmi Jego" (Dz 1, 14), a także Maryję błagającą modlitwami o dar Ducha, który okrył Ją już cieniem podczas zwiastowania ${ }^{14}$.

W każdym z tych wydarzeń (nawiedzenie, ofiarowanie i proroctwo, odnalezienie, przemiana wody w wino, śmierć Jezusa, Pięćdziesiątnica) Maryja pogłębia swoją więź z Duchem Świętym. Oznacza to, że wydoskonala

${ }^{14}$ KK 57-59. 
się w Duchu. Wydarzeń tych nie można zrozumieć bez uwzględnienia ich pneumatologicznej interpretacji. Mają one także swój eklezjologiczny wymiar, co widać szczególnie wyraźnie w chwili konania Jezusa na krzyżu i w tajemnicy zesłania Ducha Świętego. Duch Jezusa jest bowiem Duchem Kościoła.

We współczesnej teologii moment śmierci Jezusa na drzewie krzyża interpretuje się jako czas przekazania Ducha Świętego Kościołowi, reprezentowanemu u stóp krzyża przez Maryję. Scena krzyża w Ewangelii św. Jana (J 19, 25-29) składa się z tzw. testamentu Jezusa oraz z Jego ostatniego tchnienia, kiedy swego ducha - oddając go Bogu Ojcu - przekazuje On wspólnocie u stóp krzyża, której przewodniczy Maryja, jako jedyna przechowująca w tym tragicznym momencie całą wiarę młodego Kościoła. Ten sam Duch, którego Chrystus przekazał w chwili swojej śmierci swej Matce, czyni Ją także Matką duchową nie tylko umiłowanego ucznia Jezusowego, lecz także wszystkich wierzących w Jezusa jako Chrystusa, czyli chrześcijan. Na Kalwarii zstępuje na Maryję Duch Jezusa, który jest przecież Duchem Trójjedynego Boga, aby dać początek Mistycznemu Ciału Jezusa - Kościołowi. Tak oto Maryja staje się Matką Chrystusowego Kościoła.

Jeszcze wyraźniejszą pneumatologiczną interpretację należy wyprowadzić z momentu zesłania Ducha Świętego na zgromadzonych w wieczerniku, gdzie Maryja modli się wraz z uczniami.

Kiedy nadszedł wreszcie dzień Pięćdziesiątnicy, znajdowali się wszyscy razem na tym samym miejscu. Nagle dał się słyszeć z nieba szum, jakby uderzenie gwałtownego wiatru, i napełnił cały dom, w którym przebywali. Ukazały się im też języki jakby z ognia, które się rozdzieliły, i na każdym z nich spoczął jeden. I wszyscy zostali napełnieni Duchem Świętym, i zaczęli mówić obcymi językami, tak jak im Duch pozwalał mówić (Dz 2, 1-4).

Maryja i apostołowie zostają ogarnięci przez Ducha Świętego i obfitość Jego różnych darów, a tym samym tyczy się to chrześcijan wszystkich epok. Wielu teologów z tego zbawczego wydarzenia wyprowadza funkcję pośrednictwa Maryi dla całego Kościoła.

Te wszystkie wydarzenia zbawcze objawiają ścisłą więź Maryi z Duchem Bożym. Jej zjednoczenie z trzecią Osobą Boską najpierw Ją przygotowuje i uzdalnia do zrodzenia Syna Bożego, aby w tajemnicy rzeczywistego macierzyństwa - w porodzeniu Jezusa - osiągnąć swoją pełnię. Później - dzięki 
Parakletowi - Maryja kontynuuje to macierzyństwo jako duchowe już wobec Chrystusa mistycznego, czyli Jego Kościoła ${ }^{15}$.

\subsection{Formy i sposoby jedności Maryi z Duchem Boga}

Wśród całego szeregu modeli i sposobów zjednoczenia Maryi z Duchem Świętym można wyróżnić cztery zasadnicze:

1. synergia w działaniu między Duchem Świętym a Maryją;

2. Maryja jako przybytek (świątynia, sanktuarium) Ducha Bożego;

3. Maryja obrazem i ikoną Ducha Świętego;

4. Maryja objawieniem i przejrzystością Ducha Pańskiego ${ }^{16}$.

Modelem najbardziej przydatnym do pneumahagijnego wyjaśniania jedności Maryi z Duchem Boga jest sy n e r g i a ${ }^{17}$. Greckie słowo synergeia oznacza współdziałanie ludzko-boskie, które jest wynikiem zamieszkiwania Boga w człowieku. Trójca Święta zamieszkuje w człowieku usprawiedliwionym, kierując nim, uświęcając go i oświecając jego życie wewnętrzne. We wszystkich działaniach Najświętszej Maryi Panny, tak w czasie Jej ziemskiego życia, jak i po wniebowzięciu, działa Ona w doskonałej harmonii i zgodzie z trzecią Osobą Boską, czyli Jej wola jest ściśle zjednoczona z wolą Ducha Świętego. Metodę synergii odnajdujemy u ojców Kościoła, a zwłaszcza u św. Grzegorza Palamasa (1296-1357), a później u św. Jana od Krzyża (1542-1691) i św. Maksymiliana M. Kolbego.

Jedność Maryi z Duchem Świętym wyraża także model przybytku (świątyni, sanktuarium). Tę myśl teologiczną wyprowadza się z Pisma Świętego i nauczania ojców Kościoła. Potwierdza ją także Sobór Watykański II słowami:

Maryja Dziewica, która przy zwiastowaniu anielskim przyjęła sercem i ciałem Słowo Boże i dała światu Życie, jest uznawana i czczona jako prawdziwa Matka Boga i Odkupiciela. Odkupiona w sposób wznioślejszy ze względu na zasługi Syna swego i zjednoczona z Nim ścisłym i nierozerwalnym węzłem, obdarzona jest tym najwyższym darem i najwyższą godnością, która wynika $z$ tego,

\footnotetext{
${ }_{15}$ Por. A. A. Napiórkowski, Bosko-ludzka wspólnota..., dz. cyt., s. 106-120.

${ }^{16}$ Por. G. Bartosik, Mediatrix in Spiritu Mediatore, dz. cyt., s. 379.

${ }_{17}$ Przez „synergię” rozumiemy współdziałanie łaski Bożej i woli ludzkiej dla realizacji historii zbawienia.
} 
że jest rodzicielką Syna Bożego i dlatego najbardziej umiłowaną córką Ojca i przybytkiem Ducha Świętego. Dzięki temu darowi szczególnej łaski znacznie przewyższa wszystkie inne stworzenia, niebieskie i ziemskie ${ }^{18}$.

Określenie Maryi jako przybytku Ducha Świętego (sanktuarium) jest wyraźnym nawiązaniem do Starego Testamentu, gdzie świątynia jerozolimska była miejscem przebywania Jahwe. Skoro Duch Święty spoczął na Maryi (zacienił Ją, zamieszkał w Niej), to stała się Ona Matką Syna Bożego.

Interesującą refleksję na temat Maryi jako świątyni Ducha Świętego w perspektywie eklezjologicznej przedstawił Yves Congar. Francuski teolog uważał, iż w odniesieniu do Maryi poprawniejszy jest tytuł „Świątynia Ducha Świętego” niż „Oblubienica Ducha Świętego”, ponieważ oblubieńcza miłość odnosi się do trzech Osób Boskich. Maryję należy też postrzegać w kontekście wiary w Chrystusa i Ducha Świętego, w przeciwnym razie narażamy się na zarzut przenoszenia na Nią ich funkcji. Rola Maryi mieści się w roli Ducha Świętego ${ }^{19}$.

Relację Maryi z Duchem Bożym tłumaczy także model obrazu i i kony. Każdy człowiek przez sam fakt stworzenia jest obrazem i podobieństwem Boga (por. Rdz 1, 27). Najdoskonalszym obrazem Trójjedynego jest Syn Boży, który przyjął ludzką naturę i nigdy nie popełnił grzechu. Ikonografem jest natomiast Duch Święty, który ma pisać ikonę Boga w każdym człowieku; On jest tym, który sprawia usprawiedliwienie w grzeszniku, dokonuje jego uświęcenia i zbawienia, czyli udoskonala i upiększa obraz Jezusa Chrystusa w ludzkiej osobie. A ponieważ w Maryi zamieszkał Duch Święty już w momencie Jej niepokalanego poczęcia, ocienił Ją w momencie zwiastowania i kierował Nią w chwili narodzin Jezusa, jest Ona bez wątpienia najdoskonalszym obrazem i ikoną Ducha Bożego. Maryja jest nosicielką Ducha Trójjedynego, czyli Pneumatoforą, jest Służebnicą Pańską, Bożą Rodzicielką, Matką Kościoła. Maryja jest osobą ludzką, w zupełnie „przezroczysty” sposób poddającą się działaniu Parakleta. Choć nie jest Ona wcieleniem Ducha Świętego, to - jak pisze Siergiej Bułgakow - jest „objawieniem hipostatycznym” Ducha.

Mówiąc o głębokim zjednoczeniu Maryi z trzecią Osobą Boską, warto zaznajomić się z innym jeszcze modelem teologicznym, który ukazuje Ją jako objawienie i przejrzystość Ducha Świętego. Święty Maksymilian

\footnotetext{
${ }^{18}$ KK 53.

19 Por. S. C. Napiórkowski, Maryja w teologii, dz. cyt., k. 22.
} 
Maria Kolbe pisał: „Matka Najświętsza jest po to, aby lepiej poznano Ducha Przenajświętszego". Zatem to nie tylko działanie Ducha Bożego odsłania Maryję z Nazaretu i Jej zbawcze pośrednictwo w pośrednictwie Jezusa Chrystusa, lecz także sama Maryja swoim posłuszeństwem i zaangażowaniem w wydarzeniach historii zbawienia objawia Osobę i działanie Ducha Świętego. Maryja odsłania Ducha Świętego przede wszystkim w momencie wcielenia, gdyż Duch Boga poprzez Maryję objawił wówczas z jednej strony swoją misję wewnątrztrynitarną, a z drugiej swoją misję wobec ludzi. Niektórzy teologowie stoją na stanowisku, że Maryja objawia Ducha Świętego całym swoim życiem i misją. Inni jeszcze akcentują odsłanianie się Ducha w darach i charyzmatach udzielanych Maryi. Z kolei św. Edyta Stein uważa, że Maryja objawia Ducha w życiu chrześcijanina.

Dopełnieniem modelu objawienia jest określenie Maryi jako przejrzystości (transparencji) Ducha Świętego. Podkreśla się w nim zwłaszcza to, że osoba i czyny Maryi są przeniknięte obecnością i działaniem Ducha Świętego aż do momentu, w którym staje się Ona przezroczysta dla Parakleta. Kontemplując Ją, widzimy jakby samego Ducha Bożego. Takie ujęcie jest zasługą szczególnie Xabiera Pikazy. Ten hiszpański teolog swoją koncepcję Maryi jako przejrzystości Ducha Świętego uzasadnia w pięciu punktach:

1. Maryja, będąc córką Narodu Wybranego, była całkowicie otwarta na Ducha Jahwe działającego w historii Jej Narodu;

2. otrzymując pełnię łaski, odebrała również pełnię darów Ducha, co zaowocowało tym, że stała się Bożą Rodzicielką;

3. będąc wierną uczennicą Jezusa, kierowała i kieruje nadal ludzi do Chrystusa, co jest darem Ducha;

4. Maryja otrzymuje Ducha wraz z apostołami na początku istnienia Kościoła;

5. jako Niewiasta (figura Kościoła) odnosi zwycięstwo nad szatanem i jest znakiem obecności Ducha Bożego w Kościele ${ }^{20}$.

${ }^{20}$ Por. G. Bartosik, Mediatrix in Spiritu Mediatore, dz. cyt., s. 379-404; por. A. Amato, Maryja w walce z szatanem we współczesnym świecie [brak inf. o tłum.], SM 13 (2011) nr 1-2, s. 62-80. 


\section{Maryja w dziele odkupienia}

Ukazanie podstawowych pięciu prawd wiary odnoszących się do Najświętszej Maryi Panny oraz Jej związków z Duchem Świętym w żadnym wypadku nie jest wystarczające. Dalsze ukazywanie bogactwa doktryny Kościoła na Jej temat musi skupić się na rekonstrukcji roli Maryi jako Matki Jezusa i Jej funkcji w Bożej ekonomii zbawienia ${ }^{1}$. Spośród wielu innych kwestii mariologicznych omówimy teraz najważniejsze następujące aspekty katolickiej nauki o Matce Chrystusa: współdziałanie Maryi w dziele odkupienia, Jej pośrednictwo, macierzyństwo duchowe oraz funkcję w tajemnicy Kościoła. Chodzi tu o udział Maryi w dziele zbawczym jej Syna. Maryja jest bowiem piękna - co stanowi myśl przewodnią niniejszej publikacji - gdyż jest związana nie tylko z osobą Jezusa, lecz także z dziełem Chrystusa, który już jako paschalny Pan wciąż się udziela swoim naśladowcom i całemu światu².

Problematyka Maryi jako współpracownicy Boga - a zwłaszcza pytanie o rodzaj i sposób Jej zaangażowania w historię zbawienia - stanowi jedną z trudniejszych kwestii mariologii. To, że takie współdziałanie istnieje, jest sprawą bezsporną. Przecież już najwcześniejsza teologia (Ireneusz, Orygenes) postrzegała współdziałanie Maryi jako zasadnicze, głęboko sięgające i włączone w pośrednictwo całego Kościoła. Jednakże dopiero od średniowiecza teologia zajęła się gruntowniej funkcją pośrednictwa

\footnotetext{
1 Por. D. Mastalska, Maryja w tajemnicy zbawienia, Licheń Stary 2012, s. 340.

2 Por. J. Lekan, Chrystologiczny wymiar „via pulchritudinis” w mariologii, SM 15 (2013) nr 1-4, s. 31-47.
} 
Najświętszej Maryi Panny. Jak zatem dziś rozumieć rolę pośrednictwa Maryi w dynamicznych dziejach zbawienia? ${ }^{3}$

\subsection{Współdziałanie}

Wychodząc jedynie od tajemnicy wcielenia jako zbawczego działania Boga w Jego Synu, można już dostrzec współdziałanie Maryi. Jej znaczenie w dziele zbawczym ujawnia apostoł Paweł w Liście do Galatów, gdzie czytamy, iż Bóg zsyła Syna swego „zrodzonego z niewiasty” (Ga 4, 5), co jest przecież istotnym momentem w całym działaniu zbawczym Chrystusa, „aby wykupił tych, którzy podlegali Prawu, abyśmy mogli otrzymać przybrane synostwo" (Ga 4, 5).

Słusznie zauważa prof. Anton Ziegenaus, że o ile współdziałanie Maryi nie podlega żadnej dyskusji, tak sposób i stopień Jej udziału jest kwestią sporną. Według niemieckiego teologa należy tu unikać dwóch skrajności. Z jednej strony zaangażowanie Maryi nie może w żaden sposób ograniczać i przesłaniać zbawczego dzieła Jezusa Chrystusa jako jedynego Odkupiciela, gdyż jedynie On jest „zmartwychwstaniem i życiem” (J 11, 25) oraz „drogą i prawdą, i życiem" (J 14,6). Nie istnieje żadne odkupienie bez Niego ani poza Nim, tzn. bez Jego człowieczeństwa czy też bez Jego wcielenia. „Albowiem jeden jest Bóg, jeden też pośrednik między Bogiem a ludźmi, człowiek, Chrystus Jezus, który wydał siebie samego na okup za wszystkich jako świadectwo we właściwym czasie" (1 Tm 2, 5) ${ }^{4}$. Z drugiej natomiast strony nie wolno w żaden sposób wykluczać współdziałania stworzenia w dziele odkupienia, które jest i ma pozostać jedynie dziełem Chrystusa. Takie bowiem podejście zaprzeczałoby ludzkiej naturze Odkupiciela lub ją deprecjonowało. Mielibyśmy zatem do czynienia z formą doketyzmu jak w gnozie i u marcjonitów 5 .

3 Por. G. Greshake, Maria - Ecclesia..., dz. cyt., s. 467-489.

4 Por. A. Ziegenaus, Maria in der Heilsgeschichte. Mariologie, [w:] Katholische Dogmatik, Bd. v, Hrsg. L. Scheffczyk, A. Ziegenaus, Aachen 1998, s. 332.

5 Ich założyciel, Marcjon z Synopy, ok. 145 r. głosił rozdział Jezusa od Boga Starego Testamentu. Marcjonici, podobnie jak inni gnostycy, uznawali Jahwe za Boga niebędącego Bogiem kochającym, lecz surowym i „sprawiedliwym”. Twierdzili, że jest On jedynie pomniejszym bogiem, Demiurgiem. Uznawali judaizm za „religię tego świata”, odrzucając jego związek z chrześcijaństwem. Twierdzili, że Jezus był wysłannikiem Najwyższego Boga (Boga Miłości, Boga Światła), nie zaś żydowskim Mesjaszem. Zaprzeczali również narodzeniu Jezusa z Maryi. 
Należy zauważyć, że także reformacyjna teologia dość pesymistycznie postrzega możliwość współdziałania ze strony stworzenia. Wprawdzie Marcin Luter wysławiał Maryję, lecz tylko dlatego, że akcentowała Ona swoją nicość i Bożą łaskawość. W swoim Komentarzu do Magnificat podkreślał, iż Maryja nade wszystko wielbi wielkość, świętość, miłosierdzie Jahwe, a sama określa się jako uniżona, pełna bojaźni służebnica Pańska (ancilla Domini) ${ }^{6}$. Ojciec reformacji przyrównywał wielkość Maryi do materialności poprzecznej belki krzyża: jest ona całkowicie bierna. Zadziwiające, że Maryja zawsze prezentowana jest jako przeciwieństwo Boga: lepiej uczynić szkodę Jej niż Bogu, lepiej stracić Ją niż Boga. Podobnie jest u kalwińskiego teologa ze Szwajcarii, Karla Bartha (1886-1968), który akceptuje Maryję jedynie z powodu Jej pasywności. Z katolickiego punktu widzenia pogląd taki jest nie do utrzymania, gdyż cielesność Chrystusa, a tym samym macierzyństwo Maryi, są aktywnymi elementami w wydarzeniu odkupienia. Matka Jezusa nie jest żadnym martwym narzędziem odkupienia, lecz odsłania swoją decyzję w wolnym wyborze (fiat).

Macierzyństwo Maryi - spełniające się w sposób godny i właściwy - domaga się wolnej personalnej akceptacji. Bóg nigdy nie wymusza zbawienia. W Nowym Testamencie Jezus i Maryja nie są ukazywani jako przeciwieństwa. W ujęciu Mateuszowym mamy określenie: „Dziecię i Jego Matka”, a Elżbieta poczuwa się do pozdrowienia przychodzącej do niej Maryi pełnym szacunku zwrotem: „Błogosławiona jesteś między niewiastami i błogosławiony jest owoc Twojego łona" (Łk 1, 42). Przez bliskość z Synem Maria w swoim osobowo przyjętym macierzyństwie jest - co stanowi istotny akcent chrystotypiczny - nawet oddzielona od reszty ludzkości i już czczona jako całkowicie odkupiona. Duch Święty przez Elżbietę daje temu świadectwo: „A skądże mi to, że Matka mojego Pana przychodzi do mnie? [...] Błogosławiona jesteś, któraś uwierzyła, że spełnią się słowa powiedziane Ci od Pana" (Łk 1, 44a. 45). Łaska sprowadzona przez Chrystusa uzdalnia Maryję do współdziałania. Cała Jej działalność opiera się na darze,

Ich doktryna opisywała więc dwóch Bogów, istniejących obok siebie i niezależnie od siebie „sprawiedliwego” Boga Izraela i „dobrego” Boga Ewangelii. Były to jako istoty sobie przeciwstawne, aczkolwiek niewalczące ze sobą.

Zob. M. Luter, Komentarz do Magnificat, [w:] Teksty o Matce Bożej. Chrześcijaństwo ewangelickie, wstęp, wybór i oprac. S. C. Napiórkowski, przeł. E. Adamik i in., Niepokalanów 2000 (Beatam Me Dicent, 10); zob. K. Kowalik, Wejrzał na nicość swojej stużebnicy. Teologiczno-ekumeniczne studium Komentarza Dr. Lutra do Magnificat, Lublin 1995 (Jeden Pan, Jedna Wiara). 
który został Jej udzielony i wyzwolił Jej własne siły, dlatego wolno mówić o własnym wkładzie Maryi

\subsection{1. Łączność Maryi z Odkupicielem}

Rola Maryi w dziele odkupienia na tle zbawczej solidarności wszystkich ludzi bardzo wcześnie stała się przedmiotem refleksji teologicznej. Już św. Justyn w Dialogu z Żydem Tryfonem podkreślił zbawczą rolę Maryi, przeciwstawiając ją zgubnemu działaniu Ewy. Święty Ireneusz nazywa Maryję, ze względu na Jej posłuszeństwo, „przyczyną zbawienia dla całego rodzaju ludzkiego". Czyni to również w porównaniu Maryji i Ewy w znanym dziele Adversus haereses. Antyteza Ewa - Maryja stała się dla wielu innych ojców Kościoła okazją do wypowiedzi na temat udziału Maryi w dziele odkupienia. W teologii średniowiecza pojawiają się w odniesieniu do Matki Chrystusa tytuły Redemptrix i Coredemptrix.

Soteriologiczne ukierunkowanie nowożytnej mariologii doprowadziło w pierwszej połowie $\mathrm{xx}$ wieku do ożywionej dyskusji na temat tych dwóch tytułów maryjnych, wskazujących na znaczenie i rolę Matki Chrystusa w dziele odkupienia. Z przekonania, że Maryja swoje fiat, będące początkiem dzieła zbawienia na ziemi, wypowiedziała w imieniu całej ludzkości, wywodzi się przyznawany Maryi tytuł Pośredniczki - Mediatrix. Biblijna scena pod krzyżem jest punktem wyjścia rozważań na temat współcierpienia Maryi i jednocześnie Jej udziału w dokonanym wówczas odkupieniu. Stąd wywodzi się tytuł Współodkupicielki dla Maryi - Coredemptrix. Oba określenia znalazły się w rozmaitych wypowiedziach papieży, nie mają jednak charakteru dogmatycznego. Starania o dogmatyzację obu tych tytułów podejmowane były zwłaszcza przed Soborem Watykańskim II. Sobór ten nie ogłosił jednak żadnych nowych dogmatów, gdyż w zamierzeniu miał charakter duszpasterski. W swoich wypowiedziach na tematy maryjne Sobór nie używa określenia Współodkupicielka, pośrednictwo zaś Maryi widzi w kontekście wypowiedzi Pisma Świętego o jedynym pośrednictwie Jezusa Chrystusa (por. 1 Tm 2, 5). Jakkolwiek sam tytuł Coredemptrix nie występuje w nowszych wypowiedziach papieży i jest kwestionowany przez teologów, to jednak sam fakt współdziałania Maryi w dziele odkupienia jest elementem powszechnego nauczania w Kościele.

7 Por. A. Ziegenaus, Maria in der Heilsgeschichte. Mariologie, dz. cyt., s. 333. 


\subsubsection{Odkupienie i udział Maryi}

Punktem wyjścia teologicznych rozważań na temat udziału Maryi w odkupieńczym dziele Chrystusa winien być namysł nad ogólnym sensem pojęcia „odkupienie”. Ten centralny termin teologii chrześcijańskiej był przedmiotem rozmaitych interpretacji w historii teologii i nadal wymaga dyskusji i pogłębionej refleksji. Teologia patrystyczna rozumiała odkupienie jako przeprowadzony przez Boga w Chrystusie wielki proces pedagogiczny, w którym natura ludzka otwiera się na zbawienie. Myśl średniowieczna podkreślała w dziele zbawienia raczej przywrócenie pierwotnego porządku świata, zakłóconego i odwróconego przez grzech. Można więc powiedzieć, że patrystyczne rozumienie odkupienia charakteryzowało się dynamizmem, średniowieczne zaś było raczej statyczne i zwrócone ku przeszłości.

W warunkach przywróconego - przez ofiarę krzyżową Chrystusa - porządku świata jednostka może dążyć do zbawienia. To, co istotne, już się dokonało, chodzi tylko o to, aby pojedynczy człowiek miał udział w owocach odkupienia. W związku z tym powstał niezbyt szczęśliwy podział na odkupienie obiektywne i subiektywne. Odkupienie obiektywne to fakt wysłużenia łask przez Chrystusa, odkupienie zaś subiektywne jest „przyswojeniem” odkupienia przez poszczególnych ludzi i polega na zdobywaniu i powiększaniu życia łaski. Ten model cechuje się zbytnim indywidualizmem i przemilcza trynitarny charakter dzieła odkupienia, nic doceniając zwłaszcza roli Ducha Świętego.

Dla głębszego zrozumienia istoty udziału Maryi w dziele odkupienia ważne jest rozważenie również jego społecznego charakteru. Bóg darzy człowieka zbawieniem nie jako jednostkę, ale jako członka społeczności Ludu Bożego. Lud Boży odgrywa w procesie odkupienia aktywną rolę, gdyż Bóg uwzględnia wolność człowieka. Poszczególni członkowie wspólnoty Ludu Bożego są ze sobą powiązani. Jeden ma wpływ na zbawienie drugiego. Wskazuje na to np. rola proroków w dziejach narodu wybranego, a przede wszystkim zbawczy czyn Jezusa Chrystusa, który stał się Odkupicielem wszystkich ludzi i chciał, aby dzieło Jego zbawienia było dalej udzielane w Kościele.

Należy pamiętać, że odkupienie jest pojęciem, które w teologii od samego początku zarezerwowano dla dzieła dokonanego przez Boga w Jezusie Chrystusie. Chodzi o dzieło uwolnienia człowieka z jego uwikłania się w grzech i odnowienie zapoczątkowanego w stworzeniu przymierza człowieka z Bogiem oraz nadanie mu trwałego i wiecznego charakteru. Jest to działanie Trójcy Przenajświętszej, spełniane przez Ojca, który posyła na świat Syna, 
i przez Ducha Świętego działającego w Kościele. Tajemnica Bożego działania nic wyklucza jednak aktywności człowieka. Teologia scholastyczna ze swoją zdolnością do rozróżniania powie, że przyczyna pierwsza nie tylko nie wyklucza przyczyn drugorzędnych, lecz także sprawia, że działają. Ten pozorny paradoks w odniesieniu do odkupienia formułuje List do Filipian: „Zabiegajcie o własne zbawienie z bojaźnią i drżeniem [...], albowiem to Bóg jest w was sprawcą i chcenia, i działania zgodnie z Jego wolą" (Flp 2, 12-13). To prawo dotyczy Maryi w o wiele większym stopniu niż każdego innego człowieka ze względu na Jej rolę Matki Odkupiciela i wiernej Towarzyszki Jego zbawczego cierpienia.

\subsubsection{Dowodzenie teologiczne}

W argumentacji teologicznej szczególną rolę odgrywa mariologia czwartej Ewangelii - podkreślana przez Jana obecność Niewiasty w decydujących momentach godziny Jezusa, zwłaszcza w scenie pod krzyżem (J 19, 25-27). Jest to kulminacyjna chwila życia Jezusa i życia Maryi. Godzina Jezusa łączy się wówczas z godziną Maryi. W tym kontekście zwrot „Niewiasto”, jakim Jezus obdarza Maryję, nawiązuje do pierwszej niewiasty, Ewy, i - jak pisze papież Jan Paweł II w encyklice Redemptoris Mater - sięga głębi tajemnicy Maryi i dotyka Jej szczególnego miejsca w całej ekonomii zbawienia ${ }^{8}$. Ta sama encyklika upatruje w Maryi czynnika decydującego o współuczestnictwie w zbawczym cierpieniu Jezusa. Mówiąc o wyniszczeniu (kenozie) Chrystusa, papież pisze, że „Maryja uczestniczy przez wiarę we wstrząsającej tajemnicy tego wyniszczenia. Jest to chyba najgłębsza w dziejach człowieka «kenoza wiary». Przez wiarę Matka uczestniczy w śmierci Syna, a jest to śmierć odkupieńcza".

Istoty współdziałania Maryi upatrują teologowie w Jej przyzwoleniu, w Jej fiat. Przy zwiastowaniu jest to zgoda na życie, zaś pod krzyżem jest to zgoda na śmierć. Maryja uczestniczy w ofierze krzyża niejako w imieniu wszystkich ludzi, wyraża włączenie społeczności Kościoła w ofiarę Zbawiciela. Jej obecność nie jest konieczna dla dokonania dzieła zbawienia, ale dopełnia harmonii dzieła odkupienia. Można tę obecność porównać do roli obecności wiernych podczas Eucharystii. Udział Maryi w dziele zbawienia nie jest wkładem, który coś uzupełnia lub dodaje do odkupieńczego działania Chrystusa.

\footnotetext{
RM 24.
}

9 RM 18. 
O współpracy Maryi w dziele odkupienia mówi punkt 61 konstytucji Lumen gentium, podkreślając, że była Ona Matką - Żywicielką Boskiego Odkupiciela.

Błogosławiona Dziewica, przeznaczona od wieków razem z wcieleniem Słowa Bożego na Matkę Boga, stała się tu, na ziemi, z postanowienia Opatrzności Bożej, Matką Żywicielką Boskiego Odkupiciela, w sposób szczególny przed innymi szlachetną towarzyszką i pokorną służebnicą Pana. Poczynając, rodząc i karmiąc Chrystusa, ofiarowując Go w świątyni Ojcu i współcierpiąc ze swoim Synem umierającym na krzyżu, w całkiem szczególny sposób współpracowała w dziele Zbawiciela przez posłuszeństwo, wiarę, nadzieję i żarliwą miłość żarliwą dla odnowienia nadprzyrodzonego życia dusz ludzkich. Dlatego stała się nam matką $\mathrm{w}$ porządku łaski ${ }^{10}$.

\subsection{Pośrednictwo}

Fakt uczestnictwa Najświętszej Maryi Panny w dokonanym przez Chrystusa dziele odkupienia jest fundamentem i źródłem - jak to zresztą wynika z poprzedzających refleksji - nauki o pośrednictwie Maryi. Problem pośrednictwa należy do tych zagadnień, które rzutują na całość teologicznego myślenia o misji Maryi w historii zbawienia. Łączy bowiem w sobie zarówno tematy chrystologiczne, jak i eklezjologiczne oraz obejmuje zagadnienia trynitarne, soteriologiczne, pneumatologiczne i antropologiczne.

\subsubsection{Stanowisko Magisterium}

W nauczaniu Magisterium Kościoła najdoskonalszym Pośrednikiem jest Chrystus. To On dokonał dzieła zbawienia, przywracając zerwaną przez grzech łączność między Bogiem a człowiekiem. W pośrednictwie Chrystusa można wyróżnić niejako trzy etapy. Pierwszym z nich jest w ci e le n i e. Syn Boży stał się człowiekiem i w jednej Osobie połączył dwie rzeczywistości: Boga i człowieka. Drugi etap to Jego męka, śmierć i zmartwychws t a n i e, przez które dokonało się pojednanie człowieka z Bogiem; trzeci to aktualizacja odkupienia, dokonująca się stale przez wieki dzięki s a kramentom Kościoła.

${ }^{10}$ Por. S. Budzik, Maryja w tajemnicy Chrystusa i Kościoła, dz. cyt., s. 112-118. 
Maryja odgrywa szczególną rolę w każdym z tych etapów. Pismo Święte ukazuje Jej niezwykłą rolę w tajemnicy wcielenia jako Matki Chrystusa, świadczy o Jej obecności w czasie ofiary krzyżowej i podczas narodzin Kościoła, w którym Chrystus chciał kontynuować dzieło odkupienia. Wiele tekstów ewangelicznych sugeruje pośredniczącą aktywność Maryi. To na głos Jej pozdrowienia uświęcenia doznał w łonie swej matki Elżbiety Jan Chrzciciel, ostatni prorok Starego Przymierza i zwiastun Nowego, a Elżbieta napełniona została Duchem Świętym (por. Łk 1, 40-45). To Ona pełni funkcję Pośredniczki między Jezusem a gospodarzami wesela w Kanie Galilejskiej. Na Jej prośbę Jezus uczynił początek znaków (J 2, 1-11). Maryja była również obecna w Wieczerniku, kiedy Chrystus zesłał na reprezentantów młodego Kościoła całą obfitość darów Boskiego Ducha.

Tradycja Kościoła od najwcześniejszych wieków uznawała rolę Maryi jako Pośredniczki. Świadczą o tym zanoszone do Niej modlitwy, jak choćby Pod Twoją obronę czy inne liczne modlitwy i wezwania starożytnego Kościoła.

Po raz pierwszy tytuł Pośredniczki nadaje Maryi św. Efrem Syryjczyk, nazywając Ją Pośredniczką całego świata. Odtąd mnożą się wypowiedzi ojców Kościoła i teologów na ten temat. Należą do nich św. German, patriarcha Konstantynopola, św. Bernard z Clairvaux, św. Bernardyn ze Sieny, św. Ludwik Maria Grignion de Montfort, św. Alfons Liguori. Tytuł Pośredniczki znajduje się również w licznych wypowiedziach maryjnych papieży ostatniego stulecia. Konstytucja soborowa Lumen gentium mówi na ten temat:

Dlatego to do Błogosławionej Dziewicy stosuje się w Kościele tytuły: Orędowniczki, Wspomożycielki, Pomocnicy, Pośredniczki. Rozumie się jednak te tytuły w taki sposób, że niczego nie ujmują one ani nie przydają godności i skuteczności działania Chrystusa, jedynego Pośrednika ${ }^{11}$.

$\mathrm{Z}$ jednej strony Maryja znajduje się wśród ludzi. Jako stworzenie jest tylko człowiekiem, a wszystkie Jej przywileje wynikają z zasług Chrystusa. Z drugiej strony należy do Chrystusa zmartwychwstałego i uwielbionego. Z teologii Listów Pawłowych wynika, że związek każdego chrześcijanina z Chrystusem wprowadza go do chwały zmartwychwstania. Chwała jedynego i unikalnego pośrednictwa Jezusowego zostaje przekazana członkom Jego Mistycznego Ciała w myśl obietnicy zapisanej u św. Jana: „I także chwałę, którą mi dałeś, przekazałem im" (J 17, 22). Zostaje ona im przekazana

${ }^{11}$ KK 62. 
proporcjonalnie do więzi, jaka łączy ich z Chrystusem. W wypadku Maryi jest to więź jedyna i nieporównywalna z żadną inną ludzką relacją. Maryja jest z Nim złączona całkowicie - tak, że żaden aspekt Jego pośrednictwa nie jest Jej obcy. Porównując mariologię przedsoborową $\mathrm{z}$ soborową oraz z aktualnie uprawianą, wyraźnie dostrzegamy różnicę w zakresie maryjnego pośrednictwa. Wolno mówić o różnicach istotnych: tak formalnych, jak i treściowych. Przede wszystkim widać ewolucyjne przechodzenie od ujmowania maryjnego pośrednictwa rozumianego jako pośrednictwo „do" w kierunku pośrednictwa „w”"

\subsubsection{Nowe modele pośrednictwa}

$\mathrm{W}$ mariologii posoborowej pojawiły się głosy sugerujące potrzebę pogłębienia teologii pośrednictwa Maryi. Krytykowano tradycyjny, „piętrowy” model pośrednictwa: my zwracamy się do Maryi, Maryja wstawia się za nami u Chrystusa, a Chrystus prosi Ojca. Z kolei Ojciec daje Synowi, Syn przekazuje Maryi, Maryja zaś rozdaje nam. W modelu tym nie ma miejsca na bezpośredni kontakt człowieka wierzącego z Chrystusem. Pośrednictwo Maryi ukazane jest w sposób daleki od doskonałości, skoro nie łączy bezpośrednio Chrystusa i wierzących. Doskonałym pośrednikiem jest bowiem ten, kto nie staje między poróżnionymi stronami, ale doprowadza do pełnej zgody i miłości między nimi. Mediatio jest doskonała wtedy, gdy prowadzi do bezpośrednich relacji (immediatio).

Aby właściwie zrozumieć pośrednictwo Maryi, należy je ustawić nie obok pośrednictwa Chrystusowego, co prowadzi nieuchronnie do myślenia „konkurencyjnego”, lecz w jedynym pośrednictwie Chrystusa. Można wprawdzie mówić, że Maryja jest Pośredniczką u Pośrednika, ale lepiej jest mówić, że jest Pośredniczką w Pośredniku i za Jego pośred$\mathrm{n}$ ictwe m. A więc pośrednictwo Maryi rozumiane jest jako uczestnictwo w jedynym, doskonałym pośrednictwie Chrystusa.

Pośrednictwo Maryi jest podporządkowane pośrednictwu Chrystusa i całkowicie od niego zależne. Między Jezusem a Jego Matką panuje tak doskonała harmonia, że Maryja pragnie czynić tylko to, co jest zamiarem Chrystusa. Przedstawianie Maryi jako Matki Miłosierdzia w przeciwstawieniu do Boga kierującego się „tylko” sprawiedliwością („Lecz kiedy Ojciec rozgniewany siecze, szczęśliwy, kto się do Matki uciecze", jak głoszą słowa jednej z pieśni) jest nieporozumieniem i błędem teologicznym.

${ }^{12}$ Por. W. Siwak, Ku pośrednictwu w Chrystusie, sM 16 (2014) nr 1-4, s. 37-53. 
Oprócz powyższego modelu pośrednictwa, który można określić jako chrystologiczny, istnieje model antropologiczny, wyrażający się w formule "pośrednictwo przez ludzi” (mediatio per homines). Jego autorem jest Karl Rahner, który w swoich rozważaniach wychodzi od faktu radykalnej wzajemnej współzależności ludzi we wszystkich dziedzinach, również w dziedzinie zbawienia. Zbawienie człowieka dokonuje się w relacjach społecznych, ma charakter międzyosobowy: „Bóg oczekuje nas nie w górze, ponad człowiekiem, ale na horyzoncie, gdzie żyją ludzie, czyli ukrywa się w człowieku; z drugiej zaś strony nasze horyzontalne odniesienie do ludzi rozstrzyga o zbawieniu, czyli o naszym stosunku do Boga, jest więc wertykalne"13.

Historia zbawienia każdego człowieka spleciona jest $\mathrm{z}$ historią zbawienia innych ludzi, zależy od niej i wywiera na nią wpływ. Można więc mówić o wzajemnym pośredniczeniu w przekazywaniu zbawienia. Rahner posługuje się obrazem wielkiej sieci rybackiej. Każdy jej węzeł to człowiek, złączony ściśle z innymi ludźmi; razem tworzą one sieć Kościoła. Chrystus jest Rybakiem, który ciągnie sieć na brzeg historii. Do portu zbawienia mają szansę dotrzeć tylko ci, którzy znajdują się w strukturze sieci. Solidarność międzyludzka jest więc niezbędnym elementem zbawienia, choć sama w sobie nie jest źródłem ratunku. Jedynie Chrystus jest władny doprowadzić wszystkich do brzegu czy portu zbawienia. Tak rozumiane pośrednictwo ludzkie jako „zbawcze udzielanie się wszystkich wszystkim”14 nie jest konkurencyjne w stosunku do jedynego pośrednictwa Chrystusa. W sieci tego międzyludzkiego pośrednictwa ważną rolę odgrywają święci i błogosławieni, a wśród nich szczególne miejsce przysługuje Najświętszej Maryi Pannie.

W dziełach Heriberta Mühlena i Yves’a Congara znaleźć można model pośrednictwa Maryi in Spiritu Sancto - „pośrednictwa w Duchu Świętym”. Maryja jest Pośredniczką, gdyż uczestniczy w uświęcającym działaniu Ducha Świętego. Zagadnienie to wiąże się z formułowaną coraz częściej potrzebą pogłębienia nauki o Duchu Świętym, którego rola w doktrynie Kościoła katolickiego jest zdaniem wielu teologów zbyt mało wyeksponowana. W czasie obrad Soboru Watykańskiego II ojcowie i obserwatorzy reprezentujący chrześcijaństwo wschodnie zwrócili uwagę na brak wzmianki o Duchu Świętym w początkowych dokumentach soborowych. Pod wpływem tych

\footnotetext{
${ }_{13}$ Por. I. Bokwa, Wprowadzenie do teologii Karla Rahnera, Tarnów 1996, s. 18onn.

${ }^{14}$ Por. tamże.
} 
uwag nastąpiło pogłębienie refleksji nad dynamiczną obecnością Ducha Świętego w Kościele tak w czasie Soboru, jak i w teologii posoborowej ${ }^{15}$.

Zdaniem H. Mühlena nie da się prawidłowo zrozumieć pośrednictwa Maryi bez rozważenia tajemnicy zbawczego posłannictwa Ducha Świętego i Jego roli w Kościele. Duch Święty bezpośrednio przekazuje nas Jezusowi: jeżeli On mieszka w nas, nie potrzeba już dalszego kroku, gdyż już jesteśmy w Chrystusie, a przez to w jedności z Ojcem - ten, kto widzi Jezusa, widzi i Ojca (por. J 14, 9). Ducha Świętego nie nazywamy Pośrednikiem, gdyż jest On samym Pośrednictwem.

Maryja znajduje się według Mühlena w szczególnej zależności od Ducha Świętego. To Jego mocą staje się Ona Matką Syna Bożego i dzięki Jego działaniu ma udział w dziele zbawienia. Jej współpraca jest przede wszystkim uczestnictwem w zbawczym współdziałaniu Ducha Świętego z odkupieńczym dziełem Jezusa. Misja Maryi w dziele zbawienia zależy więc całkowicie od Ducha Świętego. Zanim możemy zwrócić się do Maryi, musi już działać w nas Duch Święty. „Maryja w całości swej tajemnicy jest darem Ducha. Dzięki Duchowi i w Duchu prowadzi nas do Chrystusa, dzięki Duchowi jest w jedności z nami i wyjednuje Go dla nas, gdy pod wpływem Ducha zwracamy się do Niej o pośrednictwo" ${ }^{16}$.

Również św. Maksymilian Maria Kolbe rozwija w swych dziełach naukę o pośrednictwie Maryi w Duchu Świętym. Obok tradycyjnego modelu „pośrednictwa piętrowego”, a nawet przeciwstawiania sprawiedliwości Bożej miłosierdziu Maryi można odnaleźć w późniejszych pismach tego świętego nowy, pogłębiony model pośrednictwa. Przedmiotem refleksji teologicznej o. Maksymiliana staje się tajemnica niepokalanego poczęcia ze szczególnym podkreśleniem roli Ducha Świętego. Niepokalane poczęcie rozumiane pozytywnie to pełnia świętości i dobra w znaczeniu osobowym, czyli pełnia Ducha Świętego. Duch Święty zjednoczył się z Maryją i uczynił Ją narzędziem swojej pośrednicząco-uświęcającej aktywności ${ }^{17}$.

${ }^{15}$ Wychodząc naprzeciw tym skądinąd słusznym postulatom, w niniejszej książce zamieszczono rozdział poświęcony elementom pneumatologicznym mariologii, które ukazują jedność Maryi z Duchem Świętym jako podstawę Jej istnienia i działania w dziele zbawienia.

${ }_{16}$ Por. J. Kudasiewicz, Matka Odkupiciela, Kielce 1991, s. 194 (Maryja w Dziejach Zbawienia, 1).

${ }_{17}$ Por. G. Bartosik, Myśl maryjna św. Maksymiliana Marii Kolbego, [w:] „Złota nić” niepokalanego poczęcia w myśli i w życiu bł.Jana Dunsa Szkota i św. Maksymiliana Marii Kolbego, red. nauk. G. M. Bartosik, P. Warchoł, Niepokalanów 2015, s. 205-234 (Bibliotheca Kolbiana. Monografie, 1). 
Nowe impulsy dla katolickiej teologii pośrednictwa znajdują się w encyklice św. Jana Pawła II Redemptoris Mater. Papież łączy naukę o pośrednictwie Maryi z nauką o Boskim macierzyństwie. Trzecia część encykliki nosi znamienny tytuł: Pośrednictwo macierzyńskie. Jan Paweł II powtarza wielokrotnie, że specyficzną cechą pośrednictwa Maryi jest Jej macierzyństwo w stosunku do Jezusa Chrystusa, jedynego Pośrednika. Macierzyństwo to papież rozważa w perspektywie historiozbawczej i personalistycznie. Maryja uczestniczyła w zbawczych misteriach Chrystusa. Z tego też powodu jest naszą Matką w porządku łaski.

Fundamentem papieskich rozważań jest nauka Soboru Watykańskiego II, który wyraźnie przypomina biblijną prawdę, że jedynym Pośrednikiem zbawienia jest Jezus Chrystus. Wszelkie pośrednictwo stworzenia jest zakotwiczone $\mathrm{w}$ tym jedynym pośrednictwie i czerpie $\mathrm{z}$ niego swoją moc. Encyklika przypomina aktualność tradycyjnej zasady „przez Maryję do Jezusa”. Mówi ona, że do Syna najlepiej dotrzeć przez Matkę. Łączność Maryi z Chrystusem jest tak nierozerwalna, że poznając Matkę, wzywając Ją i modląc się do Niej, pogłębiamy równocześnie naszą wiarę i miłość do Chrystusa. Ta tradycyjna zasada domaga się jednak uzupełnienia przez drugą zasadę: „przez Jezusa do Maryi”. Chodzi o dążenie do zrozumienia roli Maryi w Bożym planie zbawienia przez kontemplację tajemnic Chrystusa oraz rozważanie posłannictwa Maryi w świetle Słowa, które stało się Człowiekiem.

Z kart papieskiej encykliki wyczytujemy jeszcze inny model pośrednictwa, a mianowicie pośrednictwo przykładu. Rola osobowego wzorca w kształtowaniu ludzkich postaw nie ulega wątpliwości i podkreślana jest również przez dokumenty Kościoła. Rozdział vin konstytucji o Kościele Lumen gentium wskazuje na Maryję jako wzór i przykład życia chrześcijańskiego. Matka Chrystusa jako figura Kościoła przyczynia się do tego, że Kościół przybliża się do Chrystusa i „staje się bardziej podobny do swego wzniosłego pierwowzoru, postępując ustawicznie w wierze, nadziei i miłości oraz szukając we wszystkim woli Bożej i będąc jej posłusznym" ${ }^{\text {"18 }}$. Na związek przykładu z funkcją zbawczego pośrednictwa wskazuje wielokrotnie autor encykliki Redemptoris Mater. Papież dostrzega w Maryi początek Kościoła, podkreśla Jej przodującą funkcję w wierze, ukazuje Ją jako najdoskonalszą Uczennicę Chrystusa. Jej wzorcza obecność promieniuje na cały Kościół pielgrzymujący, dla którego Matka Chrystusa jest drogowskazem. „Maryja

${ }^{18}$ KK 65. 
jako przykład chrześcijańskiego życia, ukazana w encyklice każdemu chrześcijaninowi i całemu Kościołowi, przyczynia się skutecznie do pogłębienia bezpośredniej łączności z Chrystusem, pobudzając i zachęcając do wzrastania w świętości”"19.

\subsection{Macierzyństwo duchowe}

Miejsce i misja Świętej Dziewicy jako Pośredniczki i Współpracownicy w dziele zbawienia, dokonującym się przez posługę Kościoła, określane bywają jako macierzyństwo duchowe. Chodzi tu o teologiczną refleksję nad najbardziej powszechnym aspektem kultu Maryi, która od wieków jest czczona nie tylko jako Matka Chrystusa i Matka Boga, lecz także przede wszystkim jako Matka wszystkich wierzących, która wstawia się za nimi u swego Syna.

Maryja jest Matką Jezusa Chrystusa w sensie dosłownym, biologicznym. Jest również Jego Matką w sensie duchowym, jako Ta, która przekazała $\mathrm{Mu}$ wiarę i matczyną troską otaczała Jego rozwój duchowy. Ponieważ zarówno Bóstwo, jak i człowieczeństwo Chrystusa włączone są w Jego zbawczą misję, można mówić o macierzyńskiej roli Maryi względem zbawczego dzieła Chrystusa i względem wszystkich przez Niego odkupionych. Dlatego też Maryja nazywana jest przez Sobór Matką w porządku łaski.

Podstawą skrypturystyczną nauki o macierzyństwie duchowym Maryi jest scena pod krzyżem opisana przez autora czwartej Ewangelii (J 19, 25-27). Zdaniem wielu egzegetów w opisie oddania ucznia pod opiekę Matki chodzi nie tyle o gest synowskiej troski Jezusa, co o czyn o charakterze teologicznym. W osobie Jana byli reprezentowani pod krzyżem wszyscy wierzący i Maryja stała się w tym momencie ich Matką.

Perykopa J 19, 25-27 jest również biblijnym fundamentem tytułu Matki Kościoła, który przyznał Maryi papież Paweł vi. To teologiczne znaczenie perykopy dostrzeżono dopiero w wieku Ix. Znany ze swych maryjnych homilii Jerzy z Nikomedii (ok. 256-303) jest pierwszym teologiem, który ideę męczeństwa duchowego wywodzi ze sceny pod krzyżem. W Kościele zachodnim należy wspomnieć św. Ruperta z Deutz (ok. 1070-1130), najlepszego średniowiecznego komentatora Ewangelii św. Jana. W swoim komentarzu mówi on o podwójnym zrodzeniu Jezusa przez Maryję, radosnym

${ }^{19}$ G. Bartosik, Myśl maryjna św. Maksymiliana Marii Kolbego, dz. cyt., s. 205-234. 
narodzeniu w Betlejem i powtórnym, wśród cierpienia pod krzyżem. Słowa "Oto Matka twoja" skierowane były do wszystkich ludzi odkupionych śmiercią Chrystusową. Hugo od św. Wiktora (1096-1141) wyjaśnia zaś: „Z tego zdania, w którym powiedziano: Oto Matka Twoja - wynika, że Błogosławiona Dziewica nie tylko została dana za Matkę Janowi, lecz całemu Kościołowi i wszystkim grzesznikom została wskazana jako Matka"2o.

O macierzyństwie powszechnym Maryi mówią liczne dokumenty Kościoła, zwłaszcza wypowiedzi papieży ostatniego stulecia. Konstytucja soborowa Lumen gentium podkreśla, że Maryja stała się nam Matką w porządku łaski: „To macierzyństwo Maryi w ekonomii łaski trwa nieustannie - poczynając od aktu zgody, którą z wiarą wyraziła przy Zwiastowaniu i którą zachowała bez wahania pod krzyżem - aż do wiekuistego dopełnienia się zbawienia wszystkich wybranych"21.

W tym fragmencie wskazane są trzy etapy macierzyńskiego wstawiennictwa Maryi, będące analogią do macierzyństwa fizycznego, które urzeczywistnia się przez poczęcie, zrodzenie i wychowanie dziecka. Pierwszym etapem jest zwiastowanie, podczas którego przez akt zgody Maryi Słowo stało się ciałem i tym samym rozpoczął się proces zbawienia człowieka. Drugi etap to Kalwaria, gdzie powtórzone zostaje i znajduje swój najgłębszy sens fiat wypowiedziane przy tajemnicy wcielenia. Trzeci etap to troska Maryi o urzeczywistnianie dzieła odkupienia w czasie Kościoła:

Wzięta do nieba, nie zaprzestała pełnić tej zbawczej roli, lecz poprzez swoje wielorakie wstawiennictwo ustawicznie wyjednuje nam dary wiecznego zbawienia. Dzięki macierzyńskiej miłości opiekuje się braćmi swego Syna, pielgrzymującymi jeszcze i narażonymi na niebezpieczeństwa i trudy, dopóki nie zostaną doprowadzeni do szczęśliwej ojczyzny"22.

\subsection{Maryja a Kościół}

Relacja Maryi do Kościoła była tematem refleksji teologicznej już w pierwszych wiekach. W czasach najnowszych tematyka ta stała się szczególnie aktualna wskutek rozwoju nauk biblijnych, które ujawniły nowe aspekty

\footnotetext{
${ }^{20}$ Por. tamże, s. 194-195.

${ }^{21}$ KK 62.

${ }^{22}$ кк 62. Por. S. Budzik, Maryja w tajemnicy Chrystusa i Kościoła, dz. cyt., s. 118-129.
} 
mariologii Ewangelistów, a zwłaszcza Łukasza i Jana. Również soborowa konstytucja Lumen gentium zajmuje się obszernie odniesieniem Maryi do Kościoła. To zagadnienie zostało usystematyzowane w trzech kategoriach: członkostwa, typu i macierzyństwa.

Maryja pomaga nam odkrywać piękno Kościoła. Zarówno Jej zewnętrzne piękno, jak i wewnętrzna kultura duchowa znajdują swoje odbicie w Kościele. Pośród licznych przejawów brzydoty, z którą musimy się zmagać w codzienności, Matka Chrystusa otwiera nam oczy na piękno, które wypływa z tajemnicy Chrystusowego Kościoła ${ }^{23}$.

Mariologia odłączona od eklezjologii staje się zafałszowana, a tym bardziej cześć do Najświętszej Maryi Panny poza Kościołem nabiera wypaczonych kształtów. W swojej najnowszej monografii G. Greshake wskazuje przede wszystkim na obiektywizację wiary, która dokonuje się w kościelnej przestrzeni i tym samym zapewnia właściwą maryjność. Wiara jest darem i odpowiedzią wolności (fiat). Religijną wiarę Maryi należy rozpatrywać w płaszczyźnie Jej zaślubin z Jahwe. Dzięki temu już sama osoba Maryi staje się przykładem (exemplum) dla wszystkich członków Kościoła, jak wiarę przyjmować, jak zachować swoje człowieczeństwo i jak je rozwijać w relacjach z Bogiem i z innymi ${ }^{24}$.

\subsubsection{Maryja: członek Kościoła}

Mówiąc o Maryi jako członku Kościoła, mamy na myśli Kościół rozumiany jako Lud Boży, zwoływany przez Jahwe w tajemnicy śmierci i zmartwychwstania Jego Syna. Zostaje on odsłonięty i udzielony ludzkości w przyjściu Ducha Świętego. Kościół jako wspólnota bosko-ludzka nie jest jednak ustanowiony tylko dla zbawienia wierzących w Chrystusa, ale jest on narzędziem zbawienia i znakiem dla całego stworzenia. Możemy tu rozważać trzy płaszczyzny odniesień obecności Maryi: w Kościele, ponad Kościołem, przed Kościołem. Przypatrzmy się im dokładnie po kolei.

1. Maryja jest w Kościele. Jak wszyscy wierzący oczekują zbawienia i potrzebują go, tak i Maryja tęskni za Bożą łaską odkupienia. Jest tak bardzo włączona w Lud Boży Nowego Przymierza, że Kościół nie może zrozumieć swego powołania bez odniesienia go do Jezusowej Matki. Byłoby rzeczą

${ }^{23}$ Por. A. Rybicki, Maryja obrazem piękna Kościoła, sm 15 (2013) nr 1-4, s. 78-88. Na ten temat Katedra Eklezjologii UPJPII zorganizowała konferencję, której pokłosiem jest publikacja: M. Chojnacki, J. Morawa, A. Napiórkowski, Piękno Kościoła, Kraków 2014.

${ }^{24}$ Por. G. Greshake, Maria - Ecclesia..., dz. cyt., s. 367-417. 
niewłaściwą wyłączać Najświętszą Maryję Pannę z Kościoła i umieszczać Ją np. między Kościołem a Chrystusem. Maryja należy do Kościoła jako społeczności powołanych do zbawienia, jest jego niezwykłym członkiem.

2. Maryja jest ponad Kości ołe m. Nie znaczy to jednak, że znajduje się poza Kościołem. Odkupiona w sposób najwznioślejszy, przewyższa wszystkich innych członków Mistycznego Ciała Chrystusa i zajmuje w nim miejsce „najwyższe po Chrystusie i nam najbliższe”25. Jest najznamienitszym członkiem wspólnoty Ludu Bożego. Ze względu na zrodzenie Chrystusa i nasze odkupienie Jej zbawienie dokonało się w sposób uprzedni, na mocy przywileju niepokalanego poczęcia.

3. Maryja jest przed Kościołem, gdyż poprzedza go w wierze i w świętości, we współpracy w zbawczym dziele Chrystusa, w Jego cierpieniu i chwale. Została złączona z Kościołem od samego początku jego istnienia, i to do tego stopnia, że uzasadnione jest stwierdzenie o swoistej preegzystencji Kościoła w Maryi albo nawet określenie Jej jako „Kościoła przed Kościołem”26. Zanim Kościół zaistniał w swojej widzialności, Maryja porodziła w wierze i w ciele Jego Założyciela, Syna Bożego, który z Niej przyjął ludzką naturę.

\subsubsection{Maryja jako typ Kościoła}

Przejdźmy teraz do następnej kategorii oddającej relację Maryi i Kościoła. Jest Ona wzorem i przykładem, do którego odtworzenia dąży Kościół. Konstytucja Lumen gentium mówi, że Kościół naśladuje Maryję jako Matkę i Dziewicę. Idzie za przykładem Maryi w dziewictwie, gdy w sposób nieskazitelny dochowuje wierności Chrystusowi i zachowuje dziewiczo nienaruszoną wiarę, nadzieję i miłość. Kościół wzoruje się na Maryi w macierzyństwie, gdyż przez swoje przepowiadanie rodzi do nowego życia „dzieci poczęte z Ducha Świętego i zrodzone z Boga" ${ }^{27}$. I jedno, i drugie macierzyństwo jest dziewicze, bo zależy całkowicie od Boga, a nie od człowieka.

Najświętsza Maryja Panna jest także współcześnie określana jako pierwsza uczennica Chrystusa. To Ona pierwsza przyjęła z wiarą słowo Boże, zachowywała je i rozważała w swoim sercu oraz wypełniała w życiu. Jest więc wzorem dla Kościoła, który w Jej postawie dostrzega zawsze aktualny

\footnotetext{
${ }^{25}$ KK 54.

${ }^{26}$ Por. J. Kumala, Maryja eschatologiczna ikona Kościoła, [w:] Matka Jezusa pośród pielgrzymującego Kościoła, dz. cyt. s. 278.

${ }^{27}$ KK 64.
} 
wzór do naśladowania i z Niej czerpie inspirację do pogłębiania swojej wiary i wierności Chrystusowi. Za przykładem Maryi pokłada całą swoją ufność i nadzieję wyłącznie w swym Panu i Zbawcy.

Matka Chrystusa jest dla Kościoła wzorem najważniejszych cnót, zwłaszcza wiary, nadziei i miłości oraz pełnego posłuszeństwa woli Bożej. W Jej osobie Kościół osiągnął już doskonałość, do której dąży od wieków. Wiara Maryi wyraża się w pełnym ufności fiat wyrażonym przy zwiastowaniu, które jest początkiem bezwzględnego poświęcenia w służbie Chrystusa. Tak jak wiara Abrahama stoi u początku Starego Przymierza, tak wiara Maryi daje początek Nowemu Przymierzu. Zwiastowanie było punktem wyjścia do długiej i trudnej drogi wiary, którą Maryja podążała przez całe życie.

Dzięki swojej niewzruszonej nadziei zajmuje Maryja - jak mówi Sobór „pierwsze miejsce wśród pokornych i ubogich Pana" ${ }^{28}$, którzy z ufnością oczekują zbawienia od Boga i rzeczywiście go dostępują. Przez miłość stała się Ona uczestniczką dzieła zbawienia, przez miłość uczestniczy we wzroście świętości i łaski w Kościele. Dzięki bezwarunkowemu posłuszeństwu woli Bożej przyczyniła się do realizacji Bożego dzieła zbawienia.

Maryja jest wzorem dla tych wszystkich, którzy przez wiarę, nadzieję i miłość starają się zbliżyć i upodobnić do Chrystusa i całym życiem wypełniać Jego wolę. Maryja jest również ikoną eschatologiczną Kościoła, czyli - jak uczą ojcowie Soborowi - znakiem niezawodnej nadziei i pociechy dla pielgrzymującego Ludu Bożego ${ }^{29}$. W Maryi wniebowziętej, uczestniczącej w chwale Chrystusa zmartwychwstałego, Kościól, będąc w drodze, już realizuje dopełnienie swojego powołania. „W tym bezsprzecznie pierwszym członku osiąga swój kres, spoczynek i pełnię"30.

Uważna analiza postaci Maryi jako typu i figury Kościoła musi też prowadzić do wniosku, że oprócz wielu podobieństw istnieją znaczące różnice między Maryją i Kościołem. Nie wolno tych dwóch rzeczywistości ani ujednolicać, ani utożsamiać, gdyż Kościół napotyka wyraźne granice w naśladowaniu Najświętszej Maryi Panny. Przede wszystkim nie wolno zapominać, że Maryja jest (jedną) osobą, a Kościół jest Ludem Bożym. Dlatego przypisywanie całej zbiorowości niektórych przymiotów osoby może się odbywać tylko na zasadzie analogii. Dotyczy to np. macierzyństwa. Maryja bowiem jest Matką Bożą w sensie dosłownym, a Kościół jest matką

\footnotetext{
${ }^{28}$ KK 55.

29 Por. KK 68.

$3^{30}$ R. Laurentin, Matka Pana. Krótki traktat teologii maryjnej, dz. cyt., s. 230.
} 
w sensie metaforycznym. Następna różnica polega na tym, że Maryja jest wzorem Kościoła „w porządku wiary, miłości i doskonałego zjednoczenia z Chrystusem"31 , a Kościół nie jest tylko wspólnotą zbawienia, lecz także strukturą hierarchiczną, instytucją sakramentalną ${ }^{32}$.

\subsubsection{Maryja Matką Kościoła}

Soborowa konstytucja o Kościele nie używa w sposób wyraźny tego tytułu. Mówi jednak, że Maryja jest „Matką członków Chrystusa” i że Kościół katolicki czci Ją jako Matkę najmilsząa $a^{33}$. Stwierdza, że Maryja współdziałała w zrodzeniu wiernych z macierzyńską miłością; Kościół rozmyśla o Maryi z miłością synowską. Dopiero papież Paweł vi w swoim przemówieniu na zakończenie III sesji Soboru, wygłoszonym dnia 21 listopada 1964 roku, uroczyście ogłosił Maryję Matką Kościoła: „Ku chwale więc Najświętszej Maryi Panny oraz ku naszej radości ogłaszamy Najświętszą Maryję Matką Kościoła, czyli całego ludu chrześcijańskiego, zarówno wiernych, jak pasterzy, którzy wszyscy zwą Ją swą Matką najmilszą" ${ }^{34}$.

Przed papieską proklamacją tytuł „Matka Kościoła” był podczas obrad soborowych przedmiotem kontrowersji, mimo że nie było wątpliwości na temat nauki o duchowym macierzyństwie Maryi względem członków Ciała Mistycznego. Część ojców Soboru obawiała się niewłaściwego zrozumienia tego tytułu. Żywiono obawy przed błędnym wyobrażeniem, jakoby Maryja stała ponad Kościołem. Papież w swoim przemówieniu podkreśla więc przynależność Maryi do Kościoła, mówiąc, że jest Ona Matką pasterzy i wiernych.

Podstawą tytułu „Matka Kościoła” jest najpierw sam fakt wcielenia. Maryja jest bowiem Matką Chrystusa, który jest Głową Ciała Mistycznego, którym jest Kościół. Przez swoje współcierpienie pod krzyżem współdziałała w dziele odkupienia i dlatego stała się nam „Matką w porządku łaski”" ${ }^{35}$, jak mówi Sobór. Jan, stojący pod krzyżem i oddany pod macierzyńską opiekę Maryi, jest reprezentantem całego Kościoła. Zaznaczona przez Łukasza obecność Maryi w Wieczerniku sugeruje myśl o uczestnictwie Maryi w narodzinach Kościoła powszechnego. Będąc w chwale niebieskiej, Maryja

31 KK 63.

${ }^{32}$ Por. J. Królikowski, K. Kupiec, Matka Zbawiciela. Mariologia, dz. cyt., s. 141-143.

33 Por. KK 53.

34 Paweł vi, Przemówienie papieża na zakończenie III sesji Soboru Watykańskiego II, 21 listopada 1964 roku, [w:] Gratia plena..., dz. cyt., XviıI.

35 KK 61. 
spełnia swoją funkcję zbawczą poprzez wstawiennictwo macierzyńskie i powszechne.

Tytuł Maryi jako Matki Kościoła uzupełniają i wzbogacają jeszcze dwa inne, a mianowicie „Matka Boga” i „Matka ludzi”. Najświętsza Maryja Panna stała się Matką Boga ze względu na swoje macierzyńskie współdziałanie w dziele zbawczym. Chodzi tu zatem o macierzyństwo rozciągające się na cały Kościół. Natomiast określenie Jej jako Matki ludzi mówi nam, że nie jest ona Matką jednostkowego wierzącego, lecz wszystkich chrześcijan trwających w eklezjalnej wspólnocie ${ }^{36}$.

Problematyka „Maryja a Kościół” została interesująco opracowana także w pismach Hansa Ursa von Balthasara, który łączy mariologię z eklezjologią w tajemnicy oblubieńczości. Ukazując Kościół podmiotowo i osobowo, szwajcarski jezuita opisuje jego centrum, które nie może być nigdy tożsame z Chrystusem. Tak oto Kościół jest oblubienicą Słowa, sponsa verbi. Ale również i Maryję starożytność określała jako sponsa verbi. Jednak pełna realizacja idei oblubieńczości dokonała się w Matce Boga. Ostatecznie głównym celem Maryi i Kościoła jest zjednoczenie się z Chrystusem w Duchu Świętym, gdyż tak Ona, jak i Kościół nie mogą mieć relacji z żadnymi bożkami, dlatego mogą być duchowo płodne $e^{37}$.

${ }^{36}$ Por. S. Budzik, Maryja w tajemnicy Chrystusa i Kościoła, dz. cyt., s. 130-134.

${ }^{37}$ Por. K. Ternka, Maryjne znamię Kościoła w teologii Hansa Ursa von Balthasara, sM 13 (2011) nr 1-2, s. 11-49. 


\section{Celebracja Maryi w Kościele}

Cześć, jaką wspólnota wierzących oddaje Najświętszej Maryi Pannie już od zarania Kościoła, ma nie tylko specyficzną formę, lecz także długą tradycję. Warto zrekonstruować historię tej pobożności, aby przynajmniej zaprezentować przewodnie treści i wątki tego kultu. Ostatecznie stworzy to właściwe podstawy do wykładni aktualnej maryjności, czyli odpowie na pytanie, jak dzisiaj czcić Maryję, która okazuje się Matką nie tylko Chrystusa, lecz także wciąż pielgrzymującego Kościoła. Bez wątpienia należy też odnaleźć odpowiedź na pytanie, dlaczego czcić Najświętszą Maryję Pannę i jak składana Jej cześć ma się do kultu Najwyższego Boga. Trzeba tu pamiętać, że kult Matki Jezusa stanowi integralną część całego kultu chrześcijańskiego, oddawanego Trójjedynemu Bogu w Duchu Świętym, dlatego też nie wolno go ani izolować, ani też deprecjonować.

\subsection{Z dziejów maryjnej pobożności}

Cześć oddawana Maryi towarzyszy Ludowi Bożemu od zarania dziejów Kościoła. Widzi on w rozlicznych przejawach kultu Matki Chrystusa wypełnienie zapowiedzi zwartej w Magnificat: „Oto błogosławić mnie będą odtąd wszystkie pokolenia” (Łk 1, 48). Kult maryjny w ciągu dwóch tysięcy lat chrześcijaństwa przybierał różne formy i nie był przy tym pozbawiony tak pewnych nadużyć, jak i pięknych i głębokich momentów swojego rzeczywistego rozwoju. Już w dziewiętnastym stuleciu J. H. Oswald i M. J. Scheeben słusznie zauważyli, że mariologia bez maryjności staje się nieprzystępna i skostniała. Z kolei maryjność musi być nieustannie poddawana refleksji 
teologicznej i krytycznie analizowana w świetle całej nauki o Najświętszej Maryi Pannie.

Aby trafniej zaprezentować kult przysługujący dzisiaj Najświętszej Maryi Pannie, wyodrębnimy teraz główne prądy z bogatej historii chrześcijańskiej pobożności maryjnej. Chodzi nie tyle o to, abyśmy się przy nich zatrzymali i je głębiej analizowali, ile o ukazanie kompleksowo niekiedy dość interesujących epoki maryjności. Wydaje się, że można mówić o siedmiu takich znaczących nurtach. W kolejności chronologicznej są to: 1. epoka poapostolska i patrystyczna; 2. od soboru efeskiego do połowy średniowiecza, 3. okres między wiekiem XI a XVI; 4. ruchy reformacyjne i Sobór Trydencki; 5. maryjne szkoły duchowości; 6. apogeum kultu maryjnego, 7. Sobór Watykański II i jego reforma maryjna.

\subsubsection{Epoka poapostolska i patrystyczna (I-v wiek)}

Zestawienie historii pobożności maryjnej rozpoczniemy od pierwotnego Kościoła do czasu soboru efeskiego (431) i wprowadzania jego postanowień w życie.

Pierwsze świadectwa czci maryjnej znajdujemy w zapisach biblijnych. Zostały one wyrażone w opisie zwiastowania przez archanioła Gabriela oraz przez Elżbietę, matkę Jana Chrzciciela. Niezwykłą pozycję zajmowała Maryja w popaschalnej społeczności pierwotnego Kościoła, gdzie uczniowie i uczennice Jezusa tworzący pierwsze gminy judeochrześcijańskie otaczali Ją wyjątkową troską i miłością. Matkę Jezusa zaczęto z czasem otaczać kultem, który miał ścisłe odniesienie do Zmartwychwstałego i do kolegium apostolskiego. Pojawiły się pierwsze do Niej modlitwy, jak np. Zdrowaś Maryjo czy też Pod Twoją obronę. Z jej osobą i życiem wiązano pewne miejsca, które uchodziły za loca sacra i zaczęły być nawiedzane przez wierzących.

W 376 roku Grzegorz z Nazjanzu potwierdził zwyczaj zwracania się do Maryi i „uciekania się do Jej wstawiennictwa”. W IV wieku imię Maryi zostało także włączone do kanonu wschodniej liturgii. Jej kult zyskuje u św. Efrema - formę „czci i podziwu”. Z kolei w pismach św. Ambrożego i św. Augustyna kierowana jest do Najświętszej Maryi Panny „ufna modlitwa” i stawia się Ją za „wzór do naśladowania”.

Obradujące w tym czasie Sobory powszechne niezbyt wiele uwagi poświęcały Maryi z powodu sporów trynitarnych i chrystologicznych. Sobór

Por. A. Ziegenaus, Maria in der Heilsgeschichte. Mariologie, dz. cyt., s. 379.

2 Por. S. Praśkiewicz, Duchowość maryjna, Kraków 2008, s. 21-22 (Vita Consecrata, 29). 
Nicejski z 325 roku ani razu w swoich tekstach nie wymienił Jej imienia. Nie jest Ona nawet wspomniana w wyznaniu wiary ojców soborowych, kiedy jest mowa o zrodzeniu Jezusa Chrystusa ${ }^{3}$. Po raz pierwszy jest wymieniona dopiero w Wyznaniu wiary 150 ojców Soboru Konstantynopolitańskiego I z 381 roku, gdzie czytamy: „zstąpił z nieba i przyjął ciało za sprawą Ducha Świętego z Maryi Dziewicy" ". Przyczyną tych zmian nie była chęć pominięcia Maryi - dążono przede wszystkim do właściwego wyrażenia Bóstwa i ludzkiej natury Chrystusa.

Maryjna duchowość pierwszych wieków może być zdefiniowana jako duchowość naślad ow ania. Znaczącą rolę odgrywała wówczas wiara w dziewictwo Maryi, co umacniało decyzję o życiu w czystości. Ta motywacja jest wyraźnie czytelna w duchowości monastycznej. Maryja była widziana jako model dla konsekrowanych dziewic. Ten temat rozwijał św. Atanazy Wielki, określając Maryję jako wzór dla wszystkich chrześcijan5.

\subsubsection{Od soboru efeskiego do połowy średniowiecza (V-XI wiek)}

Istotą obrad Soboru w Efezie było określenie złożenia natury Boskiej i ludzkiej w jednej osobie Chrystusa. Ojcowie wyrazili to w następujących słowach:

Pragniemy wyłożyć w skrócie, jak myślimy i jak nauczamy o Bogarodzicy Dziewicy i o sposobie, w jaki Jednorodzony Syn Boży stał się człowiekiem. [...] Wierzymy więc, że Pan nasz Jezus Chrystus, Jednorodzony Syn Boży, jest doskonałym Bogiem i doskonałym człowiekiem, złożonym z rozumnej duszy oraz ciała, zrodzony z Ojca przed wiekami według Bóstwa, a „w ostatnich czasach" dla nas i dla naszego zbawienia z Maryi Dziewicy co do człowieczeństwa, współistotny Ojcu co do Bóstwa i współistotny nam co do człowieczeństwa. Nastąpiło bowiem zjednoczenie dwóch natur. Dlatego wyznajemy jednego Chrystusa, jednego Syna, jednego Pana. Z racji tego zjednoczenia bez pomieszania wierzymy, że święta Dziewica jest Bogarodzicą, ponieważ Słowo Boże się wcieliło, stało się człowiekiem, i że od chwili swego poczęcia zjednoczyło się ze świątynią, którą z Niej wzięło ${ }^{6}$.

\footnotetext{
3 Por. Sobór Nicejski I, Wyznanie wiary 318 ojców, [w:] Dokumenty Soborów Powszechnych, tekst grecki, łaciński, polski, t. I, 325-787 [dalej: DSP I], oprac. A. Baron, H. Pietras, Kraków 2001, s. 25.

4 Por. Sobór Konstantynopolitański I, Wyznanie wiary 150 ojców, [w:] DSP I, s. 69.

5 Por. S. C. Napiórkowski, Maryja w duchowości, [w:] EK, t. 12, Lublin 2008, k. 28.

6 Por. Sobór Efeski, Formuła zjednoczenia, [w:] DSP I, s. 177-178.
} 
Pewność i rozmach kultu maryjnego zapewnił Sobór Efeski, który ogłosił dogmat o Bożym macierzyństwie. Okres posoborowy należy widzieć jako czas szczególnego kultu i refleksji nad treścią prawdy dogmatycznej Theotokos. Tacy ojcowie Kościoła, jak Hezychiusz z Jerozolimy (zm. po 451), Bazyli z Seleucji (zm. 458), Modest z Jerozolimy (ok. 537-634), German z Konstantynopola, Andrzej z Krety, Jan Damasceński, w swoich homiliach tłumaczą teologiczne treści wynikające $\mathrm{z}$ kontemplacji tajemnicy Bożego rodzicielstwa.

Doktrynalne orzeczenia inicjują liturgię i dają jej prawomocność, dlatego zaczyna się obchodzić pierwsze święta maryjne: Ofiarowanie w Świątyni (Hypapante), Zaśnięcie (Dormitio), Zwiastowanie i Narodzenie. Rozwijają się nabożeństwa maryjne, jak np. miesiąc Maryi w Egipcie czy Akathistos. W początkach viıI wieku pojawia się przejście od uwielbienia Maryi do postawy służby wobec Niej.

Maryjną duchowość tego okresu określa się jako „duchowość zachwytu i wychwalania”. W homiliach coraz częściej sławi się wówczas Maryję jako Matkę Boga i Matkę Dziewicę, wyniesioną ponad całe stworzenie. Dobrym przykładem jest tu wspomniany już Akathistos, który około 800 roku zostaje przetłumaczony na język łaciński. W vi wieku te formy duchowości rozszerzyły się o duchowość oddania. W tym czasie pojawiła się bowiem w Kościele idea służebnego oddania się Maryi. Propagatorem tej duchowości był Ildefons z Toledo, zachęcający do niej następującymi słowami: „Domina mea, dominatrix mea, dominans mihi”"

\subsubsection{Między XI a XVI wiekiem}

O ile pierwsze wieki pobożności maryjnej zostały zdefiniowane przede wszystkim przez mentalność Wschodu, o tyle od xI wieku zaczyna dominować Zachód. Wiąże się to $\mathrm{z}$ jednej strony $\mathrm{z}$ upadkiem Konstantynopola (w 1453 roku), a z drugiej z rozwojem uniwersytetów, literatury, sztuki i kultury na zachodnim obszarze chrześcijaństwa.

W średniowieczu rozwijają się formy czci Maryi wynikające z postępującej klerykalizacji liturgii. Potwierdzeniem tego są np. Małe Oficjum, Różaniec, Litania Loretańska czy Anioł Pański. Tworzone są liczne utwory wysławiające Maryję, zawierające takie aklamacje jak: Ave, Gaude, Salve, Vale, O quam. Powstaje Psatterz Maryjny, zawierający 150 strof zaczynających się od słowa Ave, podzielony na trzy części, co da początek różańcowi,

7 Por. S. C. Napiórkowski, Maryja w duchowości, dz. cyt., k. 28-29. 
do którego Dominik z Prus (ok. 1384-146o) dołączy krótkie rozważania nad tajemnicami życia Maryi i Jezusa.

Potężny wkład w rozwój maryjnej czci wnoszą nade wszystko zakony. Trzeba tu przywołać dorobek zakonów serwitów, karmelitów, franciszkanów, dominikanów. Poszczególne ośrodki prześcigają się w nowych formach pobożności wobec Maryi. Dorobek klasztorów monastycznych naznaczają także fenomeny lokalnej kultury. W średniowieczu w wysławianiu Maryi akcentowano Jej postawę radości przy żłóbku oraz współcierpienie z ukrzyżowanym Jezusem (Pietà). W pobożności maryjnej pojawiają się liczne elementy kontemplacji i współczucia, ukazujące zaangażowanie Maryi w pasyjne misterium odkupienia ${ }^{8}$.

Warto także wspomnieć bogatą refleksję teologiczną, jaka wyszła spod pióra Jana Dunsa Szkota, Tomasza z Akwinu w jego Sumie teologicznej, Anzelma z Canterbury czy Bernarda z Clairvaux9.

Można odnotować również święta maryjne związane z osobą Matki Jezusa lub wyrażające określone aspekty pobożności maryjnej: Nawiedzenia NMP, Poczęcia Maryi, Matki Bożej Śnieżnej, Imienia Maryi, Matki Bożej od Wykupu Niewolników, Najświętszej Maryi Panny Zwycięskiej, Matki Bożej Szkaplerznej, Siedmiu Boleści Maryi, Objawienia Niepokalanej, Macierzyństwa NMP, Niepokalanego Serca NMP czy też Niepokalanego Poczęcia.

Mimo tych znaczących osiągnięć w ukazywaniu znaczenia Maryi jako Matki Zbawiciela w średniowieczu ujawniają się także błędne formy Jej czci. Często popada się w przesadę, nadmierną emocjonalność, nasila się pogoń za relikwiami, mnożą się objawienia bynajmniej nie autentyczne. Są podstawy, aby mówić o wręcz zabobonnych praktykach. Nasilająca się pobożność maryjna charakteryzuje się powierzchownością i spłyceniem, jest bardziej wpisana w lokalną tradycję i folklor niż w treści biblijnego przekazu czy kościelnego nauczania.

\subsubsection{Ruchy reformacyjne i Sobór Trydencki (1545-1563)}

Czas wyznaczony z jednej strony przez liczne ruchy reformacyjne, których początek należy zauważyć już w pierwszej połowie xv wieku, a z drugiej przez osiemnastoletnie (licząc przerwy) obrady Soboru Trydenckiego, jest na pewno znaczący w historii rozwoju maryjnej pobożności. Jest to z pewnością czas przejaskrawień i nieporozumień w obszarze kultu maryjnego,

Por. tamże.

9 Por. S. Praśkiewicz, Duchowość maryjna, dz. cyt., s. 24-25. 
kiedy często dochodziła do głosu jedynie chęć nadmiernego krytykowania lub też eksponowania tych elementów maryjności, które strona przeciwna zakwestionowała. Protestanci niejednokrotnie ganili i ośmieszali w maryjnej pobożności to, co niekiedy wcale nie występowało u katolików związanych z papiestwem. Z kolei rzymscy katolicy popadali w przesadę, rozwijając te elementy nabożeństwa, które - jak się im wydawało - odrzucali reformatorzy. Brak informacji, uprzedzenia, oszczerstwa i złe emocje tego okresu raczej wypaczyły kult dla Matki Jezusa niż przysporzyły Jej właściwej chwały. Mariologia oderwana od eklezjologii i chrystologii nie dawała poprawnych doktrynalnie podstaw do właściwego rozwoju maryjności. W świetle dzisiejszych osiągnięć dialogu ekumenicznego okazało się, że możliwy jest tzw. „zróżnicowany konsensus” - ponieważ większość zarzutów kierowanych przez teologię rzymską wobec reformatorów nie znajduje swojego rzeczywistego potwierdzenia. Podobnie i posądzenia reformatorów co do doktryny katolickiej są bezpodstawne. Obie strony wyznawały co innego, niż przypisywało się im w sporach szesnastowiecznych. A zatem zarówno ówczesne potępienia doktrynalne Soboru Trydenckiego nie dotyczyły ówczesnej nauki Kościołów luterańskich (Księgi Wyznaniowe), jak i odrzucanie katolickiej doktryny przez reformatorów nie powinno mieć miejsca ${ }^{10}$.

Należy także zaznaczyć i to, że Sobór Trydencki nie podjął tematyki maryjnej. Pewne aspekty mariologii pojawiły się jedynie w kontekście uchwał o grzechu pierworodnym czy o kulcie świętych. Propagowana pobożność maryjna miała często charakter apologetyczny.

Niemniej warto zauważyć powstanie Sodalicji Mariańskiej, zainicjowanej przez o. Jeana Leunisa w 1563 roku wśród studentów jezuickiego Kolegium Rzymskiego. Sodalicja dość szybko rozpowszechniła się we włoskojęzycznych księstwach. Równie sprawnie została przeniesiona poza ich granice dotarła także do Polski. Istotą Sodalicji było poświęcenie się Maryi, którą obierano sobie za patronkę, Wspomożycielkę i Obrończynię.

\subsubsection{Maryjne szkoły duchowości w XVII i XVIII wieku}

Brak doktrynalnych wskazań Tridentinum odnośnie do kształtu tak mariologii, jak i maryjności wyzwolił bogatą refleksję teologiczną o różnej

${ }^{10}$ Por. A. A. Napiórkowski, Bogactwo łaski a nędza grzesznika. Zróżnicowany konsensus teologii katolickiej i luterańskiej o usprawiedliwianiu, Kraków 2011, s. 15-20, 362-398. 
kwalifikacji teologicznej oraz liczne formy czci Maryi, niekiedy o dość wątpliwej wartości i zgodności z chrześcijańskim objawieniem.

Godne odnotowania jest powstanie dwóch pierwszych traktatów o Najświętszej Maryi Pannie. Pierwszą rozprawę o Maryi, zatytułowaną De Deipara et Christo ut eius Filio, napisał Franciszek Suárez, a następną, Summa sacrae mariologiae, Placido Nigido.

W tym okresie powstają także liczne sanktuaria maryjne ${ }^{11}$, co wiązało się z koronacją figur Matki Bożej i obrazów oraz obieraniem Jej przez poszczególne nacje i narody za swoją szczególną patronkę i królową. Francja została Jej poświęcona w 1638 roku, Portugalia w 1646 roku, Austria w 1647 roku, Polska w 1656 roku.

Specyfiką tego okresu jest wykształcenie się form duchowości maryjnej, które odchodzą od sporadycznego jedynie odwoływania się do Matki Jezusa, a zachęcają wiernych do przeżywania chrześcijaństwa w szkole Maryi. Powstają zatem szkoły maryjnej duchowości. Wymownym potwierdzeniem tego jest tzw. święte niewolnictwo wobec Matki Bożej czy życie na wzór Maryi i dla Maryi szkoły karmelitańskiej. Idea niewolnictwa jako praktyka całkowitego oddania się Maryi rozwinęła się w całej pełni w XVII wieku i przyjęła nazwę „doskonałego nabożeństwa”. Postawę całkowitego oddania się na rzecz i własność Maryi, zawierzenie się Jej, realizowali we Francji zwłaszcza kard. Pierre de Bérulle i św. Ludwik Maria Grignion de Montfort. Ten francuski kapłan uważany jest za pioniera pobożności maryjnej, której wyrazem jest jego najbardziej znane dzieło pt. Traktat o prawdziwym nabożeństwie do Najświętszej Maryi Panny, w którym rozwinął on koncepcję niewolnictwa duchowego jako dobrowolnego i ufnego poddania Maryi. Grignion de Montfort pisze tam między innymi:

Prawdziwe nabożeństwo do Najświętszej Maryi Panny jest święte, to znaczy prowadzi duszę do unikania grzechu i do naśladowania cnót Najświętszej Maryi Panny, zwłaszcza Jej głębokiej pokory, żywej wiary, ślepego posłuszeństwa, nieustającej modlitwy, wszechstronnego umartwienia, Boskiej czystości, Jej głębokiego miłosierdzia, Jej heroicznej cierpliwości, Jej anielskiej słodyczy i iście Boskiej mądrości. Oto dziesięć głównych cnót Najświętszej Maryi Panny.

${ }^{11}$ Zob. W. Gumppenberg, Atlas Marianus, sive De imaginibus Deiparae per orbem Christianum miraculosis, Ingolstadt 1657 . Bawarski jezuita opisuje w swoim atlasie 1200 miejsc pielgrzymkowych (zwłaszcza w Niemczech, Tyrolu i Szwajcarii), gdzie czczona jest Maryja. 
Z kolei święte niewolnictwo wobec Matki Bożej będzie w Hiszpanii rozpowszechniane przez św. Szymona de Rojasa (1552-1624) oraz przez augustianina Bartłomieja de los Rios y Alarcon (1580-1652), a w Polsce przez Franciszka Stanisława Fenickiego i Kacpra Drużbickiego. Mariańska szkoła duchowości wiele zawdzięcza św. Stanisławowi Papczyńskiemu (1631-1701), który propagował kierunek życia duchowego skoncentrowany na osobistym związku i przyjaźni z Bogiem, wszczepieniu w Jezusa Chrystusa, kult Niepokalanie Poczętej i Jej naśladowanie. Kierunek ten, pogłębiony przez Kazimierza Wyszyńskiego (1700-1755) i odnowiony przez bł. Jerzego Matulewicza (1871-1927), propagują obecnie księża marianie ${ }^{12}$.

W omawianym przez nas okresie ukształtowały się dwa nurty maryjnej pobożności, akcentujące wielkość Maryi jako Matki Bożej i Matki Miłosierdzia. Pierwszy z nich eksponował tradycyjne tytuły i zalecał praktyki pobożne. $Z$ kolei drugi podkreślał bezpośredni dostęp wiernych do Boga, niewymagający pośrednictwa Maryi. Ten pierwszy nurt utożsamiano z religijnością ludową, kwalifikowaną jako niższa, bardziej emocjonalna. Natomiast drugi oceniano jako bardziej poprawny teologicznie i praktykowany przez elity ${ }^{13}$.

W xx wieku duchowość maryjna jako święte niewolnictwo wobec Matki Bożej zostanie na nowo podjęta przez bł. Honorata Koźmińskiego (18291916), św. Maksymiliana Marię Kolbego czy sługę Bożego Stefana Wyszyńskiego (1901-1981). Do tej formy duchowości w ujęciu Grignion de Montforta nawiąże również Karol Wojtyła (1920-2005), który zaczerpnie z jego dzieła zwrot „Totus Tuus”, obierając go za swoją dewizę biskupią, a później także papieską.

\subsubsection{Apogeum kultu (1854-1950)}

Przewartościowania i nadmierne eksponowanie niektórych cech Maryi wywołały krytykę. Szczególnie naiwna pobożność, legendarne podania i przekazy poddano racjonalnej ocenie. Przykładem tego są pozycje Ludwika Antoniego Muratoriego, który w swoich dziełach (De ingeniorum moderatione in religionis negotio oraz Della regolata devozione dei cristiani) napiętnował niektóre aspekty ludowej religijności. Bardziej zrównoważone i teologicznie poprawniejsze ujęcie przedłożył św. Alfons Maria de Liguori,

12 Por. S. Praśkiewicz, Duchowość maryjna, dz. cyt., s. 28-29; por. J. Pach, Duchowe macierzyństwo Maryi w kerygmie Stefana Kardynała Wyszyńskiego, sm 13 (2011) nr 3-4, s. 186-219.

13 Por. S. C. Napiórkowski, Maryja w duchowości, dz. cyt., k. 30. 
który w swoim dziele Uwielbienia Maryi (Glorie di Maria) przedstawia Ją jako opatrznościową Matkę dla chrześcijan na całe życie. Prawdziwego pogłębienia duchowości maryjnej dokonał jednak M. J. Scheeben, integrując mariologię z teologią dogmatyczną i rozwijając ideę macierzyństwa oblubieńczego. Powiązał on Maryję z Chrystusem, przez co stała się ideałem dla Kościoła i duchową Matką wszystkich ludzi. Warto też zauważyć wkład bł. J. H. Newmana, który podkreślał rozróżnienie na wiarę i rodzaje oraz formy pobożności, zależne m.in. od kontekstu kulturowego, epoki czy kraju. Zdaniem Newmana prawdziwa pobożność katolicka, eksponując Maryję jako służebnicę swojego Syna, a nie rywalkę, nigdy nie usuwa w cień Chrystusa. Ponadto kraje, które odeszły od czci Maryi, utraciły też wiele $\mathrm{z}$ wiary w Chrystusa - konkluduje angielski kardyna $1^{14}$.

Bez wątpienia te teologiczne rozważania wniosły swój interesujący i wartościowy wkład w odrodzenie kultu maryjnego, który od drugiej połowy XIX wieku aż po lata pięćdziesiąte Xx wieku nazywany jest niekiedy „erą Maryi”. Ponadto duchowość maryjna w omawianym okresie wzbogaciła się o trzy nowe, żywotne do dzisiaj formy: przymierze z Maryją, życie życiem Maryi oraz zdobycie całego świata dla Chrystusa przez Niepokalaną. Najczęściej te formy czci wobec Matki Jezusa łączone są - zresztą słusznie - z osobą św. Maksymiliana M. Kolbego oraz ze zgromadzeniami zakonnymi marianistów i marystów ${ }^{15}$.

Ten stuletni okres wypełniają liczne objawienia. Z tych objawień prywatnych oficjalnie zostały uznane przez Kościół następujące: Katarzynie Labouré (1830, cudowny medalik), pasterzom w La Salette (1846), Bernadecie Soubirous (Lourdes 1858), dwóm dziewczynkom w Gietrzwałdzie na Warmii (1877), w irlandzkim Knock (1879), dzieciom w portugalskiej Fatimie (1917), w belgijskich wioskach Beauraing (1933) i Banneux (1933), na Sycylii w Syrakuzach (1953). Można dodać, że zainteresowanie objawieniami maryjnymi w ostatnich latach znacznie się nasiliło. Ta nadmierna tendencja do koncentrowania się na tym, co fragmentaryczne i drugorzędne w sprawach chrześcijańskiej wiary, jest mocnym sygnałem dla całego Kościoła i duszpasterstwa maryjnego. W pobożności ludowej dochodzi

${ }^{14}$ Por. S. C. Napiórkowski, Maryja $w$ duchowości, dz. cyt., k. 30; zob. A. A. Napiórkowski, Schrift, Tradition, Kirche. Glaubensquelle in Matthias Joseph Scheebens theologischer Erkenntnislehre, Frankfurt am Main 1996, s. 295.

${ }^{15}$ Por. S. Praśkiewicz, Duchowość maryjna, dz. cyt., s. 29. 
do zagubienia hierarchii prawd i całej treści objawienia judeochrześcijańskiego $^{16}$.

\subsubsection{Sobór Watykański iI: reforma kultu maryjnego}

$\mathrm{W}$ teologii xIx i do połowy xx stulecia dość wszechwładnie królowały zasady de Maria numquam satis, numquam nimis („o Maryi nigdy dość, nigdy za dużo”) oraz ad Iesum per Mariam („do Jezusa przez Maryję”), które stały się przyczyną powstania swoistego nurtu maksymalizmu w maryjnej pobożności. Wyraził się on wielkim rozwojem kultu maryjnego, co ujawniło się w różnorakich formach nabożeństw (różaniec, szkaplerz, miesiące maryjne ${ }^{17}$, nawiedzenia obrazów Matki Bożej, nasilenie ruchu pielgrzymkowego do sanktuariów maryjnych). Zaczęły jednakże z czasem pojawiać się głosy ostrzegawcze czy nawet krytyczne.

Interesującą książką, która pojawiła się tuż na początku Soboru Watykańskiego II, była praca francuskiego mariologa René Laurentina La question mariale, wydana w 1963 roku, w której pisał on:

Pojawiło się od kilku lat w Kościele wielkie napięcie pomiędzy pobożnością chrystocentryczną i pobożnością mariocentryczną; innymi słowy, pomiędzy pobożnością całkowicie skierowaną na Maryję lub zupełnie odcinającą się od Niej. Stało się to wskutek przekształcenia pobożności maryjnej w religię maryjną. Przykrą tego konsekwencją może się stać, niejako na przekór, powstanie religii chrześcijańskiej bez Maryi ${ }^{18}$.

Potwierdzając stanowisko R. Lauretina, wielu teologów zauważyło, że w niektórych środowiskach katolickich kult maryjny odszedł od apostolskiej tradycji pierwszych wieków, w którym centrum kerygmatu stanowiło przepowiadanie zmartwychwstałego Pana. Kultowi maryjnemu postawiono zarzut przesadnego marianizmu, ukrytego monofizytyzmu i niezdrowego sentymentalizmu oraz przeceniania znaczenia prywatnych objawień maryjnych ${ }^{19}$. W takiej sytuacji zbawienne okazały się obrady Soboru Watykań-

${ }^{16}$ W ostatnich latach doszły nowe maryjne objawienia zatwierdzone przez Kościół: w Akita (Japonia) w 1973 i w Kibeho (Rwanda) w latach 1981-1983; zob. J. Kumala, Fenomen zjawień maryjnych w przestrzeni pobożności ludowej, sm 11 (2009) nr 1, s. 59-74.

${ }^{17}$ Dlaczego nie ma - można zapytać - w Kościele powszechnym miesiąca Ducha Świętego?

${ }^{18}$ Cytuję za: S. Praśkiewicz, Duchowość maryjna, dz. cyt., s. 33. Z tekstów R. Laurentina w języku polskim warto się zapoznać z książką Matka Pana. Traktat teologiczny, dz. cyt.

${ }_{19}$ S. Praśkiewicz, Duchowość maryjna, dz. cyt., s. 33. 
skiego II i jego doktrynalne rozstrzygnięcia. Dobrze się stało, że Sobór nie przedłożył osobnego dokumentu o Matce Jezusa, lecz nauczanie o Niej wyraził w viII rozdziale Konstytucji dogmatycznej o Kościele Lumen gentium. Wpisując mariologię i maryjność w eklezjologię i chrystologię, ojcowie soborowi wskazali dalszy kierunek właściwego rozwoju kultu maryjnego:

Sobór święty, wykładając naukę o Kościele, w którym Boski Odkupiciel dokonuje zbawienia, pragnie starannie wyjaśnić zarówno rolę Błogosławionej Dziewicy w misterium Słowa Wcielonego i Ciała Mistycznego, jak i obowiązki odkupionych ludzi względem Bogarodzicy, Matki Chrystusa i Matki ludzi, zwłaszcza wierzących w Chrystusa; nie zamierza jednak przedstawiać pełnej nauki o Maryi ani rozstrzygać kwestii jeszcze nie wyjaśnionych jeszcze przez teologów. Zachowują więc nadal swoje prawo poglądy, jakie w szkołach katolickich swobodnie podaje się o Tej, która w Kościele świętym zajmuje miejsce najwyższe po Chrystusie i nam najbliższe $e^{20}$.

Tenże rozdział - zatytułowany Błogosławiona Maryja Dziewica Boża Rodzicielka w tajemnicy Chrystusa i Kościoła - nie wytycza wyłącznie dalszego kierunku dla mariologii, lecz podaje ważne treści na temat Maryi i form pobożności do Niej ${ }^{21}$. Z jednej strony Sobór zachęca do maryjnej pobożności, a z drugiej przestrzega przed ciasnotą myślenia, sentymentalizmem i łatwowiernością.

Sobór [...] napominając wszystkich synów Kościoła, aby szczerze popierali kult Błogosławionej Dziewicy, szczególnie liturgiczny, a praktyki i zbożne ćwiczenia ku Jej czci zalecane w ciągu wieków przez Urząd Nauczycielski cenili wysoko i to, co postanowione było w minionych czasach o kulcie obrazów Chrystusa, Błogosławionej Dziewicy i Świętych, pobożnie zachowywali. Teologów zaś i głosicieli słowa Bożego gorąco zachęca, w rozważaniu szczególnej godności Bogarodzicielki wystrzegali się pilnie zarówno wszelkiej fałszywej przesady, jak i zbytniej ciasnoty umysłu. Studiując pilnie pod przewodem Urzędu Nauczycielskiego Pismo Święte, Ojców i doktorów oraz liturgie Kościoła, niechaj we właściwy sposób wyjaśniają dary i przywileje Błogosławionej Dziewicy, które zawsze odnoszą się do Chrystusa, źródła wszelkiej prawdy, świętości i pobożności. Niech się pilnie wystrzegają wszystkiego, cokolwiek

\footnotetext{
${ }^{20} \mathrm{KK} 54$.

${ }^{21}$ Zob. KK 52-69.
} 
w słowach lub czynach mogłoby braci odłączonych lub jakichkolwiek innych ludzi wprowadzić w błąd co do prawdziwej nauki Kościoła. Niechaj następnie wierni pamiętają o tym, że prawdziwa pobożność nie polega ani na czczym i przemijającym uczuciu, ani na jakiejś próżnej łatwowierności, lecz pochodzi z wiary prawdziwej, która prowadzi nas do uznawania przodującego stanowiska Bogarodzicielki i pobudza do synowskiej miłości ku Matce naszej oraz do naśladowania Jej cnót ${ }^{22}$.

W dziejach polskiej recepcji wskazań Vaticanum II odnośnie do reform kultu maryjnego nie brak osiągnięć. Dostrzec można znaczne ubogacenie wcześniejszego modelu modlitwy „do Maryi” przez modele Jej naśladowania, życia jak Ona. Zawdzięczamy to postępującemu ubiblijnieniu kultu maryjnego, lepszym materiałom homiletycznym, wyższemu poziomowi kaznodziejstwa, katolickim rozgłośniom radiowym o zasięgu diecezjalnym i krajowym, odnowie liturgii ${ }^{23}$.

\subsection{Dlaczego należy czcić Maryję?}

Studiując nauczanie Magisterium Kościoła ostatniego czasu, a zwłaszcza rozdział viII wspomnianej Konstytucji dogmatycznej Lumen gentium oraz dwie adhortacje Pawła vi Marialis cultus i Signum magnum, a także encyklikę św. Jana Pawła II Redemptoris Mater i jego list apostolski Rosarium Virginis Mariae, można odwołać się do czterech głównych podstaw czci Maryi z Nazaretu. Są to: 1. Boże macierzyństwo, 2. współdziałanie w dziele zbawienia, 3. duchowe macierzyństwo, 4. świętośćc ${ }^{24}$.

Maryję czcimy przede wszystkim dlatego, że jest Theotokos, czyli Matką Jezusa Chrystusa jako prawdziwego Boga i prawdziwego człowieka. Vaticanum II naucza: „Maryja Dziewica [...] jest uznawana i czczona jako prawdziwa Matka Boga i Odkupiciela"25. Z tajemnicy Jej Bożego rodzicielstwa wypływa cześć i wdzięczność dla Niej. Rodzicielstwo Maryi ma przy

\footnotetext{
${ }^{22}$ KK 67.

${ }^{23}$ Por. T. Siudy, Recepcja myśli soborowej $w$ kulcie maryjnym w Polsce, sM 16 (2014) nr 1-4, S. $171-187$.

24 Por. KK 66.

25 KK 53.
} 
tym charakter wybitnie mesjański - przez Nią przyszedł na świat Chrystus, w którym doszło do pojednania człowieka z Bogiem.

Drugą podstawą kultu maryjnego jest współdziałanie Maryi w dziele zbawczym. Będąc Matką Zbawiciela, Maryja okazała się także „Towarzyszką Odkupiciela” (Socia Redemptoris), „Służebnicą Pańską”, „Nową Ewą”. Ojciec Święty Paweł vi zauważa, iż wieloraka więź Maryi ze zbawczym dziełem Chrystusa odzwierciedla się w różnych świętach maryjnych w ciągu całego roku liturgicznego.

Kolejne uzasadnienie podstaw kultu maryjnego można odnaleźć w Jej duchowym macierzyństwie. Uczestnictwo Maryi w ziemskich wydarzeniach zbawczych Mesjasza ma swoją naturalną ciągłość w Jej chwalebnym życiu. Po swoim wniebowzięciu Maryja kontynuuje i rozwija Jezusowy testament spod krzyża, aby stać się Matką - poprzez osobę Jana Ewangelisty - dla wszystkich wierzących w Chrystusa. Po macierzyńsku wstawia się nieustannie za nami z rzeczywistości niebiańskiej. Takie stanowisko uzasadnia tekst soborowej konstytucji, w której występują znamienne cztery tytuły Maryi: „Orędowniczki”, „Wspomożycielki”, „Pomocnicy” i „Pośredniczki”". Przekonanie o duchowym macierzyństwie Maryi potwierdził również Paweł vi w adhortacji Signum magnum. Czytamy:

Od tej chwili, gdy uczestniczyła w odkupieńczej dla nas ofierze Syna, i to w sposób tak bliski, iż zasłużyła być przez Niego ogłoszona Matką nie tylko jednego ucznia Jana, ale również (niech wolno będzie to stwierdzić) rodzaju ludzkiego, którego On był jakby przedstawicielem - Maryja obecnie w dalszym ciągu pełni z nieba obowiązek macierzyński, przyczyniając się do rodzenia i pomnażania życia Bożego w poszczególnych duszach ludzi odkupionych. Jest to ogromnie pocieszająca prawda, która $\mathrm{z}$ wolnej woli najmędrszego Boga jest częścią

${ }^{26}$ KK 62: „To macierzyństwo Maryi w ekonomii łaski trwa nieustannie - poczynając od aktu zgody, którą z wiarą wyraziła przy zwiastowaniu i którą zachowała bez wahania pod krzyżem aż do wiekuistego dopełnienia się zbawienia wszystkich wybranych. Wzięta do nieba, nie zaprzestała pełnić tej zbawczej roli, lecz poprzez swoje wielorakie wstawiennictwo ustawicznie wyjednuje nam dary wiecznego zbawienia. Dzięki macierzyńskiej miłości opiekuje się braćmi swego Syna, pielgrzymującymi jeszcze i narażonymi na niebezpieczeństwa i trudy, dopóki nie zostaną doprowadzeni do szczęśliwej ojczyzny. Dlatego do Błogosławionej Dziewicy stosuje się w Kościele w wezwaniach tytuły: Orędowniczki, Wspomożycielki, Pomocnicy, Pośredniczki. Rozumie się je jednak w taki sposób, że nie ujmują ani nie przydają one niczego godności i skuteczności działania Chrystusa, jedynego Pośrednika”. 
dopełniającą tajemnicy ludzkiego zbawienia, dlatego wszyscy chrześcijanie mają obowiązek w nią wierzyćc ch $^{2}$.

Czwarta podstawa kultu maryjnego wypływa ze świętości Maryi. Już od pierwszych wieków Kościół był przekonany, że Maryję należy czcić z powodu Jej niezwykłej świętości. Teksty liturgiczne od początku określały Ją jako „Matkę Najświętszą”. Ostatni Sobór potwierdza to przekonanie, nauczając, że Bogarodzica jest cała święta i wolna od wszelkiej zmazy grzechowej, czyli jest nowym stworzeniem ${ }^{28}$.

W tych czterech wymienionych powyżej podstawach kościelne Magisterium upatruje uzasadnienia kultu maryjnego. Maryja jest darem Trójjedynego Boga. Kto zaś przyjmuje tę świętą Matkę, będącą Matką Mesjasza i Matką wszystkich wiernych, wkracza w przestrzeń Kościoła, gdzie w sposób pewny udzielane są dary zbawcze ${ }^{29}$.

Oprócz uzasadnienia kultu maryjnego Vaticanum II wylicza ponadto cztery elementy, które opisują naturę kultu Najświętszej Maryi Panny: 1. c ze ść ponieważ jest Ona Matką Bożą; 2. miło ść - bo jest także naszą Matką; 3. przyzywanie i prośba - ponieważ Jej wstawiennictwo jest skuteczne; 4 . na śla d ow a n i e - gdyż jako święta jest Ona wzorem Kościoła ${ }^{30}$.

\subsection{Teologia kultu Maryi}

Niezwykłe miejsce Maryi w kulcie chrześcijańskim wyraża się w licznych świętach maryjnych roku liturgicznego, które ukazują całą głębię czci, jaką Kościół oddaje Matce Chrystusa. O kulcie maryjnym świadczą rozsiane po całym świecie kościoły pod wezwaniem Najświętszej Maryi Panny zbudowane przed wiekami i wciąż wznoszone ku Jej czci. Liczne dziedziny sztuki są wymownym świadectwem roli, jaką Jej osoba odgrywała i ciągle odgrywa w kulcie o inspiracji chrześcijańskiej. Zmysł wiary Ludu Bożego kieruje od wieków uwagę i uczucia wiernych ku licznym sanktuariom

${ }^{27}$ Paweł vi, Adhortacja Signum magnum do Biskupów, kapłanów i wiernych całego Katolickiego świata o radości chrześcijańskiej, 1.

${ }^{28}$ Por. KK 56.

${ }^{29}$ Por. T. Siudy, Źródła i podstawy kultu maryjnego, [w:] Kościół czci Matkę swego Pana. Sympozjum mariologiczne zorganizowane przez Wyższe Seminarium Duchowne w Przemyślu $w$ dniu 23 października 2002 r. Materiały, red. W. Siwak, Przemyśl 2003, s. 18-25.

${ }^{30}$ Por. KK 66. 
maryjnym, będącym świadectwem i szkołą życia chrześcijańskiego (Lourdes, Fatima, La Salette, Einsiedeln, Altötting, Guadalupe, Gietrzwałd, Jasna Góra). Dla wielu rodzin zakonnych, żeńskich i męskich, stała się Maryja wzorem bycia poświęconego Bogu. Wgląd w pobożność maryjną Kościoła katolickiego umożliwiają liczne modlitwy tak liturgiczne, jak i pozaliturgiczne, kierowane do Maryi i wraz z Maryją do Trójjedynego Boga.

Symbol wiary Quicumque, zwany atanazjańskim, mówi, że wiara katolicka polega na tym, „abyśmy czcili jednego Boga w Trójcy, a Trójcę w jedności”. Kult chrześcijański polega zatem na oddawaniu czci Ojcu Niebieskiemu przez Syna w Duchu Świętym. Kult ten, jak podkreśla papież Paweł vI, bierze od Chrystusa początek i skuteczność, „w Chrystusie znajduje pełny wyraz oraz przez Chrystusa w Duchu Świętym prowadzi do Ojca”.

Kult chrześcijański ma charakter responsoryjny, to znaczy jest odpowiedzią człowieka na odkupieńcze działanie Boga, na uprzedzający dar, którego Ojciec udzielił przez Chrystusa w Duchu Świętym. W tej zstępującej linii miłosiernego działania Trójcy Świętej uczestniczy Maryja, w sposób szczególny złączona ze wszystkimi Boskimi Osobami. Odpowiedź na zbawcze działanie Boga, czyli kult chrześcijański, musi uwzględnić Maryję w modlitwie Kościoła wznoszącej się ku Ojcu przez Chrystusa w Duchu Świętym. Tak więc cześć oddawana Maryi nie sprzeciwia się fundamentalnemu ukierunkowaniu chrześcijańskiego kultu na Trójcę Przenajświętszą. Kto z miłością oddaje cześć Bogu przez Chrystusa w Duchu Świętym, ten równocześnie okazuje cześć i miłość ludziom należącym do Niego w sposób szczególny. I odwrotnie: oddając z miłością cześć ludziom, w których w sposób wyjątkowy objawiły się dzieła Boże, oddajemy cześć Trójjedynemu Bogu. Właściwie rozumiany kult świętych jest więc chwałą trynitarnego Boga.

Kult maryjny jest szczególnym przypadkiem czci oddawanej w Kościele. Ostatni Sobór przypomniał w zdecydowany sposób prawdę o powszechnym powołaniu do świętości, która nie jest zadaniem tylko nielicznych i wybranych, ale zwyczajnym kresem dążeń chrześcijanina. Nie bez powodu Paweł Apostoł w wielu miejscach nazywa chrześcijan po prostu świętymi. Ci, którzy osiągnęli już cel, do którego dąży wspólnota chrześcijan, winni stać się więc przedmiotem szczególnej uwagi społeczności Kościoła.

Najświętsza Maryja Panna zajmuje wyjątkowe miejsce w szeregu świętych z racji swego szczególnego związku z Chrystusem i niezwykłej roli, jaką odgrywa w Bożym planie zbawienia. Pobożność maryjna stanowi - według papieża Pawła vi - wyborną cząstkę tego religijnego kultu, w którym głębia 
mądrości i szczyt religijności jakby zlewają się w jedno i który dlatego jest szczególnym zadaniem Ludu Bożego.

Cześć oddawana Maryi różni się istotnie od kultu uwielbienia, który przysługuje jedynie Bogu. Wcześniejsza teologia odróżniała cześć oddawaną Bogu (gr. latreia, łac. adoratio, stąd łaciński termin cultus latriae) od czci oddawanej osobom i rzeczom ze względu na Boga (gr. doulia, łac. veneratio, stąd termin cultus duliae) Kult maryjny nie jest więc celem samym w sobie, ale ma kierować człowieka ku chwale Boga w Trójcy Jedynego. Szczególne miejsce czci oddawanej Maryi w Kościele określa tradycyjna teologia terminem cultus hyperduliae - „kult wyższej pochwały”. Na temat kultu maryjnego wypowiedział się Sobór Watykański II. Konstytucja o Liturgii rozważa miejsce Maryi w kulcie Kościoła w kontekście obchodzonych w roku liturgicznym tajemnic Chrystusa:

Obchodząc ten roczny cykl misteriów Chrystusa, Kościół święty ze szczególną miłością oddaje cześć Najświętszej Matce Bożej, Maryi, która nierozerwalnym węzłem złączona jest ze zbawczym dziełem swojego Syna. W Niej Kościół podziwia i wysławia wspaniały owoc odkupienia i jakby w przeczystym obrazie $\mathrm{z}$ radością ogląda to, czym cały pragnie i spodziewa się byćs ${ }^{31}$.

Konstytucja Lumen gentium poświęca natomiast osobny fragment rozdziału viıI czci oddawanej Maryi. Sobór rozważa pokrótce naturę i podstawy teologiczne kultu maryjnego. Dzięki łasce Bożej Maryja jest wyniesiona "ponad wszystkich świętych i aniołów” 32 i doznaje w Kościele szczególnej czci (speciali cultu honoratur) ze względu na uczestnictwo w tajemnicach Jezusa Chrystusa. Dokument podkreśla, że kult maryjny trwa w Kościele od wieków, zwłaszcza zaś od czasów Soboru Efeskiego, który potwierdził tytuł Bożej Rodzicielki dla Maryi. Określając naturę kultu maryjnego, Sobór nie sięga już do tradycyjnego podziału na cultus latriae i cultus duliae. Mówi natomiast, że cześć oddawana Bożej Rodzicielce różni się w sposób istotny od kultu uwielbienia (cultus adorationis), który składany jest jedynie Bogu w Trójcy Świętej. Kult uwielbienia jest kultem absolutnie wyjątkowym i jedynym w swoim rodzaju.

${ }^{31}$ Sobór Watykański II, Konstytucja dogmatyczna o liturgii Sacrosanctum concilium [dalej: $\mathrm{KL}], 103$.

${ }^{32}$ KK 69. 
Podsumowując, należy stwierdzić, iż przedsoborowy podział kultu na latria (kult Boga), hyperdulia (Najświętszej Maryi Panny) oraz dulia (świętych i błogosławionych) został zniesiony. Obecnie obowiązuje podział dwustopniowy, na uwielbienie i cześć. Wyłącznie Trójjedynemu Bogu przysługuje uwielbienie (cultus adorationis), a do Najświętszej Maryi Panny, do świętych i błogosławionych odnosi się cześć (veneratio). Cześć względem Maryi nie stoi w sprzeczności z kultem oddawanym Bogu w Chrystusie. Oddając cześć Matce, poznaje się przecież, kocha i w sposób należyty wielbi się Jej Syna i zachowuje Jego przykazania. Kult Matki Chrystusa, taki jak zawsze istniał w Kościele - choć jest wyjątkowy, to jednak różni się w sposób istotny od kultu uwielbienia, który oddawany jest Słowu Wcielonemu na równi z Ojcem i Duchem Świętym. Poprawny kult ostatecznie jak najbardziej sprzyja kultowi uwielbienia Trójcy Świętej33.

Ojcowie Soboru podają też kilka praktycznych zaleceń dotyczących nauczania i kultu. Do wszystkich wierzących kierują zachętę, aby popierali uświęcone tradycją formy kultu maryjnego. Teologowie zaś i głosiciele słowa Bożego winni w rozwijaniu nauki o Matce Chrystusa unikać dwóch skrajności: z jednej strony strzec się „wszelkiej fałszywej przesady”, z drugiej zaś unikać „nadmiernej ciasnoty umysłu”. Prawdy maryjne ukazywane być powinny w ustawicznym odniesieniu do Chrystusa, „źródła wszelkiej prawdy, świętości i pobożności". Ważny jest również wzgląd ekumeniczny. Trzeba się wystrzegać wszystkiego, co „w słowach lub czynach mogłoby braci odłączonych albo jakichkolwiek innych ludzi wprowadzić w błąd co do prawdziwej nauki Kościoła”. Dokument przestrzega na koniec przed zbytnim akcentowaniem uczuciowości w rozwijaniu kultu maryjnego, zachęca natomiast do pogłębiania wiary, która prowadzi „do uznania wyjątkowego wyniesienia Bożej Rodzicielki i pobudza do dziecięcej miłości ku naszej Matce oraz do naśladowania Jej cnót”34.

\subsection{1. Źródła kultu maryjnego}

Refleksja teologiczna omawiająca kult Maryi w Kościele musi naturalnie odwoływać się do teologicznych źródeł i podstaw tego kultu. Tutaj bowiem znajduje się nie tylko uzasadnienie, lecz także właściwe ukierunkowanie czci dla Matki naszego Zbawiciela. Stąd biorą swój kształt i cechy charakterystyczne formy kultu maryjnego.

\footnotetext{
${ }^{33}$ Por. KK 66.

${ }^{34}$ кк 67. Por. S. Budzik, Maryja w tajemnicy Chrystusa i Kościoła, dz. cyt., s. 136-139.
} 


\subsubsection{MiEJSCA BIBLIJNE}

Obok Tradycji do podstawowych form, w jakich uzewnętrzniło się objawienie chrześcijańskie, należy Pismo Święte Starego i Nowego Testamentu. Jakkolwiek księgi Starego Testamentu wprost i bezpośrednio nie mówią o Maryi, to jednak znajdujemy na ich kartach wiele zapowiedzi i figur, które - w świetle Nowego Testamentu - wolno i należy odnieść do Maryi jako Matki Mesjasza.

Możemy wskazać kilka miejsc biblijnych, które stanowią rzetelne uwiarygodnienie i umocowanie maryjnej czci, więcej nawet: ta cześć do Najświętszej Maryi Panny jest w ich świetle biblijnym nakazem i obowiązkiem wierzących w Chrystusa. Te miejsca to: $Ł k ~ 1,28 ; 1,42 ; 1,48 ; 11,27$; Rz 1, 20. Poddajmy krótkiej analizie owe biblijne wersety.

1. Pozdrowienie anioła - Łk 1, 28. Słowa anioła: „Bądź pozdrowiona, pełna łaski, Pan z Tobą" oznaczają wezwanie Maryi, aby się radowała i weseliła. Hebrajskim ich odpowiednikiem jest „pokój z tobą”. Z Maryją wiąże się nowa radość. Dlaczego Maryja ma się cieszyć? Gdyż z Nią jest Pan. A zatem jest to radość idąca od Boga. Aby lepiej zrozumieć sens tego pozdrowienia, należy odwołać się do tekstów starotestamentalnych, tj. So 3 , 14-18a; Jl 2, 21; Za 9, 9; Lm 4, 21, ponieważ w każdym z nich jest mowa o mesjańskiej radości. Przypatrzmy się bliżej obietnicy kierowanej do Izraela przez Sofoniasza. Prorok głosi: „Wyśpiewuj, Córo Syjońska! Podnieś radosny okrzyk, Izraelu! Ciesz się i wesel z całego serca, Córo Jeruzalem! Oddalił Pan wyroki na ciebie, usunął twego nieprzyjaciela: król Izraela, Pan, jest pośród ciebie, nie będziesz już bała się złego. Owego dnia powiedzą Jerozolimie: Nie bój się, Syjonie! Niech nie słabną twe ręce! Pan, twój Bóg, jest pośród ciebie, Mocarz - On zbawi, uniesie się weselem nad tobą, odnowi swą miłość, wzniesie okrzyk radości (jak w dniu uroczystego święta)”. Maryja jest porównana do Córy Syjonu, a nawet można rzec więcej: jest w swej osobie Córą Syjonu, a Jezus, którego ma zrodzić, jest zrównany z Jahwe. Jak w łonie Izraela (Arce Przymierza) zamieszkuje Jahwe, tak w łonie Dziewicy z Nazaretu - która stanie się nową Arką Przymierza - zamieszka Zbawiciel.

Joseph Ratzinger zauważa, że to pozdrowienie anioła - będące sercem mariologii - nie jest przecież wymysłem ludzi, lecz Bożym objawieniem. Maryja jest utożsamiona z córą Syjonu, z ludem poślubionym przez Boga. Jako córa Syjonu jest Matką wszystkich wierzących. Wynika z tego ponadto brzemienny w konsekwencje wniosek eklezjologiczny. Wszystko, co Pismo Święte mówi o Kościele, w sensie typologicznym wolno odnieść także do Maryi. Tę zasadę można także odwrócić, tzn. tego, czym Kościół 
jest i powinien być, uczy się, spoglądając na świętą Dziewicę. Ona jest jego zwierciadłem, czystą miarą jego istnienia, ponieważ cała znajduje się w Bogu, jest przez Niego zamieszkiwana, a Boży Syn znajduje się w Niej. Bóg objawienia judeochrześcijańskiego nie jest abstrakcją, ale konkretną, rzeczywistą i historyczną osobą, udzielającą się przez osobę Rodzicielki z Nazaretu. Stąd Kościół jest także osobą otwartą na przyjęcie Boga i udzielającą Boga innym osobom, ale także światu ${ }^{35}$.

Tej typologicznej tożsamości Maryi i Syjonu poświęca więcej uwagi R. Laurentin, pogłębiając jej rozumienie ${ }^{36}$. My jednak przyjdźmy ponownie do pozdrowienia anioła "pełna łaski”. Grecki termin użyty na określenie „łaski” (charis) w swoim źródłosłowie ma związek ze słowem „radość” (chara) i „radować się” (chairein). Podkreślmy to ponownie: radość wypływa z łaski. Radość to coś nadprzyrodzonego, co "gra” nam w duszy. Trafnie napisze genialny teolog średniowieczny, Piotr Lombard (1100-116o lub 1164), że łaska i miłość są tym samym, tyle że miłością ,jest Duch Święty”. W najbardziej ścisłym sensie i znaczeniu łaska nie tyle pochodzi od Boga, ile jest samym Bogiem. Zwrot „Maryjo, jesteś pełna łaski” oznacza, że jest Ona osobą, która bez reszty otworzyła się na Boga, żyje w głębokiej, ontycznej relacji z Nim, jest napełniona Jego Duchem ${ }^{37}$.

2.Pozdrowienie Elżbiety - Łk 1, 42. Elżbieta, po zwiastowaniu anielskim, wpisuje się jako pierwsza z ludzi na listę tych, którzy wysławiają Maryję. Jej słowa w Ein Kerem do krewnej z Nazaretu: „Błogosławiona jesteś między niewiastami”, wypowiedziane z pewnością pod wpływem Ducha Świętego, prowadzą nas do źródła maryjnej czci. Jest to wskazanie samego Boga. Gdyby Kościół nie czcił Maryi, zaniedbywałby to, co mu zostało zlecone.

3.Proroctwo Maryi - Łk 1, 48. Jak już wyżej wspominaliśmy, słowa z Ewangelii św. Łukasza „Oto bowiem odtąd błogosławić mnie będą wszystkie pokolenia" to proroctwo i wręcz nakaz dla Kościoła po wszystkie czasy. To zdanie, pochodzące z Magnificat, które Maryja wypowiada pod wpływem Ducha Świętego, składając uwielbienie Jahwe, uważa się za fundament chrześcijańskiej pobożności maryjnej. Wynika z niego wyraźnie, że to nie nadgorliwość katolików czy emocjonalna pobożność prawosławnych

35 Por. J. Ratzinger, „Ty jesteś pełna łaski”. Elementy pobożności maryjnej, „Communio. Międzynarodowy Przegląd Teologiczny" 6 (2000), s. 140-141.

${ }^{36}$ Por. R. Laurentin, Struktur und Theologie der lukanischen Kindheitsgeschichte, Stuttgart 1967, s. 75-82.

37 Por. J. Ratzinger, „Ty jesteś pełna łaski”.., dz. cyt., s. 142-143. 
wytworzyły cześć do Najświętszej Maryi Panny. Błogosławienie Maryi nie jest zatem wymysłem starożytnego Kościoła czy też ludzi średniowiecza czynią oni wiernie to, co już u początków zostało im zlecone.

Kiedy Łukasz pisał ten tekst, żyło już drugie pokolenie chrześcijan. Oznacza to, że mimo iż do Kościoła przyłączyło się już sporo pogan, to dalej w przewadze byli judeochrześcijanie. Mimo wszystko nie wahali się oni szanować i kochać Maryi z Nazaretu, Matki ich Mesjasza. Wyrośli w żydowskiej rygorystycznej tradycji kultu tylko jednego i jedynego żywego Boga, rozumieli i praktykowali uwielbienie Matki Jezusa. Kardynał Ratzinger zauważa, że wyrażenie „wszystkie pokolenia” zaczynało napełniać się historyczną rzeczywistością. Możemy być spokojni, że Ewangelista nie przekazałby proroctwa Maryi, gdyby nie miało ono znaczenia lub wydawało się, że już jest spełnione. Proroctwo Maryi należało do tych istotnych elementów, które on przekazał „dokładnie”, aby wyznawcy Jezusa mieli do dyspozycji pewne i niezawodne wskazania (por. $Ł k 1,1-2)^{38}$.

4. Okrzyk anonimowej kobiety - Łk 11, 27. Drugie miejsce biblijne wzywające do czci Maryi to wypowiedź nieznanego autorstwa. Okrzyk kobiety z tłumu: „błogosławione łono, które Cię nosiło”, nic nie utracił na swojej aktualności, a nawet $\mathrm{z}$ czasem nabrał jeszcze większego ciężaru. Cześć maryjna zyskała bowiem swoje wyraźne odniesienie do Chrystusa. Nieustanne wysławianie Maryi w świetle Łukaszowej Ewangelii stanowi jeden z trwałych nurtów pierwotnej wspólnoty chrześcijan. A skoro jednym ze znamion Kościoła jest jego apostolskość, czyli trwanie w nauce apostołów, to również Kościół czasów dzisiejszych czy przyszłych żadną miarą nie może odstąpić od czci Najświętszej Maryi Panny. Gdyby wygasła w nas maryjna pobożność, oznaczałoby to odejście od biblijnego nauczania.

5. Poznanie Boga przez Maryję - Rz 1, 20. Ponieważ Boga nie poznajemy wprost i bezpośrednio, ale przez stworzenie, które wyszło z Jego ręki, to zbliżając się z miłością do Najświętszej Maryi Panny, przybliżamy się do Niego samego. Pismo Święte uczy: „Albowiem od stworzenia świata niewidzialne Jego przymioty - wiekuista Jego potęga oraz bóstwo - stają się widzialne dla umysłu przez Jego dzieła”. Boga poznajemy bliżej za pośrednictwem historii ludzkiej, w której On zdecydował się być obecny. Jak natura człowieka ujawnia się w jego relacjach z innymi, tak Bóg staje się widzialny i odkrywamy Jego naturę, kiedy docieramy do Abrahama, Mojżesza czy Józefa i Maryi. Oczywiście, nie odkrywamy Boga całkowicie ani nie

\footnotetext{
${ }^{38}$ Por. tamże, s. 138.
} 
jesteśmy w stanie zobaczyć Go w czystej postaci, niemniej poznajemy nie jakąś naszą ideę o Nim, ale Jego rzeczywiście w coraz lepszy sposób. Maryja jest jedną $\mathrm{z}$ osób, które w bardzo szczególny sposób były powiązane z Bogiem, dlatego - jak zauważa Ratzinger - nie oddajemy Mu właściwej czci, jeśli Ją pomijamy. „Gdybyśmy Ją odstawili na bok, zapomnielibyśmy o Nim coś, czego nie można zapomnieć [...] Jego «macierzyństwo», które w Matce Jego Syna objawia się w sposób bardziej czysty i bezpośredni niż gdziekolwiek indziej" ${ }^{39}$.

Podsumowując, tych pięć wzmiankowanych wyżej miejsc biblijnych stanowi dostateczne uzasadnienie maryjnej czci. Dlatego w żadnym wypadku kult maryjny nie może być postrzegany ani kwalifikowany jako zewnętrzny i emocjonalny przejaw religijności. Jawi się on wręcz jako Boży nakaz. Nie ma pełnej postaci Chrystusa ani Jego Kościoła bez mariologicznych i maryjnych odniesień.

\subsubsection{Wiara KościoŁa}

Maryjne lex credendi prowadzi do maryjnego lex orandi. Zasadę tę przypominają dwie papieskie adhortacje Pawła vi: Signum magnum oraz Marialis cultus. Lex orandi Kościoła stanowi zachętę do lex credendi i jego weryfikację.

Wiara Kościoła w historiozbawcze posłannictwo Matki Jezusa wyrasta z Bożego objawienia. To objawienie - analizowane i werbalizowane w świetle wiary - stanowi zasadniczy punkt odniesienia w uzasadnianiu kultu maryjnego. Chodzi tu przede wszystkim o Pismo Święte i Tradycję, które są pierwszorzędnym źródłem dla mariologii i maryjności ${ }^{40}$.

\subsection{Odnowa kultu maryjnego w świetle Marialis cultus}

W roku 1974, dziesięć lat po uchwaleniu konstytucji Lumen gentium, zawierającej w rozdziale viı mariologię Soboru Watykańskiego, papież Paweł vi opublikował adhortację apostolską Marialis cultus. Jest to najdonioślejsza w dziejach chrześcijaństwa wypowiedź Magisterium dotycząca kultu

\footnotetext{
39 Por. tamże, s. 139.

40 Por. T. Siudy, Źródła i podstawy kultu maryjnego, dz. cyt., s. 15-18.
} 
Najświętszej Maryi Panny w Kościele ${ }^{41}$. Dokument ten formułuje zasady i podaje wskazania praktyczne, zgodnie z którymi dokonać się winna odnowa kultu maryjnego.

We wstępie nawiązuje papież do soborowego postulatu odnowy liturgicznej, który znalazł odzwierciedlenie w konstytucji o liturgii Sacrosanctum concilium, pierwszym dokumencie uchwalonym przez Vaticanum II. Mowa w nim, że w ramach odnowy całej liturgii Kościoła należy dokonać odnowy również w dziedzinie kultu maryjnego. W mentalności ludzi współczesnych i we wrażliwości kulturowej społeczeństw dają się zauważyć zmiany i tendencje, które należy uwzględnić przy rozwijaniu i pogłębianiu czci oddawanej Maryi w Kościele.

W pierwszej części adhortacji Paweł vi rozważa miejsce Maryi w odnowionej liturgii Kościoła. Omawia poszczególne maryjne święta kalendarza liturgicznego, wspomina o miejscu, jakie poświęcają Maryi teksty liturgiczne, takie jak mszał, lekcjonarz, liturgia godzin. Ukazuje Najświętszą Maryję Pannę jako wzór Kościoła w zasłuchaniu się w słowo Boże, w modlitwie, w przekazywaniu światu Chrystusa, w gotowości do ofiary i w pobożności. Zasada mówiąca, że liturgia jest „złotą regułą pobożności chrześcijańskiej”, sprawdza się również w kulcie maryjnym.

Druga część adhortacji poświęcona jest teologicznym zasadom i szczegółowym wskazaniom dotyczącym odnowy kultu maryjnego. Z czterema zasadami odnowy tego kultu korespondują cztery drogi jego realizacji w posoborowym kontekście.

Z kolei trzecia część papieskiego dokumentu omawia Anioł Pański i Różaniec, dwie tradycyjne modlitwy maryjne, które w pełni odpowiadają sformułowanym uprzednio zasadom i opisanym drogom odnowy kultu maryjnego. Anioł Pański to przypomnienie centralnej tajemnicy wiary chrześcijańskiej - wcielenia Syna Bożego, a równocześnie nawiązanie do misterium paschalnego (męki, krzyża i zmartwychwstania Chrystusa). Modlitwa ta nie potrzebuje odnowy - „po wielu wiekach trwa jej moc i piękno, gdyż budowa jej jest prosta i zapożyczona z Pisma Świętego"42. Różaniec jest modlitwą na wskroś ewangeliczną. Stąd czerpie bowiem rozważane w nim tajemnice i główne formuły modlitewne: modlitwę, której nas nauczył Jezus

${ }^{41}$ Jak czcić Matkę Bożą? Adhortacja apostolska papieża Pawła VI „Marialis cultus” o należytym kształtowaniu i rozwijaniu kultu Najświętszej Maryi Panny, pr. zbior., przygot. do wyd. i wstęp S. C. Napiórkowski, Niepokalanów 1986.

${ }^{42}$ MC 41. 
Chrystus, pozdrowienie Anioła i błogosławieństwo Elżbiety. Jest modlitwą chrystologiczną, gdyż w jej centrum znajduje się tajemnica wcielenia Syna Bożego, do której nawiązują słowa Pozdrowienia Anielskiego. Różaniec przypomina główne tajemnice zbawienia dokonanego przez Jezusa Chrystusa. Jest to wreszcie modlitwa kontemplacji, w której rozważamy wielkie dzieła zbawcze Ojca i Syna, i Ducha Świętego. Bez kontemplacji modlitwie różańcowej grozi bezduszność. Nie można więc dopuścić, aby stała się ona bezmyślnym powtarzaniem formuł. Należy dołożyć wszelkich starań, aby prowadziła do „kontemplacji tajemnic życia Chrystusa, rozważanych jakby sercem Tej, która ze wszystkich była najbliższa Panu, i by otwarte zostały niezgłębione tych tajemnic bogactwa" ${ }^{43}$.

\subsubsection{Cztery zasady odnowy}

Odwołując się do treści papieskiej adhortacji, dokonajmy teraz prezentacji czterech zasad odnowy kultu maryjnego.

Pierwsza z nich to zasada trynitarna. Przedmiotem i celem kultu chrześcijańskiego jest Bóg w Trójcy Świętej, którego tajemnicę poznaliśmy przez Jezusa Chrystusa w Duchu Świętym. Ta prawda odróżnia kult chrześcijański od kultu Boga w innych wielkich religiach monoteistycznych. Oddając cześć człowiekowi, chrześcijaństwo czyni to tylko ze względu na Boga. Oddając cześć Maryi, należy więc podkreślać prawdę „o Bogu wielkim, który dzieli się ze stworzeniami swoją wielkością, o Bogu świętym, który dzieli się ze stworzeniami swoją świętością, o Bogu jedynie godnym czci, który dzieli się ze stworzeniami swoją chwałą". W rozwijaniu pobożności maryjnej podkreślać należy szczególną więź Maryi z Ojcem, Synem i Duchem Świętym. To ze względu na wcielenie Syna Bożego Bóg Ojciec wybrał Ją od wieków, a Duch Święty przyozdobił Ją niezwykłymi darami.

Zasada chrystologiczna przypomina, że w kulcie chrześcijańskim dominować musi Jezus Chrystus, przez którego Bóg objawił w pełni tajemnicę swego życia i zbawcze zamiary wobec człowieka. Kryterium kultu prawdziwie chrześcijańskiego jest umieszczenie Chrystusa w samym jego centrum. Nabożeństwa maryjne muszą zachować pełną chrystologiczną przejrzystość. Nikt tak głęboko jak Maryja nie wszedł w życie Chrystusa. Wraz z Synem stoi Ona w samym sercu historii odkupienia. Jeżeli w niektórych nabożeństwach Chrystus spychany jest na drugi plan, to takie formy pobożności potrzebują odnowy.

${ }^{43}$ MC 47. 
Zasada pneumatologiczna to druga reguła wynikająca wprost z zasady trynitarnej. Źródła objawienia podkreślają w wielu miejscach szczególny związek Ducha Świętego z Matką Syna Bożego. W najważniejszym momencie dziejów zbawienia Duch Święty połączył się z Maryją, co w konsekwencji stało się połączeniem Bóstwa z człowieczeństwem. Należy podkreślać ścisły związek Matki Syna Bożego z Osobą Ducha Świętego, którego dziełem jest nic tylko Jej macierzyństwo i uświęcenie, lecz także zgodnie z przekonaniem ojców i pisarzy Kościoła - Jej wiara, nadzieja, miłość, siła umacniająca Ją w spełnianiu woli Bożej i męstwo, dzięki któremu wytrwała pod krzyżem.

Zasada eklezjologiczna domaga się uwzględniania perspektywy eklezjalnej w rozwijaniu czci Matki Bożej. Chodzi tu o ukazanie miejsca, jakie zajmuje Ona w Kościele. Jest to miejsce szczególne, wyjątkowe, "najwyższe po Chrystusie i nam najbliższe" ${ }^{44}$. Maryja jest nie tylko Matką Kościoła, lecz także pierwszą chrześcijanką, najpiękniejszą cząstką Kościoła, wzorem wiary, nadziei i miłości oraz posłuszeństwa woli Bożej. Kościół zaś winien się stać przedłużeniem Jej macierzyńskiej troskliwości.

\subsubsection{Drogi odnowy}

Do powyższych zasad teologicznych Paweł vi w swojej adhortacji dołącza wskazania szczegółowe, nawiązujące do głównych tendencji nauczania soborowego. Dokument formułuje cztery takie wskazania, które określane są w polskiej literaturze mariologicznej jako drogi odnowy kultu maryjnego.

Biblijna droga odnowy zawiera w sobie postulat dowartościowania Pisma Świętego w kulcie maryjnym. Wzywa do większej troski o wierność jego orędziu. Odnowa biblijna współczesnego Kościoła musi objąć również dziedzinę mariologii. Chodzi o przeniknięcie i wypełnienie kultu maryjnego najważniejszymi treściami biblijnego orędzia.

Liturgiczna droga odnowy wzywa do podporządkowania czci oddawanej Matce Bożej zasadom liturgii Kościoła. Papież przestrzega przed nierozważnym znoszeniem praktyk religijnych, które należy uzgodnić z liturgią, a nie likwidować. Ich usunięcie stwarza bowiem próżnię, którą niełatwo jest wypełnić. Jednak nabożeństw maryjnych, jak godzinki czy różaniec, nie należy łączyć z mszą świętą. Liturgia jest też najlepszym wzorem modlitwy kierowanej razem z Maryją do Ojca przez Chrystusa w Duchu Świętym ${ }^{45}$.

\footnotetext{
44 KK 54.

${ }^{45}$ Por. MC 31.
} 
Ekumeniczna droga odnowy współbrzmi z jednym z najważniejszych znaków czasu, jakim jest dążenie chrześcijan do jedności. Cześć oddawana Maryi jest pomostem ku Kościołom Wschodu, odznaczającym się szczególną gorliwością w kulcie Bogarodzicy. Również teologowie anglikańscy przyznają, że Pismo Święte stanowi solidną podstawę kultu Matki Chrystusa i Jej miejsca w życiu chrześcijańskim. Nawet Kościoły powstałe w wyniku reformacji modlą się słowami Maryi, poświadczonymi przez Ewangelię. Papież przypomina apel Soboru o „unikanie wszelkiej przesady, która innych braci mogłaby wprowadzić w błąd co do prawdziwej nauki Kościoła katolickiego" ${ }^{46}$. Jak Maryja sprawiła swoją prośbą cud przemiany wody w wino, tak może w naszych czasach przyspieszyć chwilę, w której uczniowie Chrystusa znajdą doskonałą jedność w wierze.

Antropologiczna droga odnowy to apel o uwzględnianie w kulcie maryjnym osiągnięć nauk antropologicznych oraz warunków, w jakich żyje człowiek współczesny, jego niepokojów i lęków, jego sposobu wartościowania. Także człowiek dzisiejszy może i powinien odnaleźć w Maryi wzór do naśladowania. Winien podążać Jej drogą w całkowitym oddaniu się Chrystusowi i Jego dziełu, w otwarciu się na Bożego Ducha. Maryja jest wzorem do naśladowania dla wszystkich, szczególnie dla kobiet ${ }^{47}$.

Po omówieniu zasad i dróg odnowy Marialis cultus wskazuje na pewne niewłaściwości i błędy, które mogą się wkraść do praktyk pobożności chrześcijańskiej przy oddawaniu czci Najświętszej Maryi Pannie. W nawiązaniu do myśli Soborowej przestrzega papież zarówno przed przekraczaniem $w$ treści i formie kultu zasad zdrowej teologii maryjnej, jak i przed pomniejszaniem roli Maryi w życiu wspólnoty Kościoła. Niebezpieczeństwem dla właściwej czci Matki Chrystusa jest spotykana u niektórych wiernych „zwodnicza łatwowierność", prowadząca nierzadko do przeceniania praktyk zewnętrznych. Postawa ta połączona jest niekiedy z brakiem autentycznej gorliwości religijnej i wyraża się w obcej duchowi Ewangelii przesadnej uczuciowości. Budowanie pobożności maryjnej jedynie na uczuciu może sprawić, że stanie się ona mało owocna w praktyce chrześcijańskiego życia.

Przeciwdziałać należy ciągle powracającym tendencjom do szukania nowości i nadzwyczajnych wydarzeń czy też lekceważeniu prawdy historycznej na korzyść legendy lub fałszu. Kult maryjny musi być czysty, jeśli chodzi

\footnotetext{
${ }^{46}$ Por. KK 67.

47 Por. MC 34-37.
} 
o motywy - wszystko, co miałoby posmak szukania korzyści materialnej, winno być trzymane $\mathrm{z}$ dala od sanktuariów ${ }^{48}$.

\subsection{Liturgiczne miejsca i sposoby kultu}

Spróbujmy choćby pokrótce przedstawić teraz główne formy maryjnej czci, poczynając od liturgii kościelnych (uroczystości, świąt mniejszych, wspomnień lokalnych i partykularnych), przez całe bogactwo różnych form modlitwy wspólnotowej i prywatnej, aby skończyć na zasadniczych kierunkach maryjnej duchowości ${ }^{49}$.

\subsubsection{Uroczystości, święta i wspomnienia}

W adhortacji Marialis cultus Paweł vi, odwołując się do wskazań numeru 102 soborowej konstytucji o liturgii Sacrosanctum concilium, pisał:

Przed odnową liturgii rzymskiej trzeba było starannie na nowo opracować jej Kalendarz powszechny. Ten nowy układ - ponieważ został dokonany w tym celu, by obchód dzieła zbawczego w ustalone dni odpowiednio został uwidoczniony przez rozdzielenie na roczny cykl całej tajemnicy Chrystusa, od Wcielenia poczynając aż po oczekiwanie Jego chwalebnego przyjścia - sprawił, że wspomnienie Matki Bożej zostało włączone w roczny cykl tajemnic Syna w bardziej organiczny sposób i w ściślejszym powiązaniu z tymi tajemnicami ${ }^{50}$.

W dalszych części tego dokumentu (numery 3-14) papież rozważa szczegółowiej adwentową pobożność ludową i cześć maryjną, zwłaszcza drugą i ostatnią fazę Adwentu, a także uroczystość Niepokalanego Poczęcia, następnie zaś okres Bożego Narodzenia z uwzględnieniem uroczystości Bożej Rodzicielki i Świętej Rodziny. Omawia kolejno Zwiastowanie i Wniebowzięcie. W tych czterech maryjnych uroczystościach o najwyższej randze liturgicznej znajdują się zasadnicze prawdy dotyczące pokornej Służebnicy Pańskiej.

${ }^{48}$ Por. mC 38. Zob. także S. Budzik, Maryja $w$ tajemnicy Chrystusa i Kościoła, dz. cyt., S. $139-146$.

49 Wyczerpująco na ten temat pisze S. De Fiores, Maria. Madre di Gesù. Sintesi stolico-salvifica, dz. cyt., s. 236-303.

50 MC 2. 
Adhortacja poświęca także uwagę mniejszym maryjnym świętom. Paweł vi ukazuje te, które upamiętniają zbawcze wydarzenia, podkreślające ścisłą więź Maryi z Synem:

Są nimi: święto Narodzenia Najświętszej Maryi Panny (8 września); święto Nawiedzenia (31 maja) - jego liturgia czci Najświętszą Maryję Pannę noszącą w łonie Syna, która jednak odwiedza Elżbietę, by służyć jej pomocą swej miłości i obwieścić miłosierdzie Boga Zbawiciela; wspomnienie Matki Bolesnej (15 września), które daje sposobność żywego przypomnienia najważniejszej i jakby rozstrzygającej chwili historii zbawienia, a także sposobność uczczenia „Matki współcierpiącej z Synem”, przy którym stała, gdy był wywyższony na krzyżu. Trzeba również zwrócić uwagę na święto z dnia 2 lutego, któremu przywrócono nazwę Ofiarowanie Pańskie, by dokładnie uchwycić bardzo bogatą treść w nim zawartą, mianowicie połączone wspomnienie Syna i Matki. Jest to bowiem uroczysty obchód tajemnicy zbawienia dokonanego przez Chrystusa, z którym Najświętsza Dziewica najściślej się zespoliła jako Matka cierpiącego Sługi Jahwe, jako wykonawczyni zadania powierzonego dawnemu Izraelowi i jako wzór nowego ludu Bożego, który wśród wiary i nadziei ustawicznie jest doświadczany cierpieniami i prześladowaniami ${ }^{51}$.

Odnowiony kalendarz rzymski wskazuje również na maryjne wspomnienia lokalne oraz zawarte w kalendarzach partykularnych. Paweł vi zauważa, że wspomniane uroczystości opierają się na motywach kultu lokalnego, który został rozszerzony na cały Kościół powszechny. Odwołuje się do następujących wspomnień lokalnych: 11 lutego - Najświętszej Maryi Panny z Lourdes, sobota po drugiej niedzieli po Zesłaniu Ducha Świętego - Niepokalanego Serca Najświętszej Maryi Panny, 16 lipca - Najświętszej Maryi Panny z Góry Karmel, 5 sierpnia - poświęcenie bazyliki Najświętszej Maryi Panny, 7 października - Najświętszej Maryi Panny Różańcowej, 21 listopada - Ofiarowanie Najświętszej Maryi Panny ${ }^{52}$.

\subsubsection{Maryja w Ordo Missae}

W liturgii mszalnej cześć oddawana Najświętszej Maryi Pannie zajmuje ważne miejsce. Na odrębne studium zasługuje porównanie liczby i charakteru maryjnych wspomnień w przedsoborowym porządku w mszale

\footnotetext{
51 MC 7.

${ }^{52}$ Por. MC 8.
} 
Piusa v z posoborową praktyką, przykładowo w modlitwach kanonów eucharystycznych. Omawiając cześć oddawaną Najświętszej Maryi Pannie w mszale po reformie liturgicznej Soboru Watykańskiego II, należy wskazać na zmiany tekstów prefacji oraz zmianę w obrębie Kanonu rzymskiego i w nowych formach modlitw eucharystycznych ${ }^{53}$.

Mszał Pawła vi - ogłoszony w 1970 roku, czterysta lat po mszale Piusa v, stanowiącego owoc reform Soboru Trydenckiego, zawiera nie tylko jedną, pierwotną maryjną prefację. Do świąt maryjnych, które nie posiadają własnej prefacji, doszła prefacja inspirowana tekstem Magnificat, która może być wykorzystywana przy różnych świętach. Święta Pańskie z dnia 25 marca oraz 2 lutego, które dawniej klasyfikowano jako święta maryjne, również szczycą się własnymi prefacjami. Także uroczystości ku czci Najświętszej Maryi Panny, Niepokalane Poczęcie (8 grudnia) i Wniebowzięcie (15 sierpnia), ubogacone są szczególnymi prefacjami.

Z kolei zmiana w Kanonie rzymskim, która otrzymała nazwę Pierwszej Modlitwy Eucharystycznej, odnosi się pośrednio do maryjnej czci. Lista świętych skróciła się, ale Maryja jest wymieniana jako pierwsza w ich społeczności. W anamnetycznej części II Modlitwy Eucharystycznej oraz w IV Modlitwie Eucharystycznej wśród dzieł zbawczych Boga jest wymienione wcielenie Jego Syna z Maryi Dziewicy. II Modlitwa wskazuje przez to na swoją podstawę, jaką była Eucharystia Hipolita, a IV Modlitwa sięga do modelu Kościołów Wschodnich. Wolno zauważyć, że w posoborowej liturgii Ordo Missae cześć oddawana Najświętszej Maryi Pannie wyrażona w modlitwach eucharystycznych osiągnęła swoje wyraźniejsze kształty.

W omawianej adhortacji biskup Rzymu zaznacza:

w modlitwach eucharystycznych w jakiejś niezwykłej harmonii z liturgiami wschodnimi znajduje się starożytne wspomnienie Najświętszej Maryi Panny. W prastarym Kanonie rzymskim, w którym Bożą Rodzicielkę czci się słowami pełnymi bogatej treści i religijnego zapału, czytamy: „Zjednoczeni z całym Kościołem, ze czcią wspominamy najpierw pełną chwały Maryję, zawsze Dziewicę, Matkę Boga i Pana naszego, Jezusa Chrystusa". Także w Modlitwie eucharystycznej III, niedawno wprowadzonej, pragnienie proszących z usilnym błaganiem, by wraz z Matką mogli uczestniczyć w dziedzictwie synów, jest wyrażone następująco: „Niech On nas uczyni wiecznym darem dla Ciebie (Ojcze), abyśmy

${ }^{53}$ Por. B. Kleinheyer, Maria in der Liturgie, [w:] Handbuch der Marienkunde, Bd. I, dz. cyt., s. $469-476$. 
otrzymali dziedzictwo z wybranymi Twoimi, przede wszystkim z Najświętszą Dziewicą, Bogurodzicą Maryją". To codzienne wspomnienie, jako że zostało ono umieszczone w samym środku Boskiej Ofiary, winno się uważać za szczególny wyraz czci, jaką Kościół okazuje „Błogosławionej przez Najwyższego”’54.

Nie można także pominąć obecności imienia Maryi w innych tekstach mszalnych. Należy wskazać na rozszerzony embolismus do modlitwy Ojcze nasz. Ponadto w spowiedzi powszechnej święci z Maryją nie są już adresatem wyznania grzechów, ale są przywoływani do wstawiennictwa przed Bogiem.

\subsubsection{Maryjne msze święte i nieszpory}

W siedemnaście lat po ogłoszeniu mszału Pawła vi ${ }^{55}$, który zastąpił mszał trydencki z 1570 roku, opublikowano kolejny, będący zbiorem mszy świętych o Najświętszej Maryi Pannie ${ }^{56}$. Dołączono do niego lekcjonarz, deklarując, iż obie księgi stanowią rodzaj aneksu do rzymskiego mszału Pawła vi. Wiele Kościołów lokalnych dość szybko przetłumaczyło Collectio Missarum de Beata Maria Virgine na swoje języki ojczyste. Także wierni Kościoła katolickiego w Polsce mogą z niego korzystać.

Msze maryjne kompleksowo ukazują wyraźne maryjne akcenty w liturgii eucharystycznej. Już nawet powierzchowny ogląd otwierającego wersetu, kolekty, liturgii słowa, psalmu responsoryjnego czy pozostałych części mszy świętej ukazuje wierzącym udział Maryi w odkupieńczym planie Boga Ojca i spełnieniu go przez Jezusa Chrystusa. Nie do przeoczenia jest również modlitwa eucharystyczna - stanowiąca istotę wydarzenia liturgii eucharystycznej - gdzie jest miejsce dla Najświętszej Maryi Panny. W tym kontekście warto zwrócić uwagę także na pieśni maryjne. Formularz mszy świętych maryjnych zawiera propozycje pieśni na komunię świętą.

Cześć oddawana Maryi wyrażana jest także modlitwą nieszporów. Większość mszalików czy modlitewników zawiera nieszpory na maryjne uroczystości i święta. Ta popołudniowa modlitwa Kościoła już w swej pierwszej części - w hymnie - kieruje pozdrowienie do Bożej Rodzicielki. Po psalmach następuje liturgia słowa, w ramach której odczytywany jest fragment Nowego Testamentu odnoszący się do Maryi. Nieszpory niosą ze sobą

\footnotetext{
54 MC 10.

55 Missale Romanum, editio typica, Città del Vaticano 1970.

${ }^{56}$ Collectio Missarum de Beata Maria Virgine, Città del Vaticano 1987.
} 
Magnificat - wspaniałą modlitwę uwielbienia Boga, jaką wyśpiewuje Maryja. Często antyfona odznacza się maryjnym charakterem. Kolejną część nieszporów stanowią prośby, które wypowiada Kościół do Ojca Niebieskiego za pośrednictwem Matki Jego Syna. Końcowa oratio także wspomina Maryję. Całość wieńczy maryjna antyfona, przez którą zgromadzenie zwraca się nie bezpośrednio do Boga, ale do Maryi ${ }^{57}$.

\subsubsection{Lekcjonarz mszalny i liturgia godzin}

W omawianym dokumencie Ojciec Święty Paweł vi kieruje uwagę wiernych także na teksty lekcjonarza mszalnego oraz liturgii godzin, w których znalazło się więcej miejsca dla osoby Maryi i Jej funkcji w odkupieńczym i zbawczym dziele Jezusa Chrystusa. W posoborowym odnowionym rycie rzymskim do lekcjonarza mszalnego dołączono bowiem znacznie więcej tekstów biblijnych. Dzięki zwiększonej liczbie czytań mszalnych w trzyletnim cyklu (rok A, B, i C) ukazano całą historię zbawienia. Tym samym lepiej można zgłębiać tajemnicę Boskiego Odkupiciela i Jego Matki. Obecna forma lekcjonarza zawiera większą liczbę czytań ze Starego i Nowego Testamentu, odnoszących się także do samej Najświętszej Dziewicy. Jednakże ów ilościowy przyrost oparto na krytycznej ocenie, gdyż zatrzymano tylko te czytania, które z powodu oczywistości swej treści lub na podstawie starannej egzegezy, popartej wskazaniami Urzędu Nauczycielskiego lub solidnej tradycji, uznano za mające znaczenie maryjne. Te czytania wykorzystywane są nie tylko w maryjne święta, lecz także czytane przy wielu innych okolicznościach, jak np. w niektóre niedziele roku liturgicznego, przy sprawowaniu obrzędów sakramentów lub sakramentaliów, czy wreszcie $\mathrm{z}$ okazji przykrych lub radosnych wydarzeń, które spotykają wierzących ${ }^{58}$.

Adhortacja Marialis cultus odnosi się również do maryjnych elementów liturgii godzin. Odnowiony brewiarz dostarcza wspaniałych dowodów czci dla Najświętszej Maryi Panny. Znajdujemy je w hymnach, wśród których nie brak świetnych pomników literatury, jakim jest np. modlitwa Dantego Alighieri do Dziewicy, w antyfon ach - stanowiące liryczne błaganie zamykające bieg codziennej modlitwy (np. Pod Twoją obronę), w prośbach modlitwy porannej i nieszporów, w których modlący bardzo często z ufnością uciekają się do Matki pełnej miłosierdzia, a także

${ }^{57}$ Por. A. Jilek, Marienmessen und Marienvespern, [w:] Handbuch der Marienkunde, Bd. I, dz. cyt., s. 504-525.

${ }_{58}^{8}$ Por. MC 12. 
w licznych czytaniach - będących zapisem pobożności maryjnej całych wieków chrześcijaństwa ${ }^{59}$.

Podsumowując ten punkt, odwołajmy się do papieskiej uwagi Pawła vi. Przegląd odnowionych ksiąg liturgicznych skłania do radosnego stwierdzenia, że posoborowy ruch liturgiczny pozwala spojrzeć na Maryję Dziewicę w tajemnicy Chrystusa. Jest to spojrzenie przyznające Jej - zgodnie z tradycją - szczególne miejsce w kulcie chrześcijańskim. Maryja jako święta Boża Rodzicielka i Towarzyszka Odkupiciela zajmuje to miejsce zarówno na Wschodzie, jak i na Zachodzie. Najznakomitsze i najwspanialsze przejawy pobożności względem Najświętszej Dziewicy rozwinęły się przecież w ramach właśnie samej liturgii albo zostały włączone w jej całość:

Kult oddawany obecnie przez Kościół powszechny Najświętszej Bożej Rodzicielce wypływa i przedłuża oraz nieustannie powiększa tę cześć, jaką w każdym czasie okazywał Jej Kościół, bardzo starannie badając prawdę i zawsze troszcząc się o godność form. Z niezmiennego źródła tradycji, która przecież jest żywa dzięki nieustannej obecności Ducha Świętego i dzięki ustawicznemu słuchaniu Bożych słów, Kościół dzisiejszy czerpie zasady i motywy oraz bodźce do pielęgnowania kultu, jaki oddaje Najświętszej Dziewicy. Liturgia, uzyskująca zatwierdzenie i umocnienie ze strony Urzędu Nauczycielskiego, pozostaje najwznioślejszym świadectwem, a także najtrwalszym pomnikiem tej żywej tradycji ${ }^{60}$.

\subsection{Modlitewne formy czci}

Ze względu na nieprawdopodobnie dużą liczbę i wiele rodzajów modlitw do Najświętszej Dziewicy trudno jest uszeregować je czy też sklasyfikować w sposób odpowiedzialny. W dziejach Kościoła rozwinęły się one w najróżniejszych formach. Przyjmując jednak pewne uproszczenia, zaprezentujemy następujące grupy modlitw do Najświętszej Maryi: modlitwy biblijne, hymny, antyfony i apele ( $w$ tym jasnogórski), litanie, tytuły i wezwania, pieśni, akty zawierzenia, a także peregrynację kopii cudownego obrazu jasnogórskiego. Naturalnie poniższa prezentacja nie rości sobie pretensji ani do wyczerpującego omówienia tych form czci Matki Jezusa, ani do ich

\footnotetext{
59 Por. MC 13.

${ }^{60}$ MC 15.
} 
całościowego ujęcia. Zostawiamy szerokie pole do uwzględnienia jeszcze innych sposobów kultu Matki Jezusa.

\subsubsection{Cztery modlitwy biblijne}

Najpierw należy wspomnieć o tzw. biblijnych modlitwach maryjnych. Zaliczamy do nich przede wszystkim Magnificat i Zdrowaś Maryjo. Tekst Magnificat odnajdziemy w całości w Ewangelii św. Łukasza (Łk 1, 46-55). W Piśmie Świętym znajdują się natomiast jedynie podstawowe części Ave Maria, którymi są pozdrowienie anielskie (Łk 1, 28: „Bądź pozdrowiona, pełna łaski, Pan z Tobą") i słowa Elżbiety w trakcie spotkania z Maryją (Łk 1, 42: „Błogosławiona jesteś między niewiastami i błogosławiony owoc Twojego łona"). Te ewangeliczne fragmenty były powtarzane przez wiele wieków. W XII wieku do tych wersetów z Nowego Testamentu zaczęto dodawać imię Jezus. W ten sposób Chrystus stał się centrum tej maryjnej modlitwy. Trzecia część Zdrowaś Maryjo powstała dopiero w XIV wieku, kiedy w Europie rozprzestrzeniały się choroby zakaźne, zwłaszcza dżuma. W nowo dodanych słowach modlitwy znalazł się ślad grozy owych dni: „teraz i w godzinę śmierci”. Ostatecznie w 1566 roku papież Pius v zalecił umieścić te dodatkowe słowa maryjnej modlitwy w rzymskim brewiarzu i tym samym taką postać Ave Maria uczynił oficjalną modlitwą Kościoła.

Z modlitwami Zdrowaś Maryjo i Ojcze nasz łączy się różaniec, który okazuje się przez to modlitwą w większej części wyraźnie zakorzenioną biblijnie, choć mimo to na ogół uważany jest za typową maryjną modlitwę ludową. Różaniec powstał około 1400 roku. Jest to zasługa dwóch kartuskich zakonników: Adolfa z Essen (ok. 1350-1439) i Dominika z Prus.

Łacińska nazwa rosarium pochodzi od wyrazu rosa (róża) i oznacza ogród różany. Rosarium Beatae Mariae Virginis to zatem dosłownie ogród różany Błogosławionej Maryi Dziewicy. Polski termin „różaniec”, czyli różany wieniec, wieniec $\mathrm{z}$ róż, powstał już w średniowieczu. Odmawianie różańca porównywano wówczas z ofiarowaniem Matce Jezusa wieńców $\mathrm{z}$ róż symbolizujących Zdrowaś Mario, przeplatanych białymi liliami symbolizującymi Ojcze nasz.

Początkowo różaniec funkcjonował jako Psałterz Najświętszej Maryi Pan$n y$, aby w późnym średniowieczu stać się samodzielną modlitwą. W bulli Ea quae z 9 maja 1479 roku papież Sykstus IV polecił codzienne odmawiać różaniec. W 1508 roku do modlitwy Zdrowaś Mario dodano zakończenie: „Święta Maryjo, Matko Boża, módl się za nami”. Z kolei po Soborze Try- 
denckim Pius v 17 września 1569 roku zatwierdził różaniec maryjny bullą Consueverunt Romani Pontifices, zastępując nazwę Psałterz Najświętszej Maryi Panny nazwą Różaniec Najświętszej Maryi Panny, określając podział na 3 części (radosną, bolesną, chwalebną) i ustalając ostatecznie tajemnice różańcowe. Papież ten zwrócił uwagę, że tajemnice różańcowe należy medytować i wprowadził odmawianie jeden raz Wierze i trzy razy Zdrowaś na początku różańca. W bulli tej pojawiło się również wezwanie kończące modlitwę Zdrowaś, po słowie „Jezus”: „Święta Maryjo, Matko Boża, módl się za nami grzesznymi teraz i w godzinę śmierci naszej. Amen".

Współczesny kształt różańca zawdzięczamy św. Janowi Pawłowi II, który rozszerzył go o część czwartą. W ogłoszonym 16 października 2002 roku liście apostolskim Rosarium Virginis Mariae przedstawił on tajemnice światła jako propozycję. Ta papieska inicjatywa została szybko przyjęta i rozpropagowana w całym Kościele.

Różaniec jest w swej istocie maryjną medytacją Chrystusa i Jego odkupieńczego dzieła. Jest jak najbardziej kontemplacją wraz z Maryją ewangelicznych tajemnic Jezusa. Jak podkreślił papież: „Kontemplacja ma charakter hebrajskiej pamiątki (hebr. zakar), poprzez którą zbawcze wydarzenia nie należą tylko do «wczoraj»; są także «dniem dzisiejszym» zbawienia" ${ }^{\text {"1. }}$

W tymże dokumencie papież z Polski uczy także:

Różaniec, właśnie wychodząc z doświadczenia Maryi, jest modlitwą wyraźnie kontemplacyjną. Pozbawiony tego wymiaru, okazałby się wyzuty ze swej natury, jak podkreślał Paweł vi: „Jeśli brak kontemplacji, różaniec upodabnia się do ciała bez duszy i zachodzi niebezpieczeństwo, że odmawianie stanie się bezmyślnym powtarzaniem formuł, oraz że będzie w sprzeczności z upomnieniem Chrystusa, który powiedział: «Na modlitwie nie bądźcie gadatliwi jak poganie. Oni myślą, że przez wzgląd na swe wielomówstwo będą wysłuchani» (Mt 6, 7). Różaniec bowiem $z$ natury swej wymaga odmawiania w rytmie spokojnej modlitwy i powolnej refleksji, by przez to modlący się łatwiej oddał się kontemplacji tajemnic życia Chrystusa, rozważanych jakby sercem Tej, która ze wszystkich była najbliższa Panu, i by otwarte zostały niezgłębione tych tajemnic bogactwa" ${ }^{32}$.

${ }^{61}$ Jan Paweł II, List apostolski Rosarium Virginis Mariae do biskupów, duchowieństwa i wiernych o różańcu świętym [dalej: RVM], 13 .

${ }^{62}$ RVM 12. 
Po Magnificat, Zdrowaś Maryjo i różańcu do zbioru maryjnych modlitw biblijnych należy dodać jeszcze czwartą, a jest nią Anioł Pański. Modlitwa Angelus ma swoją długą historię. Jej powstanie datuje się na okres od xI do XIV wieku i wiąże ze świeckim zwyczajem końca średniowiecza, aby o zmierzchu dzwonić w naczynia do przechowywania ognia. Wraz z rozwojem miast i drewnianej zabudowy wzrastało bowiem niebezpieczeństwo pożarów. Na głos wieczornego dzwonu, którym dawano znak gaszenia paleniska we wszystkich obejściach, ludzie kończyli dzień, wysławiając Najświętszą Maryję Pannę. Tak wykształcił się też zwyczaj odmawiania Zdrowaś Maryjo na dźwięk dzwonu. Na początku xıII wieku papież Grzegorz IX zarządził, aby Pozdrowienie Anielskie odmawiać rano i wieczorem, zawsze na dźwięk dzwonu. Potwierdził to Synod w Kolonii w 1279 roku. W rozpowszechnienie modlitwy Angelus duży wkład wniósł także zakon franciszkanów. W 1262 roku św. Bonawentura jako przywódca duchowych synów św. Franciszka nakazał zakonnikom odmawiać rano i wieczorem trzy Zdrowaś Mario. Tradycja odmawiania Angelus rozpowszechniła się zatem w XVI wieku w całym zachodnim chrześcijaństwie. Z czasem zaczęto odmawiać Anioł Pański także rano, aby uczcić Maryję jako „Poranną Jutrzenkę”. Natomiast zwyczaj odmawiania Angelus w południe wprowadził papież Kalikst III w 1456 roku, aby wybłagać u Matki Bożej ratunek dla oblężonego przez Turków Belgradu, który był ostatnią naddunajską twierdzą broniącą drogi do serca Europy ${ }^{63}$.

Dzięki przekazom radiowym i telewizyjnym większości chrześcijan świata Anioł Pański kojarzy się z publiczną audiencją papieską w środę i w niedzielę. Zwłaszcza niedzielna modlitwa następcy św. Piotra gromadzi dzisiaj tysiące wiernych. W swojej refleksji na temat tej modlitwy we Wrocławiu Jan Paweł II zwrócił uwagę na jej głębię eucharystyczną:

Wszyscy znamy tę modlitwę. Wiemy, że przypomina nam ona scenę Zwiastowania. Anioł Pański zwiastował Pannie Maryi i poczęła z Ducha Świętego. Chwila Zwiastowania jest równocześnie momentem dziewiczego poczęcia Syna Bożego. Tak więc ta maryjna modlitwa, którą odmawiamy trzykrotnie w ciągu dnia, przypomina nam tę wielką tajemnicę Wcielenia. Bądź pozdrowiona, pełna łaski, Pan z Tobą, i błogosławiony jest owoc Twojego łona (Łk 1, 28. 42) [...] Modlitwa Anioł Pański odsłania nam swoją głębię eucharystyczną. Chrystus

${ }^{63}$ Por. F. Courth, Marianische Gebetsformen, [w:] Handbuch der Marienkunde, Bd. I, dz. cyt., s. 526-549. 
w ofierze ołtarza, pod postacią chleba i wina daje nam za pokarm Ciało i Krew, które za sprawą Ducha Świętego dała Mu Jego Matka, Maryja. Bóg Ojciec, wybierając Maryję na Matkę swojego Jednorodzonego Syna, w sposób szczególny związał Ją z Eucharystią ${ }^{64}$.

Wolno ostatecznie zauważyć, że wszystkie cztery biblijne modlitwy - Magnificat, Zdrowaś Maryjo, Różaniec, Anioł Pański - jakkolwiek nazywane maryjnymi, mają charakter zdecydowanie teocentryczny. To Bóg jest ich pierwszym i podstawowym punktem odniesienia. Cechuje je poprawna struktura słowno-teologiczna. Kto zatem odmawia te modlitwy, ten, wraz z Maryją, czci Trójjedynego Boga. Maryja okazuje się najwłaściwszą Nauczycielką naszej wiary w Ojca, w Ducha Świętego i w Jezusa jako Mesjasza.

\subsubsection{Hymny, antyfony, apele}

Maryja jest czczona również w hymnach. Większość tego typu utworów powstawała z okazji uroczystości, świąt bądź wspomnień. Ich wielopostaciowej strukturze formalnej odpowiada bogactwo treściowe. Może to być chwała i dziękczynienie składane Bogu Ojcu za wybranie Maryi, może być uwielbienie Ducha, że uczynił Maryję Matką Bożego Syna, może być wysławianie Syna, który z Maryi stał się człowiekiem. Maryjne hymny są także często bezpośrednim Jej przywołaniem, aby wstawiała się za nami u swego Syna.

Najpiękniejszym hymnem na cześć świętej Rodzicielki jest naturalnie Akathistos. Bez wątpienia jest on szczytem literatury maryjnej. Powstał między v a vi wiekiem. Akathistos śpiewany jest po dziś dzień w liturgii Kościoła wschodniego, ale przeżywa swój renesans również na Zachodzie. Trzeba przyznać, że Kościół Wschodu wniósł olbrzymi wkład w tworzenie maryjnych hymnów. Zapisane w języku greckim (w tradycji bizantyjskiej), ormiańskim, syryjskim, arabskim, koptyjskim oraz innych stanowią trwałe świadectwo nieustannego wychwalania Maryi już od początków chrześcijaństwa. W tym kontekście ogromne znaczenie ma także muzyka cerkiewna. Chóry prawosławne - wykonując dzieła zarówno anonimowych kompozytorów (np. śpiew grecki, kijowski czy neumatyczny), jak i utwory najwybitniejszych twórców muzyki cerkiewnej (np. Maksym Berezowski, Siergiej Rachmaninow, Piotr Czajkowski, Nikołaj Rimski-Korsakow) wprost prześcigają się w uwielbianiu Bożej Matki.

${ }^{64}$ Jan Paweł II, Rozważanie przed modlitwa „Anioł Pański” [przemówienie wygłoszone we Wrocławiu podczas pielgrzymki do Ojczyzny w 1997 roku], 1.06.1997. 
Również poezja i muzyka tworzona na Zachodzie mogą się poszczycić licznymi odniesieniami do Maryi z Nazaretu. Hymny, układane najpierw w języku łacińskim, a następnie w językach narodowych, były i są często recytowane przez wiernych. Najczęściej anonimowego autorstwa, znalazły zastosowanie tak w uroczystej liturgii, jak i w prywatnej pobożności. Któż nie zna hymnu „Ave maris stella, virgo singularis, inter omnes mitis czy też Salve Regina [...]. O clemens, o pia, o dulcis virgo Maria"? ${ }^{65}$.

Hymny maryjne tworzono zarówno w przestrzeni kościelnej, liturgicznej, jak i w sferze profanum, w muzyce i w poezji. Powstawały też na żyznej glebie pobożności ludowej. Polskim wiernym najbardziej znany jest hymn "Zawitaj Pani świata, niebieska Królowa, Witaj, Panno nad panny, gwiazdo porankowa!", popularnie nazywany godzinkami. Za przykład poetycki niech posłuży choćby Hymn na dzień Zwiastowania NMP, który wyszedł spod pióra Adama Mickiewicza:

Pokłon przeczystej rodzicy!

Nad niebiosa twoje skronie,

W gwiaździstych wieńcach płonie,

Jehowie na prawicy.

Ze współczesnych dzieł ku czci Najświętszej Maryi Panny należy przywołać Hymny Maryjne Romana Brandstaettera (1906-1987). Te przepełnione polskością wołania do Matki Bożej są przykładem niezwykle wysokiego kunsztu poetyckiego.

Istnieje również ogromna liczba maryjnych antyfon, wywodzących się nierzadko z Pisma Świętego Starego i Nowego Testamentu. Ich autorzy często pochodzący ze środowisk klasztornych - pozostają w wielu wypadkach anonimowi. Od połowy Xv wieku zaczęły się pojawiać pierwsze polskie przekłady łacińskich antyfon maryjnych. Do bardziej znanych tłumaczy należą ks. Franciszek Ksawery Głodkiewicz oraz abp Ignacy Hołowiński. Błogosławionemu Władysławowi z Gielniowa przypisuje się stworzony już w języku polskim hymn:

Zdrowaś, my k'Tobie wołamy,

Wszystką pewność w Tobie mamy

Grzeszni synowie Jewini,

${ }^{65}$ Por. F. Courth, Marianische Gebetsformen, dz. cyt, s. 550-554. 
Racz prosić za nasze winy

Chrysta Nazareńskiego!

Piękną cechą charakterystyczną polskiej pobożności maryjnej są wieczorne modlitwy apelowe, a zwłaszcza apel jasnogórski. O godzinie 21.00 na Jasnej Górze i w innych miejscowościach (zarówno w kraju, jak i za granicą) łączących się w modlitwie z tym maryjnym sanktuarium odbywa się nabożeństwo apelu jasnogórskiego. Jego zasadnicza struktura jest następująca: śpiew Bogurodzica, antyfona apelowa „Maryjo, Królowo Polski, jestem przy Tobie, pamiętam, czuwam” (śpiewana trzykrotnie, na kilka melodii), krótka medytacja, odmówienie jednej tajemnicy różańca, antyfona Pod Twoją obronę. Na prośbę ostatnich papieży (od Jana XxIII) do apelu dołącza się Zdrowaś Maryjo w intencji Ojca Świętego. Na zakończenie ma miejsce błogosławieństwo udzielane przez obecnego biskupa lub kapłana przewodniczącego apelowi. Na koniec śpiewa się pieśń maryjną, przeważnie $Z$ dawna Polski Tyś Królową. Poza jasnogórskim sanktuarium nabożeństwo to przyjmuje niekiedy odmienne formy ${ }^{66}$.

\subsubsection{Litanie, tytuły i wezwania}

Skarbiec chrześcijańskiej duchowości dysponuje sporą liczbą wezwań do Matki Bożej, zebranych w formie litanii. Do stosunkowo znanych za-

${ }^{66}$ Według o. dra Józefa Płatka osppe geneza tego nabożeństwa łączy się z pilotem Władysławem Polesińskim, sceptycznym wobec spraw wiary. W 1934 w trakcie próbnego lotu niespodziewanie usłyszał on rozkaz: „Zniż lot, ląduj”. Kiedy wylądował, nastąpiła eksplozja jego samolotu. Była godzina 21.0o. W tej właśnie godzina żona polecała go Matce Bożej. Kapitan Polesiński nawrócił się. Kierując się wdzięcznością, założył wśród oficerów organizację Krzyż i Miecz, której członkowie codziennie o godz. 21.00 meldowali się na apel przed Matką Bożą Jasnogórską. W historii wykształcania się modlitwy apelowej istotna jest także decyzja ks. bpa Józefa Sebastiana Pelczara z dnia 21.05.1910, który w przededniu drugiej koronacji wizerunku Królowej Polski diademami podarowanymi przez Ojca Świętego Piusa x polecił, aby we wszystkich kościołach jego przemyskiej diecezji od godz. 21.00 przez piętnaście minut biły dzwony. Z czasem praktyka apelu stawała się coraz popularniejsza, zwłaszcza po aresztowaniu prymasa Wyszyńskiego. W czasie przygotowań do trzechsetlecia obrony Jasnej Góry, Wielkiej Nowenny (1957-1966) oraz trwającej peregrynacji kopii cudownego obrazu Matki Bożej Jasnogórskiej nabożeństwo apelowe nabrało szczególnego rozmachu i zasięgu. Godny odnotowania przyczynek do rozsławienia apelu jasnogórskiego wniósł Jan Paweł II, który w trakcie swoich apostolskich podróży do Polski modlitwę tę ubogacał dodatkowym rozważaniem. Święty papież z Polski modlił się do Maryi słowami Apelu wielokrotnie także poza Jasną Górą. Dziś codziennie Apel jest transmitowany przez różne rozgłośnie radiowe, zwłaszcza Radio Maryja i Telewizję Trwam. 
liczane są: Litania Loretańska, Litania do Niepokalanego Serca, Litania do Królowej Apostołów, Litania do Królowej Aniołów, Litania do Matki Bożej Bolesnej, Biblijna Litania do Maryi, Litania do Królowej Pustelników (paulińska), Litania do Matki Bożej Szkaplerznej, Litania do Matki Bożej Saletyńskiej, Litania Dominikańska. Zwieńczeniem modlitwy litanijnej jest często zwyczajowo odmawiana specyficzna modlitwa (np. modlitwa św. Bernarda). Litanie to przepiękne modlitwy, w których odniesienia biblijne przeplatają się z tradycją kościelną, z wydarzeniami i kontekstem historycznym, a ubogacone są ludową pobożnością i folklorem. Maryja jest w nich wysławiana i wychwalana, proszona o orędownictwo i wstawiennictwo.

Nie sposób oczywiście wymienić wszystkich tytułów i wezwań, jakimi w ciągu wieków lud chrześcijański wysławia Najświętszą Maryję Pannę. Zostały one już częściowo zebrane właśnie w litaniach. Jako uzupełnienie mogą służyć tytuły kościołów, kaplic, bractw, związków, unii czy innych zrzeszeń chrześcijańskich, które za patronkę przyjmują Matkę Jezusa. Niekiedy patronat ten łączy się z innym - przykładowo świątynia jest dedykowana Jezusowi w jakimś Jego przymiocie lub świętemu, a parafia poświęcona Maryi, lub odwrotnie, np. kościół jest pod wezwaniem św. Marcina, a parafia poświęcona Matce Bożej Nieustającej Pomocy. Trudno także znaleźć zakon, zgromadzenie czy stowarzyszenie życia konsekrowanego, które nie czciłoby Bożej Rodzicielki w jakimś szczególnym tytule, wiążącym się ze specyfiką i charyzmatem tejże wspólnoty.

\subsubsection{Pieśni}

Chrześcijaństwo, zwłaszcza katolickie i wschodnie, może się poszczycić dużą liczbą pieśni maryjnych, co poniekąd świadczy o ortodoksji, gdyż bez Maryi nie byłoby Chrystusa i - jak dodaje eklezjologia katolicka - bez Niej nie ma też pełnej postaci Kościoła.

Treść tych pieśni odzwierciedla przeżycia i potrzeby danego Kościoła partykularnego. Ponieważ Polska przez pewien okres swoich dziejów doznawała ucisku ze strony sąsiadów, w polskich pieśniach religijnych, a zwłaszcza maryjnych, znajduje się nierzadko nuta melancholii, tęsknoty za wolnością i pokojem. Podobną sytuację - uwarunkowaną kontekstem historycznym - potwierdzają teksty pieśni katolickich Węgrów, Chorwatów czy prawosławnych Greków.

Listę polskich pieśni maryjnych otwiera Bogurodzica. Nie znamy jej autora ani dokładnej daty powstania. Przypuszczalnie wywodzi się ona 
ze środowisk zakonnych, a jej narodziny przypadają na przełom XIII i XIV wieku. Z pewnością była śpiewana przed bitwą pod Grunwaldem, a $z$ czasem stała się nieformalnym hymnem narodowym.

Od połowy XV wieku w pieśniach zaczyna dominować kult Matki Boskiej Bolesnej. Wyrażał się on w planktach, czyli w pełnych żalu polskich rozważaniach męki Pańskiej. Wyrażają one boleść i smutek Matki Zbawiciela. Sekwencja mszalna Stabat Mater dolorosa z XII wieku, opisująca cierpienia Matki Chrystusa, ma swoje polskie odpowiedniki, np. Stała Matka żałościwa wedle krzyża boleściwa (kancjonał Walentego z Brzozowa, 1554). Dużym powodzeniem cieszyła się pieśń Omni die dic Mariae (Codziennie, duszo, chwal Maryję). Była to ulubiona pieśń św. Kazimierza Jagiellończyka. Po jego śmierci włożono mu jej tekst do trumny.

W dobie szerzących się w Europie chorób zakaźnych w XVII wieku śpiewano pieśni: Gwiazdo morza oraz Gwiazda niebieska śmierć wykorzeniła. W książeczce ks. Stanisława Brzeżańskiego pt. Owczarnia $w$ dzikim polu zachowały się trzy pieśni maryjne: Witaj, Królowo nieba; Witam Cię, witam, Królowo niebieska oraz Bądź pozdrowiona, Panienko Maryja, wszyscy mieszkańcy dworu niebieskiego. Już wtedy zaczął się szerzyć w Polsce kult niepokalanego poczęcia Maryi Panny.

Z kolei przełom wieków XVIII i XIX okazuje się dość ubogi w maryjną twórczość pieśniową. Wyjątek to pieśni staniąte cki e. Kompozytorzy polscy na początku XIX wieku ulegali duchowi muzyki świeckiej, bardziej koncertowej i operowej niż liturgicznej. Odrodzenie przyszło przez działalność stowarzyszenia cecyliańskiego, którego członkowie wywodzili się z bawarskiego środowiska szkół muzycznych w Ratyzbonie i w Monachium. Wpisał się w ten ruch ks. Michał Marcin Mioduszewski, który zebrał pieśni tradycyjne i opracował Śpiewnik kościelny (1838) z 60 pieśniami maryjnymi. Materialnym poświadczeniem maryjnej pobożności jest całkiem pokaźna liczba kościelnych śpiewników. Wskażmy tu popularny śpiewnik dla młodzieży, opracowany przez ks. Jana Siedleckiego CM (Kraków 1878), w którym umieszczono 30 pieśni o Matce Bożej. Natomiast w wydaniu jubileuszowym (1928) jest już ich $92^{67}$. Zjawiskiem szczególnym jest ukazanie się Śpiewnika maryjnego Jana Szyca i Leona Świerczka (zawierającego - poza mszą ku czci Matki Bożej Nieustającej Pomocy oraz mszą

${ }^{67}$ Por. J. Buczek, Bóg Ojciec a Maryja w pieśniach zamieszczonych w „Śpiewniku kościelnym“ ks. Jana Siedleckiego, sm 1 (1999) nr 3, s. 81-104. 
maryjną - 280 maryjnych pieśni kościelnych oraz 70 pozakościelnych (np. pątniczych i przygodnych $)^{68}$.

\subsubsection{Akty zawierzenia}

Pięknym wyrazem maryjnego kultu są rozliczne akty zawierzenia. Już tytuły „Królowa” czy „Pani” odnoszone do Maryi i określenia „sługa” i „niewolnik” do wiernych odsłaniają praktykowane od pierwszych wieków Kościoła maryjne formy zawierzenia. Początki takich aktów, w których Maryja nazywana jest Królową, sięgają III wieku. Najstarszy przykład tego zwyczaju znajdujemy u Orygenesa, a dalsze u Efrema, u Romana Melodosa (ok. 490 ok. 560), u Maksyma Wyznawcy (ok. 580-662), aby wymienić przynajmniej najwcześniejszych świadków.

Interesujący przyczynek do określenia Maryi jako Królowej pojawia się w aktach poświęcenia Jej kościołów i klasztorów wczesnego średniowie$\mathrm{cza}^{69}$. Obok zawierzenia modlitwy te zawierają jednocześnie hołd, relację poddaństwa i opieki. W takim nastawieniu św. Stefan Węgierski powierzył swoje królestwo Matce Bożej jako patronce. Nie tylko zatem średniowieczne zakony, jak np. cystersi czy premonstratensi, lecz także bractwa i związki świeckie obierają sobie Maryję za Patronkę. Paulini czy dominikanie podkreślają to jeszcze mocniej, gdyż do tekstu swoich ślubów zakonnych wprowadzają imię Maryi. Patrząc historycznie na rozwój modlitw zawierzenia się Maryi, należy przywołać siedemnaste stulecie z kongregacjami maryjnymi. Sodaliści po raz pierwszy wypowiadają consecrare, poświęcając się Maryi. Początkowo termin ten postrzegany jest jako równoważnik klasycznych pojęć: se offerre, tradere, commendare, devovere. Jednakże $\mathrm{z}$ czasem czasownik consecrare zaczyna być używany coraz częściej w sensie refleksyjnym. Stosuje się go jako hasło właściwe dla tego aktu szczególnego oddania się. Do opus operatum sakramentalnej konsekracji dochodzi opus operations poświęcenia się. Wykształca się formuła liturgiczna. Najstarszym tego przykładem jest Rituale z Combrai z 1600 roku. Dla członków maryjnych kongregacji „poświęcenie się” oznacza osobiste naśladowanie cnót Maryi i działalność apostolską.

Modlitwa poświęcenia się Najświętszej Maryi Pannie z naciskiem położonym na służbę wobec Niej otrzymuje we francuskiej szkole duchowości szczególny akcent, a mianowicie poświęcenie się Maryi charakteryzuje

${ }^{68}$ Por. S. Ziemiański, Polskie pieśni maryjne, „Posłaniec” 2009, maj, s. 30-31.

69 Por. F. Courth, Marianische Gebetsformen, dz. cyt., s. 557-564. 
poświęcenie się Jej sercu. Skutecznym promotorem tego nabożeństwa staje się przede wszystkim św. Jan Eudes ze swoim modlitewnikiem La coeur admirabile de la Mère de Dieu (1681), w którym zbliża się do idei - którą propagował już Egbert z Schönau (ok. 1120-1184) - najściślejszego połączenia serca Maryi z sercem Jezusa.

Prezentując w zarysach rozwój aktu poświęcenia się Najświętszej Maryi Pannie jako wyrazu czci wobec Niej, nie można pominąć znaczącego wkładu zakonu jezuitów. Modlitwy poświęcenia się Matce Bożej miały u nich wyraźne piętno rycerskie, były powiązane ze średniowieczną mistyką i z maryjną duchowością szkoły francuskiej, będącej wówczas pod wpływem kard. Pierre’a de Bérulle’a. Te elementy dojdą szczególnie do głosu w doskonałym nabożeństwie Ludwika Marii Grignion de Montforta. Drugie pod względem wielkości swoje dzieło Tajemnica Maryi ten francuski święty również poświęca Matce Jezusowej.

W Traktacie o doskonałym nabożeństwie do Najświętszej Maryi Panny Grignion de Montfort uczy:

Bóg pragnie, by Jego Najświętsza Matka była obecnie więcej znana, bardziej kochana i bardziej czczona niż kiedykolwiek. Nastąpi to niewątpliwie, jeśli wybrani rozpoczną za łaską Ducha Świętego tę wewnętrzną i doskonałą praktykę, którą im zaraz przedstawię. Wtedy ujrzą, o ile wiara na to pozwala, tę piękną Gwiazdę Morza, by pod Jej kierunkiem mimo burz i rozbojów morskich dopłynąć szczęśliwie do portu. Wtedy poznają wspaniałość tej Królowej i poświęcą się całkowicie Jej służbie jako poddani i niewolnicy z miłości.

Według św. Ludwika poświęcenie się Maryi jest w swej istocie poświęceniem się Jezusowi. Maryja dąży przede wszystkim do tego, aby tych, którzy się Jej zawierzają, upodobnić do swojego Syna. Jesteśmy w takim stopniu rzeczywistymi synami i córkami Maryi, w jakim upodobniamy się do Jezusa. Maryja już od początku czytelnie wskazała drogę upodobniania się do Niego, mówiąc: „Uczyńcie wszystko, co On wam powie” (J 2, 5). Grignion de Montfort wyraża przekonanie, że poświęcić się Maryi oznacza żyć w uzależnieniu od Niej, aby być prowadzonym najkrótszą drogą do Zbawiciela. Dlatego należy codziennie przebywać i wszystkie swoje działania prowadzić w obecności Maryi. W konsekwencji Jej natura z każdym dniem będzie coraz mocniej oddziaływać na naturę Jej dzieci. I jak Matka cieszy się, widząc dzieci przypominające coraz bardziej Jej Syna - zauważa św. Ludwik - tak 
Jezusa napełnia radość, kiedy odkrywa stopniowo u nich charakterystyczne cechy Przenajświętszej Dziewicy ${ }^{70}$.

W działalności Kościoła w Polsce - jeśli chodzi o akty zawierzenia - wymieńmy choćby śluby króla Jana Kazimierza (Lwów 1656), akt poświęcenia się Narodu Niepokalanemu Sercu Maryi (Jasna Góra, kard. August Hlond, 1946), akt poświęcenia się wspólnot zakonnych Niepokalanemu Sercu Maryi (Jasna Góra, 1946), Jasnogórskie Śluby Narodu Polskiego (kard. Stefan Wyszyński, Jasna Góra 1956), Milenijny Akt Oddania Polski w Macierzyńską Niewolę Maryi Matki Kościoła (Jasna Góra 1966), Akt Zawierzenia Jana Pawła II (1979), Akt Zawierzenia Młodzieży Matce Bożej przez Ojca Świętego Jana Pawła II (Jasna Góra 1991), modlitwy zawierzenia Niepokalanej według św. Maksymiliana Kolbego czy też liczne formy aktów wynagrodzenia i poświęcenia się Matce Bożej Fatimskiej. Można także wspomnieć maryjną duchowość bł. Jerzego Matulewicza. Ten odnowiciel zakonu marianów akcentował więź z Maryją jako dar Boży, ufność w Jej opiekę oraz Jej naśladowanie ${ }^{71}$.

Znaczące są również oficjalne pisma Episkopatu Polski, w których biskupi zwracają się do wiernych $\mathrm{z}$ apelem o oddanie się lub zawierzenie Maryi. Wydawnictwo Michalineum opublikowało dwutomowy zbiór listów pasterskich Episkopatu Polski z ostatniego półwiecza. Razem to przeszło 2500 stron tekstów ${ }^{72}$. Możemy wyliczyć 14 znajdujących się tam dokumentów tego typu: Apel Episkopatu Polski do modlitwy o oddanie świata Maryi, Matce Kościoła (1974); W jedności z Ojcem Świętym Pawłem vi powierzamy Maryi Matce Kościoła chrześcijaństwo i współczesny świat (1976); Odnawiamy i wypełniamy Jasnogórskie Śluby Narodu (1977); Dlaczego oddaliśmy Polskę w macierzyńska niewolę Maryi, Matki Kościoła (1978); O oddaniu Polski w niewole Maryi za Kościół Święty (1978); Ponowne oddanie parafii Maryi Matce Kościoła przed 6oo-leciem Jasnej Góry (1978); O osobistym oddaniu się w macierzyńska niewole Maryi za Kościół (1979); Biskupi zapraszaja wiernych do osobistego oddania się Matce Bożej za Kościół (1979); Z okazji ponowienia papieskiego aktu zawierzenia (1981); Na dzień zawierzenia Polski NMP (1993); List pasterski Episkopatu Polski na 3o. rocznice polskiego

70 Por. F. Courth, Marianische Gebetsformen, dz. cyt., s. 557-566.

${ }^{71}$ Por. J. Kumala, Maryja w życiu i duchowości bł. Jerzego Matulaitisa-Matulewicza (18711927), sM 12 (2010) nr 3-4, s. 216-226.

${ }^{72}$ Zob. Listy Pasterskie Episkopatu Polski 1945-20oo, red. P. Libera, A. Rybicki, S. Łącki, t. III, Marki 2003. 
Milenium. Modlitwa o pomoc w wypetnieniu jasnogórskich ślubów narodu polskiego (1977); Akt oddania parafii w macierzyńska niewole Maryi, Matce Kościoła. Za wolność Kościoła (1978); Papieski akt zawierzenia Matce Bożej $(1981 \text { i 1996 })^{73}$.

\subsubsection{Peregrynacje jasnogórskiego wizerunku}

W połowie xx wieku Kościół katolicki w Polsce przygotowywał się do obchodów jubileuszu tysiąclecia przyjęcia chrztu. Prymas Polski, kard. Stefan Wyszyński, przebywający w więzieniu (1953-1956), opracował plan duchowych rekolekcji narodu przed millennium. Wówczas zrodziła się myśl nawiedzenia wszystkich polskich parafii i diecezji przez kopię cudownego obrazu jasnogórskiego. Nawiedzenie miało zmobilizować społeczeństwo do odnowy moralnej. Peregrynacja, rozumiana jako ingres Maryi w codzienne trudne sprawy Polaków, miała być istotną częścią przygotowania do jubileuszu tysiąclecia chrztu. Inicjator peregrynacji, prymas Wyszyński, napisał w Komańczy (w czwartym i ostatnim miejscu swego internowania) tekst Jasnogórskich Ślubów Narodu i program Wielkiej Nowenny. Ostateczna decyzja w sprawie nawiedzenia zapadła 11 kwietnia 1957 roku na 45. Konferencji Plenarnej Episkopatu Polski.

W archikatedrze warszawskiej św. Jana Chrzciciela kopia cudownego obrazu 29 sierpnia 1957 roku rozpoczęła swą pielgrzymkę po Polsce, którą zakończyła 12 października 1980 roku, kiedy to odbyło się na Jasnej Górze uroczyste nabożeństwo dziękczynne za łaski nawiedzenia. W ciągu ponad 23 lat pielgrzymowania Maryja w kopii jasnogórskiego wizerunku nawiedziła przeszło 8 tysięcy kościołów i kaplic na terenie 7150 parafii. Po kilku latach przerwy Episkopat Polski postanowił powtórzyć wielką akcję peregrynacji zwanej nawiedzeniem. Zachęcały do tego wspaniałe owoce, które ona przyniosła. Stąd w Drohiczynie 5 maja 1985 roku rozpoczęła się druga taka peregrynacja, która trwa nadal.

Czas nawiedzenia i przygotowań to czas wzmożonego wysiłku duszpasterskiego w skali całych diecezji: to programy duszpasterskie, nabożeństwa przygotowawcze, rekolekcje, misje, sympozja, nabożeństwa samej peregrynacji, głoszone wtedy słowo, wiele modlitwy liturgicznej w świątyniach i kaplicach, w domach rodzinnych, wiele modlitwy prywatnej, zwiększona

${ }^{73}$ Por. W. Siwak, Maryja w tajemnicy Chrystusa w polskim kulcie maryjnym, [w:] Recepcja „Marialis cultus” w Polsce. Materiały z ogólnopolskiego sympozjum mariologicznego, Licheń, 12-13 marca 2004 roku, red. J. Kumala MIC, Licheń Stary 2004, s. 75-148. 
obecność wiernych w kościołach i korzystanie z sakramentu spowiedzi świętej oraz Eucharystii. Nie sposób wymienić ogromu duchowej pracy podejmowanej przez poszczególnych chrześcijan, różnych zobowiązań wewnętrznych, moralnych zmian życia osobistego, rodzinnego i zawodowego. Wyrażają one ogromną skalę skutków działania Maryi, prowadzącej wiernych do Boga.

\subsection{Przepowiadanie (homilie, kazania, katechezy)}

Niezwykle istotnym elementem w szerzeniu maryjnej czci jest głoszenie Ewangelii, które przybiera różne formy. Przepowiadanie maryjne w podstawowych przejawach to homilia, kazanie i katecheza. Na przepowiadanie należy spojrzeć przynajmniej z dwóch perspektyw: po pierwsze, jest ono przekazem i nauczaniem maryjnej wiedzy i pobożności („wiara rodzi się ze słuchania"), a po drugie, samo wsłuchuje się w Lud Boży, ubogaca się nim i z niego czerpie.

$\mathrm{Na}$ polskim rynku wydawniczym istnieje ogromna liczba publikacji z dziedziny teologii pastoralnej, obejmującej kaznodziejstwo i katechezę, gdzie często pojawiają się tematy maryjne. Wiele propozycji maryjnych kazań i homilii oferują czasopisma: „Biblioteka Kaznodziejska” (Poznań), „Materiały Homiletyczne” (Kraków), „Współczesna Ambona” (Kielce), jak również szereg innych periodyków, broszur okolicznościowych i książek. W świetle soborowych wskazań autorzy, ukazując przymioty Maryi, odnoszą je do Chrystusa i do Kościoła. Ukazują często także Jego Matkę w odniesieniu do lokalnej historii, zwyczaju czy folkloru. Wydaje się, że na ogół w polskim przepowiadaniu kult Maryi nie rywalizuje z Chrystusową chwałą, a właściwie ujęty staje się inspiracją i pomocą w kierunkowej soborowej ewangelizacji. Właściwie rozumiana cześć oddawana Najświętszej Maryi Pannie nie jest wartością samą w sobie, lecz ma przecież w konsekwencji prowadzić do zjednoczenia z Jej Bożym Synem. Nie ma przesady w stwierdzeniu, że w homiliach i kazaniach głoszonych między Odrą a Bugiem Matka Jezusa doznaje należnej czci. Duszpasterze z racji liturgicznego święta czy wspomnienia albo poświęcają całe homilie Maryi, albo - co wstępuje częściej - kończąc przepowiadanie, zwracają się wprost do Maryi, sławiąc Ją i prosząc o orędownictwo.

Jak w przypadku kazań i homilii dysponujemy szeregiem publikacji, tak i w katechezie mamy wiele pozycji ujawniających obecność Maryi. 
Potwierdzają to bibliografie katechetyczna za lata $1945-1995^{74}$ oraz za lata 1996-2000 ${ }^{75}$. Do wprowadzania elementów czci w katechezie zachęcają specjalistyczne czasopisma katechetyczne, jak np. „Katecheta”, „Formacja Katechetów”, „Biuletyn Katechetyczny”, „Horyzonty Wiary” czy „Głos Katechety" ${ }^{\prime \prime}$. W tej mierze wiele zależy także od osobistej inicjatywy i nastawienia danego katechety czy katechetki.

\subsection{Maryjne sanktuaria i pielgrzymowanie}

W naszym kraju znajduje się 185 sanktuariów z obrazem (bądź figurą) koronowanym oraz $385 \mathrm{z}$ obrazem niekoronowanym. Ta liczba jest wymownym świadectwem, jak mocno w polską pobożność wpisane są praktyki oddawania czci Bożej Rodzicielce. Sanktuaria stanowią niezbędny czynnik właściwego kształtowania autentycznego kultu maryjnego. W sanktuarium spotykają się elementy wartościowe i fałszywe. Zadaniem duszpasterzy jest, aby te pozytywne przyjąć, rozwinąć, umocnić, dowartościować, a negatywne zmieniać, zawsze pamiętając, aby podjęte działania nie prowadziły do niszczenia pobożności, ale ją ubogacały i pogłębiały. Sanktuarium ma st wa r z a ć przestrzeń dla zdrowych form pobożności ludowej, a zarazem sprzyjać oczyszczaniu tych, które uległy deformacji ${ }^{77}$.

Oprócz Jasnej Góry do innych znacznych sanktuariów maryjnych w Polsce z koronowanym obrazem lub figurą należy zaliczyć takie jak: Górka Klasztorna (Łobżenica) w Wielkopolsce z roku 1079 roku, Ludźmierz na Podhalu (1234), Krzeszów na Dolnym Śląsku (z xıII wieku), Bardo Śląskie - z figurą z XII wieku, Kalwaria Zebrzydowska (xviı wiek), Staniątki pod Krakowem, Leśniów (Żarki) - figura z XIV wieku, Licheń Stary

\footnotetext{
${ }^{74}$ Por. Bibliografia katechetyczna 1945-1995, oprac. R. Murawski, przy współpr. R. Czekalskiego i J. Tochmańskiego, Warszawa 1999, s. 160.

${ }^{75}$ Por. Bibliografia katechetyczna 1996-20oo, oprac. R. Czekalski, R. Murawski, Warszawa 2002, s. 68-69.

${ }^{76}$ Por. W. Siwak, Maryja w tajemnicy Chrystusa w polskim kulcie maryjnym, dz. cyt., s. 75-

77 Por. J. Kumala, Znaczenie sanktuarium maryjnego dla pobożności ludowej, [w:] Maryjne orędzie z Gietrzwałdu. Materiały z sympozjum mariologicznego Gietrzwałd, 13-15 września 2002 roku, red. J. Jezierski, K. Brzozowski, T. Siudy, Częstochowa-Gietrzwałd 2003, s. 129-145 (Biblioteka Mariologiczna, 3); por. także Z. J. Jabłoński, Recepcja nauki mariologicznej Soboru Watykańskiego II $w$ polskich sanktuariach, SM 16 (2014) nr 1-4, s. 211-265.
} 148. 
(przełom xx i xxı wieku), Skępe z figurą z xv wieku, Gietrzwałd (koło Olsztyna), Święta Lipka i Stoczek Warmiński, Sulisławice - obraz z Xv wieku, Gostyń - obraz z xvi wieku, a także Kodeń, Leśna Podlaska, Lublin-Latyczów, Gidle i Charłupia Mała.

Z kolei rangą światowych sanktuariów cieszą się takie miejsca poświęcone Maryi, jak: Fatima w Portugalii, Lourdes i La Salette we Francji, Ostra Brama w Wilnie na Litwie, Guadalupe w Meksyku, Knock w Irlandii, Loretto i Syrakuzy we Włoszech, Montserrat w Hiszpanii, Einsiedeln w Szwajcarii, Mariazell w Austrii, Altötting w Niemczech, Banneux w Belgii, Medjugorie w Bośni i Hercegowinie, Bystrzyca w Chorwacji, Marianka i Lewocza na Słowacji. Wydaje się, że nie ma takiego kraju na świecie zamieszkałego przez katolickich chrześcijan, w którym nie istniałoby maryjne sanktuarium.

Z tymi cudownymi miejscami natężonej modlitwy wiąże się pielgrzymowanie, które przybiera najprzeróżniejsze formy. Czciciele Matki Jezusa udają się do miejsc naznaczonych Jej niezwyczajną obecnością. W sposób wyraźny kult maryjny kwitnie na pielgrzymkach, a zwłaszcza na pielgrzymkach pieszych do rozlicznych dekanalnych, diecezjalnych, krajowych lub międzynarodowych sanktuariów maryjnych. Do tych miejsc, gdzie oddaje się Maryi szczególną cześć, gdzie znajduje się Jej cudowny obraz lub figura, chrześcijańscy pątnicy udają się przez cały rok, a przede wszystkim w okresie letnim. Do maryjnych sanktuariów przybywają nie tylko zwykli wierni, lecz także koronowane głowy państw, prezydenci i premierzy oraz papieże. Do głównego sanktuarium na polskiej ziemi Ojciec Święty Jan Paweł II przybywał sześciokrotnie, odbywając osiem podróży do naszego kraju (z wyjątkiem 1995 i 2002 roku). Matkę Bożą Jasnogórską nawiedził też Benedykt XVI w 2006 roku, a papież Franciszek w 2016 roku $^{78}$.

Teologia nie jest zatem tylko słowem o Bogu, lecz także słowem samego Boga. Dlatego w procesie budowania wiary posoborowa mariologia coraz więcej uwagi zwraca też i na duchowość. Wzorem Dziewicy z Nazaretu, która „zachowywała wszystkie te sprawy i rozważała je w swoim sercu”, nie wolno zaniedbywać uświęcenia człowieka, które dokonuje się poprzez modlitwę i życie sakramentalne ${ }^{79}$.

${ }^{78}$ Por. S. C. Napiórkowski, Sanktuaria maryjne $w$ służbie pojednania, jedności i pokoju, [w:] Nosicielka Ducha, Pneumatofora. Materiały z Kongresu Mariologicznego, Jasna Góra, 18 23 sierpnia 1996 r., red. J. Wojtkowski, S. C. Napiórkowski, Lublin 1998, s. 371-384.

79 Por. M. Chmielewski, Implikacje posoborowej mariologii dla duchowości katolickiej w Polsce, sM 16 (2014) nr 1-4, s. 154-170. 


\subsection{Kultura i sztuka o Maryi}

Cześć do świętej Dziewicy znajduje również swój przebogaty wyraz w muzyce, o czym już po części wspominaliśmy (w punkcie Hymny, antyfony, apele). Z obszaru zagadnienia czci Najświętszej Maryi Panny rozumianego ściśle jako rodzaje modlitw umknęło jeszcze wiele innych przejawów ludzkiej aktywności. A ponieważ wiele z nich naznaczonych jest jakąś specyficzną formą kultu Matki Bożej, to należałoby jeszcze uwzględnić z pewnością takie dziedziny, jak poezja i literatura, film i teatr, musicale, architektura, rzeźba i malarstwo. Są to wyzwania dla całego zespołu badaczy, a owoce ich pracy zajęłyby wiele tomów. Stąd w niniejszej książce nie podejmujemy się ukazania tego wielowątkowego bogactwa maryjnej kultury i sztuki, a zaledwie na nie wskażemy.

Natomiast dłużej zatrzymamy się za chwilę przy obrazach maryjnych, które nie tylko stanowią serca wielu maryjnych sanktuariów, nie tylko zdobią setki muzeów, lecz znajdują się także prawie w każdym mieszkaniu na świecie, gdzie spowija je modlitwa i gdzie żyją naśladowcy Jezusa. Dlatego następny rozdział poświęcimy wyłącznie ikonicznym przedstawieniom Matki Bożej.

\subsection{Struktury naukowe}

Kolejnym elementem wpływającym na sposób oddawania czci Maryi są środowiska naukowe, prowadzące długoletnią i usystematyzowaną teologiczną refleksję nad maryjnymi prawdami wiary, nad samym zjawiskiem kultu maryjnego i jego treścią. Te struktury zajmują się również popularyzacją teologicznej nauki o Maryi. Dużą rolę odgrywają tu wydziały teologii wyższych uczelni. Niewątpliwie od strony naukowej pierwsze miejsce w modelowaniu kultu maryjnego należy przyznać właśnie tym instytucjom. Warto wskazać na wykłady, programy badań, tytuły realizowanych prac naukowych, na organizowane konferencje, sympozja, warsztaty, panele, na publikacje. Od strony naukowej istotny wkład w mariologię i kult maryjny wnoszą pracownicy katedr mariologii, eklezjologii, liturgiki, pastoraliści i homileci. 


\subsubsection{Ośrodki naukowe i centra formacji}

Poza naukowymi strukturami uniwersyteckimi mapę ośrodków, mających wpływ na kształt czci do świętej Dziewicy w naszym kraju, ubogacają centra duchowości. Jest ich sporo, jeśli nie zapomni się uwzględnić wielu punktów formacji diecezjalnej, zakonnej czy instytutów życia konsekrowanego. Aktualnie wiodącymi są Centrum Formacji Maryjnej „Salvatoris Mater" w Licheniu, które od 1999 roku wydaje godny uwagi kwartalnik „Salvatoris Mater”, franciszkańskie centrum formacji Rycerstwa Niepokalanej oraz Instytut Maryjno-Kolbiański „Kolbianum” w Niepokalanowie. Pewną rolę odgrywają także specjalistyczne biblioteki maryjne działające w ramach Jasnogórskiego Instytutu Maryjnego w Częstochowie. Wśród katolickich chrześcijan maryjną cześć i teologię popularyzują też ośrodki duchowości i nauki przez liczne rekolekcje, dni skupienia, konferencje, sympozja, seminaria, kursy specjalistyczne. Publikują książki, artykuły, materiały formacyjne i inną literaturę mariologiczną i maryjną. Inspirują i promują tematykę kultu oraz wiedzy o Bożej Rodzicielce w szerokim zakresie.

\subsubsection{Polskie Towarzystwo Mariologiczne}

Prezentując ośrodki duchowości i nauki kształtujące polską pobożność maryjną, należy ponadto wymienić Polskie Towarzystwo Mariologiczne. Zostało one powołane stosunkowo niedawno, bo w 1999 roku, uchwałą 298. Konferencji Plenarnej Episkopatu Polski. Dekret erekcyjny Towarzystwa wraz z zatwierdzeniem jego statutów wydał 15 marca 1999 roku kard. Józef Glemp.

Statutowe cele Towarzystwa to: działalność naukowa na rzecz rozwoju mariologii; popularyzacja wiedzy mariologicznej, działalność na rzecz należytego kształtowania duchowości i kultu maryjnego. Cele te Towarzystwo realizuje przez organizowanie kongresów i sympozjów krajowych i międzynarodowych, organizowanie spotkań studyjnych i formacyjnych oraz działalność wydawniczą ${ }^{80}$.

Polskie Towarzystwo Mariologiczne zorganizowało samodzielnie oraz współorganizowało wiele ogólnopolskich sympozjów mariologicznych: w Częstochowie 6-8 września 1999 roku na temat: „Trójca Święta a Maryja”; w Niepokalanowie 27-28 października 2000 roku na temat: „Mariologia na przełomie wieków"; w Licheniu 26-27 października 2001 roku na temat:

${ }^{80}$ Por. Statut Polskiego Towarzystwa Mariologicznego, art. 7, sM 1 (1999) nr 2, s. 460. 
„Przez Jezusa do Maryi”; w Gietrzwałdzie 13-15 września 2002 roku na temat "Maryjne orędzie z Gietrzwałdu” (wraz z Zakładem Teologii Dogmatycznej i Fundamentalnej Uniwersytetu Warmińsko-Mazurskiego w Olsztynie i kustoszem sanktuarium); w Krakowie 24-25 kwietnia 2003 roku pod hasłem „Odkrywanie różańca” (wraz z Katedrą Mariologii Wydziału Teologicznego Papieskiej Akademii Teologicznej) ${ }^{81}$.

${ }^{81}$ Por. W. Siwak, Maryja w tajemnicy Chrystusa w polskim kulcie maryjnym, dz. cyt., s. 138141. 


\section{Artyzm i transcendencja maryjnych obrazów}

Mariologia integralna, a zwłaszcza w obszarze czci Maryi, winna odważnie sięgnąć do świętych obrazów. Materialny wizerunek Najświętszej Maryi Panny w dobie Internetu, w którym tak znaczącą rolę odgrywają symbol, znak i obraz, jawi się jako wielka szansa i (nowy) sposób ewangelizacji. Ikona maryjna nie tylko jest bowiem czynnikiem jednoczącym chrześcijan, lecz także przyciągając estetycznie, prowadzi do Boga osoby spoza Kościoła. Piękno Maryi w świętym obrazie może się stać dobrym środkiem komunkowania sakralności również dla chrześcijan oziębłych w wierze, a nawet i dla osób obojętnych religijnie. Estetyka i kultura będą doskonałymi nośnikami wartości duchowych dla zsekularyzowanego człowieka. Via pulchritudinis którą sygnalizował już bł. Paweł vi - jawi się jako pionierskie zadanie dla mariologów. Symfonia teologiczna tak bardzo potrzebuje dziś nośników piękna. Dlatego sztuka nie może być wykluczana, gdyż „droga piękna” okazuje się współczesnym sposobem na uwiarygodnienie mówienia o Maryi i oddawania Jej czci'.

\subsection{Maryja i Jej piękno w ewangelizacji}

$\mathrm{Z}$ ankiet przeprowadzonych przez prof. van der Vana w pięciu parafiach w Nijmegen (Holandia), Arnheim (Holandia), Ottawie (Ontario, Kanada)

\footnotetext{
${ }^{1}$ Por. S. De Fiores, Mariologia w wymiarze estetycznym [brak inf. o tłum], SM 11 (2009) nr 2, s. 161-192.
} 
i Hull (Quebec, Kanada) wynika, że większość respondentów opowiadała się za nieosobowymi wyobrażeniami Boga. Jest to zjawisko, które na przestrzeni ostatnich dwudziestu lat dokumentują krajowe i międzynarodowe badania porównawcze ${ }^{2}$. Wydaje się, że pewnym sposobem zaradzenia temu negatywnemu procesowi ujmowania Boga nieikonicznie i nieosobowo, który pojawił się we współczesnym chrześcijaństwie doby ponowoczesnej, jest odwołanie się do świata obrazów. Paradoksalnie we współczesnym zsekularyzowanym świecie powiększyły się szanse wizerunków maryjnych na spełnianie funkcji przekazywania sacrum, ze względu na bliskość Maryi w Jej człowieczeństwie. Człowiek każdej epoki, a tym bardziej epoki medialnej, potrzebuje zewnętrznych (materialnych) sposobów na przeżywanie swojego wewnętrznego życia religijnego.

Jakkolwiek ikony stanowią trwałe i nieustannie obecne dziedzictwo Zachodu, to jednak w ostatnim okresie doczekały się rewitalizacji w tym kręgu religijno-kulturowym, choć zawęża się je niestety najczęściej jedynie do wymiaru estetycznego. Pełna teologia świętego obrazu zawiera bowiem w sobie elementy wschodnie i zachodnie ${ }^{3}$. Trzeba pamiętać, że walor artystyczny ikony jest wartością poniekąd uboczną, by nie powiedzieć - marginalną. Święte obrazy zawierają w sobie znacznie więcej. W tradycji Kościoła wschodniego, wyrażonej tekstami soborowymi, ikona jest „sakramentalnym uczestniczeniem istoty Boga", jest miejscem, gdzie Bóg jest obecny. Mówiąc poetycko, to punkt styczności nieba z ziemią. Ikona jest oknem nieba. To teofania, objawienie się Boga człowiekowi. Miał rację Paweł Florenski, kiedy pisał: „Ze względu na słabość wzroku duchowego wiernych Kościołowi, w trosce o modlących się, przychodzi pomagać im w przezwyciężeniu ich opieszałości duchowej: wskazywać owe niebiańskie widzenia, promienne i wyraźne, utwierdzać je materialnie, ślad ich utrwalać farbą"4. Pomoc przychodzi w ikonie, zwłaszcza w świętym obrazie Matki Bożej.

Należy już na wstępie wyeliminować pewien błąd ahistorycyzmu, często pojawiający się przy temacie ikon. Otóż panuje błędne przekonanie, iż ikony są właściwe wyłącznie liturgii Kościołów Wschodu, a czasami łączy się

2 Por. W. Siwak, Maryja w tajemnicy Chrystusa w polskim kulcie maryjnym, dz. cyt., s. $211 n$.

3 Por. B. Kochaniewicz, Wschodnie i zachodnie elementy teologii ikony w pismach Jana Pawła II, [w:] Dziedzictwo chrześcijańskiego Wschodu i Zachodu - między pamięcia a oczekiwaniem, red. J. Grabowski, U. Cierniak, Częstochowa 2006, s. 267-278 (Człowiek, Wiara, Kultura, 2).

${ }_{4}^{4}$ P. Florenski, Ikonostas i inne szkice, przeł. Z. Podgórzec, Białystok 1997, s. 128 (Kościół Wschodni). 
je nawet tylko z rosyjskim kręgiem kulturowym, co jest sporym nadużyciem. Należy pamiętać, że kiedy powstawały i rozpowszechniały się pierwsze ikony, Kościół nie był podzielony. Ruś, która przyjęła nową religię dopiero w 988 roku, była ostatnim państwem, które otrzymało chrzest z Bizancjum Kościół bizantyjski był pierwotnie jedną z diecezji, a jego osiągnięcia w zakresie świętych obrazów stanowiły zaledwie wspaniałą odmianę w ramach już powszechnego nurtu artystycznego. Ikony są więc kulturowym dziedzictwem całego świata chrześcijańskiego. Przed schizmą, która w sposób tragiczny podzieliła Kościół Chrystusa w 1054 roku na wschodni i zachodni, ikony istniały już od co najmniej czterech, a nawet pięciu stuleci w całym chrześcijaństwie, od Syrii po Egipt, od bizantyjskiego Wschodu w Azji po karoliński Zachód Europy 5 .

\subsection{Biblijny zakaz sporządzania obrazu?}

W Starym Testamencie znajduje się wyraźny zakaz sporządzania jakichkolwiek obrazów, rzeźb czy wyobrażeń mających związek z Bogiem. Pierwsze przykazanie Dekalogu, które ujawnia jedyność i nieporównywalność Boga z jakimkolwiek innym stworzeniem, wzywa wprost do oddawania należnej czci jedynie Jemu. Księga Wyjścia poucza: „Nie będziesz miał cudzych bogów obok Mnie! Nie będziesz czynił żadnej rzeźby ani żadnego obrazu tego, co jest na niebie wysoko, ani tego, co jest na ziemi nisko, ani tego, co jest w wodach pod ziemią! Nie będziesz oddawał im pokłonu i nie będziesz im służył, ponieważ Ja Pan, twój Bóg, jestem Bogiem zazdrosnym” (Wj 20, 3-5a). Ten zakaz, wypływający z pierwszego przykazania Dekalogu, jest tą częścią Pięcioksięgu, która jest wspólnym dziedzictwem zarówno tradycji jahwistycznej, jak i chrześcijaństwa. Właśnie na tę biblijną zasadę powoływali się ikonoklaści, którzy pojawili się w vIII i IX wieku w Bizancjum i przeciwstawiali się wszelkiego rodzaju czci obrazów i figur, przedstawiających zwłaszcza Chrystusa.

Jak prawidłowo - z pozycji współczesnych badań egzegetycznych - rozumieć ów zakaz Pisma Świętego odnośnie do sporządzania wizerunków Boga? Naród żydowski egzystował pomiędzy starożytną kulturą Egiptu

5 Por. O. Popova, E. Smirnova, P. Cortesi, Ikony, tłum. T. Łozińska, Warszawa 1998, s. 7; por. Z. Bator, Problem piękna w nowożytnych wizerunkach maryjnych, SM 13 (2011) nr 3-4, S. $255-282$. 
a starożytną kulturą Mezopotamii. Dlatego nieustannie był narażony na wpływy tych kultur, zwłaszcza w dziedzinie religijnej, tym bardziej że kult posągów i obrazów bóstw był dość mocno rozpowszechniony na całym starożytnym Bliskim Wschodzie ${ }^{6}$. Ta uwaga pozwala należycie spojrzeć na wspomniany zakaz, który bardziej dotyczył odcięcia się ludu Izraela od jakichkolwiek religijnych wpływów ościennych. Prorocy i mędrcy Izraela $\mathrm{z}$ zapałem uświadamiali ludowi, że bogowie pogan to ułuda (por. Ps 96, 6). W Psalmie 135, 15-18 czytamy zaś: „Bożki pogańskie to srebro i złoto, dzieło rąk ludzkich. Mają usta, ale nie mówią, mają oczy, ale nie widzą. Mają uszy, ale nie słyszą; i nie ma oddechu w ich ustach. Podobni są do nich ci, którzy je robią, i każdy, co w nich ufność pokłada”. W łonie samej religii izraelskiej nie było potrzeby takiego surowego zakazu. Bóg objawił się swojemu ludowi poprzez swoje słowo, a nie obraz. W odróżnieniu od bóstw egipskich, mezopotamskich i kananejskich Jahwe nie objawił się w obrazach?

Otóż starotestamentalny zakaz tworzenia obrazów i figur należy rozumieć na tle całej ówczesnej kultury przesiąkniętej bałwochwalstwem oraz w kontekście wiary w jednego Boga. Zakaz ten miał na celu odizolowanie narodu izraelskiego od rytuału kultów pogańskich i zabezpieczenie czystości wiary w jedynego Boga. Prawo to było szczególnie ważne wtedy, kiedy $\mathrm{w}$ religii jahwistycznej nie ugruntował się jeszcze dostatecznie monoteizm, ale panowała idolatria. Dlatego po wiekach zmagań, gdy doszło już do jednoznacznego przekonania, iż istnieje tylko jeden Bóg i poza Nim nie ma innego, ten zakaz utracił swój sens. Właściwie stanie się to dość czytelne dopiero w tradycji nowotestamentalnej, gdzie nie będzie już niebezpieczeństwa idolatrii, a chrześcijańskie obrazy wyrażające treści religijne nie będą stanowić zagrożenia dla prawdy wiary o jednym i jedynym Bogu?

Pewnych elementów skulpturystycznych stanowiących godny uwagi wyjątek od zakazu czynienia obrazów można dopatrzyć się zresztą już w Starym Testamencie. Odnosi się on do najświętszego miejsca, za jaki uchodziła przebłagalnia, pokrywa Arki Przymierza (por. Wj 25, 10-22). Przebłagalnia (hebr. kapporeth) była złotą płytą, miejscem, skąd Bóg przemawiał do Mojżesza (por. Kpł 16, 2; Lb 7, 89), i zarazem jakby narzędziem

6 Por. R. Rubinkiewicz, Czy Bóg zakazał czcić obrazy?, [w:] Ikona liturgiczna. Ewangelizacyjne przesłanie ikonografii maryjnej, red. K. Pek, Warszawa 1999, s. 18 (Theotokos, 9).

7 Por. tamże, s. 22.

8 Por. tamże, s. 24. 
odpuszczania grzechów (por. Kpł 16, 13. 15). Jahwe nakazał Mojżeszowi, aby uczynił cheruby, z których jeden miał być umieszczony na jednym końcu przebłagalni, a drugi na drugim. „Cheruby będą miały rozpostarte skrzydła ku górze i zakrywać będą swymi skrzydłami przebłagalnię, twarze zaś będą miały zwrócone jeden ku drugiemu. I ku przebłagalni będą zwrócone twarze cherubów. Umieścisz przebłagalnię na wierzchu arki [...]. Tam będę się spotykał z tobą i sponad przebłagalni i spośród cherubów, które są ponad Arką Świadectwa, będę z tobą rozmawiał o wszystkich nakazach, które dam za twoim pośrednictwem Izraelitom" (Wj 25, 20-22). Mamy zatem do czynienia $\mathrm{z}$ figurami, a przecież obowiązywał zakaz jakichkolwiek materialnych wyobrażeń!

Te pełne tajemniczości istoty, które przykrywały Arkę i jej strzegły, wyrzeźbiono, aby skrywały tajemnicę obecności samego Boga. W Nowym Testamencie przez przebłagalnię będzie rozumiany Jezus Chrystus. Paweł Apostoł nazwie ukrzyżowanego Chrystusa żywym i prawdziwym przebłaganiem za nasze grzechy. To przeniesienie starotestamentalnej treści pojęcia przebłagalni na jej nowotestamentalny odpowiednik staje się tym bardziej czytelne, gdy przywołamy fakt, że w czasach deportacji Żydów (tzw. niewoli babilońskiej) przebłagalnia zaginęła. Można tu zaryzykować stwierdzenie, że to w Chrystusie Bóg ujawnił swoją twarz. Oblicze wcielonego Syna Bożego, Jezusa z Nazaretu, jest ostatecznie obliczem Boskim. W tradycję Kościołów Wschodu mocno wpisana jest ikona zmartwychwstania pańskiego, która wyraźnie nawiązuje do wewnętrznego związku między Arką Przymierza a paschą Chrystusa. Na pierwszym planie tej paschalnej ikony mamy postać chwalebnego Pana stojącego na płycie, którą można odnosić do przykrycia grobu, ale też może być ona wskazaniem na kapporeth Starego Przymierza. Chrystus po prawej i lewej stronie jest otoczony cherubami. Ten podstawowy obraz Starego Testamentu zostaje zachowany, jakkolwiek jest on już w nowy sposób ukształtowany przez zmartwychwstanie ${ }^{9}$.

Należy zauważyć, że zakaz tworzenia obrazów obowiązujący w islamie i judaizmie poddano radykalnej zmianie interpretacyjnej, i to w znacznym stopniu, w okresie od III i IV wieku po Chrystusie. Jako ornament sanktuariów - synagog zostały dopuszczone niefigurowe geometryczne wyobrażenia. Judaizm czasów Jezusa i aż do trzeciego stulecia wspaniałomyślnie

9 Por. J. Ratzinger, Der Geist der Liturgie. Eine Einführung, Freiburg-Basel-Wien 2000, s. 99 (na ogół cytowana jest polska wersja tej książki, która pod tytułem Duch liturgii w tłum. E. Pieciul ukazała się w Poznaniu w 2002). 
rozwinął interpretację kwestii obrazów. Potwierdzają to dzisiejsze badania archeologiczne, które w starych synagogach odsłaniają bogato zdobione materialne przedstawienia scen biblijnych. W żadnym wypadku nie uchodziły one tylko za obrazy minionych wydarzeń, ale były rodzajem obrazowego pouczenia, opowiadań ( haggada), które przypominając, tworzyły teraźniejszość. W liturgicznych świętach minione czyny Boga są teraźniejszością ${ }^{10}$.

Widać zatem, że w tradycji judeo-chrześcijańskiej cześć świętych obrazów nie tylko po części istniała, ale była też ona czymś właściwym i poprawnym teologicznie. Oczywiście w religii jahwistycznej zakaz sporządzania obrazów kultowych miał swoje istotne racje, znajdujące uzasadnienie $\mathrm{w}$ niebezpieczeństwie popadnięcia w idolatrię, ale chodziło chyba nie tyle o niewytwarzanie wizerunków Jahwe, ile przede wszystkim o niesporządzanie podobizn żadnych bożków. Księga Wyjścia pozwala raczej wyprowadzić właśnie taką interpretację, ucząc: „Nie będziesz czynił żadnej rzeźby ani żadnego obrazu tego, co jest na niebie wysoko, ani tego, co jest na ziemi nisko, ani tego, co jest w wodach pod ziemią!" (Wj 20, 3-4). Natomiast zasadnicza zmiana weszła wraz z chrześcijańską teologią, gdy tworzenie obrazów stało się potwierdzaniem tajemnicy wcielenia, a one same materialnymi nośnikami duchowych dóbr zbawczych, wysłużonych przez Jezusa Chrystusa w tajemnicy Jego śmierci i zmartwychwstania ${ }^{11}$.

\subsection{Z historii teologii świętego obrazu}

Historia kształtowania się teologii ma swoją burzliwą przeszłość. Pierwsza teologiczna podstawa ikony, jaką jest chrześcijańska prawda wiary we wcielenie, domagała się w Kościele starożytnym szerszego rozpracowania. Człowiek stworzony przez Boga na Jego obraz i podobieństwo (por. Rdz 1, 27) stał się żywą ikoną Boga, wprawdzie zniekształconą przez grzech pierworodny, lecz odnowioną przez wcielenie Syna Bożego.

Ikona łączy w sobie tradycje tysiącletniej kultury i głębokiej religijności cywilizacji przedchrześcijańskich. Artyści chrześcijańscy Kościoła pierwotnego przyswoili sobie wzory, techniki, symbole i materiały od stuleci stosowane w malarstwie ściennym, w mozaikowej dekoracji posadzek czy w portretach grobowych. W chrześcijańskiej ikonie wyraźne widoczne jest

\footnotetext{
${ }^{10}$ Por. tamże, s. 100.

${ }^{11}$ Por. T. D. Łukaszuk, Wcielenie fundamentem ikony, [w:] Ikona liturgiczna, dz. cyt., s. 25-39.
} 
dziedzictwo tradycji malarstwa epoki późnego antyku, zwłaszcza portretu rzymskiego, inspirującego się wzorami hellenistycznymi ${ }^{12}$. Ponieważ daleko posunięty symbolizm sztuki wczesnochrześcijańskiej uznano za niewystarczającą pomoc dla liturgii, Synod Trullański w 692 roku, wychodząc od prawdy o wcieleniu, uznał za możliwe i celowe przedstawianie Osób Boskich za pomocą środków materialnych (np. Chrystusa zaczęto przedstawiać w ujęciu portretowym, a nie jak dotychczas symbolicznym, np. pod postacią Baranka).

Bardzo dynamicznie rozwijająca się pobożność ikoniczna wzbudzała u wielu zastrzeżenia. Obawa, że wyznawcy młodej religii chrześcijańskiej nie do końca są jeszcze utwierdzeni w swojej wierze, wywołała u ojców Kościoła nieufność wobec obrazów, a nawet głosy upomnienia, aby powstrzymano się od ich wykonywania. Jednakże samo chrześcijaństwo, które edyktem mediolańskim cesarza Konstantyna z 313 roku zyskało wolność, a za cesarza Teodozjusza edyktem tesalońskim z 380 roku oraz serią dekretów antypogańskich podniesione zostało prawie do rangi religii państwowej, rozszerzało się szybko i stało się religią powszechną. Teodozjusz nakazał wszystkim wiernym wyznawać „religię, której niegdyś Apostoł Piotr nauczał Rzymian i której teraz trzyma się papież Damazy”. Dotąd przyjęcie chrześcijaństwa nie dawało żadnej korzyści materialnej ani też nie wiązało się z podniesieniem społecznej pozycji. Teraz było odwrotnie. Jego przyjęcie otwierało dostęp do urzędów i kariery. Wprawdzie spowodowało to, że liczebność chrześcijan wzrosła ogromnie - w IV wieku przystąpiło do Kościoła kilka razy więcej ludzi niż przez dwieście pięćdziesiąt poprzednich lat- jednak nie było to równoznaczne ze wzrostem wewnętrznym Kościoła. Więcej nawet: ogólny poziom życia duchowego tych olbrzymich rzesz - ochrzczonych, ale nieschrystianizowanych - był dość niski. Mimo to dokonująca się konsekwentnie, choć powoli, ewangelizacja myślenia i zachowania, obyczajów, budownictwa i symboliki pogańskiej wprowadzała chrześcijańską sakralność ${ }^{13}$. Jej przejawem stał się właśnie święty obraz, który znalazł szeroką akceptację, szczególnie w pobożności ludowej i monastycyzmie.

Misyjność chrześcijaństwa, jego pneumatyczny dynamizm prowadzący do wychodzenia ze świata semickiego (ale nie do zrywania z nim), będącego przecież kulturą słowa, i wnikania w świat myślenia greckiego, będącego

12 Por. tamże, s. 18.

${ }^{13}$ Por. D. Olszewski, Dzieje chrześcijaństwa w zarysie, Kraków 1996, s. 48 oraz 56-57. 
kulturą znaku, prowadziły i w sposób naturalny skłaniały do używania materialnych znaków i symboli. Oczywiście dokonywała się zamiana ich treści pogańskich na treści objawienia judaistyczno-chrześcijańskiego. Ponadto sama liturgia, która rozwijała się coraz szerzej i przyjmowała rozbudowane formy, domagała się większej liczby znaków. Rozwój sztuki kościelnej prowadził od prostych znaków informujących poprzez symbole, pełne treści i mocy, do świętego obrazu, czyli ikony we właściwym sensie. Naturalnie ów proces kształtowania się pobożności związanej z kultem świętych obrazów nie przebiegał bez napięć, tym bardziej że praktyka wyprzedzała tu znacznie myśl teologiczną. W IV wieku, zwanym „złotym okresem patrystyki", podniosły się głosy krytyczne zarówno pod adresem form kultu obrazów, jak i samej sztuki ikonograficznej. Z kolei za pontyfikatu Grzegorza Wielkiego (590-604) postrzegano cześć oddawaną świętym jako jeden z ważnych środków duszpasterskiego działania, a obrazy święte miały uzupełniać słowa nauczania kaznodziejskiego. Ponadto na Wschodzie lud i duchowieństwo, zrażeni do słowa mówionego wskutek długotrwałych i różnorakich sporów teologicznych, często nazbyt teoretycznych i abstrakcyjnych, szukali konkretnych znaków religijnych, jakimi były z pewnością obrazy. W vi wieku kult obrazów jeszcze bardziej się rozpowszechnia, przy czym lud nie traktuje ich jedynie jako „Biblii ubogich”, ale jako źródło łask Bożych i błogosławieństw. Ta sytuacja zrodziła potrzebę teologicznej refleksji, którą podjął właśnie wspomniany już Synod Trullański ${ }^{14}$.

Trzy kanony Synodu Trullańskiego pozostają w ścisłym związku z ikonografią. Kanon 73 dotyczy znaku krzyża; wylicza racje, dla których powinniśmy krzyżowi okazywać należną cześć. Interesujący jest także kanon 82, uczący o treści świętego obrazu. Synod z 692 roku zaleca, aby zamiast Baranka - jak to było dawniej - na obrazach był „malowany w ludzkim kształcie wizerunek Tego, który gładzi grzechy świata, Chrystusa, naszego Boga. Dzięki temu - ogarniając myślą dostojność uniżenia Boga Słowa - będziemy również doprowadzeni do uświadomienia sobie Jego zamieszkania w ciele [wśród nas], Jego męki i zbawczej śmierci oraz dopełnionego przez to odkupienia świata" ${ }^{\prime 1}$. W kanonie tym po raz pierwszy oficjalne nauczanie Kościoła wskazuje na związek, jaki istnieje między ikoną a dogmatem wcielenia, ukonkretniony w cielesnej rzeczywistości Chrystusa Pana. Z kolei

${ }^{14}$ Por. T. D. Łukaszuk, Obraz święty - ikona w życiu, w wierze i $w$ teologii Kościoła, Częstochowa 1993, s. 31-39.

15 Tamże, s. 40. 
kanon 100 poświęcono zagadnieniu obrazów i ich prezentacji w miejscach publicznych. Ojcowie synodalni przestrzegają przed niewłaściwymi obrazami świeckimi lub pogańskimi, zawierającymi dwuznaczne treści moralne, i zakazują ich wystawiania.

Ponieważ w Synodzie sub Trullo uczestniczyli wyłącznie biskupi ze Wschodu, jego ikonograficzne kanony nie objęły całego Kościoła. Negatywna postawa Rzymu miała w przyszłości niekorzystnie zaciążyć na sztuce sakralnej Zachodu. Kościół rzymski nie uczestniczył pozytywnie w procesie tworzenia nowego języka malarskiego, zdolnego do wypowiedzenia głębokich treści duchowych. Przewodnia rola przypadła tu Kościołowi konstantynopolitańskiemu, a później jego spadkobiercom - autokefalicznym Kościołom prawosławnym ${ }^{16}$.

Mimo tych znaczących rozstrzygnięć doktrynalnych, wypowiedzianych w wiążący sposób, niecałe czterdzieści lat po synodzie trullańskim doszło do potężnego ruchu radykalnie zwalczającego obrazy. Ikonoklazm, zwany inaczej obrazoburstwem, wybuchł niespodziewanie. $Z$ jednej strony ikonoklazm wynikał z motywów autentycznie religijnych, z niezaprzeczalnego zagrożenia przesadnego uwielbienia obrazu, a $\mathrm{z}$ drugiej - $\mathrm{z}$ aktualnej sytuacji politycznej. Cesarzom Bizancjum zależało, aby niepotrzebnie nie prowokować muzułmanów i żydów. Zwalczanie obrazów - według ich przekonania - mogło przyczynić się do wzmocnienia jedności cesarstwa i poprawy stosunków z jego muzułmańskimi sąsiadami. Inicjatorem ikonoklazmu był cesarz Leon III (717-741), zamierzający zreformować życie religijne. Chcąc oczyścić Kościół z resztek idolatrii, kryjącej się według niego w obrazach i ich kulcie, wydał w 726 roku edykt zakazujący sporządzania wizerunków Chrystusa. Jedynie znak krzyża (bez Ukrzyżowanego) mógł być „Jego pieczęcią”. Tym samym pojawiła się alternatywa: albo krzyż, albo obraz.

Mimo odrzucenia cesarskich rozporządzeń przez ówczesnego papieża Grzegorza II (660-731) i patriarchę Konstantynopola Germana rozszalała się burza prześladowań wobec wszystkich czcicieli obrazów, a zwłaszcza wobec mnichów i prostego ludu. Doszło do bezpardonowego fizycznego niszczenia, włącznie z paleniem, setek tysięcy świętych wizerunków. Późniejsze etapy walki były nawet znaczone krwią męczenników i cierpieniami wyznawców. Liczni biskupi zostali skazani na wygnanie, zaś inni obrońcy obrazów - tak duchowni, jak i świeccy - znosili różnorakie udręki, czasami

\footnotetext{
${ }^{16}$ Por. tamże, s. 44.
} 
aż do męczeństwa. Znaczącą rolę odegrał św. German, który potrafił opierać się naciskom imperatora-ikonoklasty Leona III Izauryjczyka ${ }^{17}$.

W tych trudnych i skomplikowanych warunkach zmagań o właściwe podejście do świętych obrazów i związanego z nimi kultu pogłębiała się i krystalizowała chrześcijańska teologia ikony. W okresie obrazoburstwa nastąpiło określenie istoty ikony, będące odpowiedzią na najważniejsze pytanie: czy kult dotyczy materiałów, z których wykonana jest ikona, czy też wykracza poza przedmiot i wskazuje na rzeczywistość transcendentną? Wśród ikonodulów, którzy wypracowywali właściwą teologię ikony, był Jan z Damaszku (650-749), teolog i poeta. Ten ojciec Kościoła swoje poglądy na temat obrazów zawarł w trzech mowach przeciwko ikonoklastom. Jego myśli zostały następnie rozwinięte przez Nicefora I oraz Teodora Studytę. W początkowej fazie obrazoburstwa obrońcy obrazów stanowili ruch żywiołowy i ludowy, jednak w toku walk nabrał on charakteru bardziej intelektualnego i stworzył teologiczno-doktrynalną podbudowę dla praktyk religijnych. W tym kontekście doszło do zwołania II Soboru Nicejskiego (w 787 roku) przez cesarzową Irenę. Głównym jego postanowieniem było sformułowanie dogmatu o czci oddawanej ikonom oraz przywrócenie kultu obrazów. Znalazło to swój wyraz już w trakcie piątej sesji Soboru, gdy na honorowym miejscu obok księgi Ewangelii położono ikonę Chrystusa ${ }^{18}$.

Ikonoklazm został zdecydowanie odrzucony jako suma wszystkich herezji, ponieważ niósł ze sobą duże niebezpieczeństwo, zwłaszcza w stosunku do podstawowych prawd chrystologicznych. Ikona, wychodząc $z$ faktu wcielenia, to wcielenie potwierdza i umacnia w świadomości wiary chrześcijan.

${ }_{17}$ Por. J. Ratzinger, Duch liturgii, dz. cyt., s. 109; I. Mroczkowski, Ikonolatria, [w:] EK, t. 7, Lublin 1997, k. 14-15. Dla uchwycenia całości ruchu ikonoklastycznego należy przywołać jego główne przyczyny. Ze strony ikonodulów pojawiły się liczne nadużycia, przejawiające się w niezrozumieniu właściwego sensu wizerunków, względnie w zniekształceniu oddawanego im kultu. Niektórzy chrześcijanie, zdobiąc kościoły i domy w swojej naiwnej gorliwości, sądzili, iż to już zapewni im zbawienie. W przeważającym ogólnym nurcie właściwej pobożności ikon niektóre jej formy graniczyły z profanacją. Z licznych deformacji przykładowo można wymienić praktykę przybierania obrazów za rodziców chrzestnych przy sakramencie chrztu lub za świadków przy obłóczynach zakonnych. Kapłani zdrapywali cząsteczki farby z obrazów i mieszali je z konsekrowanym winem, podając wiernym jako Komunię Świętą. Inni kapłani dokonywali konsekracji eucharystycznej nie na ołtarzu, ale na obrazie, bo to miało gwarantować skuteczność przemiany. Dochodziło wreszcie i do czystej ikonolatrii, gdy nie czczono świętej osoby przedstawionej na malowidle, ale samo już malowidło. Szerzej na ten temat pisze T. D. Łukaszuk, Obraz święty - ikona w życiu, w wierze i w teologii Kościoła, dz. cyt., s. 46nn.

${ }^{18}$ Por. A. Frejlich, Ikona, [w:] EK, t. 7, Lublin 1997, k. 9. 
Wcielenie oznacza bowiem przede wszystkim, że niewidzialny Bóg wkroczył w przestrzeń widzialnego, abyśmy my, ludzie - przywiązani do materialności i w nią uwikłani - mogli Go rozpoznać. W tym sensie można mówić o nieustannym dokonywaniu się wcielenia w historycznym, zbawczym działaniu Boga i Jego objawianiu się. To zstępowanie Boga ma na celu włączenie nas w proces wstępowania. Powraca tu znowu pytanie: dlaczego Bóg stał się człowiekiem? Celem wcielenia jest przemiana przez krzyż oraz nowa cielesność zmartwychwstania. Bóg szuka nas tam, gdzie jesteśmy. Jednak nie chce, abyśmy tam pozostali, lecz abyśmy się wznieśli ponad siebie samych ${ }^{19}$.

Odrzucenie ikony było zatem zakwestionowaniem samej istoty chrześcijańskiej specyfiki religijnej, jej odmienności wobec judaizmu czy nowo powstałego islamu, związanego z prorokiem Mahometem (570-632). Ikonoklazm godził tym samym w orzeczenia chrystologiczne Soboru Chalcedońskiego (w 451 roku), mówiące o zjednoczeniu w Boskiej Osobie Jezusa Chrystusa dwóch natur - Boskiej i ludzkiej. II Sobór Nicejski, trwający zaledwie dwa miesiące, odróżnił kult należny samemu Bogu (latreia) od czci świętych i wizerunków (proskynesis) oraz podał definicję o prawowierności obrazów. Ojcowie soborowi orzekli, że:

przedmiotem kultu nie tylko powinny być wizerunki drogocennego i ożywiającego krzyża, ale tak samo czcigodne i święte obrazy malowane, ułożone w mozaikę lub innym sposobem wykonane, które ze czcią umieszcza się w kościołach, na sprzęcie liturgicznym czy na szatach, na ścianach czy na desce, w domach czy przy drogach z wyobrażeniami Pana naszego Jezusa Chrystusa, Boga i Zbawcy, świętej Bogarodzicy, godnych czci Aniołów oraz wszystkich świętych i świątobliwych mężów. Im częściej bowiem [wierni] spoglądają na ich obrazowe przedstawienie, tym bardziej także się zachęcają do wspominania i umiłowania pierwowzorów, do oddawania im czci i pokłonu - chociaż nie adoracji, która według wiary należy się wyłącznie Bożej naturze. W ten sposób oddaje się hołd przez ofiarowanie kadzidła i zapalanie świateł przed wizerunkami drogocennego i ożywiającego krzyża, świętych Ewangelii i innych świętych obrazów, jak to było w pobożnym zwyczaju u przodków. „Kult bowiem obrazu skierowany jest do wzoru" (św. Bazyli, O Duchu Świętym 18, 45); a kto składa hołd obrazowi, ten go składa Istocie, którą obraz przedstawia ${ }^{20}$.

\footnotetext{
19 Por. J. Ratzinger, Duch liturgii, dz. cyt., s. 111-112.

${ }^{20}$ DS 600 (BF VII 637).
} 
Po okresie ikonoklazmu, który w 843 roku zakończył się „,zwycięstwem świętych obrazów" (tzw. święto Triumfu Ortodoksji), ikony jeszcze bardziej rozpowszechniły się w świecie chrześcijańskim. Nie tylko czczono je w świątyniach, lecz także przechowywano na honorowych miejscach w domach, niesiono jako sztandar (labarum) na czele wojsk, obnoszono w procesjach przez ulice miast i wsi, po polach, aby zażegnać ewentualne klęski lub wybłagać potrzebne łaski oraz obfite zbiory. Obecność ikon pojmowano jako dobroczynną i opiekuńczą. Święty obraz uczestniczył w każdym momencie życia ludzkiego: był obecny przy narodzinach, przy sakramentach chrztu, małżeństwa, towarzyszył pielgrzymom, chorym niósł ulgę w cierpieniu, czuwał przy konających, a także był wkładany wraz ze zmarłym do trumny ${ }^{21}$.

Podążając dalej śladem dziejów ikony, możemy zauważyć, że w sztuce starożytnego chrześcijaństwa i aż po kres sztuki romańskiej, czyli do początku XıII wieku, w kwestii obrazów nie istniała istotna różnica między Wschodem i Zachodem. Zachód podkreślał z pewną wyłącznością dydaktyczno-pedagogiczną funkcję obrazów (św. Augustyn, św. Grzegorz Wielki). Zarówno Księgi karolińskie (Libri Carolini), jak i synody we Frankfurcie (w 794 roku) i w Paryżu (w 824 roku) występowały przeciwko błędnym interpretacjom viI Soboru Powszechnego. Tematyka i zasadniczy kierunek sztuki obrazu pozostawały takie same, chociaż w sztuce romańskiej zaczęła dominować rzeźba, która nie przyjęła się w Kościele wschodnim. Znacząca odrębność pojawiła się w gotyku. Rosyjski teolog prawosławny Paul Evdokimov (1901-1970) uważa, że na Zachodzie pewną rolę odegrało dokonujące się w XIII wieku przejście od platonizmu do arystotelizmu. W jego wyniku sztuki plastyczne próbowały przedstawiać przede wszystkim to, co się wydarzyło, a historia zbawienia zaczęła być traktowana nie tyle jako sakrament, ile ciąg zdarzeń, które dokonały się w czasie. Liturgia zwróciła się zaś bardziej w stronę tajemnic życia Jezusa. Wymownym tego przejawem stała się wspaniała sztuka gotyckich witraży, ukazujących całą historię Boga i ludzi od stworzenia po paruzję ${ }^{22}$.

Renesans przyniósł ze sobą emancypację człowieka. Zaakcentował piękno i wezwał do kontemplacji estetyzmu, ale nie odniósł tego do świata transcendencji. Zaskoczony wielkością człowieka zamknął się w tragicznym

${ }^{21}$ Por. O. Popova, E. Smirnova, P. Cortesi, Ikony, dz. cyt., s. 10.

${ }^{22}$ Por. J. Ratzinger, Duch liturgii, dz. cyt., s. 113-116. 
wymiarze antyku. Wprawdzie tworzone dzieła były sztuką religijną, ale nie była to sztuka sakralna we właściwym znaczeniu ${ }^{23}$.

$\mathrm{Z}$ kolei sztuka baroku, mocno związana z reformą Kościoła rozpoczętą wraz ze Soborem Trydenckim (1545-1563), ma różne aspekty i sposoby realizacji. Trzymając się tradycji zachodniej, Sobór podkreślił dydaktyczno-pedagogiczny charakter sztuki. Próbował też zaakcentować transcendentalne wymiary liturgii. Późniejsze oświecenie zamknęło wiarę w swoistym intelektualnym getcie. Dokonało się smutne rozejście kultury i wiary, które właściwie pokutuje do dzisiaj. Sobór Watykański iı (1962-1965) podjął trud przepracowania tego tragicznego dziedzictwa. Jednakże sytuacja jest nazbyt skomplikowana. Przeżywamy obecnie poważny kryzys nie tylko sztuki sakralnej, lecz także sztuki w ogóle, i to w wymiarze wcześniej nieznanym ${ }^{24}$.

Jakkolwiek teologiczna refleksja nad ikoną nie ustała wraz ze sporami ikonoklastycznymi i orzeczeniami doktrynalnymi is Soboru Nicejskiego, to jednak - wskutek rozbicia chrześcijaństwa w XI wieku oraz drastycznego zmniejszenia się wpływów bizantyjskiego Kościoła Wschodu - znaczenie świętego obrazu w chrześcijańskiej pobożności wyraźnie spadło. Przyczyn takiej sytuacji jest na pewno wiele i nawet trudno byłoby je wszystkie przywołać z imienia. Złożyły się na to nie tylko dominacja Kościoła zachodniego i jego specyficzna droga historycznego rozwoju w aspekcie instytucjonalnym, lecz także nade wszystko kontekst społeczno-polityczny. Ten stan rzeczy jest dodatkowo wzmacniany przez nieustanną niechęć i sceptycyzm $\mathrm{z}$ jego strony wobec ikony, co widać choćby w jedynie połowicznym wypełnianiu ustaleń Soboru z 787 roku do dzisiaj. Zachód wciąż odmiennie traktuje ikonę, zwłaszcza maryjną, będącą przecież absolutnie wspólnym dziedzictwem wszystkich chrześcijan. Wynika to nie tylko z różnicy kultur i odmiennych tradycji, lecz także i z podejścia do kanonu pisania ikon. Dość wspomnieć, że ikonopisanie w świadomości wschodniej stanowiło swego rodzaju akt sakralny, obwarowany szczególnymi rygorami, tak w zakresie formy, jak i wzorów ikonograficznych. Z kolei twórcy zachodni od przełomu wieków XIII i XIV zaczęli odbierać kanon jako ograniczenie swej wolności artystycznej i autoekspresji ${ }^{25}$.

\footnotetext{
${ }^{23}$ Por. tamże, s. 117

${ }^{24}$ Por. tamże, s. 118.

${ }^{25}$ Por. Z. Bator, Macierzyństwo duchowe Maryi w chrześcijańskiej ikonografii na podstawie wybranych przykładów, sM 13 (2011) nr 3-4, s. 130-155.
} 


\subsection{Wcielenie: chrystologiczny fundament maryjnej ikony}

Chrześcijańska ekonomia zbawienia, która swój początek bierze z tajemnicy wejścia Syna Bożego w historię człowieka i świata, koncentruje się wokół misterium wcielenia, kiedy to Maryja wypowiada swoją zgodę wobec Jahwe. Inkarnacja rozpoczęła nowy etap łączenia człowieka z Bogiem, tego, co ludzkie, z boskim. Bezsprzecznie uwidoczniło się to $\mathrm{w}$ sposób najpełniejszy i niepowtarzalny w odwiecznym Synu Bożym, który stał się Człowiekiem dzięki Maryi z Nazaretu. To On, Jezus Chrystus, połączył w sobie wieczność z czasem, niebo z ziemią, ducha z materią. Dlatego też jest przez swoje doskonałe człowieczeństwo najdoskonalszą ikoną Bóstwa, a $\mathrm{z}$ tajemnicy wcielenia dają się wyprowadzić najgłębsze i wystarczające podstawy całej refleksji teologicznej ikony.

Główne przesłanie wypływające z kontemplacji świętego obrazu nie tyle chce zaakcentować wymiar soteriologiczny osoby i dzieła naszego Odkupiciela, ile podkreślić chrystologiczność każdej ikony. Albowiem wszystkie obrazy tego typu, opierając się na tajemnicy wcielenia, są ikonami Chrystusa. Chodzi tu zarówno o te, które przedstawiają Jego przenajświętsze oblicze, jak i o te, które nawiązują do najważniejszych momentów Jego ziemskiego życia (tzw. „ikony świąteczne”), a także o przedstawiające Jego Boską Matkę, Theotokos, w której dziewiczym łonie dokonało się wcielenie, „Słowo ciałem się stało i zamieszkało między nami”, jak i o wszystkie ikony świętych i błogosławionych. Kanon ikonograficzny nakazuje, aby Maryja nigdy nie była przedstawiana inaczej, jak tylko z Synem lub w kompozycjach z Nim związanych: ikona Matki Bożej w istocie tłumaczy tajemnicę wcielenia. Ponadto ikonami Chrystusa są również te ukazujące postacie świętych Pańskich, którzy - wzorując się na Chrystusie - tak przeszli przez ziemskie życie, że stali się Jego „odbiciem”, Jego obrazem (eikon). Oczywiście samego aspektu soteriologicznego nie chcemy przez to pomniejszać, gdyż łaska, jaką niesie ze sobą święty obraz, staje się przecież naszym wybawieniem tak z zewnętrznej sytuacji ucisku, jak i z naszego wewnętrznego zniewolenia. Ikona uobecnia Chrystusa Zbawcę (soter).

Jak wszystkie ikony są ikonami Chrystusa, tak też każda z nich jest ikoną człowieka. Oprócz wymiaru chrystologicznego zawarty jest w niej bowiem wymiar antropologiczny. W tym właśnie miejscu, gdzie Bóstwo spotyka się z człowieczeństwem, dotykamy naszego wybawienia. Dotykamy samego Jezusa Chrystusa, który nie jest tylko Bogiem ani tylko człowiekiem, 
ale jest i Bogiem, i Człowiekiem; jest wcielonym Bogiem; Bogiem, który przyjął naszą ludzką naturę. W głębokiej i nierozdzielnej jedności tych dwóch przeciwieństw (Słowa i ciała) zawiera się tożsamość Chrystusa, zgodnie z klasyczną formułą Iv Soboru Powszechnego, Soboru Chalcedońskiego z 451 roku: jedna Osoba w dwóch naturach. Jedną Osobą jest Osoba odwiecznego Słowa, Syna Ojca. Dwie natury zaś, w żaden sposób nie zmieszane, ale absolutnie nierozdzielne, to natura Boska i ludzka ${ }^{26}$. W świętym obrazie znajdujemy połączone człowieczeństwo i Bóstwo w Jezusie Chrystusie, będącym Odkupicielem. Ale dlaczego Bóg stał się człowiekiem? Święty Anzelm z Canterbury, wielki teolog średniowiecza, na to pytanie dał przemyślaną i wyczerpującą odpowiedź, pisząc swoje dzieło Cur Deus homo? (Dlaczego Bóg stał się człowiekiem?). Przed tym pytaniem stają także wszyscy, którzy pragną głębiej wniknąć w tajemnicę wcielenia. Najprostszą, ale jakże trafną odpowiedź podaje autor czwartej Ewangelii, gdy pisze: „A Słowo stało się ciałem i zamieszkało wśród nas” $(J 1,14)$. Bóg stał się człowiekiem, aby zrealizować i pokazać prawdziwego i pełnego człowieka, człowieka według zamysłów i planów Bożych ${ }^{27}$.

Tajemnica wcielenia winna być zatem postrzegana jako moment dopełnienia stworzenia. Ta dramatyczna przygoda Boga z człowiekiem, pełna miłości, swoją kulminację znajdzie w zmartwychwstaniu, które jest aktem nowego i ostatecznego stworzenia. Odkupienie nie oznacza bowiem powrotu do stanu rajskiego, do stanu, jaki istniał przed pierwszym ludzkim wiarołomstwem. Początek stworzenia nic nie mówi o jego końcu, ponieważ koniec dzieła stworzenia (misterium paschalne) przewyższa początek. Początek stworzenia nie pozwala się zrozumieć bez odwołania się do jego ukoronowania. Odkupienie, w które była zaangażowana Maryja, jest

${ }^{26}$ DS 301-302 (BF VI 8): „Idąc za świętymi Ojcami, wszyscy jednogłośnie uczymy wyznawać, że jest jeden i ten sam Syn, Pan nasz Jezus Chrystus, doskonały w Bóstwie i doskonały w człowieczeństwie, prawdziwy Bóg i prawdziwy człowiek, złożony z rozumnej duszy i ciała, współistotny Ojcu co do Bóstwa, współistotny nam co do człowieczeństwa, «we wszystkim nam podobny oprócz grzechu» [Hebr. 4, 15]. Przed wiekami z Ojca zrodzony jako Bóg, w ostatnich zaś czasach dla nas i dla naszego zbawienia narodził się jako człowiek z Maryi Dziewicy, Bożej Rodzicielki; jeden i ten sam Chrystus Pan, Syn Jednorodzony ma być uznany w dwóch naturach bez pomieszania, bez zamiany, bez podziału i bez rozłączenia. Nigdy nie została usunięta różnica natur przez ich zjednoczenie, lecz właściwości każdej z nich są zachowane i zjednoczone w jednej osobie, w jednym współistnieniu. Nie można Go dzielić na dwie osoby, ani ich w Nim rozróżniać, ponieważ jest jeden i ten sam Syn jednorodzony, Słowo Boże, Pan Jezus Chrystus".

${ }^{27}$ Por. J. Kudasiewicz, H. Witczyk, Kontemplacja Chrystusa - Ikony miłosiernego Ojca. Medytacje biblijno-kerygmatyczne, Kielce 2002, s. 23-25 (Biblioteka Współczesnej Ambony, 3). 
przekroczeniem pierwszego aktu stwórczego. Dlatego to w misterium wcielenia rozpoczyna się uczłowieczenie Boga (Jezus Chrystus), aby dokonało się przebóstwienie człowi eka (Maryja). Właśnie ikona, która tak mocno swoje fizyczne istnienie i teologiczne uzasadnienie znajduje w prawdzie o wcieleniu, pozwala wierzącemu wniknąć w jego własną tajemnicę zbawienia - i uczynić to razem z Maryją. Wcielenie uczy nas wielkiej i aktualnej prawdy: im bliżej Boga, im ściślejsze zjednoczenie z Bogiem, tym piękniejszy, pełniejszy i prawdziwszy jest człowiek. Jezus Chrystus był najściślej zjednoczony z Bogiem, dlatego był równocześnie najpiękniejszym z ludzi. Maryja prowadzi nas właśnie do Chrystusa, do Bożej pełni. Kontemplując ikonę, człowiek zaczyna pojmować Chrystusa, Maryję i samego siebie. Bez Chrystusa nie może zrozumieć ani kim jest, ani jaka jest jego właściwa godność, ani jakie jest jego pełne powołanie i ostateczne przeznaczenie.

Święty Jan Paweł II w programie na trzecie tysiąclecie chrześcijańskiej wiary, który zawarł w liście apostolskim Novo millennio ineunte, nauczał:

Jezus jest „nowym człowiekiem” (por. Ef 4, 24; Kol 3, 10), który wzywa odkupioną ludzkość do udziału w Jego boskim życiu. W tajemnicy Wcielenia położone zostały podwaliny antropologii, która zdolna jest przekroczyć własne ograniczenia i sprzeczności, zmierzając ku samemu Bogu, a nawet więcej ku „przebóstwieniu” poprzez wszczepienie w Chrystusa człowieka odkupionego, dopuszczonego do udziału w życiu trynitarnym. Ojcowie Kościoła kładli wielki nacisk na ten soteriologiczny wymiar tajemnicy Wcielenia: tylko dlatego, że Syn Boży stał się naprawdę człowiekiem, człowiek może - w Nim i przez Niego - stać się naprawdę dzieckiem Bożym ${ }^{28}$.

Z tego wynika, że cześć oddawana świętemu obrazowi nie jest skierowana nigdy ku niemu samemu, czyli ku wyobrażonemu na nim wizerunkowi, lecz za pośrednictwem wizerunku zwraca się ku temu, kto został przedstawiony, ponieważ w swej istocie obraz stanowi zawsze rzeczywistość względną. Ikona nie jest portretem Osoby Boskiej ani też ilustracją Pisma Świętego, lecz stanowi integralną część liturgii. Dzięki ikonie i przez nią wierny przeżywa swoją osobistą relację z Bogiem w Jezusie Chrystusie, doświadcza Jego żywej obecności. Może wraz z Matką Jezusa zgłębiać tę obecność. Święty Teodor Studyta uczy, że Słowo Boże, wcielając się, przyjęło postać człowieka, Jezusa

${ }^{28}$ Jan Paweł II, List apostolski Novo millennio ineunte do biskupów, duchowieństwa i wiernych na zakończenie Wielkiego Jubileuszu Roku 2000 [dalej: NMI], 23. 
z Nazaretu, o niepowtarzalnych rysach twarzy, które zachowuje wizerunek, upodobniając się do nich, podobnie jak wosk zachowuje odcisk znaku pieczęci. Są to rysy ludzkiego oblicza Boga, które ikona prezentuje w sposób symboliczny, a nie realistyczny, jak portret. W ikonie przedstawiającej Chrystusa, w akcie naszej kontemplacji, doświadczamy obecności Boskiej (teofanii), czyli ostatecznie doznajemy przebóstwienia ${ }^{29}$.

Myśl teologiczna o świętych obrazach, mimo wielu trudności - jakkolwiek wolno, to jednak ostatnio systematycznie - toruje sobie należną drogę. Rozwinęła się ona szczególnie w Rosji w XIX wieku i w początkach wieku XX. Nie można tu pominąć wkładu Pawła Florenskiego, Leonida Uspieńskiego z jego teologią ikony w chrystologicznym ujęciu, Paula Evdokimova z koncepcją pneumatologiczno-sakralną czy Siergieja Bułgakowa ze spojrzeniem sofiologicznym. Także i we Europie ikona jest aktualnie na nowo odkrywana. Temat ikony z pozycji chrystologicznej podjął Christoph Schönborn, z perspektywy mariologii symboliczno-narracyjnej Bruno Forte ${ }^{30}$, a w Polsce w kontekście posoborowym Jerzy Nowosielski, Henryk Paprocki, Tadeusz D. Łukaszuk, Karol Klauza.

Zresztą należy tu dodać, że nigdy cześć wobec świętego obrazu w tradycji łacińskiej nie zanikła całkowicie. Wystarczy się odwołać do ustaleń Soboru Trydenckiego, który dekretem z 1563 roku wzywał do oddawania czci wyobrażeniom Chrystusa, Matki Bożej, aniołów i świętych. Zalecał przy tym biskupom, aby poprzez obrazy czy wyobrażenia wyrażające historię naszego zbawienia wychowywali i umacniali Lud Boży w prawdach wiary, a wszyscy niestrudzenie je czcili. Wówczas wyniknie wielka korzyść ze świętych obrazów $^{31}$. Również wspomniany już Sobór Watykański II, którego wydarzenie i dzieło należy bez wątpienia określić jako epokowe, w rozdziale viI O sztuce kościelnej i sprzętach liturgicznych Konstytucji o liturgii podjął choć niestety bardzo ogólnikowo - temat świętych obrazów:

Należy stanowczo zachować zwyczaj umieszczania w kościołach wizerunków świętych celem oddawania im czci przez wiernych, wszakże w umiarkowanej ilości i we właściwym porządku, aby nie wzbudzały uwielbienia w chrześcijańskim ludzie i nie sprzyjały wypaczaniu pobożności. Przy ocenie dzieł sztuki

\footnotetext{
${ }^{29}$ Por. O. Popova, E. Smirnova, P. Cortesi, Ikony, dz. cyt., s. 10; por. A. Frejlich, Ikona, dz. cyt., k. 9-10.

30 Zob. B. Forte, Maryja. Ikona tajemnicy, Warszawa 1999.

${ }^{31}$ Por. DS 1823-1825.
} 
niech miejscowi ordynariusze zasięgają opinii diecezjalnej Komisji Sztuki Kościelnej, a w razie potrzeby innych wybitnych znawców ${ }^{32}$.

Ten soborowy nakaz powtórzył Kodeks Prawa Kanonicznego z 1983 roku, który w kanonie 1188 potwierdził konieczność zachowania praktyki umieszczania w kościołach świętych obrazów, aby doznawały one czci ze strony wiernych. Z tych dość lakonicznych stwierdzeń Magisterium Kościoła o obrazach możemy wywnioskować, że z jednej strony Kościół zachodni nie odżegnywał się od tego dziedzictwa i bogactwa starożytnego Kościoła, a z drugiej raczej tej spuścizny także specjalnie nie rozwijał.

W tym miejscu słuszną rzeczą będzie przypomnienie wskazań w kwestii ikon kard. Josepha Ratzingera, nie tylko jednego z wybitniejszych teologów katolickich ostatniej doby, lecz także w latach 2005-2013 Chrystusowego Namiestnika na ziemi - jako Benedykta Xvi. W swojej książce od tytułem Duch liturgii, podejmując problem obrazów, definiuje on pięć zasad związków sztuki z liturgią:

1. Całkowity brak obrazów godzi w tajemnicę wcielenia i nie daje się z nią pogodzić. Bóg wkroczył w nasz świat zmysłów. Obrazy piękna, w których uwidacznia się tajemnica niewidzialnego Boga, przynależą do chrześcijańskiego kultu.

2. Obrazy przedstawiające historię zbawienia, począwszy od stworzenia aż po zmartwychwstanie i paruzję, odnajdują swoją treść w sztuce sakralnej. Dzięki niej obrazy biblijne oraz dzieje świętych, które są rozwinięciem historii Jezusa Chrystusa, są nam bliższe i umacniają nas w wierze.

3. Obrazy, ukazujące wspólną historię Boga i ludzi, nie tylko ukazują wydarzenia z przeszłości, lecz także ujawniają wewnętrzną jedność Bożego działania. Historia staje się sakramentem w Chrystusie, który jest Ukrzyżowany, ale i Zmartwychwstały. Obraz Chrystusa jako obraz, którego centrum stanowi Pascha, zawsze jest ikoną Eucharystii, to znaczy wskazuje na sakramentalną obecność tajemnicy paschalnej.

4. Obrazy Chrystusa i świętych nie są fotografiami. Święte obrazy budzą wewnętrzne, duchowe zmysły i uczą nowego spojrzenia, które w widzialnym dostrzega to, co niewidzialne. Sakralność obrazu polega na tym, że obraz wynika $z$ wewnętrznego oglądu i do niego prowadzi; jest owocem wewnętrznej kontemplacji wierzącego, który spotyka nową rzeczywistość Zmartwychwstałego.

${ }^{32}$ KL 125-126. 
5. Kościół zachodni nie musi rezygnować ze swojej specyfiki, którą kształtuje od xıII wieku. Należy jednak przeprowadzić rzeczywistą recepcję uchwał II Soboru Nicejskiego i przestrzegać podstawowych zasad teologii obrazu tam wypracowanych, albowiem w sztuce sakralnej nie może istnieć dowolność. Bez wiary nie będzie istnieć sztuka odpowiadająca liturgii. Sztuki nie można produkować, gdyż jest ona darem - darem nowego spojrzenia ${ }^{33}$.

Odwołajmy się jeszcze raz listu apostolskiego św. Jana Pawła II, ogłoszonego na zakończenie Jubileuszu Roku 200o. Biskup Rzymu zachęcał cały Kościół powszechny, wchodzący w trzecie tysiąclecie, do ponownego odkrycia Chrystusa. A spotkać Jezusa, nowego człowieka (por. Ef 4, 24; Kol 3, 10), oznacza kontemplować Jego oblicze. „Gdy po zakończeniu Jubileuszu powracamy na zwyczajną drogę, niosąc w sercu całe bogactwo doświadczeń, jakich zaznaliśmy w tym niezwykłym okresie, bardziej niż kiedykolwiek wpatrujemy się w oblicze Pana" ${ }^{34}$. Chrystusa Wybawiciela kontemplujemy w ikonograficznym zapisie w tajemnicy Jego oblicza cierpiącego i zmartwychwstałego. „Zmartwychwstały Chrystus, który przyłącza się do nas w drodze i pozwala się rozpoznać - tak jak uczniom z Emaus "przy łamaniu chleba» (por. Łk 24, 35), niech zastanie nas czuwających, gotowych rozpoznać Jego oblicze i spieszyć do braci, aby nieść im wspaniałą

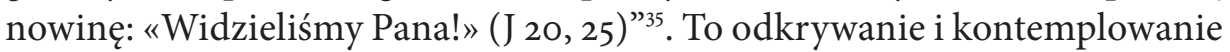
Odkupiciela staje się naszym udziałem, jeśli zaprosimy do pomocy Maryję. Któż bowiem z ludzi lepiej zna oblicze Jezusa niż Jego Matka?

\subsection{Typy ikon maryjnych}

Możemy wyróżnić kilka typów maryjnych ikon. Ogólnie wyróżniamy osiem rodzajów (typów) malarskich przedstawień Matki Jezusa, a niektóre z nich mają jeszcze swoje warianty. Do najbardziej popularnych zalicza się Eleusa (z gr. Czuła, Miłosierna). Jest to przedstawienie tkliwej, subtelnej Maryi z Dzieciątkiem Jezus, siedzącym na Jej ramieniu i przytulającym do Jej twarzy policzek. Znawcy tematu wyróżniają trzy warianty w rodzaju Eleusa:

${ }^{33}$ Por. J. Ratzinger, Duch liturgii, dz. cyt., s. 119-122. Trudno i tutaj nie powtórzyć tego samego zarzutu, który już powyżej został skierowany w stronę Kongregacji ds. Kultu Bożego i Dyscypliny Sakramentów. Szkoda, że ta znakomita książka Ratzingera została opublikowana z tak wielkim opóźnieniem.

${ }^{34}$ NMI 16.

${ }^{35}$ NMI 59. 
Glykophilousa (Czuła, Słodko całująca), Kyriotissa (Matka Pana) lub Nikopoia (Przynosząca zwycięstwo - według cesarza Nikefora) oraz Psychosostria (Ratująca dusze).

Drugim typem jest Hodegetria (gr. Przewodniczka, Wskazująca drogę). Maryja na obrazie wskazuje prawą dłonią na małego Jezusa, którego trzyma na lewym ramieniu. Termin Hodegetria wiąże się ze świątynią w Konstantynopolu (ton Hodegon), gdzie przechowywano najstarszą ikonę tego typu. Klasyczną Hodegetrią jest obraz jasnogórski w częstochowskim sanktuarium paulinów. Typ Hodegetrii, wizerunek Marii i Dzieciątka, ma dwa warianty: Dexiokratousa (z Dzieciątkiem na prawym ramieniu) oraz Tricheirousa (tzw. Trójręczna).

Trzecim rodzajem jest Orantka (Modląca się). Wydaje się, że jest to jedno z najstarszych przedstawień Bogarodzicy, sięgające czasów pierwotnego Kościoła. Kanon Orantki nawiązuje do starożytnego modelu człowieka pobożnego. Stąd Matka Boża w modlitewnym geście wznosi ręce ku górze. Tradycja prawosławna głosi, że kiedy Maryja opuści dłonie, nastąpi koniec świata.

Czwarty typ świętego obrazu maryjnego to Blacherniotissa (Orędowniczka, Modląca się). Kolejny rodzaj ikony to Platytera (Obejmująca). Szósty typ maryjnej ikony to Galaktotrophousa (Karmicielka, Maria lactans). Przedostatni typ to Paraklesis - przedstawienie Maryi bez Dzieciątka. Jej atrybutem jest zwój pisma. Ósmy typ ikony to Pelagonitissa - wyobrażenie Marii z bawiącym się Dzieciątkiem Jezus.

Ikonografia Matki Chrystusa nie tylko jest niezwykle pięknym i bogatym wyrazem czci do Przebłogosławionej, lecz także stanowi doskonałe źródło Jej poznania. W duchowości wschodnich chrześcijan nie spotyka się maryjnych figur czy rzeźb, stąd kult wyobrażeń ukazywanych w świętym obrazie cechuje tu o wiele głębszy sens niż na Zachodzie. Wschodnia teologia wręcz utożsamia ikonę ze słowem. Przez obraz i słowo człowiek może poznawać rzeczywistość. Obraz stanowi istotę chrześcijaństwa, gdyż nie ogranicza się ono tylko do objawienia starotestamentalnego Boga Ojca - Słowa, ale poszerza objawienie do Boskiego wizerunku, cielesnego Boga - Człowieka w Chrystusie. To poznanie przez ikonę nie jest tylko aktem psychicznym, lecz także sakramentalnym uobecnieniem świętej osoby, ukazywanej na obrazie $^{36}$.

${ }^{36}$ Por. J. Błaszczyszyn, Maryja w Prawosławiu, „Nurt svd. Kwartalnik Misjologiczno-Religioznawczy” 28 (1994) nr 4, s. 53-61; zob. T. D. Łukaszuk, Ikona w życiu, w wierze i w teologii Kościoła, Kraków 2008; L. Uspienski, Teologia ikony, tłum. M. Żurowska, Poznań 1993. 


\section{Mariologia ekumeniczna}

Według ogólnego przekonania nauka Kościoła katolickiego o Maryi i praktykowana w Kościele cześć w stosunku do Najświętszej Dziewicy stanowi jedną z ważniejszych przeszkód w dialogu ekumenicznym. Przypatrzmy się więc pokrótce, jak wygląda mariologia i maryjność głównych wyznań chrześcijańskich w porównaniu z myślą Kościoła katolickiego. Następnie zaprezentujemy podstawowe osiągnięcia dialogu ekumenicznego w interesującym nas zakresie. Rozdział Mariologia ekumeniczna zakończy skromna próba naszkicowania ekumenicznych perspektyw, czyli rozstajów i zbliżeń.

\subsection{Prawosławie i Przebłogosławiona}

Kościół prawosławny odznacza się niezwykle głęboką pobożnością maryjną. Znajduje ona odbicie w liturgii i sztuce Wschodu. Centralne miejsce $\mathrm{w}$ ikonostasie cerkiewnym zajmuje z jednej strony postać Chrystusa, a z drugiej Maryi z Dzieciątkiem. Kościół wschodni widzi w Maryi swój własny prototyp i w Jej osobie dostępuje tajemnicy wypełnienia swojego Boskiego powołania. W liturgii Kościołów wschodnich jest zawsze obecna Maryja i wspomnienie Jej roli w Bożej ekonomii zbawienia. Nie ma uroczystości czy święta, nie ma rytu sakramentalnego czy błogosławieństwa, nie ma modlitwy bez wezwania „Najświętszej, Przeczystej, Przebłogosławionej, Chwalebnej, Pani naszej, Bogurodzicy zawsze Dziewicy"'.

Na temat doktryny i kultu maryjnego w prawosławiu por. obszerna monografia Prawosławie. Światło ze Wschodu, red. K. Leśniewski, Lublin 2009, s. 67-142. 
Po zerwaniu łączności między chrześcijaństwem Wschodu a Zachodu prawosławni nie odważyli się dodać niczego do cennego dziedzictwa wyniesionego ze wspólnego tysiącletniego dorobku wiary. Kościół prawosławny broni się przed jakąkolwiek systematyzacją czy dogmatyzacją swojej nauki o Matce Chrystusa. Prawdy o wcieleniu Boga i przebóstwieniu człowieka (perychoreza), jak również uwielbieniu czy przemienieniu całego kosmosu, przeżywane przez chrześcijaństwo wschodnie jako centralne, winny być według teologów Wschodu wyrażone nie przez analizę i systematykę, ale w języku symbolu i obrazu, który jest wprawdzie mniej precyzyjny, ale za to bardziej adekwatny do niezgłębionej tajemnicy Boga. Właściwa jednak introdukcja w teologiczną myśl wschodnią (jej trynitologię, chrystologię, pneumatologię, eklezjologię, soteriologię i eschatologię oraz w jej doświadczenie liturgiczne i duchowe) wiedzie przez antropologię. Dlatego zrozumienie osoby Maryi i Jej miejsca w myśli prawosławnej wynika z koncepcji antropologicznej, wypracowanej przez takich myślicieli jak Włodzimierz Sołowiew, Paweł Florenski, Siergieja Bułgakow, Mikołaj Bierdiajew, Włodzimierz Łosski, Panayiotis Nellas, Nikos Nissiotis, Joannis D. Zizioulas, Christos Yannaras².

Prawosławna refleksja filozoficzno-teologiczna głosi, że lepiej, aby misterium chrześcijańskiej wiary było nie do końca wypowiedziane niż nadmiernie zracjonalizowane. Dlatego też prawosławie nie prezentuje się jako ściśle określony system doktrynalny. Akcentuje mocniej duchowe doświadczenie żywego Boga w liturgii, śpiewie, sakramentach, słowie Bożym i ikonie. Teologię i duchowość karmi żywotami świętych, nauczaniem ojców i nauczycieli Kościoła, dekretami pierwszych siedmiu soborów niepodzielonej Wspólnoty. Wschodnia teologia chętnie łączy się z mistyką. W takim ujęciu Najświętsza Maryja Panna jawi się jako skuteczny znak Bożego zbawienia, podarowany światu³.

Zgodnie z najstarszą tradycją chrześcijaństwa pierwszego tysiąclecia Kościół prawosławny odnosi się do Matki Jezusa na sposób doksologiczny, a nie czysto refleksyjny czy intelektualny. W konsekwencji myśl prawosławna wypływa z kultu i pobożności ludowej. Stosuje się do Przebłogosławionej szczególnie dwa tytuły: Theotokos (Bogarodzica) i Panhagia (Cała Święta),

2 Por. K. Leśniewski, „Kim jest człowiek, że o nim pamiętasz...?” Podstawowe idee współczesnej antropologii prawosławnej, Lublin 2015, s. 19-21, 109-133 (Światło Przemienienia, 8).

3 Por. Maximos (Aghiorgoussis), Wiara Kościoła, [w:] Prawosławie. Światło ze wschodu, dz. cyt., s. 29. 
i umieszcza Ją tym samym w centrum Ludu Bożego i wspólnoty świętych. Tajemnica Maryi rozważana jest w ścisłej łączności z tajemnicą Chrystusa. Mariologia Kościoła prawosławnego dostrzega szczególną rolę Ducha Świętego w tajemnicy Chrystusa i Maryi. Podkreśla ścisły związek między zwiastowaniem a zesłaniem Ducha Świętego. Dopełnieniem wybrania Maryi jest bowiem Jej rola w społeczności Kościoła. Maryja jest pierwszym członkiem Kościoła, a równocześnie Matką wszystkich wierzących. Prawosławie widzi w Niej również „archetyp ostatecznego wypełnienia”, gdyż jest Ona uosobieniem Ludu Bożego końca czasów.

Szczególną rolę w pobożności prawosławia odgrywają niezliczone ikony Matki Bożej z Dzieciątkiem, tak w cerkwiach, jak i domach prywatnych. Według teologii prawosławnej Chrystus, przyjmując ciało z Maryi, sprawił, że zniekształcony przez grzech obraz Boga w człowieku został zmieniony w obraz pierwotny. Maryja ma w tym dziele zbawienia podwójny udział. Przez swoje fiat wypowiedziane przy zwiastowaniu umożliwiła przywrócenie pierwotnego obrazu Boga w człowieku, z kolei sama stanowi praobraz wszelkiego przeobrażenia, czyli odkupienia. Dlatego prawosławna ikona przedstawia, uobecnia i głosi rzeczywistość zbawienia ${ }^{4}$.

Przeczysta Dziewica zajmuje znaczące miejsce w liturgii Wschodu. $\mathrm{Na}$ dwanaście największych świąt aż pięć to święta maryjne: Narodzenie Maryi (8 września), Wprowadzenie do Świątyni (21 listopada), Spotkanie Pańskie (2 lutego), Zwiastowanie (25 marca) i Zaśnięcie (15 sierpnia). Dopełnieniem jest znaczna liczba świąt mniejszych. Obecność Bożej Rodzicielki w liturgii widoczna jest także w celebracji eucharystycznej, kiedy to imię Maryi przyzywane jest kilkakrotnie, a Jej osobę symbolizuje w czasie obrzędu przygotowania darów jedna z cząstek chleba. Co więcej, imię Theotokos spotykamy w samej anaforze (modlitwie eucharystycznej). Obecność Matki Pana w celebracji eucharystycznej ma świadczyć o prawdziwości wcielenia. Najpiękniejszego członka Kościoła nie mogłoby przecież zabraknąć w Eucharystii, która jest modlitwą zanoszoną do Ojca Niebieskiego przez Jezusa. Maryja przywołuje w Eucharystii Ducha Świętego, którego obecność jest niezbędna, aby chleb i wino przemieniły się w Ciało i Krew Jezusa Chrystusa. Prawosławni sławią przeczystą Dziewicę

4 Por. Z. J. Kijas, Analiza prawosławnej mariologii na podstawie lektury trzech ważnych tekstów, „Polonia Sacra” 2002 nr 11, s. 21-38; J. Klinger, Zarys prawosławnej mariologii, [w:] tenże, O istocie prawosławia. Wybór pism, Warszawa 1983, s. 209-247. 
$\mathrm{w}$ innych jeszcze formach swojej liturgii, ponadto w sakralnej muzyce, śpiewie, poezji i sztuces.

\subsection{Ewangelicy a Matka Pana}

Protestantyzm polemizuje z katolickim ujęciem nauki o Maryi, a zwłaszcza z zasadnością kultu maryjnego. Cześć oddawana Maryi uważana jest powszechnie za element odróżniający oba wyznania chrześcijańskie. Sam Luter nie odrzucił wprawdzie od razu kultu maryjnego i przyjmował najważniejsze dogmaty maryjne ${ }^{6}$.

Zdaniem ewangelickiego teologa Hansa Asmussena nie ma drugiego zagadnienia, które tak dzieliłoby wyznania, jak mariologia ${ }^{7}$. Trudno się jednak zgodzić z tą uproszczoną i obiegową tezą, gdyż istotą reformacji nie był wcale spór o Matkę Pana. Świadczy o tym to, że wśród dekretów Soboru Trydenckiego nie ma żadnego poświęconego w całości Maryi. Ten brak dekretu o Matce Pana wskazuje jednoznacznie, że w związku z jej kultem nie było punktów spornych. Reformatorzy szanowali obowiązujące wtedy trzy dogmaty maryjne: o Bożym macierzyństwie, o Jej dziewictwie, o świętości i bezgrzeszności. Niepokalane poczęcie i wniebowzięcie nie były wtedy jeszcze zdogmatyzowane. Reformacja nie wystąpiła więc przeciwko dogmatom maryjnym, lecz przeciwko przerostom i nadużyciom w kulcie maryjnym. Oddają to słowa Lutra z Komentarza do Magnificat, w którym pisze on: „Maria nie chce być bożkiem. Maria nie czyni niczego, Bóg jest sprawcą wszystkich rzeczy. Należy Marię przyzywać, aby Bóg przez jej wolę udzielił nam wszystkiego, o co prosimy". W tym Komentarzu Luter przyzywa nawet Maryję słowami: „Święta Dziewico i Matko Boga”. Te dwa tytuły wyrażają prawdy chrześcijańskiej wiary, zdogmatyzowane jednak jeszcze przed Xvi wiekiem9.

5 Zob. A. Kniazeff, Matka Boża w Kościele prawosławnym, przeł. H. Paprocki, Warszawa 1996 (Theotokos, 7); N. Nissiotis, Maryja w teologii prawosławnej, [w:] Prawosławie. Światło ze wschodu, dz. cyt., s. 80-83.

6 Por. W. Życiński, Prawda o Bożym macierzyństwie Maryi. Perspektywa ekumeniczna, SM 2 (2000) nr 1, s. 201-214.

7 Por. S. C. Napiórkowski, Maria w ewangelicyzmie, [w:] Religia. Encyklopedia PWN, t. vi, red. T. Gadacz, B. Milerski, Warszawa 2002, s. 425.

8 M. Luter, Komentarz do Magnificat, dz. cyt., s. 135 i 133.

9 Por. B. Ferdek, Dialog o Matce Pana w kontekście różańca, sm 5 (2003) nr 1, s. 220-232. 
Dla uzupełnienia obrazu należy zauważyć, że w miarę upływu czasu główne zasady protestantyzmu odcisnęły jednak negatywne piętno na stosunku chrześcijaństwa ewangelickiego do mariologii i czci maryjnej. Zasada solus Christus w ekskluzywnym rozumieniu wyznawała, że wszelki współudział w dziele zbawienia pomniejsza godność Chrystusa, jedynego Pośrednika i Arcykapłana. Tak samo zasada sola scriptura rozumiana była jako przeciwstawienie się kościelnej Tradycji i interpretacji Magisterium Kościoła. To, czego wyraźnie nie ma w Piśmie Świętym, odrzuca się jako wymysł ludzki, zniekształcający objawienie Boże. Z kolei zasada sola gratia rozumiana była na tle przekonania o całkowitym zepsuciu ludzkiej natury przez grzech pierworodny i niemożliwości jakiegokolwiek współdziałania człowieka z łaską Bożą. W odniesieniu do Maryi zasada ta prowadzi do odrzucenia przekonania o Jej świętości i współdziałaniu w dziele odkupienia.

Radykalizm protestanckich tez prowadził do faktycznego postawienia pod znakiem zapytania pełnego realizmu wcielenia. Z pozycji katolickiej trudno się z tym zgodzić. Skoro Chrystus rzeczywiście stał się człowiekiem, to wszystko, co ludzkie, nie może być już odtąd traktowane jako bezwartościowe przed Bogiem. Co więcej, musi być włączone w dzieło Bożego zbawienia. Jeżeli dotyczy to każdego człowieka, to tym większe znaczenie ma w wypadku człowieka, który w sposób jedyny i niepowtarzalny włączony został w tajemnicę wcielenia. Tym człowiekiem jest Matka Odkupiciela.

Aby osiągnąć kompetentny obraz zagadnień mariologicznych i maryjnych w protestantyzmie, należałoby podjąć analizę piśmiennictwa $\mathrm{M}$. Lutra oraz Ksiąg Symbolicznych luteranizmu, będących dla Kościoła ewangelicko-luterańskiego norma normata, a zatem uwzględnić ich nauczanie o Matce Jezusa. Chodzi tu zatem o teksty Konfesji Augsburskiej (Confessio Augustana), Apologii Konfesji Augsburskiej, Artykuły Szmalkaldzkie i Formułę Zgody (Formula Concordiae). W niniejszej części ograniczamy się naturalnie do głównych wytycznych ewangelickiej teologii ${ }^{10}$.

Jakkolwiek protestantyzm nie posiada odrębnej dyscypliny w rozumieniu katolickiej mariologii jako samodzielnego traktatu dogmatycznego, to jednak główne jego tezy o Maryi - według ks. Jana Grosa, polskiego

${ }^{10}$ W skład Luterańskich Ksiąg Symbolicznych wchodzą następujące pisma: Konfesja Augsburska (1530), Apologia Konfesji Augsburskiej (1531) Artykuty Szmalkaldzkie (1537), Traktat o władzy i prymacie papieża (1537), Mały katechizm Lutra (1529), Duży katechizm Lutra (1529), Formuła Zgody (1577). Przekład polski to Wybrane Księgi Symboliczne Kościoła Ewangelicko-Augsburskiego, przeł. A. Wantuła, W. Niemczyk, Warszawa 1980. 
duchownego luterańskiego - można sprowadzić do następujących stwierdzeń: Maryja Panna jest dla ewangelików Matką Bożą - Bogarodzicą, jest świętą, czystą zawsze Dziewicą, jest Najchwalebniejszą i najgodniejszą najwyższej czci ze wszystkich kobiet żyjących w przeszłości, teraźniejszości i przyszłości na ziemi. Dla luteranów nie jest jednak ani Orędowniczką, ani Współodkupicielką, ani Królową niebios i ziemi, ani Niepokalanie Poczętą i Wniebowziętą.

Natomiast we współczesnym kulcie luterańskim imię Marii Panny wymieniane jest $\mathrm{w}$ każdym ewangelickim nabożeństwie niedzielnym i świątecznym, w czasie wspólnego odmawiania wyznania wiary apostolskiej lub nicejsko-konstantynopolitańskiej. Kalendarz liturgiczny Kościoła ewangelicko-augsburskiego zawiera trzy święta „maryjne”, posiadające własne proprium de tempore: Oczyszczenie Maryi Panny (2 lutego), Zwiastowanie Maryi Pannie (25 marca), Nawiedzenie Maryi Panny (2 sierpnia). W niektórych luterańskich świątyniach (np. w Polsce i w Czechach) odprawiane są jeszcze nieszpory, zwłaszcza w ewangelickich diakonatach, w zgromadzeniach sióstr (Marienschwesternschaft, Darmstad), na konferencjach księży, w męskich diakonatach i zgromadzeniach braterskich. Nieszpory te odprawiane są według najstarszej liturgii godzin, czyli ze śpiewem Magnificat ${ }^{11}$.

W niektórych odłamach współczesnego protestantyzmu pojawiają się pewne tendencje odwrotu od minimalizmu maryjnego, otwierające możliwość dialogu z teologią katolicką, która z kolei stara się mocniej oprzeć naukę o Maryi na fundamencie biblijnym i rozważać Ją w łączności z głównymi zagadnieniami wiary w Jezusa Chrystusa. Momentem kluczowym dla dialogu ekumenicznego ze strony katolickiej było otwarcie wyrażone postanowieniami Soboru Watykańskiego II, integrującymi teologię maryjną z tajemnicą Chrystusa i Kościoła. Coraz wyraźniejsza staje się tęsknota braci ewangelików za Matką Jezusa ${ }^{12}$. Zasady odnowy czci oddawanej Maryi zaproponowane w Marialis cultus Pawła vi są przełożeniem na język praktyki duszpasterskiej ekumenicznych wskazań Soboru. Ważnymi gestami były ponadto encykliki świętego papieża z Polski: maryjna Redemptoris Mater z 1987 roku oraz ekumeniczna Ut unum sint z 1995 roku. W świecie protestanckim mocno komentowano konwersję na katolicyzm znakomi-

${ }^{11}$ Por. J. Gros, Mariologia luterańska, [w:] Nosicielka Ducha, Pneumatofora..., dz. cyt., s. 101-111.

${ }_{12}$ Por. A. Wojtczak, Protestancka tęsknota za Maryją, sm 13 (2011) nr 3-4, s. 359-365. 
tych osobistości Kościołów ewangelickich: Maxa Thuriana i Christy Meves, którzy zdecydowali się na ten odważny krok pod wrażeniem wspomnianych encyklik.

Brat Roger, który notabene pochodził z rodziny protestanckiej, wspólnie z Matką Teresą z Kalkuty napisał książkę Maryja, Matka Pojednania ${ }^{13}$. Brat Roger postrzegał Kościół jako wspólnotę świętych, gdzie również Maryja ma szczególne miejsce.

Franciszek Werfel, pisarz austriacki żydowskiego pochodzenia, ścigany przez hitlerowskich prześladowców, zetknął się w Lourdes z historią objawień Matki Boskiej. Szczęśliwie ocalony, napisał książkę Pieśń o Bernadecie ${ }^{14}$, w której sławi imię Maryi. Takie przykłady można zresztą mnożyć.

Po stronie protestanckiej widać obecnie umiarkowane odnowienie zainteresowania Maryją. Wśród teologów wykazujących szczególne wyczulenie na problematykę mariologiczną wymienia się Wilhelma Stählina, Hansa Asmussena, Lukasa Vischera, Ulricha Wickerta. Nie brak w łonie protestantyzmu inicjatyw zmierzających do ubogacenia ruchu ekumenicznego refleksją na tematy maryjne, takich jak np. założone w Anglii w roku 1967 Ekumeniczne Stowarzyszenie Najświętszej Maryi Panny. Niektórzy teologowie protestanccy biorą udział w pracach międzynarodowych kongresów mariologicznych, które organizuje Papieska Akademia Mariologiczna, podpisując końcowe deklaracje mariologiczno-ekumeniczne. Tak było np. na Kongresie w Rzymie (1975), w Saragossie (1979), w Meksyku (1983). Dokument grupy roboczej Zjednoczonego Ewangelicko-Luterańskiego Kościoła w Niemczech pod tytułem Maryja - ewangelickie zapytania i punkty widzenia. Zaproszenie do dialogu z 1979 roku stwierdza, że Maryja niesłusznie poszła w zapomnienie, i podkreśla, że nie sposób wyłączyć Matkę Chrystusa z danych objawienia i dziedzictwa Tradycji. Ponadto przyznaje, że nie każda teologia maryjna i nie każdy sposób oddawania czci Matce Chrystusa jest elementem dzielącym chrześcijańskie Kościoły ${ }^{15}$.

${ }^{13}$ Matka Teresa z Kalkuty, brat Roger z Taizé, Maryja, Matka Pojednania, tłum. z fr. M. Adamczyk, Katowice 1988.

${ }^{14}$ F. Werfel, Pieśn o Bernadetcie, przeł. M. Kłos, Poznań [b.r.].

${ }^{15}$ Por. A. Skowronek, Zagadnienia maryjne $w$ dialogu ekumenicznym, dz. cyt., s. 370-374. 


\subsection{Współczesny dialog chrześcijan}

Dialogi, jakie prowadzą między sobą chrześcijanie, dotyczą zasadniczo wszystkiego, co związane jest $\mathrm{z}$ ich religijnym życiem i z doktryną samych Kościołów, jak również z problemami, trudnościami czy nadziejami świata. Oprócz zagadnień społecznych i ogólnoludzkich Kościoły poruszają kwestie, które stały się źródłem ich historycznych podziałów i nadal stanowią poważną trudność we wzajemnych relacjach i w budowie jednej widzialnej Wspólnoty Jezusa Chrystusa. Z Kościołami prawosławnymi katolicy rozmawiają przede wszystkim na temat pochodzenia Ducha Świętego (Filioque czy per Filium), prymatu papieża i jego nieomylności, tajemnicy Kościoła i jego jedności, wzajemnego uznawania sakramentu małżeństwa, dogmatów maryjnych czy czyśćca oraz modeli jedności ${ }^{16}$.

Z kolei dialog katolicko-anglikański skupia się na problemie natury Kościoła i jego jedności, na sukcesji i sakramencie kapłaństwa, na roli biskupa Rzymu w przyszłym, zjednoczonym Kościele chrześcijańskim. Podejmuje się także kwestie pozostałych sakramentów, szczególnie Eucharystii, jak również przyczyn rozejścia się obydwu Kościołów, zwracając przy tym uwagę na przyczyny pozateologiczne.

W rozmowach z Kościołami tradycji protestanckiej katolicy podejmują kwestię Tradycji i jej aktualności oraz wartości w życiu kościelnym. Tematami rozmów są: sama postać Maryi, Matki Pana, dogmaty maryjne, obecność Maryi w kulcie i pobożności katolickiej. Istotne są także problematyka sakramentu kapłaństwa i Eucharystii, natury urzędu duchownego i prymatu papieża, znaczenia ludzkich uczynków w świetle osiągnięcia zbawienia, usprawiedliwienie oraz kwestia odpustów. Kościół katolicki prowadzi dialog również z innymi wspólnotami chrześcijańskimi, które określają się jako Kościoły „wolne”. Tematami tych rozmów są sakrament chrztu, rola Ducha Świętego, Jego znaczenie dla życia wiary, znaczenie i wartość Tradycji dla życia wiary, charakter Kościoła i sakramentalnego urzędu.

Mimo stosunkowo niedługiego okresu czasu, w jakim prowadzony jest ekumeniczny dialog, a przy tym koncentracji na zasadniczych elementach podziału chrześcijan, istnieje już pokaźna literatura na temat ekumenicznej

${ }^{16}$ Jeśli chodzi o osiągnięcia dialogu ekumenicznego, warto zapoznać się z Ut unum sint. Dokumenty Kościoła katolickiego na temat ekumenizmu 1982-1998, red. S. C. Napiórkowski, K. Leśniewski, J. Leśniewska, Lublin 2000. 
mariologii ${ }^{17}$. Wprawdzie dociekania ekumeniczne dotyczące Matki Pana odsyłają do rozstrzygających problemów doktryny o usprawiedliwieniu, o łasce, o wspólnocie Kościoła, niemniej jednak w niektórych ustaleniach spotyka się też stanowiska katolicko-protestanckie traktujące o zagadnieniach mariologicznych, jak np. kwestia maryjnego pośrednictwa zaproponowana przez ekumeniczną Grupę z Dombes ${ }^{18}$. Mariologia i ekumenizm są zatem dzisiaj dość nieźle - jak na tak młodą dyscyplinę - opracowa$n e^{19}$. Przykładowo można wskazać na pracę zbiorową w języku włoskim pod tytułem Maria nella comunità ecumenica, będącą tego miarodajnym przykładem ${ }^{20}$. Jej swoistego rodzaju uaktualnieniem jest pozycja Stefano De Fioresa, który w drugim wydaniu swojej książki podaje najnowszą bibliografię na temat mariologii w ekumenicznej perspektywie ${ }^{21}$. Istnieje też bibliografia opracowań prawosławnych sporządzona przez Nikosa Nissiotisa $^{22}$ oraz bibliografia protestancka opracowana przez Gottfrieda Marona $^{23}$.

Pomimo zaawansowanych dialogów ekumenicznych, które niestety tak słabo są wcielane w życie Kościołów, istnieje wciąż wiele jednostronności w ujmowaniu mariologii we wszystkich chrześcijańskich konfesjach należących do jednego Kościoła Chrystusowego. Najbliżej jest katolikom do porozumienia z prawosławnymi w tej kwestii. Oni są gorliwymi czcicielami Matki Jezusa. Wysławiają Maryję przepięknymi modlitwami, wystarczy choćby

17 Por. A. A. Napiórkowski, Mariologia w dialogu katolicko-protestanckim, sM 3 (2001) nr 4, S. 91-111.

${ }_{18}$ Por. tenże, Pośrednictwo Maryi w maryjnym dokumencie Grupy z Dombes, sm 4 (2002) nr 3 (15), s. 217-231.

19 Doskonałą syntezę tej tematyki (na uwzględnienie zasługuje zwłaszcza zaprezentowany tu przegląd bibliograficzny) podaje S. C. Napiórkowski, Ecumenismo, [w:] Nuovo Dizionario di Mariologia, a cura di S. De Fiores, Milano 1985, s. 518-527.

${ }^{20}$ Por. Maria nella comunità ecumenica, a cura di Segretariato Attività Ecumeniche, Roma 1982; por. B. Forte, Maryja, ikona tajemnicy, dz. cyt., s. 142-149; por. G. Voss, Mariologie und Marienverehrung, [w:] Handbuch der Ökumenik, Hrsg. H. J. Urban und H. Wagner, Bd. III/2, Paderborn 1987, s. 251-258.

${ }^{21}$ Por. S. De Fiores, Maria nel dialogo ecumenico post-conciliare, [w:] tenże, Maria nella teologia contemporanea, Roma 1987, s. 230-255; tenże, Maria e il mistero del male, a cura di S. M. Perrella, Milano 2013.

${ }^{22}$ Por. N. Nissiotis, Maria della teologia ortodossa, „Concilium. Rivista Internazionale di Teologia” 19 (1983), s. 66-91.

${ }^{23}$ Por. G. Maron, Maria nella teologia protestante, „Concilium. Rivista Internazionale di Teologia” 19 (1983), s. 92-105. 
wspomnieć Akathistos jako najstarszy i najpiękniejszy hymn w całej literaturze chrześcijańskiej. Czczą Maryję - zgodnie z dogmatycznymi ustaleniami z Efezu z 431 roku - jako Najświętszą Bożą Rodzicielkę. Chętnie modlą się przed ikoną Matki Bożej Jasnogórskiej, ponieważ wierzą, że Maryja jest w niej obecna na sposób sacramentale. Wierzą także w zaśnięcie Matki Bożej i przyjmują, że była ona cała święta (panhagia). Odrzucają jednak katolickie dogmaty o niepokalanym poczęciu i wniebowzięciu, gdyż uważają, że papieżowi jako biskupowi odłączonego Kościoła nie przysługuje prawo do definiowania prawd wiary i narzucania ich całemu chrześcijaństwu ${ }^{24}$.

$\mathrm{Z}$ wypracowanych propozycji luterańsko-katolickiego zbliżenia w zakresie mariologii trzeba przywołać projekt roboczej grupy Catolica, która działa w ramach Zjednoczonego Ewangelicko-Luterańskiego Kościoła Niemiec (VELKD). Po latach intensywnych wewnątrzkościelnych dyskusji grupa opublikowała dokument zatytułowany Maryja - ewangelickie zapytania i punkty widzenia. Zaproszenie do dialogu. Ten zapewne pierwszy w naszych czasach tak wysokiego szczebla dokument jest niemal nieznany poza wąskim gronem ewangelickich i katolickich specjalistów ekumenistów. Został on pomyślany jako materiał do refleksji dla katolików i protestantów. Pokłosie dokumentu okazało się tak obfite, iż opracowanie materiałów zajmie Komitetowi Centralnemu veLKD kilka lat.

Wymowne są już tytuły rozdziałów tego dokumentu-projektu: 1. Chrześcijanie ewangeliccy w obliczu pytania o Matkę Jezusa; 2. Maryja w Nowym Testamencie; 3. Wspólne dziedzictwo chrześcijańskie; 4. Główne motywy i linie rozwojowe mariologii; 5. Właściwości mariologii rzymskokatolickiej; 6. Punkty widzenia dla ewangelickiego rozumienia Maryi. Tok wywodów unika polemiki, usiłuje natomiast przedstawić orędzie ewangelijne bez uprzedzeń i zawężeń, ale niezależnie od jakichkolwiek konstrukcji spekulatywnych nanoszonych na dane biblijne. Protestanci akcentują swą więź z Tradycją, przede wszystkim z Tradycją pierwszych pięciu wieków (Traditio quinquesaecularis), której treści mierzone winny być jednak zawsze normą Ewangelii.

Z danych objawienia i Tradycji razem wziętych nie sposób wyłączyć myśli o Maryi. Maryjna powściągliwość protestantyzmu, co niejednokrotnie podkreślane, stanowi zrozumiały rezultat tego, iż Maryja stała się silnym wyrazem katolickiej tożsamości. Równocześnie stwierdza się, że „nie każda mariologia i nie każdy kult maryjny będą czynnikami dzielącymi Kościoły”.

${ }^{24}$ Por. A. A. Napiórkowski, Jedność konsekrowana, Kraków 2002, s. 87 (Collectio ViCo, 3). 
Maryja należy do objawienia „oczywiście nie jako objawienie słowa Bożego, lecz jako stosowna ludzka odpowiedź na słowo Boże".

Ostatecznie należy zauważyć, że projekt VELKD pozostaje krytyczny wobec trzech problemów: pośrednictwa, niepokalanego poczęcia oraz wniebowzięcia. Największą uwagę przykuwa zagadnienie pośrednictwa Maryi. Ewangelicy nie mogą pozbyć się podejrzenia, że człowiek - reprezentowany przez Maryję - w jakiś sposób sam może współdziałać z Bogiem w sprawieniu własnego zbawienia. Jest to swego rodzaju zaproszenie ze strony protestantów, ażeby katolicy zrezygnowali z wyrażenia „współodkupicielstwo Maryi”. To prawda, że teologowie czynią mnóstwo rozróżnień i zastrzeżeń odnośnie do udziału Matki Jezusa w dziele zbawienia, niemniej wciąż jest to trudne zagadnienie. Podkreślać należy przede wszystkim nieustannie to, iż Kościół katolicki nigdy nie przypisywał Maryi „niezależnej” roli w funkcji odkupienia. W porządku łaski „współpracować” znaczy zawsze „udzielać odpowiedzi". Uczestnictwo Maryi w dziele zbawienia nie jest aktem uzupełniającym dzieło Chrystusa, lecz stanowi owoc łaski otrzymanej i rozwija swą aktywność pod wpływem łaski i w łasce. Tylko przy tym założeniu Maryja wypowiedziała fiat, włączając się w ten sposób w uczestnictwo tajemnicy zbawienia. Odkupienie jest w stu procentach dziełem samego Chrystusa, które zaowocowało w Maryi, pełnej łaski. Dzięki współpracy z darami otrzymanymi w swej wierze, w posłuszeństwie i służbie Maryja, Boże stworzenie, jawi się jako autentyczna partnerka Boga ${ }^{25}$.

Protestanci - trzymając się zasady sola scriptura - odrzucają wszystko, czego nie można uzasadnić tekstem Pisma Świętego. Maryja to dla nich Matka Pana. Nie negują Jej Bożego rodzicielstwa, ale nie widzą także żadnego biblijnego uzasadnienia, aby Ją czcić i przyzywać jako Orędowniczkę. Luteranie nie znają bowiem modlitw do świętych, nie wzywają też ich wstawiennictwa ani orędownictwa, ponieważ według nich jedynie przez Jezusa Chrystusa istnieje wolny i pełny dostęp do tronu łaski Bożej. Protestanci są w pewnym sensie zubożeni w swojej pobożności przez brak macierzyńskiej, pełnej ciepła i wyjątkowej serdeczności, obecności Maryi. Dając wyraz takiemu myśleniu, luterańska biskupka, Maria Jepsen z Hamburga, w pierwszych dniach stycznia 2001 roku wezwała ewangelickich chrześcijan do ponownego odkrycia Maryi. Według niej wielu chrześcijan swoje wyobrażenie o Matce Bożej zbudowało jedynie na podstawie artystycznej sztuki czy chorałowego śpiewu, ponieważ zdystansowali się od kościelnej

${ }^{25}$ Por. A. Skowronek, Zagadnienia maryjne $w$ dialogu ekumenicznym, dz. cyt., s. 370-374. 
tradycji maryjnej. Od Maryi możemy się nauczyć głębokich, ludzkich relacji, wewnętrznego zawierzenia i pełnych miłości spojrzeń na człowieka.

Ekumenizm jest sprawą bardzo delikatną, szczególnie w swoich mariologicznych wymiarach. Ale czyż nie jawi się to dla nas, katolików, jako wyzwanie, aby pomóc innych braciom chrześcijanom odkrywać Maryję? Aby i oni doświadczyli jej miłości, do której myśmy się już przyzwyczaili? Nie utrudniajmy zatem innym dotarcia do Matki Pana fałszywą pobożnością, która może innych zrażać. Dzisiejsze poprawne teologiczne mówienie o Maryi jest refleksją wypływającą przede wszystkim z tajemnicy Chrystusa i Kościoła. Współczesna orientacja mariologii, jako chrystotypiczna i eklezjotypiczna, musi jednak podążać w kierunku bardziej integralnym ${ }^{26}$.

Dla nas, dążących do tego, aby właściwie czcić Najświętszą Maryję Pannę, ważną sprawą jest zdrowa pobożność, niezredukowana tylko do emocji. Jeśli rzeczywiście zależy nam na prawdziwej miłości do świętej Bożej Rodzicielki, to nabożeństwa do Niej nie będziemy odrywali od tajemnicy Chrystusa i Kościoła i umieszczali go poza integralną wizją dziejów zbawienia. Nie można dopuszczać do atomizacji mariologii, gdyż wyobcowanie jej z kontekstu całej teologii sprowadza ją na błędne tory i pozbawia ostatecznie wymiaru chrystocentrycznego i eklezjologicznego. Mariologia nie może być ustawiana na jakimś separatystycznym, teologicznie odosobnionym podeście, ale musi wypływać z nauczania Magisterium Kościoła. Z pewnością nie tylko ułatwi to ekumeniczny dialog, lecz także zachęci innych wyznawców Chrystusa do uznania Jego Matki w porządku duchowym za swoją własną. Boża Rodzicielka jest przecież dla wszystkich chrześcijan. Ona jako najwspanialsza uczennica Pańska - rodzi nieustannie wszystkich dla Chrystusa. Jej wiara przymnaża wiary innym. W Kanie Galilejskiej to Ona rzekła do sług na weselu: „Zróbcie wszystko, cokolwiek wam powie [...]. I uwierzyli w Niego Jego uczniowie" (J 2, 1-11) ${ }^{27}$.

Powyższą myśl pięknie oddaje św. Augustyn z Hippony, gdy w jednym ze swoich kazań głosi, że:

Człowiek - Zbawiciel nasz (1 Tm 2, 5) [...] z Ojca urodzony stworzył Matkę, a zrodzony z Matki, uwielbił i Ojca. Jednorodzony u Ojca bez narodzenia z niewiasty, Jednorodzony u Matki bez połączenia z mężem. Ten jest urodziwy przed synami ludzkimi (Ps 45, 3), Syn Maryi, Oblubieniec świętego Kościoła, którego

\footnotetext{
${ }^{26}$ Por. tamże, s. 88.

${ }^{27}$ Por. tamże, s. 92.
} 
uczynił na podobieństwo Rodzicielki swojej. Albowiem i uczynił nam Kościół Matką i strzeże jego dziewictwa. Kościół i Maryja mają wieczną czystość i nieskazitelną płodność. Albowiem Maryja zyskała to w ciele, co Kościół zachował w umyśle, a mianowicie, że Ta zrodziła Jednorodzonego, a ten zrodził licznych.

Maryja to żywy znak miłości Boga do człowieka dzięki wybraństwu w Duchu Świętym do zrodzenia odwiecznego Syna Bożego i dzięki swojemu przyzwoleniu. Jej „tak” do dzisiaj czyni ją płodną w porządku wiary jako Matkę wszystkich wierzących w jej Syna. Jeśliby bowiem zabrakło synowskiej miłości do Maryi w jakimkolwiek chrześcijańskim wyznaniu, to z pewnością oznaczałoby to jego okaleczenie i niepełność. Oczywiście zasięg i intensywność nabożeństwa do Maryi w poszczególnych konfesjach niech będzie odmienny. Nie wolno ulegać fałszywym wizjom ruchu ekumenicznego, w których jedność chrześcijan sprowadza się do uproszczonych wersji unionizmu, a odrzuca się zdecydowanie pojednaną różnorodność. Wszyscy chrześcijanie mają prawo nie tylko do miłości Chrystusa, lecz także do miłości Jego Matki ${ }^{28}$.

\subsection{Ekumeniczne rozstaje i zbliżenia}

Oczywiście istnieje problem recepcji uzgodnień dialogów ekumenicznych, którym winny towarzyszyć modlitwa, ofiara, asceza, nawrócenie serca do Chrystusa. Teologowie i hierarchowie mogą zbudować przez uzgodnienia i dialog sztuczny gmach jedności Kościoła, w którym nikt nie zamieszka. Brak recepcji dialogów, brak dialogu modlitwy, dialogu postaw, dialogu czynów może utrudnić osiągnięcie autentycznej jedności Kościoła ${ }^{29}$.

$\mathrm{W}$ ekumeniczne zbliżenie wpisane jest pojednanie. $\mathrm{Z}$ racji Wielkiego Jubileuszu Chrześcijaństwa św. Jan Paweł II definiował pojednanie jako pragnienie przywrócenia utraconej jedności. Pojednanie to pogodzenie się zwaśnionych stron, zgoda kończąca kłótnię, spór. W przypadku doznanej krzywdy zakłada ono również darowanie win. Pojednanie ma bliski związek

${ }^{28}$ Poważnym studium w interesującym nas przedmiocie jest monografia: S. C. Napiórkowski, Spór o Matkę. Mariologia jako problem ekumeniczny, wyd. II, Lublin 2011 (Teologia w Dia$\operatorname{logu}, 12)$.

${ }^{29}$ Por. S. C. Napiórkowski, Ekumenizm jutra, [w:] tenże, Razem dla Chrystusa. Wybór publikacji teologiczno-ekumenicznych, red. S. J. Koza, Lublin 2013, s. 487-489 oraz S. C. Napiórkowski, Problemy, problemy, problemy..., [w:] Razem dla Chrystusa..., dz. cyt., s. 490-513. 
z przebaczeniem, które oznacza całkowite wyzbycie się słusznego gniewu, żalu, urazy do kogoś, odpuszczenie, darowanie komuś winy ${ }^{30}$.

Chrześcijański dialog nie rodzi się z taktyki czy wyrachowania, skrytych dążeń do uniatyzmu bądź utajonego pragnienia, aby inni wyznawcy Jezusa przeszli do Kościoła katolickiego. Autentyczny dialog wypływa z głębokiego szacunku dla tego wszystkiego, co w każdym człowieku zdziałał Duch Boży, który „tchnie tam, gdzie chce” (J 3,8). Biskup Rzymu zawsze podkreślał, że aby zbudować podstawy dialogu, trzeba przełamać bariery związane z nieufnością, przesądami i uprzedzeniami. Trzeba porzucić własne kompleksy i wykonać pracę w celu pozyskania tak intelektualnej wiedzy, jak i duchowej pokory. Należy podjąć takie działania, jakie będą systematycznie niwelować podziały istniejące między poszczególnymi Kościołami chrześcijańskimi. Jedność, jakiej pragnie Bóg, może się urzeczywistnić tylko dzięki powszechnej i mądrej wierności wobec całej treści jednego objawienia. Kompromis w sprawach wiary sprzeciwia się Bogu, który jest Prawdą. W żadnym wypadku nie jest dopuszczalne pojednanie, które miałoby być osiągnięte kosztem prawdy. Soborowa Deklaracja o wolności religijnej Dignitatis humanae uznaje za przejaw ludzkiej godności poszukiwanie prawdy, „zwłaszcza w tym, co odnosi się do Boga i Jego Kościoła” ${ }^{11}$, oraz wierne spełnianie jej wymogów. Tak więc „bycie razem”, które zdradziłoby prawdę, jest sprzeczne z naturą samego Boga i kościelną wiernością.

Fałszywy ekumenizm jest zagrożeniem dla wszystkich chrześcijan. Dlatego wszyscy wierzący w Chrystusa, a zwłaszcza katolicy, winni wystrzegać się taniego kompromisu i powierzchownej (medialnej) ugody w sprawach wiary i moralności. Świadomość tożsamości eklezjalnej, połączonej z odkrywaniem bogactwa własnego Kościoła, jest nieodzownym warunkiem dobrze pojętego ekumenizmu. Wraz z Soborem Watykańskim II Kościół katolicki nieodwołalnie wkroczył na trudną drogę ekumenicznych poszukiwań, wsłuchując się w głos Ducha Świętego, który uczy go odczytywać „znaki czasu”. Doświadczenia, które przeżył w ostatnich latach i które nadal gromadzi, pozwalają mu dziś głębiej zrozumieć własną tożsamość i swoją misję w dziejach zbawienia świata.

Święty Jan Paweł II w dwutysiąclecie narodzin Chrystusa pragnął, aby Jubileusz Syna Bożego stał się również Jubileuszem Matki. Wypada zatem

${ }^{30}$ Por. Jan Paweł II, Przebaczamy i prosimy o przebaczenie. Homilia wygłoszona w Bazylice św. Piotra, 12 marca 2000, „L'Osservatore Romano” 2000 nr 6, wyd. pol. s. 42.

${ }^{31}$ Sobór Watykański II, Deklaracja o wolności religijnej Dignitatis humanae, 1. 
sobie życzyć, aby jednym z owoców Wielkiego Jubileuszu była - obok umocnienia miłości do Chrystusa - także odnowa maryjnej pobożności. Dlatego ówczesny papież w homilii wygłoszonej 24 października 2000 roku na zakończenie xx Międzynarodowego Kongresu Maryjno-Mariologicznego powiedział:

Tak, Maryję należy bardzo kochać i czcić, jednakże jej kult, aby był autentyczny:

- musi mieć mocne oparcie w Piśmie Świętym i w Tradycji, podkreślać wartość liturgii i z niej czerpać niezawodne wskazania dla bardziej spontanicznych form przejawów pobożności ludowej;

- winien wyrażać się przez wysiłek naśladowania Tej, która jest cała święta, na drodze do osobistej doskonałości;

- winien wystrzegać się wszelkich przesądów i płytkiej łatwowierności, należycie interpretując, zgodnie z rozeznaniem Kościoła, nadzwyczajne wydarzenia, przez które Najświętsza Panna nierzadko się objawia dla dobra Ludu Bożego;

- musi prowadzić zawsze do źródła wielkości Maryi, stając się nieustannym Magnificat, hymnem uwielbienia Ojca, Syna i Ducha Świętego ${ }^{32}$.

${ }^{32}$ Por. A. A. Napiórkowski, Jedność konsekrowana, dz. cyt., s. 92-93. 


\section{Podsumowanie}

Analizując retrospektywnie książkę Maryja jest piękna. Zarys mariologii i maryjności, nietrudno dostrzec jej braki, co należy uczciwie i pokornie wyznać. Można się wspomóc myślą św. Bernarda, który zauważył, że „nie wystarczyłoby dziewictwo Maryi, gdyby nie Jej pokora”. Dlatego nieśmiało wyznaję, iż należało potraktować szerzej choćby takie zagadnienia, jak: Maryja w relacji do Boga Ojca, Maryja w świetle ówczesnego społeczeństwa żydowskiego i jego religijności, rodzina nazaretańska (relacje między Maryją, Józefem i Jezusem). Także treść rozdziału viI, gdzie jest mowa o celebracji Maryi w Kościele, nie jest wyczerpująca. Te opuszczenia wielu merytorycznych kwestii pojawiły się jednak nie zawsze z powodu ograniczeń autora, ale czasami też i z powodu wymogów, które narzuca charakter podręcznika. Nie chodzi w nim bowiem o prezentację całej aktualnej wiedzy o Matce Jezusa i wszystkich formach Jej czci, ale o ukazanie z jednej strony podstaw tej części teologii systematycznej, a z drugiej oficjalnego nauczania Kościoła na ten temat. Nie było zatem moim zamierzeniem przywoływanie opinii czy tez różnych teologów, lecz przedstawienie obowiązującej i zasadniczej doktryny w tym zakresie.

Według pierwotnych założeń niniejsza publikacja, mimo wymuszonej zgody na pewne zawężenia merytoryczne, została ujęta w taką strukturę, która gwarantowałaby spójność tematyki. Dlatego rozdział pierwszy nosi tytuł Ku integralnej mariologii i zawiera następujące punkty: Kim jest $\mathrm{Ma}$ ryja?, Kontekst wspótczesny, Historia rozwoju mariologii, Mariologia jako traktat dogmatyczny, Źródła mariologii.

Z kolei rozdział drugi, Pismo Święte o Maryi, ukazuje miejsca Starego i Nowego Testamentu, które typicznie bądź bezpośrednio odnoszą się do Najświętszej Maryi Panny. 
Rozdział trzeci koncentruje uwagę na dziejach maryjnej teologii duchowości. Jego treść tworzą punkty: Pisarze apostolscy i apologeci, Ojcowie Kościoła o Matce Bożej, Maryja w teologii średniowiecza, Reformacja: ancilla Domini, Kultura baroku: Maryja w glorii, Oświecenie: racjonalizacja maryjnej pobożności?, XIX i XX wiek: „Uprzywilejowana”, Sobór Watykański II: Maryja chrysto- i eklezjotypiczna, W kierunku mariologii integralnej $i$ interdyscyplinarnej.

Kolejny rozdział, Maryjne prawdy, omawia pięć podstawowych prawd wiary dotyczących Najświętszej Maryi Panny: Matka Boga, Zawsze Dziewica, Wolna od grzechu i święta, Niepokalanie Poczęta, Wniebowzięta.

Pewną nowość w stosunku do wielu podręczników mariologii niesie ze sobą rozdział piąty, Jedność Maryi z Duchem Świętym, gdzie znajdujemy takie punkty, jak: Biblijne przesłanki: Maryja i Duch Święty, Jedność Maryi z Duchem Trójjedynego Boga, Formy i sposoby jedności Maryi z Duchem Boga.

Na zawartość rozdziału szóstego, Maryja w dziele odkupienia, oprócz wielu pomniejszych zagadnień składają się cztery zasadnicze punkty: Wspótdziałanie, Pośrednictwo, Macierzyństwo duchowe, Maryja a Kościół.

Rozdział siódmy, Celebracja Maryi w Kościele, jest dosyć rozbudowany. Wymieńmy jednak jego dziesięć głównych punktów: $Z$ dziejów maryjnej pobożności, Dlaczego należy czcić Maryję?, Teologia kultu Maryi, Odnowa kultu maryjnego w świetle Marialis cultus, Liturgiczne miejsca i sposoby kultu, Modlitewne formy czci, Przepowiadanie (homilie, kazania, katechezy), Maryjne sanktuaria i pielgrzymowanie, Kultura i sztuka o Maryi, Struktury naukowe.

Rozdział przedostatni zapoznaje nas z artyzmem i transcendencją maryjnych obrazów. Jest w nim mowa o Maryi i Jej pięknie w ewangelizacji, o rzekomym zakazie sporządzania ikon w Biblii, o historii teologii ikony, o wcieleniu jako chrystologicznym fundamencie maryjnej ikony oraz o typach ikon maryjnych.

Ostatni rozdział to zarys mariologii ekumenicznej. W skład tego rozdziału wchodzą takie zagadnienia, jak: Prawosławie i Przebłogosławiona, Ewangelicy a Matka Pana, Współczesny dialog chrześcijan oraz Ekumeniczne rozstaje i zbliżenia.

Ten pobieżny przegląd treści niniejszej publikacji, który wskazują powyższe tytuły rozdziałów i krótka charakterystyka ich zawartości, uświadamia bogactwo katolickiej nauki o Najświętszej Maryi Pannie i sposobach oddawania Jej czci. Mariologia i maryjność mają przed sobą wielkie perspektywy 
i możliwości rozwoju. Trzeba pamiętać, że Maryja i Jej życie wciąż pozostają dla nas pewną tajemnicą. Chodzi ostatecznie o mysterium salutis.

Najpełniejszy dostęp do Maryi zyskujemy w Kościele, gdyż ta właśnie bosko-ludzka rzeczywistość gwarantuje tak duchowy, jak i intelektualny wymiar naszego poznania. $\mathrm{W}$ tej przestrzeni jesteśmy zabezpieczeni zarówno przed fideizmem, jak i czystym racjonalizmem. Teologia, która zgłębia treści objawienia, pomaga odkrywać integralną prawdę i strzeże nas z jednej strony przed „przesadną” maryjnością, z drugiej zaś przed pomijaniem obecności Maryi w dziejach zbawienia. Rozwój mariologii i maryjnego kultu - jak zauważył w 1955 roku Pierre Teilhard de Chardin w swoim liście do Maryse Choisy - „odpowiada chrześcijańskiej potrzebie nie do odparcia" i ułatwia usuwanie "straszliwie umęskowionego" obrazu $\mathrm{Boga}^{1}$. Autentyczna mariologia strzeże teologię przed nadmierną spekulatywnością, a Kościół przed skostnieniem i nadmierną instytucjonalizacją.

Wielu teologów słusznie zadaje sobie pytanie: czy jest w ogóle do pomyślenia, aby zaistniał jakiś odpowiednik między nieskończonym Bogiem a skończonym stworzeniem? Jak to jest możliwe, aby nieogarniony Bóg wszedł w zwyczajną ziemską rzeczywistość i przyjął ją za swoją? Oczywiście $\mathrm{z}$ tymi pytaniami wchodzimy $\mathrm{w}$ tajemnicę wcielenia i osoby Jezusa z Nazaretu, który okazuje się odwiecznym Synem Bożym, przyjmującym ludzką naturę. To jednak wciąż nas tak bardzo przerasta!

Dla mnie samego jednak, po wielu latach zgłębiania chrystologii fundamentalnej i eklezjologii, stało się oczywiste, że do tych kwestii w sposób najbardziej odpowiedzialny i bezpieczny można podejść jedynie przez pogłębioną refleksję mariologiczną. Nie ma bowiem Jezusa ani Jego Kościoła bez Maryi. Przez mariologię przebiegają prawie wszystkie teologiczne ścieżki: antropologiczna, chrystologiczna, eklezjologiczna, charytologiczna i eschatologiczna.

Teologia bez modlitwy jest martwa. A zauważmy, że łatwiej do Maryi i z Nią się modlić niż o Niej spekulować. Przez przywilej niepokalanego poczęcia jest Ona najpiękniejszą teologią! Hans Urs von Balthasar, inspirowany maryjnymi objawieniami wielkiej mistyczki Adrienne von Speyr, nie bez powodu wzywał do teologii modlitwy (eine betende und kniende Theologie), odkrywając coraz bardziej obecność i działanie Maryi w życiu Kościoła. W Maryi bowiem płynie najbardziej ożywczy nurt zbawienia,

\footnotetext{
1 Cytat za H. de Lubac, Kommentar, [w:] P. Teilhard de Chardin, Hymne an das Ewig-Weibliche, Einsiedeln 1968, s. 156.
} 
jaki prowadzi do Chrystusa. Dlatego przeniknięcie i rozeznanie własnego człowieczeństwa odbywa się najpełniej z Maryją, też tylko człowiekiem. Ona uczy nas łaknienia Boga, tego prawdziwego Boga, który ,tak umiłował świat, że Syna swego Jednorodzonego dał, aby każdy, kto w Niego wierzy, nie zginął, ale miał życie wieczne. Albowiem Bóg nie posłał swego Syna na świat po to, aby świat potępił, ale po to, by świat został przez Niego zbawiony" $(\mathrm{J} 3,16)$. A kimże jest Jezus Chrystus? On jest nikim innym, jak tylko „Bogiem w Maryi”. 


\section{Wykaz skrótów}

AAS "Acta Apostolicae Sedis”, Roma 1909-

BF Breviarium fidei. Wybór doktrynalnych wypowiedzi Kościoła, oprac. S. Głowa, I. Bieda, Poznań 1988

DCE Benedykt Xvi, Encyklika Deus caritas est o miłości chrześcijańskiej, Watykan, 25 grudnia 2005

Ds. H. Denzinger, A. Schönmetzer, Enchiridion symbolorum, definitionum et declarationum de rebus fidei et morum, 36. Aufl., Barcelona - Freiburg im Br. - Rom 1976

DSP I Dokumenty Soborów Powszechnych, tekst grecki, łaciński, polski, t. I, oprac. A. Baron, H. Pietras, Kraków 2001

EK Encyklopedia katolicka, pod red. F. Gryglewicza, R. Łukaszyka, Z. Sułowskiego, Lublin 1973-

KK Sobór Watykański II, Konstytucja dogmatyczna o Kościele Lumen gentium, Watykan, 21 listopada 1964

KKK Katechizm Kościoła katolickiego, Poznań 1994

KL Sobór Watykański II, Konstytucja dogmatyczna o liturgii Sacrosanctum concilium, Watykan, 4 grudnia 1963

MC Paweł vi, Adhortacja Marialis cultus o należytym kształtowaniu i rozwijaniu kultu Najświętszej Maryi Panny, Watykan, 2 lutego 1974

NMI Jan Paweł II, List apostolski Novo millennio ineunte do biskupów, duchowieństwa i wiernychna zakończenie Wielkiego Jubileuszu Roku 2000, Watykan, 6 stycznia 2001

RM Jan Paweł II, Encyklika Redemptoris Mater o błogosławionej Maryi Dziewicy w życiu pielgrzymującego Kościoła, Watykan, 25 marca 1987

RVM Jan Paweł II, List apostolski Rosarium Virginis Mariae do biskupów, duchowieństwa i wiernych o różańcu świętym, Watykan, 16 października 2002

SM „Salvatoris Mater. Kwartalnik Mariologiczny”, Licheń Stary 1999- 


\section{Bibliografia}

Adamiak E., O co chodzi w teologii feministycznej?, „Więź” 1993 nr 1, s. 68-77.

Adamiak E., Traktat o Maryi, Warszawa 2006 (Dogmatyka, 2).

Amato A., Maryja w walce z szatanem we współczesnym świecie [brak inf. o tłum.], „Salvatoris Mater. Kwartalnik Mariologiczny” 13 (2011) nr 1-2, s. 62-80.

Auer J., Kleines Dogmatik, Bd. 4/2, Jesus Christus - Heiland der Welt. Maria - Christi Mutter im Heilsplan Gottes. Regensburg 1988.

Bartosik G., Mediatrix in Spiritu Mediatore. Pośrednictwo Najświętszej Maryi Panny jako uczestnictwo w pośredniczącej funkcji Ducha Świętego w świetle teologii współczesnej, Niepokalanów 2006 (Biblioteka Mariologiczna).

Bartosik G., Myśl maryjna św. Maksymiliana Marii Kolbego, [w:] „Złota nič” niepokalanego poczęcia w myśli i w życiu bt. Jana Dunsa Szkota i św. Maksymiliana Marii Kolbego, red. nauk. G. M. Bartosik, P. Warchoł, Niepokalanów 2015, s. 205-234 (Bibliotheca Kolbiana. Monografie, 1).

Bator Z., Macierzyństwo duchowe Maryi w chrześcijańskiej ikonografi na podstawie wybranych przykładów, „Salvatoris Mater. Kwartalnik Mariologiczny” 13 (2011) nr 3-4, s. 130-155.

Bator Z., Problem piękna w nowożytnych wizerunkach maryjnych, „Salvatoris Mater. Kwartalnik Mariologiczny" 13 (2011) nr 3-4, s. 255-282.

Benedykt xvi, Encyklika Deus caritas est o miłości chrześcijańskiej, Watykan 2005. Benedykt xvi, Encyklika Caritas in veritate o integralnym rozwoju ludzkim w miłości i prawdzie, Watykan 2009.

Błaszczyszyn J., Maryja w prawosławiu, „Nurt svd. Kwartalnik Misjologiczno-Religioznawczy” 28 (1994) nr 4, s. 53-61.

Bibliografia katechetyczna 1945-1995, oprac. R. Murawski, przy współpr. R. Czekalskiego i J. Tochmańskiego, Warszawa 1999.

Bibliografia katechetyczna 1996-20oo, oprac. R. Czekalski, R. Murawski, Warszawa 2002.

Bokwa I., Wprowadzenie do teologii Karla Rahnera, Tarnów 1996.

Bolewski J., Misterium Mądrości. Traktat sofio-mariologiczny, Kraków 2012 (Myśl Teologiczna, 70).

Buczek J., Bóg Ojciec a Maryja w pieśniach zamieszczonych w „Śpiewniku kościelnym” ks. Jana Siedleckiego, „Salvatoris Mater. Kwartalnik Mariologiczny” 1 (1999) nr 3, s. 81-104. 
Budzik S., Maryja w tajemnicy Chrystusa i Kościoła, wyd. II, Tarnów 1997 (Academica. Instytut Teologiczny w Tarnowie, 9).

Chmielewski M., Implikacje posoborowej mariologii dla duchowości katolickiej w Polsce, „Salvatoris Mater. Kwartalnik Mariologiczny” 16 (2014) nr 1-4, s. 154-170.

Chmielewski M., Maryjny wymiar duchowości katolickiej. Wybór czy konieczność?, „Salvatoris Mater. Kwartalnik Mariologiczny” 12 (2010) nr 1-2, s. 11-23.

Collectio Missarum de Beata Maria Virgine, Città del Vaticano 1987.

Congar Y., Je crois en l'Esprit Saint, 3 vols, Paris 1979-1980.

Congregazione per il Culto Divino e la Disciplina Dei Sacramenti, Direttorio su pietà popolare e liturgia. Principi e orientamenti, Città del Vaticano 2002.

Courth F., Mariologia. Maryja, Matka Chrystusa., tłum. W. Szymona, [w:] Podręcznik teologii dogmatycznej [traktat 6-7], red. nauk. i wprow. do pol. wyd. Z. Kijas. Kraków 1999.

Courth F., Marianische Gebetsformen, [w:] Handbuch der Marienkunde, Bd. I, Hrsg. W. Beinert, H. Petri, Regensburg 1996, s. 526-566.

Czajkowski M., Maryja (2, 1-11; 19, 25-27), [w:] Egzegeza Ewangelii św. Jana. Kluczowe teksty $i$ tematy teologiczne, red. F. Gryglewicz, wyd. 2 popr. i rozszerz., Lublin 1992, s. 11-109.

Częsz B., Maryja w nauczaniu św. Ireneusza z Lyonu, „Salvatoris Mater. Kwartalnik Mariologiczny" 11 (2009) nr 2, s. 70-85.

Cox H., Verführung des Geistes, Stuttgart-Berlin 1974.

Dąbek T. M., Bóg Ojciec i Maryja wobec Jezusa według J 2, 5 i Mt 17, 5, „Salvatoris Mater. Kwartalnik Mariologiczny" 1 (1999) nr 2, s. 167-178.

Dobrzyński A., Matka w wierze: duchowe macierzyństwo Maryi w nauczaniu bł. Jana Pawła II, „Salvatoris Mater. Kwartalnik Mariologiczny” 13 (2011) nr 3-4, s. 200-238.

Ferdek B., Dialog o Matce Pana w kontekście różańca, „Salvatoris Mater. Kwartalnik Mariologiczny" 5 (2003) nr 1, s. 220-232.

Ferdek B., Duch Boży nad wodami Renu. Refleksje nad ścieżkami nadreńskiej pneumatologii, Wrocław 2010.

Ferdek B., Maryja w tajemnicy Zmartwychwstania Chrystusa, „Salvatoris Mater. Kwartalnik Mariologiczny" 14 (2012) nr 1-4, s. 21-34.

Ferdek B., Objawienia maryjne a znaki czasów, „Salvatoris Mater. Kwartalnik Mariologiczny" 11 (2009) nr 1, s. 47-57.

Fiores S., De, Maria e il mistero del male, a cura di S. M. Perrella, Milano 2013.

Fiores S., De, Maria in der Geschichte von Theologie und Frömmigkeit, [w:] Handbuch der Marienkunde, Bd. I, Hrsg. W. Beinert, H. Petri, Regensburg 1996, s. 99266. 
Fiores S., De, Maria. Madre di Gesù. Sintesi stolico-salvifica, Bologna 1998.

Fiores S., De, Maria nel dialogo ecumenico post-conciliare, [w:] tenże, Maria nella teologia contemporanea, Roma 1987, s. 230-255.

Fiores S., De, Mariologia w wymiarze estetycznym [brak inf. o tłum.], „Salvatoris Mater. Kwartalnik Mariologiczny" 11 (2009) nr 2, s. 161-192.

Flanagan D., Eschatologia a wniebowzięcie, tłum. z ang. S. Napiórkowski, „Concilium. Międzynarodowy Przegląd Teologiczny” 1969 nr 1, s. 76-84.

Florenski P., Ikonostas i inne szkice, przeł. Z. Podgórzec, Białystok 1997 (Kościół Wschodni).

Florkowski E., Matka Boża w nauce ojców Kościoła, [w:] Gratia plena. Studia teologiczne o Bogurodzicy, pod red. B. Przybylskiego, Poznań 1965, s. 59-79.

Forte B., Maryja, ikona tajemnicy. Zarys mariologii symboliczno-narracyjnej, przeł. B. Widła, Warszawa 1999 (Theotokos, 8).

Frejlich A., Ikona, [w:] Encyklopedia katolicka, pod red. F. Gryglewicza, R. Łukaszyka, Z. Sułowskiego, t. 7, Lublin 1997, k. 9-10.

Greshake G., Maria - Ecclesia. Perspektiven einer marianisch grundierten Theologie und Kirchenpraxis, Regensburg 2014.

Gros J., Mariologia luterańska, [w:] Nosicielka Ducha, Pneumatofora. Materiały z Kongresu Mariologicznego, Jasna Góra, 18-23 sierpnia 1996 r., red. J. Wojtkowski, S. C. Napiórkowski, Lublin 1998, s. 101-111.

Guitton J., Dialogi z Pawłem vi, tłum. L. Rutowska, Poznań-Warszawa 1969.

Gumppenberg W., Atlas Marianus, sive De imaginibus Deiparae per orbem Christianum miraculosis, Ingolstadt 1657, www.reader.digitale-sammlungen.de/en/ fs1/object/display/bsb11093001_oooo4.html (29.07.2016).

Guzowski K., Duch dialogujący. Zarys pneumatologii dialogalnej, Lublin 2016.

Guzowski K., Maryja a Trójca Święta. Personologia trynitarna fundamentem odnowy mariologii współczesnej, „Salvatoris Mater. Kwartalnik Mariologiczny” 16 (2014) nr 1-4, s. 11-26.

Haręzga S., Małżeństwo Maryi i Józefa, „Salvatoris Mater. Kwartalnik Mariologiczny" 11 (2009) nr 3, s. 11-20.

Jabłoński Z. J., Recepcja nauki mariologicznej Soboru Watykańskiego II w polskich sanktuariach, „Salvatoris Mater. Kwartalnik Mariologiczny” 16 (2014) nr 1-4, s. 211-265.

Jak czcić Matkę Bożą? Adhortacja apostolska papieża Pawła VI „Marialis cultus” o należytym kształtowaniu i rozwijaniu kultu Najświętszej Maryi Panny, pr. zbior., przygot. do wyd. i wstęp S. C. Napiórkowski, Niepokalanów 1984.

Jan Paweł II, Encyklika Evangelium vitae o wartości i nienaruszalności życia ludzkiego, Watykan 1995. 
Jan Paweł II, Encyklika Redemptoris Mater o błogosławionej Maryi Dziewicy w życiu pielgrzymującego Kościoła, Watykan 1987.

Jan Paweł II, List apostolski o godności kobiety Mulieris dignitatem, Watykan 1988. Jan Paweł II, List apostolski Rosarium Virginis Mariae do biskupów, duchowieństwa i wiernych o różańcu świętym, Watykan 2002.

Jan Paweł II, Pierwsza Pielgrzymka do Polski. Homilia wygłoszona pod szczytem Jasnej Góry, 4.06.1979.

Jan Paweł II, Przebaczamy i prosimy o przebaczenie. Homilia wygłoszona w Bazylice św. Piotra, 12 marca 200o, „L'Osservatore Romano” 2000 nr 6, wyd. pol., s. 42. Jan Paweł II, Rozważanie przed modlitwa „Anioł Pański” [przemówienie wygłoszone we Wrocławiu podczas pielgrzymki do Ojczyzny w 1997 roku], 1.06.1997.

Jezierski J., Maryja początkiem nowego świata. Zarys mariologii katolickiej, Olsztyn 2011. Jilek A., Marienmessen und Marienvespern, [w:] Handbuch der Marienkunde, Bd. I, Hrsg. W. Beinert, H. Petri, Regensburg 1996, s. 504-525.

Kasjaniuk E., Maryja, [w:] Encyklopedia katolicka, pod red. F. Gryglewicza, R. Łukaszyka, Z. Sułowskiego, t. 12, Lublin 2008, k. 1.

Kiciński J., Maryja wzorem duchowości ubogich (wokół ślubu ubóswa), „Salvatoris Mater. Kwartalnik Mariologiczny” 17 (2015) nr 1-4, s. 49-6o.

Kijas Z. J., Analiza prawosławnej mariologii na podstawie lektury trzech ważnych tekstów, „Polonia Sacra” 2002 nr 11, s. 21-38.

Kijas Z. J., Maryja w tajemnicy wcielenia w świetle antropologii trynitarnej Pawła Florenskiego, „Salvatoris Mater. Kwartalnik Mariologiczny” 2 (2000) nr 1, S. 132-155.

Kleinheyer B., Maria in der Liturgie, [w:] Handbuch der Marienkunde, Bd. I, Hrsg. W. Beinert, H. Petri, Regensburg 1996, s. 469-476.

Klinger J., Zarys prawosławnej mariologii, [w:] tenże, O istocie prawosławia. Wybór pism, Warszawa 1983, s. 209-247.

Kniazeff A., Matka Boża w Kościele prawosławnym, przeł. H. Paprocki, Warszawa 1996 (Theotokos, 7).

Knoch O., Maria in der Heiligen Schrift, [w:] Handbuch der Marienkunde, Bd. I, Hrsg. W. Beinert, H. Petri, Regensburg 1984, s. 15-92.

Kochaniewicz B., Wschodnie $i$ zachodnie elementy teologii ikony w pismach Jana Pawła II, [w:] Dziedzictwo chrześcijańskiego Wschodu i Zachodu - między pamięcia a oczekiwaniem, red. J. Grabowski, U. Cierniak, Częstochowa 2006, s. 267-278 (Człowiek, Wiara, Kultura, 2).

Kongregacja Nauki Wiary, Instrukcja o chrześcijańskiej wolności i wyzwoleniu Liberatis conscientia (1986), [w:] W trosce o pełnię wiary. Dokumenty Kongregacji Nauki Wiary 1966-1994, tłum. i oprac. Z. Zimowski, J. Królikowski, Tarnów 1995, s. 244-282. 
Kongregacja Nauki Wiary, List do Biskupów o niektórych zagadnieniach dotyczących eschatologii, [w:] W trosce o petnię wiary. Dokumenty Kongregacji Nauki Wiary 1966-1994, tłum. i oprac. Z. Zimowski, J. Królikowski, Tarnów 1995, s. 129-132.

Kongregacja Wychowania Katolickiego, List Maryja Dziewica w formacji intelektualnej i duchowej adresowany do rektorów Seminariów Diecezjalnych i przewodniczacych Wydziałów Teologicznych, 25.03.1988.

Kowalik K., Wejrzał na nicość swojej służebnicy. Teologiczno-ekumeniczne studium Komentarza Dr. Lutra do Magnificat, Lublin 1995 (Jeden Pan, Jedna Wiara).

Kraszewski Z. J., Mariologia, Paris 1964.

Królikowski J., Piękno manifestacją świętości Maryi, „Salvatoris Mater. Kwartalnik Mariologiczny" 15 (2013) nr 1-4, s. 62-77.

Królikowski J., Kupiec K., Matka Zbawiciela. Mariologia, cz. II, Tarnów 2000.

Kudasiewicz, J., Matka Odkupiciela, Kielce 1991 (Maryja w Dziejach Zbawienia, 1).

Kudasiewicz J., Maryja w Biblii. Obraz Maryi w ujęciu synoptyków, [w:] Encyklopedia katolicka, pod red. F. Gryglewicza, R. Łukaszyka, Z. Sułowskiego, t. 12, Lublin 2008, k. 1-11.

Kudasiewicz J., Odkrywanie Ducha Świętego. Medytacje biblijne, Kielce 1998.

Kudasiewicz J., Witczyk H., Kontemplacja Chrystusa - Ikony miłosiernego Ojca. Medytacje biblijno-kerygmatyczne, Kielce 2002 (Biblioteka Współczesnej Ambony, 3).

Kumala J., Fenomen zjawień maryjnych $w$ przestrzeni pobożności ludowej, „Salvatoris Mater. Kwartalnik Mariologiczny" 11 (2009) nr 1, s. 59-74.

Kumala J., Maryja eschatologiczna ikona Kościoła, [w:] Matka Jezusa pośród pielgrzymującego Kościoła, red. J. S. Gajek, K. Pek, Warszawa 1993, s. 19-36 (Theotokos, 4).

Kumala J., Maryja w życiu i duchowości bł. Jerzego Matulaitisa-Matulewicza (18711927), „Salvatoris Mater. Kwartalnik Mariologiczny” 12 (2010) nr 3-4, s. 216-226.

Kumala J., Znaczenie sanktuarium maryjnego dla pobożności ludowej, [w:] Maryjne orędzie z Gietrzwałdu. Materiały z sympozjum mariologicznego Gietrzwałd, 13-15 września 2002 roku, red. J. Jezierski, K. Brzozowski, T. Siudy, Częstochowa-Gietrzwałd 2003, s. 129-145 (Biblioteka Mariologiczna, 3).

Larentzakis G., Die orthodoxe Kirche. Ihr Leben und ihr Glaube, Graz-Wien-Köln 2000.

Laurentin R., Matka Pana. Krótki traktat teologii maryjnej, z fr. przeł. Z. Proczek, słowo wstępne S. C. Napiórkowski, Warszawa 1989 (Theotokos, 1).

Laurentin R., Matka Pana. Traktat mariologiczny, przeł. R. Siemieńska, Częstochowa 1989.

Laurentin R., Struktur und Theologie der lukanischen Kindheitsgeschichte, Stuttgart 1967. 
Lekan J., Chrystologiczny wymiar „via pulchritudinis” w mariologii, „Salvatoris Mater. Kwartalnik Mariologiczny" 15 (2013) nr 1-4, s. 31-47.

Leśniewski K., „Kim jest człowiek, że o nim pamiętasz...?” Podstawowe idee współczesnej antropologii prawosławnej, Lublin 2015 (Światło Przemienienia, 8).

Lexikon für Theologie und Kirche. Das Zweite Vatikanische Konzil. Konstitutionen, Dekrete und Erklärungen, Bd. viI, Freiburg im Br. 1962.

Listy Pasterskie Episkopatu Polski 1945-20oo, t. I-II, red. P. Libera, A. Rybicki, S. Łącki, Marki 2003.

Lubac de, H., Kommentar, [w:] P. Teilhard de Chardin, Hymne an das Ewig-Weibliche, Einsiedeln 1968, s. 17-160.

Luter M., Komentarz do Magnificat, [w:] Teksty o Matce Bożej. Chrześcijaństwo ewangelickie, wstęp, wybór i oprac. S. C. Napiórkowski, przeł. E. Adamik i in, Niepokalanów 2000, s. 129-136 (Beatam Me Dicent, 10).

Łaszewski W., Dziewicze macierzyństwo Maryi - znak miłości transcendującej świat w świetle teologii Karla Rahnera, „Salvatoris Mater. Kwartalnik Mariologiczny” 2 (2000) nr 1, s. 103-119.

Łukaszuk T. D., Ikona $w \dot{z} y$ ciu, $w$ wierze i w teologii Kościoła, Kraków 2008.

Łukaszuk T. D., Obraz święty - ikona w życiu, w wierze i w teologii Kościoła, Częstochowa 1993.

Łukaszuk T. D., Wcielenie fundamentem ikony, [w:] Ikona liturgiczna. Ewangelizacyjne przesłanie ikonografii maryjnej, red. K. Pek, Warszawa 1999, s. 25-39 (Theotokos, 9).

Maria nella comunità ecumenica, a cura di Segretariato Attività Ecumeniche, Roma 1982.

Maron G., Maria nella teologia protestante, „Concilium. Rivista Internazionale di Teologia” 19 (1983), s. 92-105.

Mastalska D., Jaka duchowość maryjna dla kobiet?, „Salvatoris Mater. Kwartalnik Mariologiczny" 12 (2010) nr 1-2, s. 122-168.

Mastalska D., Maryja rozmiłowana w Ojcu, „Salvatoris Mater. Kwartalnik Mariologiczny" 1 (1999) nr 4, s. 11-29.

Mastalska D., Maryja w tajemnicy zbawienia, Licheń Stary 2012.

Matka Teresa z Kalkuty, brat Roger z Taizé, Maryja, Matka Pojednania, tłum. z fr. M. Adamczyk, Katowice 1988.

Maximos (Aghiorgoussis), Wiara Kościoła, [w:] Prawosławie. Światło ze wschodu, red. K. Leśniewski, Lublin 2009, s. 29-48.

McHugh J., Maryja w Nowym Testamencie, przeł. A. Czarnocki, Niepokalanów 1998. Melotti L., Maryja i jej misja macierzyńska. Zarys teologii maryjnej, przeł. T. Siudy, Kraków 1983. 
Missale Romanum, editio typica, Città del Vaticano 1970.

Miziołek W., Kult Matki Bożej, [w:] Gratia plena. Studia teologiczne o Bogurodzicy, pod red. B. Przybylskiego, Poznań 1965, s. 429-442.

Moga I., Hans Urs von Balthasar, [w:] Zeitgenössische Kirchenverständnisse. Acht ekklesiologische Porträts, Hrsg. C. Keppler, J. C. Pech, Heiligenkreuz 2013, s. 26-58.

Mroczkowski I., Ikonolatria, [w:] Encyklopedia katolicka, pod red. F. Gryglewicza, R. Łukaszyka, Z. Sułowskiego, t. 7, Lublin 1997, k. 14-15.

Mulack C., Maria. Die geheime Göttin im Christentum, Stuttgart 1985.

Napiórkowski A. A., Bogactwo łaski a nędza grzesznika. Zróżnicowany konsensus teologii katolickiej i luterańskiej o usprawiedliwianiu osiagnięty w dialogu ekumenicznym, Kraków 2011.

Napiórkowski A. A., Bosko-ludzka wspólnota. Podstawy katolickiej eklezjologii integralnej, Kraków 2010 (Myśl Teologiczna, 65).

Napiórkowski A. A., Ekumeniczna rola Jasnej Góry, [w:] Jasna Góra w dwudziestoleciu pontyfikatu Jana Pawła II, red. Z. S. Jabłoński, Częstochowa 1999, s. 379-392. Napiórkowski A. A., Jedność konsekrowana, Kraków 2002 (Collectio ViCo, 3).

Napiórkowski, A. A., Jezus Chrystus Objawiony i Objawiający. Chrystologia fundamentalna, wyd. 2, Kraków 2016 (Myśł Teologiczna, 61).

Napiórkowski A. A., Mariologia $w$ dialogu katolicko-protestanckim, „Salvatoris Mater. Kwartalnik Mariologiczny” 3 (2001) nr 4, s. 91-111.

Napiórkowski A. A., Pośrednictwo Maryi w maryjnym dokumencie Grupy z Dombes, „Salvatoris Mater. Kwartalnik Mariologiczny” 4 (2002) nr 3 (15), s. 217-231. Napiórkowski A. A., Schrift, Tradition, Kirche. Glaubensquelle in Matthias Joseph Scheebens theologischer Erkenntnislehre, Frankfurt am Main 1996.

Napiórkowski A. A., Teologie Xx i XxI wieku, Kraków 2016.

Napiórkowski A. A., Wniebowzięta umacnia wiare w eschatyczne powołanie Kościoła, [w:] Jasnogórska Szkoła Wiary. Ogólnopolskie Sympozjum Mariologiczno-Maryjne, Jasna Góra, 10 kwietnia 2013, red. Z. S. Jabłoński, Częstochowa 2013, s. 83-98.

Napiórkowski S. C., Ecumenismo, [w:] Nuovo Dizionario di Mariologia, a cura di S. De Fiores, Milano 1985, s. 518-527.

Napiórkowski S. C., Ekumenizm jutra, [w:] tenże, Razem dla Chrystusa. Wybór publikacji teologiczno-ekumenicznych, red. S. J. Koza, Lublin 2013, s. 487-489.

Napiórkowski S. C., Jak uprawiać teologie,, Wrocław 1994.

Napiórkowski S. C., Maria w ewangelicyzmie, [w:] Religia. Encyklopedia PwN, t. vi, red. T. Gadacz, B. Milerski, Warszawa 2002.

Napiórkowski S. C., Mariologia, [w:] Encyklopedia katolicka, pod red. F. Gryglewicza, R. Łukaszyka, Z. Sułowskiego, t. 11, Lublin 2006, k. 1371-1379. 
Napiórkowski S. C., Maryja w duchowości, [w:] Encyklopedia katolicka, pod red. F. Gryglewicza, R. Łukaszyka, Z. Sułowskiego, t. 12, Lublin 20o8, k. 27-33.

Napiórkowski S. C., Maryja w teologii, [w:] Encyklopedia katolicka, pod red. F. Gryglewicza, R. Łukaszyka, Z. Sułowskiego, t. 12, Lublin 2008, k. 18-23.

Napiórkowski S. C., Matka naszego Pana (problemy-poszukiwania-perspektywy), Tarnów 1992.

Napiórkowski S. C., Nauczanie papieskie. Maryja w nauczaniu Kościoła, [w:] Encyklopedia katolicka, pod red. F. Gryglewicza, R. Łukaszyka, Z. Sułowskiego, t. 12, Lublin 2008, k. 14-18.

Napiórkowski S. C., Problemy, problemy, problemy..., [w:] tenże, Razem dla Chrystusa. Wybór publikacji teologiczno-ekumenicznych, red. S. J. Koza, Lublin 2013, s. 490-513. Napiórkowski S. C., Sanktuaria maryjne w stużbie pojednania, jedności i pokoju, [w:] Nosicielka Ducha, Pneumatofora. Materiały z Kongresu Mariologicznego, Jasna Góra, 18-23 sierpnia 1996 r., red. J. Wojtkowski, S. C. Napiórkowski, Lublin 1998, s. 371-384.

Napiórkowski S. C., Spór o Matkę. Mariologia jako problem ekumeniczny, wyd. II, Lublin 2011 (Teologia w Dialogu, 12).

Nissiotis N., Maria della teologia ortodossa, „Concilium. Rivista Internazionale di Teologia" 19 (1983), s. 66-91.

Nissiotis N., Maryja w teologii prawosławnej, [w:] Prawosławie. Światło ze wschodu, red. K. Leśniewski, Lublin 2009, s. 79-97.

Olszewski D., Dzieje chrześcijaństwa w zarysie, Kraków 1996.

Orygenes, Przeciw Celsusowi, tłum. S. Kalinkowski, E. Stanula, W. Myszor, Warszawa 1977 (Pisma Starochrześcijańskich Pisarzy, 17, z. 1).

Pach J., Duchowe macierzyństwo Maryi w kerygmie Stefana Kardynała Wyszyńskiego, „Salvatoris Mater. Kwartalnik Mariologiczny” 13 (2011) nr 3-4, s. 186-219.

Pałubska Z., Pod Twoją obronę, [w:] Encyklopedia katolicka, pod red. F. Gryglewicza, R. Łukaszyka, Z. Sułowskiego, t. 15, Lublin 2011, k. 964-965.

Papieska Międzynarodowa Akademia Maryjna, Matka Pana. Pamięć - obecność nadzieja. Niektóre aktualne zagadnienia dotyczace postaci i misji Najświętszej Dziewicy Maryi, „Salvatoris Mater. Kwartalnik Mariologiczny” 5 (2003) nr 3, s. 311-398.

Paweł vi, Adhortacja Marialis cultus o należytym kształtowaniu i rozwijaniu kultu Najświętszej Maryi Panny, Watykan 1974.

Paweł vi, Adhortacja Signum magnum do Biskupów, kapłanów i wiernych całego Katolickiego świata o radości chrześcijańskiej, Watykan 1967.

Paweł vi, Przemówienie na zakończenie III sesji Soboru Watykańskiego II, 21 listopada 1964 roku, [w:] Gratia plena. Studia teologiczne o Bogurodzicy, pod red. B. Przybylskiego, Poznań 1965, s. XviıI. 
Piękno Kościoła, red. M. Chojnacki, J. Morawa, A. Napiórkowski, Kraków 2014.

Pius XII, Encyklika Mediator Dei o Świętej Liturgii, Watykan 1947.

Płatek J., Sprawowanie sakramentu pokuty i pojednania, wyd. 2, Częstochowa 2001.

Popova O., Smirnova E., Cortesi P., Ikony, tłum. T. Łozińska, Warszawa 1998.

Praśkiewicz S., Duchowość maryjna, Kraków 2008 (Vita Consecrata, 29).

Prawosławie. Światło ze Wschodu, red. K. Leśniewski, Lublin 2009.

Przybylski B., Mariologia w całości teologii, [w:] Gratia plena. Studia teologiczne o Bogurodzicy, pod red. B. Przybylskiego, Poznań 1965, s. 7-29.

Ptaszycka-Jackowska D., Jackowski A., Jasnogórskie pielgrzymki w przestrzeni miasta i regionu Częstochowy, Kraków 1998.

Rahner K., Grundkurs des Glaubens, Freiburg-Basel-Wien 1976.

Rahner K., Mariologie, [w:] Lexikon für Theologie und Kirche. Das Zweite Vatikanische Konzil. Konstitutionen, Dekrete und Erklärungen, Bd. viI, Freiburg im Br. 1962, k. 85-86.

Ratzinger J. - Benedykt xvi, Jezus z Nazaretu. Dzieciństwo, przeł. W. Szymona, Kraków 2012.

Ratzinger J., Der Geist der Liturgie. Eine Einführung, Freiburg-Basel-Wien 2000 (wyd. pol.: Duch liturgii, przeł. E. Pieciul, Poznań 2002).

Ratzinger J., „Ty jesteś pełna łaski”. Elementy pobożności maryjnej, „Communio. Międzynarodowy Przegląd Teologiczny” 2000 nr 6 (120), s. 140-143.

Radford-Ruether R., Maria - Kirche in weiblicher Gestalt, München 1980.

Ramirez N. G., Chwalebne wniebowzięcie Maryi, „Communio. Międzynarodowy Przegląd Teologiczny” 2000 nr 6 (120), s. 109-125.

Ritschl D., Überlegungen zur gegenwärtigen Diskussion über Mariologie, „Ökumenische Rundschau” 31 (1982) nr, s. 443-46o.

Rosik M., Biblijna ikona piękna Maryi, „Salvatoris Mater. Kwartalnik Mariologiczny" 15 (2013) nr 1-4, s. 11-22.

Rubinkiewicz R., Czy Bóg zakazał czcić obrazy?, [w:] Ikona liturgiczna. Ewangelizacyjne przesłanie ikonografii maryjnej, red. K. Pek, Warszawa 1999, s. 17-24 (Theotokos, 9).

Rybicki A., Maryja obrazem piękna Kościoła, „Salvatoris Mater. Kwartalnik Mariologiczny" 15 (2013) nr 1-4, s. 78-88.

Ryszka C., Łaska objawień. Barbara Samulowska z Gietrzwałdu, Gietrzwałd 2004. Siudy T., Recepcja myśli soborowej w kulcie maryjnym w Polsce, „Salvatoris Mater. Kwartalnik Mariologiczny" 16 (2014) nr 1-4, s. 171-187.

Siudy T., Źródła i podstawy kultu maryjnego, [w:] Kościót czci Matkę swego Pana. Sympozjum mariologiczne zorganizowane przez Wyższe Seminarium Duchowne 
w Przemyślu w dniu 23 października 2002 r. Materiały, red. W. Siwak, Przemyśl 2003, s. 15-25.

Siwak W., Jaka Maryja dla XXI wieku? Maryja w korelacjach z Bogiem, Kościołem i człowiekiem, „Salvatoris Mater. Kwartalnik Mariologiczny” 11 (2009) nr 4, s. $195-248$.

Siwak W., Ku pośrednictwu w Chrystusie, „Salvatoris Mater. Kwartalnik Mariologiczny" 16 (2014) nr 1-4, s. 37-53.

Siwak W., Maryja w tajemnicy Chrystusa w polskim kulcie maryjnym, [w:] Recepcja „Marialis cultus" w Polsce. Materialy z ogólnopolskiego sympozjum mariologicznego, Licheń, 12-13 marca 2004 roku, red. J. Kumala MIC, Licheń Stary 2004, s. 75-148.

Skowronek A., Słowo wstępne, [w:] M. Thurian, Maryja Matka Pana figura Kościoła, przeł. E. Ogiński, Warszawa 1990, s. 6-8 (Theotokos, 2).

Skowronek A., Zagadnienia maryjne w dialogu ekumenicznym, [w:] Matka Jezusa pośród pielgrzymującego Kościoła, red. J. S. Gajek, K. Pek, Warszawa 1993, s. 370-374 (Theotokos, 4).

Sobór Efeski, Formuła zjednoczenia, [w:] Dokumenty Soborów Powszechnych, tekst grecki, łaciński, polski, t. I, oprac. A. Baron, H. Pietras, Kraków 2001, s. 177-178.

Sobór Konstantynopolitański I, Wyznanie wiary 150 ojców, [w:] Dokumenty Soborów Powszechnych, tekst grecki, łaciński, polski, t. I, oprac. A. Baron, H. Pietras, Kraków 2001, s. 69.

Sobór Nicejski I, Wyznanie wiary 318 ojców, [w:] Dokumenty Soborów Powszechnych, tekst grecki, łaciński, polski, t. I, oprac. A. Baron, H. Pietras, Kraków 2001, s. 25.

Sobór Watykański II. Konstytucje, dekrety, deklaracje. Tekst polski, nowe tłumaczenie, red. M. Przybył, Poznań 2002.

Sobór Watykański II, Konstytucja dogmatyczna o Objawieniu Bożym Dei verbum, Watykan 1965.

Sobór Watykański II, Konstytucja duszpasterska o Kościele w świecie współczesnym Gaudium et spes, Watykan 1965.

Sölle D., Sympathie, Stuttgart 1978.

Speyr A., von, Stużebnica Pańska, przeł. J. Koźbiał, Warszawa 1998.

Spinetoli O., da, Maryja w Biblii, przeł. A. Tronina, Niepokalanów 1997.

Starowieyski M., Maryja w Kościele starożytnym, [w:] Matka Jezusa pośród pielgrzymującego Kościoła, red. J. S. Gajek, K. Pek, Warszawa 1993, s. 77-106 (Theotokos, 4).

Statut Polskiego Towarzystwa Mariologicznego, „Salvatoris Mater. Kwartalnik Mariologiczny" 1 (1999) $\mathrm{nr}$ 2, 460-464.

Suenens L.-J., Kim jest Ona? Synteza Mariologii [brak inf. o tłum.], Warszawa 1988. Ternka K., Maryjne znamię Kościoła w teologii Hansa Ursa von Balthasara, „Salvatoris Mater. Kwartalnik Mariologiczny" 13 (2011) nr 1-2, s. 11-49. 
Thomas de Aquino, Summa theologica (wyd. pol.: Tomasz z Akwinu, Suma teologiczna, tłum. P. Bełch, t. 7, Londyn 1980.

Torrell J.-P., Dziewica Maryja w wierze katolickiej, przeł. M. Szewc-Osiecka, Poznań 2013.

Uspienski L., Teologia ikony, tłum. M. Żurowska, Poznań 1993.

Ut unum sint. Dokumenty Kościoła katolickiego na temat ekumenizmu 1982-1998, red. S. C. Napiórkowski, K. Leśniewski, J. Leśniewska, Lublin 2000.

Valtorta M., Poemat Boga-Człowieka, przeł. E. Bromboszcz, Katowice 1996.

Voss G., Mariologie und Marienverehrung, [w:] Handbuch der Ökumenik, Hrsg. H. J. Urban und H. Wagner, Bd. III/2, Paderborn 1987, s. 251-258.

Wanke J., Maria im vierten Evangelium, [w:] Theologisches Jahrbuch (L), Leipizig 1983 , s. 117-125.

Warchoł P., Maryja inspiracją dla osób konsekrowanych, „Salvatoris Mater. Kwartalnik Mariologiczny" 17 (2015) nr 1-4, s. 61-76.

Warner M., Sola fra le donne. Mito e culto di Maria Vergine, Palermo 1980.

Warzeszak J., Macierzyństwo duchowe Maryi w ujęciu teologów średniowiecznych, „Salvatoris Mater. Kwartalnik Mariologiczny” 13 (2011) nr 3-4, s. 45-64.

Werbiński I., Posłuszeństwo Ojcu droga świętości Maryi, „Salvatoris Mater. Kwartalnik Mariologiczny" 1 (1999) nr 4, s. 30-43.

Werfel F., Pieśn o Bernadetcie, przeł. M. Kłos, Poznań [b.r.].

Witczyk H., Bóg Ojciec a Maryja w tajemnicy zwiastowania, „Salvatoris Mater. Kwartalnik Mariologiczny" 1 (1999) nr 2, s. 113-131.

Wojtczak A., Protestancka tęsknota za Maryją, „Salvatoris Mater. Kwartalnik Mariologiczny" 13 (2011) nr 3-4, s. 359-365.

Wybrane Księgi Symboliczne Kościoła Ewangelicko-Augsburskiego, przeł. A. Wantuła, W. Niemczyk, Warszawa 1980.

Wysocki M., Maryja w pismach Tertuliana, „Salvatoris Mater. Kwartalnik Mariologiczny" 11 (2009) nr 2, s. 109-135.

Ziegenaus A., Maria in der Heilsgeschichte. Mariologie, [w:] Katholische Dogmatik, Bd. v, Hrsg. L. Scheffczyk, A. Ziegenaus, Aachen 1998.

Ziemiański S., Polskie pieśni maryjne, „Posłaniec” 2009, maj, s. 30-31.

Życiński W., Droga Maryi u boku Syna Najwyższego, „Salvatoris Mater. Kwartalnik Mariologiczny" 15 (2013) nr 1-4, s. 303-325.

Życiński W., Historyczne doświadczenie osób i wspólnot chrześcijańskich, [w:] Jan Paweł II, Matka Odkupiciela. Tekst i komentarze, red. S. C. Napiórkowski, Lublin 1993, s. 81-89.

Życiński W., Prawda o Bożym macierzyństwie Maryi. Perspektywa ekumeniczna, „Salvatoris Mater. Kwartalnik Mariologiczny” 2 (2000) nr 1, s. 201-214. 


\section{Spis treści}

I Ku integralnej mariologii . . . . . . . . . . . . . . . . . 5

1.1. Kim jest Maryja? . . . . . . . . . . . . . . . . . . 5

1.1.1. Czas i środowisko Jej życia . . . . . . . . . . . . . . . 6

1.1.2. "Jest piękna” - imię Miriam . . . . . . . . . . . . . . . . . . . . . . . . . . .

1.2. Kontekst współczesny. . . . . . . . . . . . . . . 10

1.2.1. Nowa mariologia . . . . . . . . . . . . . . . . . . . . . . . . . . . . .

1.2.2. Początki teologii feministycznej . . . . . . . . . . . . . . . . . . . . . . . . . . .

1.2.3. Między feminizmem a emancypacją . . . . . . . . . . . . . . . . . . . . . . 15

1.2.4. Dowartościować kobiecość Maryi . . . . . . . . . . . . . . . . . . . . . . . . . .

1.2.5. Pobożność ludowa . . . . . . . . . . . . . . . . . 21

1.2.6. Polska maryjność - fenomen nie tylko Jasnej Góry . . . . . . . 24

1.3. Historia rozwoju mariologii . . . . . . . . . . . . . . 28

1.4. Mariologia jako traktat dogmatyczny . . . . . . . . . . 33

1.5. Źródła mariologii . . . . . . . . . . . . . . . 35

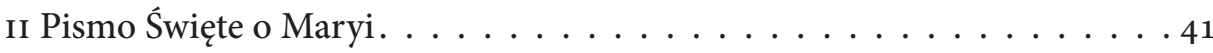

2.1. Teksty typiczne Starego Testamentu . . . . . . . . . . . . . . . . . . . . . . . . . .

2.2. Maryja w świetle Nowego Testamentu . . . . . . . . . . . . . . . . . . . . . . . . . . . . . .

2.2.1. Świadectwo św. Pawła: bezimienna rodząca . . . . . . . . . . . . 46

2.2.2. Ewangelia św. Marka: Maryja w rodzinie ludzkiej i eschatycznej . . 47

2.2.3. Ewangelia św. Mateusza: Maryja w rodowodzie Jezusa . . . . . . . 49

2.2.4. Ewangelia św. Łukasza: Maryja wiary . . . . . . . . . . . . . . 52

2.2.5. Mariologia św. Jana: Matka Jezusa . . . . . . . . . . . . . . . . . . . . . . 69

2.2.6. Apokalipsa: Kościół i Maryja . . . . . . . . . . . . . . . . . 62

2.3. W kierunku biblijnej mariologii i maryjności . . . . . . . . . . . . . . 64

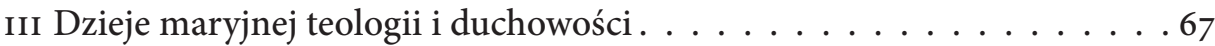

3.1. Pisarze apostolscy i apologeci . . . . . . . . . . . . . . . . . . 69

3.2. Ojcowie Kościoła o Matce Bożej . . . . . . . . . . . . . . 71

3.2.1. Antyteza Ewa - Maryja . . . . . . . . . . . . . . 71

3.2.2. Aeiparthenos - zawsze Dziewica . . . . . . . . . . . . . . . . . . . . . . . . .

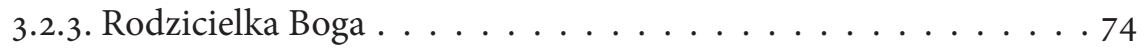

3.2.4. Panhagia. . . . . . . . . . . . . . . 76

3.2.5. Cześć maryjna . . . . . . . . . . . . . . . . . . . . . . . . . . 78

3.3. Maryja w teologii średniowiecza . . . . . . . . . . . . . . 79 
3.4. Reformacja: ancilla Domini. . . . . . . . . . . . . . . 81

3.5. Kultura baroku: Maryja w glorii . . . . . . . . . . . . . . . . . . . 83

3.6. Oświecenie: racjonalizacja maryjnej pobożności? . . . . . . . . . . . 85

3.7. XIX i xx wiek: „Uprzywilejowana”. . . . . . . . . . . . . . . . 86

3.8. Sobór Watykański ı. Maryja chrysto- i eklezjotypiczna . . . . . . . . 88

3.9. W kierunku mariologii integralnej i interdyscyplinarnej . . . . . . . . 90

IV Maryjne prawdy . . . . . . . . . . . . . . . . . . . . . . . 97

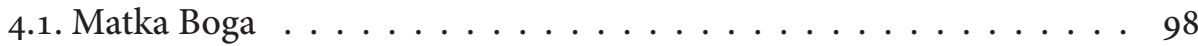

4.1.1. Rozwój rozumienia macierzyństwa Bożego . . . . . . . . . . . . . . . . 99

4.1.2. Matka Boga-Człowieka . . . . . . . . . . . . . . . . 100

4.1.3. Sens macierzyństwa Bożego. . . . . . . . . . . . . . . 104

4.2. Zawsze Dziewica . . . . . . . . . . . . . . . . . . . . . . . . . . . . . . . . . . . . . . . . . . . . . .

4.2.1. Przekaz doktrynalny . . . . . . . . . . . . . . . . . . . . . . . . . . . . . . . . . . . . . .

4.2.2. Wymowa teologiczna . . . . . . . . . . . . . 112

4.2.3. Dziewictwo Maryi w kategorii znaku . . . . . . . . . . . . . . 113

4.2.4. Kategoria dziewictwa - współczesne rozumienie . . . . . . . . 115

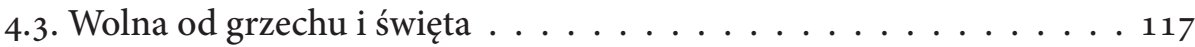

4.3.1. Zarys historii . . . . . . . . . . . . . . . . . . . . . . . . . . . . . . . . . . .

4.3.2. Teologia doktryny . . . . . . . . . . . . . . 118

4.4. Niepokalanie Poczęta . . . . . . . . . . . . . . . . . . 120

4.4.1. Rozwój wiedzy o niepokalanym poczęciu . . . . . . . . . . 121

4.4.2. Treść dogmatyczna . . . . . . . . . . . . . . . . . . . . . . . . . . . . . . . . . . . . . . . . . . .

4.4 .3 . Wartość dogmatu . . . . . . . . . . . . . . . . . . . . . . . . . . . . . . . . . . . . . . . .

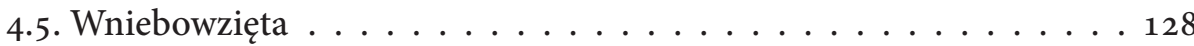

4.5.1. Rozwój rozumienia wiary . . . . . . . . . . . . . . . . 129

4.5.2. Dogmat . . . . . . . . . . . . . . . . . . . . . . . . . . . . . . . . . . .

4.5.3. Czy Maryja doznała fizycznej śmierci? . . . . . . . . . . . . . . 133

4.5.4. Przywilej tylko Maryi? . . . . . . . . . . . . . . . . . 136

v Jedność Maryi z Duchem Świętym . . . . . . . . . . . . . . . . . . . . . . . . . . 139

5.1. Biblijne przesłanki: Maryja i Duch Święty . . . . . . . . . . . . . . . . 139

5.1.1. Poczęcie Syna Najwyższego przez Maryję w Duchu Bożym . . . 140

5.1.2. Charyzmaty służebne Maryi . . . . . . . . . . . . . . . . . 141

5.1.3. Modlitwa Maryi: owoc Ducha Świętego . . . . . . . . . . . . . . 142

5.2. Jedność Maryi z Duchem Trójjedynego Boga . . . . . . . . . . . . . 144

5.2.1. Niepokalane poczęcie . . . . . . . . . . . . . . . . . 145

5.2.2. Wcielenie Syna Bożego . . . . . . . . . . . . . . . . . . . . . . . . . . . . . . . . . . . . .

5.2.3. Boże macierzyństwo . . . . . . . . . . . . . . . . . . 146

5.2.4. Uczestnictwo Maryi w dziełach zbawczych . . . . . . . . . . . 147

5.3. Formy i sposoby jedności Maryi z Duchem Boga . . . . . . . . . 150 
vi Maryja w dziele odkupienia . . . . . . . . . . . . . . . . . . 153

6.1. Współdziałanie . . . . . . . . . . . . . . . . . . . . 154

6.1.1. Łączność Maryi z Odkupicielem . . . . . . . . . . . . . 156

6.1.2. Odkupienie i udział Maryi . . . . . . . . . . . . . . . . . . . . . . . . . . . . . . . . . . . . . .

6.1.3. Dowodzenie teologiczne. . . . . . . . . . . . . 158

6.2. Pośrednictwo. . . . . . . . . . . . . . . . . . . . 159

6.2.1. Stanowisko Magisterium . . . . . . . . . . . . . . . . . 159

6.2.2. Nowe modele pośrednictwa . . . . . . . . . . . . . 161

6.3. Macierzyństwo duchowe . . . . . . . . . . . . . . . . . . 165

6.4. Maryja a Kościół . . . . . . . . . . . . . . . . . 166

6.4.1. Maryja: członek Kościoła . . . . . . . . . . . . . . . . . . . 167

6.4.2. Maryja jako typ Kościoła . . . . . . . . . . . . . . . . 168

6.4.3. Maryja Matką Kościoła . . . . . . . . . . . . . . . . 170

vir Celebracja Maryi w Kościele . . . . . . . . . . . . . . . . . . . 173

7.1. Z dziejów maryjnej pobożności . . . . . . . . . . . . . . . 173

7.1.1. Epoka poapostolska i patrystyczna (I-v wiek). . . . . . . . . 174

7.1.2. Od soboru efeskiego do połowy średniowiecza (V-XI wiek) . . 175

7.1.3. Między XI a XVI wiekiem . . . . . . . . . . . . . . 176

7.1.4. Ruchy reformacyjne i Sobór Trydencki (1545-1563) . . . . . . 177

7.1.5. Maryjne szkoły duchowości w XVII i Xviı wieku . . . . . . . . . . 178

7.1.6. Apogeum kultu (1854-1950) . . . . . . . . . . . . . 180

7.1.7. Sobór Watykański ıI: reforma kultu maryjnego . . . . . . . . . . 182

7.2. Dlaczego należy czcić Maryję? . . . . . . . . . . . . . . . . . . . . . . . . . . . . . . . . . . . . . . . . .

7.3. Teologia kultu Maryi . . . . . . . . . . . . . . . . . . . . 186

7.3.1. Źródła kultu maryjnego . . . . . . . . . . . . . . . . . . . . . . . . . . . . . . . . . . . . . . .

7.3.1.1. Miejsca biblijne . . . . . . . . . . . . . . . . . . . . . . . . . . . . . . . . . . . .

7.3.1.2. Wiara Kościoła. . . . . . . . . . . . . . . . 193

7.4. Odnowa kultu maryjnego

w świetle Marialis cultus. . . . . . . . . . . . . . . . . . . . . . . . . . . . . . . . . . . . . . . . . .

7.4.1. Cztery zasady odnowy . . . . . . . . . . . . . . . . . 195

7.4.2. Drogi odnowy. . . . . . . . . . . . . . . . . . . . . . . . . . . . . . . . . . . . . . . . . .

7.5. Liturgiczne miejsca i sposoby kultu . . . . . . . . . . . . . . . . . . . . . . . . . . . . . . . . .

7.5.1. Uroczystości, święta i wspomnienia . . . . . . . . . . . . 198

7.5.2. Maryja w Ordo Missae . . . . . . . . . . . . . . . . . . . . . . . 199

7.5.3. Maryjne msze święte i nieszpory . . . . . . . . . . . . . . . 201

7.5.4. Lekcjonarz mszalny i liturgia godzin . . . . . . . . . . . . . . . . . . . . . . 202

7.6. Modlitewne formy czci . . . . . . . . . . . . . . . . . . . . . . . . . . . 203

7.6.1. Cztery modlitwy biblijne . . . . . . . . . . . . . 204

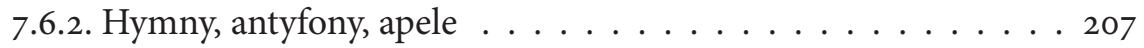

7.6.3. Litanie, tytuły i wezwania . . . . . . . . . . . . . 209 


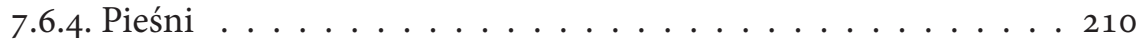

7.6.5. Akty zawierzenia . . . . . . . . . . . . . . . . . 212

7.6.6. Peregrynacje jasnogórskiego wizerunku . . . . . . . . . . 215

7.7. Przepowiadanie (homilie, kazania, katechezy) . . . . . . . . . . . 216

7.8. Maryjne sanktuaria i pielgrzymowanie . . . . . . . . . . . . . . . . . . . . . . . . . . . . . . . .

7.9. Kultura i sztuka o Maryi . . . . . . . . . . . . . . . . . . 219

7.10. Struktury naukowe . . . . . . . . . . . . . . . . . 219

7.10.1. Ośrodki naukowe i centra formacji . . . . . . . . . . . 220

7.10.2. Polskie Towarzystwo Mariologiczne . . . . . . . . . . . . . 220

VIII Artyzm i transcendencja maryjnych obrazów . . . . . . . . . . 223

8.1. Maryja i Jej piękno w ewangelizacji . . . . . . . . . . . . . . . . . . . . . . . . . . . . . . . .

8.2. Biblijny zakaz sporządzania obrazu? . . . . . . . . . . . 225

8.3. Z historii teologii świętego obrazu. . . . . . . . . . . . . . . 228

8.4. Wcielenie: chrystologiczny fundament maryjnej ikony . . . . . . . . 236

8.5. Typy ikon maryjnych . . . . . . . . . . . . . . . . . . 241

Ix Mariologia ekumeniczna . . . . . . . . . . . . . . . . . 243

9.1. Prawosławie i Przebłogosławiona . . . . . . . . . . . . . . 243

9.2. Ewangelicy a Matka Pana. . . . . . . . . . . . . . . . . . . . 246

9.3. Współczesny dialog chrześcijan . . . . . . . . . . . . . 250

9.4. Ekumeniczne rozstaje i zbliżenia . . . . . . . . . . . . . 255

Podsumowanie . . . . . . . . . . . . . . . . . . . . . . . . . 259

Wykaz skrótów . . . . . . . . . . . . . . . . . . 263

Bibliografia . . . . . . . . . . . . . . . . . . 265 